


\title{
NOVEL ANTIMICROBIAL FILMS BASED ON ETHYLENE-VINYL ALCOHOL COPOLYMERS FOR FOOD PACKAGING APPLICATION
}

\section{Doctor of Philosophy}

\author{
Presented by: \\ Virginia Muriel Galet
}

Supervised by:

Dr. Rafael Gavara Clemente Dra. Pilar Hernández Muñoz 

Dr. Rafael Gavara Clemente, Profesor de Investigación del Instituto de Agroquímica y Tecnología de los Alimentos del Consejo Superior de Investigaciones Científicas y

Dra. Pilar Hernández Muñoz, Científica Titular del Instituto de Agroquímica y Tecnología de los Alimentos del Consejo Superior de Investigaciones Científicas.

Hacen constar que:

La memoria titulada "Novel antimicrobial films based on ethylene-vinyl alcohol copolymers for food packaging application" que presenta $D^{a}$ Virginia Muriel Galet para optar al grado de Doctor por la Universidad Politécnica de Valencia, ha sido realizada en el Instituto de Agroquímica y Tecnología de Alimentos (IATA-CSIC) bajo su dirección y que reúne las condiciones para ser defendida por su autora.

Valencia, 3 de noviembre 2014 

A mis padres,

Javier y Carmina 



\section{ACKNOWLEDGEMENTS}

Me gustaría expresar mis más sinceros agradecimientos a mis directores de Tesis, Dr. Rafael Gavara y Dra. Pilar Hernández por ofrecerme esta gran oportunidad. Muchas gracias por vuestras enseñanzas, dedicación, apoyo y sobre todo por vuestra cercanía, siempre me he sentido muy afortunada de formar parte de vuestro equipo. Agradezco también al Dr. Ramón Catalá todo su tiempo, ha sido un placer las conversaciones, y las orientaciones que he recibido.

Con especial cariño a la Dra. Gracia López Carballo por su tiempo y esfuerzo, por transmitirme toda su pasión y entusiasmo.

Gracias a "Goddard Research Group" y a todos mis compañeros de la Universidad de Massachusetts y al "Institute for Sustainability \& Innovation" de la Universidad de Victoria. Ha sido una experiencia inolvidable poder realizar estancias con vosotros.

A todos mis compañeros, los que estáis y los que ya os marchasteis, por vuestra acogida, disponibilidad, por compartir conmigo conocimientos y muy buenos momentos. A mis vecinas de laboratorio y a cada una de las personas de este centro que han compartido conmigo esta etapa de la vida.

Gracias a Pablo Lacruz por un trabajo de maquetación fabuloso.

A todos mis amigos por estar siempre ahí.

A mis hermanos, Darío y Adelaida, con los que siempre cuento. A Carlos, por el ánimo constante.

Por último y en especial, a mis padres, gracias por transmitirme vuestros valores y por enseñarme a luchar por aquello que merece la pena, por ser un ejemplo profesional y personal para mí. 



\section{TABLE OF CONTENTS}

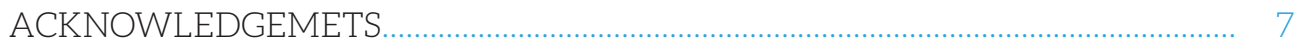

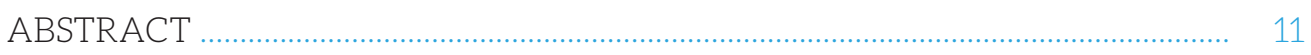

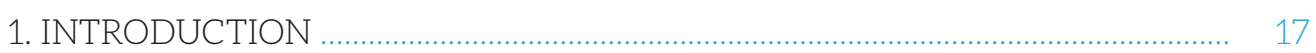

1.1. Antimicrobial active packaging ................................................................... 18

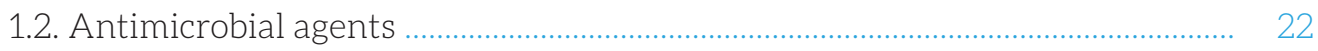

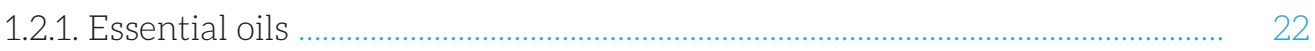

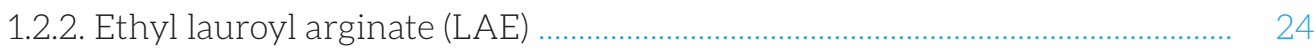



1.2.4. Green tea extract (GTE) ........................................................................... 25

1.2.5. Lysozyme ........................................................................................................ 26

1.3. Polymers used in antimicrobial active packaging ......................................... 27

1.3.1. Ethylene vinyl alcohol (EVOH) ........................................................... 28

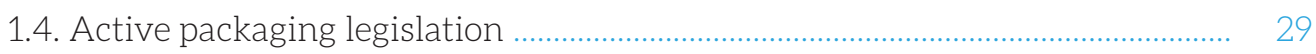

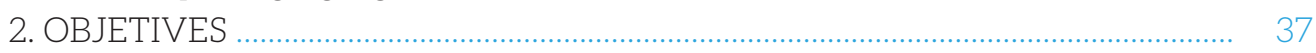

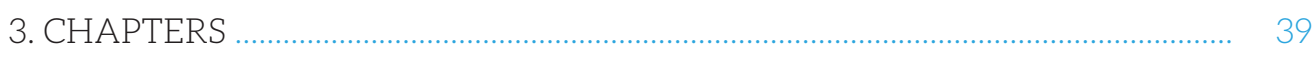

3.1. Chapter I .

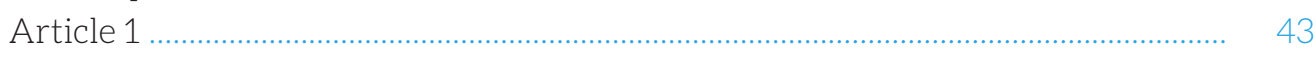

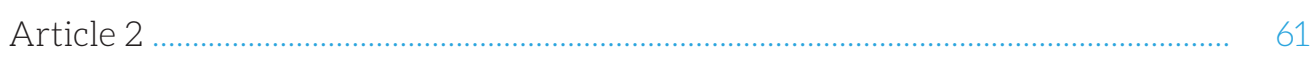



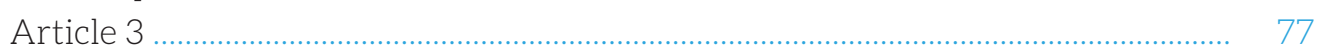

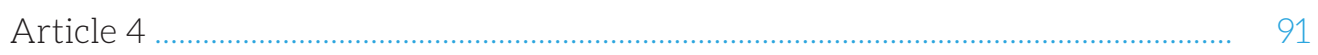

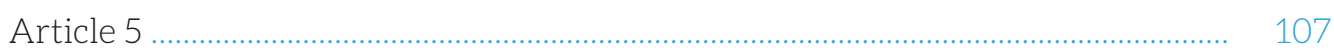

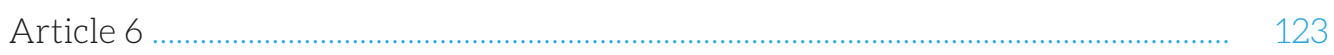

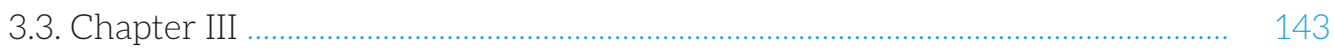

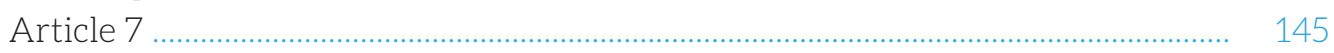

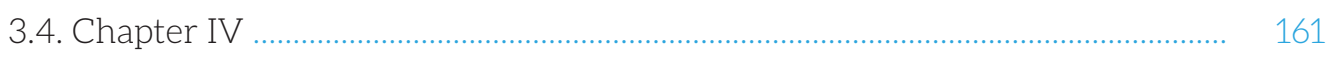

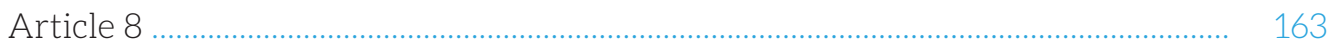

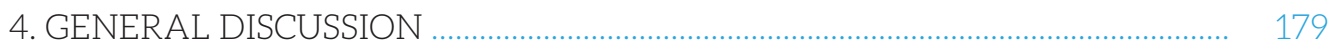

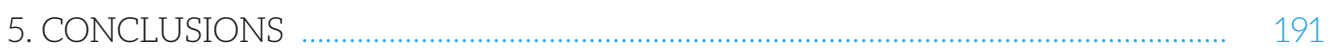





\section{ABSTRACT}

This PhD dissertation thesis has been focus on the development and characterization of antimicrobial packaging films based on the incorporation in the polymer matrix or on the attachment to the film surface of naturally occurring antimicrobial compounds with the purpose of inhibiting the proliferation of microorganisms and extend the microbiological shelf life of packaged food products.

The studied active films are based on the use of ethylene vinyl copolymers (EVOH) containing 29\% (EVOH29) or 44\% (EVOH44) molar percentage of ethylene as polymeric vehicle for the incorporation of several antimicrobial compounds -oregano essential oil (OEO), citral, ethyl lauroyl arginate (LAE), epsilon-polylysine (EPL), green tea extract (GTE) and lysozyme. These antimicrobial agents have been incorporated in the film-forming solution or immobilized to the film surface by covalent bonding.

Prior to the preparation of the active films, the antimicrobial activity of the selected compounds against selected microorganism was demonstrated, confirming that they could be good candidates to be used as preservatives for active food packaging applications, and an alternative to synthetic additives. The effect of the incorporation of the antimicrobial agents on relevant functional properties of the developed EVOH films was studied. In general, the polymer properties as materials for food packaging were not relevantly affected.

In order to evaluate the potential of EVOH matrices as sustain release systems of active compounds, the release kinetics of the active compounds from the film to different media was evaluated; for that the agent release rate and extend into food simulants was monitored, and it was concluded that the agent concentration, release temperature, type of $\mathrm{EVOH}$, interaction of $\mathrm{EVOH}$ with the food simulant, and the solubility of the active compound in the release media were the main controlling factors.

EVOH matrices have also shown good properties to be used for the attachment of active molecules. In this regard, lysozyme was successfully immobilized on the film surface of $\mathrm{EVOH}$.

Several experiments were conducted to determine the antimicrobial properties of the resulting films in vitro against different microorganisms responsible for foodborne illness and in vivo with real foods -minimally-process salad, infant milk, surimi sticks and chicken stock- to enhance their preservation. All the materials presented a strong in vitro antimicrobial activity. Although the results obtained through in vivo tests showed activity reductions caused by food matrix effects, all materials presented significant microbial inhibition and, therefore, great potential to be used in the design of active food packaging. They can be applied as an inner coating of the packaging structure, releasing the active agent or acting by direct contact, producing a great protection against contamination with a prolongation of the microbiological food shelf life. 



\section{RESUMEN}

En la presente tesis doctoral se han desarrollado y caracterizado películas antimicrobianas destinadas al envasado de alimentos, mediante la incorporación, en la matriz polimérica o anclaje a nivel superficial de compuestos antimicrobianos de origen natural, con el objetivo de inhibir la proliferación de microorganismos y extender la vida útil de los alimentos envasados.

En las películas activas desarrolladas, se ha utilizado el copolímero etileno-alcohol vinílico (EVOH), con 29\% (EVOH29) y 44\% (EVOH44) de contenido molar de etileno, como matriz polimérica para vehicular los compuestos antimicrobianos naturales seleccionados: aceite esencial de orégano (OEO), citral, etil lauroil arginato (LAE), epsilon polilisina (EPL), extracto de té verde (GTE) y lisozima. Estos agentes antimicrobianos han sido incorporados en la solución formadora de película o inmovilizados a nivel superficial mediante uniones covalentes.

Previa a la preparación de las películas activas, se ha estudiado la actividad antimicrobiana de los agentes naturales seleccionados frente a distintos microorganismos. Los resultados sugieren que son buenos candidatos para ser utilizados como aditivos naturales en materiales de envasado de alimentos, siendo una alternativa al uso de aditivos de origen sintético. También, se ha estudiado el efecto de la incorporación de dichos agentes en las propiedades funcionales de interés de los materiales desarrollados. En general, las propiedades de los polímeros necesarias para su aplicación, como envase alimentario, no se vieron afectadas de manera relevante.

Con el propósito de evaluar el potencial del copolímero EVOH, como matriz de liberación sostenida de los agentes antimicrobianos, se ha estudiado la cinética de liberación de dichos compuestos activos, desde las películas desarrollas a diferentes simulantes acuosos. Para ello, se ha determinado la tasa de liberación del agente en los simulantes alimentarios. Concluyendo que la concentración del agente antimicrobiano, la temperatura de liberación, el tipo de EVOH, las interacciones entre el copolímero EVOH y los simulantes, y la solubilidad del compuesto activo en el medio de liberación, fueron los principales factores a controlar.

Además, EVOH demostró que presenta propiedades idóneas para la modificación a nivel superficial con el posterior anclaje de moléculas activas. En este caso, moléculas de lisozima se inmovilizaron con éxito en la superficie de las películas.

Igualmente, se han realizado diferentes experimentos in vitro, para determinar las propiedades antimicrobianas de las películas obtenidas frente a diferentes microorganismos responsables de toxiinfecciones alimentarias, e in vivo con alimentos - ensaladas "IV Gama", leche infantil, palitos de cangrejo o surimi y caldo de pollo- con el objetivo de mejorar su conservación. Todos los materiales desarrollados presentaron una elevada capacidad antimicrobiana in vitro. Aunque los resultados obtenidos in vivo mostraron una menor actividad antimicrobiana, debido al efecto de la matriz alimentaria. 
Todos los materiales desarrollados presentan inhibición antimicrobiana significativa, y por tanto, un gran potencial para ser utilizados en el diseño de envasado activo. Estos pueden servir como recubrimiento interior de una estructura multicapa, liberando el agente activo o actuando por contacto directo. Este uso ofrece una gran protección frente la contaminación microbiológica y extiende la vida útil de los alimentos envasados. 


\section{RESUM}

En la present tesi doctoral s'han desenvolupat i caracteritzat pel-lícules antimicrobianes destinades a l'envasat d'aliments, mitjançant la incorporació, en la matriu polimèrica o l'ancoratge a nivell superficial de compostos antimicrobians d'origen natural, amb l'objectiu d'inhibir la proliferació de microorganismes i estendre la vida útil dels aliments envasats.

En les pel-lícules actives desenvolupades s'ha utilitzat el copolímer etilè - alcohol vinílic (EVOH), amb un 29 \% (EVOH29) i un 44 \% (EVOH44) de contingut molar d'etilè, com a matriu polimèrica per a vehicular els compostos antimicrobians naturals seleccionats: oli essencial d'orenga (OEO), citral, etil lauroil arginat (LAE), èpsilon polilisina (EPL), extracte de te verd (GTE) i lisozim. Aquests agents antimicrobians han estat incorporats a la solució formadora de pel-lícula o immobilitzats a nivell superficial mitjançant unions covalents.

Prèviament a la preparació de les pel-lícules actives, s'ha estudiat l'activitat antimicrobiana dels agents naturals seleccionats front a diferents microorganismes. Demostrant-se que són bons candidats per a ser utilitzats com a additius naturals en materials d'envasat d'aliments, essent una alternativa a l'ús d'additius d'origen sintètic. També s'ha estudiat l'efecte de la incorporació dels esmentats agents en les propietats funcionals d'interès dels materials desenvolupats. En general, les propietats dels polímers necessàries per a llur aplicació, com a envàs alimentari, no es veieren afectades de manera rellevant.

Amb el propòsit d'avaluar el potencial del copolímer EVOH com a matriu d'alliberament sostingut dels agents antimicrobians, s'ha estudiat la cinètica d'alliberament dels esmentats compostos actius, des de les pel-lícules desenvolupades a diferents simulants aquosos. Per a fer-ho, s'ha determinat la taxa d'alliberament de l'agent als simulants alimentaris. Concloent que la concentració de l'agent antimicrobià, la temperatura d'alliberament, el tipus d'EVOH, les interaccions entre el copolímer EVOH i els simulants, i la solubilitat del compost actiu en el medi d'alliberament foren els principals factors a controlar.

A més a més, l'EVOH demostrà que presenta propietats idònies per a la modificació a nivell superficial amb el posterior ancoratge de molècules actives. En aquest cas, molècules de lisozim foren immobilitzades amb èxit en la superfície de les pel-lícules.

Igualment, es realitzaren diferents experiments in vitro, per a determinar les propietats antimicrobianes de les pel-lícules obtingudes front a diferents microorganismes responsables de toxiinfeccions alimentaries, i in vivo amb aliments - amanides "IV Gamma", llet infantil, palets de cranc o surimi, i brou de pollastre - per a millorar llur conservació. Tots els materials desenvolupats presentaren una elevada capacitat antimicrobiana in vitro. Encara que els resultats obtinguts in vivo mostraren una menor activitat antimicrobiana, degut a l'efecte de la matriu alimentària, tots els materials desenvolupats presenten una inhibició antimicrobiana significativa, i per tant, un gran potencial per a ser utilitzats en el disseny d'envasat actiu. Aquests poden ser utilitzats com a recobriment interior d'una 
estructura multicapa, alliberant l'agent actiu o actuant per contacte directe, oferint una gran protecció front a la contaminació microbiològica i estenent la vida útil dels aliments envasats. 


\section{INTRODUCTION}

Consumption of healthy, natural foods has increased and become very popular during recent years. However, many of these food products are perishable and require protection from spoilage during their preparation, storage and distribution. They may undergo faster deterioration as a result of physical, chemical and biological processes, including microbial contamination, which is mostly caused by bacteria, yeasts and moulds as a result of a low amount or lack of additives. The intrinsic microbial load of food is also closely related with the production of undesirable effects in foodstuffs, such as changes in odour, colour, taste, texture, etc. These kinds of changes lead to a reduction in shelf life which decreases the safety of food and threatens the security of public health. Shelf life can be defined as the time during which the food product remains safe, preserves sensory properties and chemical, physical and microbiological characteristics, and complies with any label declaration of nutritional data, when stored under the recommended conditions [1].

In addition, new risks related with foodborne outbreaks are being encountered because of changes in food production practices and in the environment, the increase in the global trade of food and changes to the genetic characteristics of the relevant pathogenic microorganisms [2]. Within the group of bacterial pathogens responsible for most foodborne infections, Salmonella, Listeria monocytogenes and Escherichia coli O157 can be highlighted. According to a scientific report of the European Food Safety Authority (EFSA) [3], Salmonella infection is the second most commonly reported foodborne disease in humans. The food safety criteria (absence in $25 \mathrm{~g}$ ) apply to products placed on the market during their shelf life. A decrease in case numbers has been observed in recent years in comparison with the past, but cases of salmonellosis are still detected in the European Union (EU), principally in meat and meat products. L. monocytogenes can contaminate a wide range of different foodstuffs, and, although cooking at temperatures higher than $65^{\circ} \mathrm{C}$ can destroy it, this bacteria is known to multiply at refrigeration temperatures or even lower [4] and can survive pasteurization [5, 6]. Consequently, L. monocytogenes can be found in ready-to-eat foods with a relatively long shelf life. The number of cases of human listeriosis has also decreased compared to the last 10 years. By contrast, foodborne illness produced by E. coli $\mathrm{O} 157$ has increased; this human infection is acquired through consumption of contaminated food or water by cross-contamination.

As a consequence, one of the food industry's main objectives is to produce safe, highquality food products with a longer shelf life, and to develop innovative food preservation technologies capable of avoiding foodborne diseases without compromising product quality and freshness, thus ensuring a safer global food supply [7].

Traditionally, antimicrobial agents have been added directly to food products to extend their shelf life. However, this method is not always effective because of the possible interactions and chemical reactions produced by additives or ingredients during food processing. Moreover, the concentrations of the active agents may decrease owing to their diffusion into the food matrix and an excessive amount of additives is needed in order to achieve the antimicrobial effect, with the corresponding risk of modifying the organo- 
leptic properties of the food [8, 9]. To avoid using an excessive amount of antimicrobial agent, one option is the use of sprays or dips to deliver the compound to the food surface. However, this method has some drawbacks, such as (i) it involves an additional manufacturing step, (ii) it may be disorganized, and (iii) loss of effectiveness of the dip on the surface may occur owing to diffusion of the antimicrobial compound into the interior of the food over time [10]. The use of packaging materials as carriers for various active substances, including antimicrobial compounds, is a promising option to avoid microbial contamination of foods, and preserve them from deterioration processes. In this sense, active films can ensure a sustained release of the antimicrobial to the food surface or headspace of the package during the storage of the product.

Hitherto, the primary functions of a food package are to contain the product, protect it against physical and environmental damage and provide information [11]. However, in recent decades the concept of Active Packaging has advanced in science to satisfy the demand for safe, high-quality food products. Active packaging is defined as a system in which the product/package/environment interacts to maintain the safety and quality of the product and to prolong its shelf life [12]. Various active packaging technologies have been developed in the last decade, such as moisture-control packaging, oxygen and carbon dioxide scavengers, polymer films with selective gas permeability, microwave susceptors and antimicrobial packaging.

The main objective of this Doctoral Thesis was to develop antimicrobial active films based on ethylene vinyl alcohol copolymer (EVOH) with antimicrobial compounds and to characterize their functional properties and, especially, their antimicrobial activity in vitro and in vivo in liquid and solid food systems against different bacteria.

\subsection{Antimicrobial active packaging}

Antimicrobial active packaging is defined as a packaging system that interacts with the food product or the surrounding headspace either to kill microorganisms that might be present in the food product or to inhibit their growth $[13,14]$. Antimicrobial packaging can offer slow, continuous migration of the agent from the packaging material to the food or the headspace of the package so that an adequate concentration of the antimicrobial agent is maintained over the shelf life period of the product [15].

There are basically two methodologies for producing antimicrobial packaging systems: a) the addition of an independent device, such as a sachet, pad or label containing the antimicrobial agent, which is separate from the food product and is included with the food in a conventional package. The release of the antimicrobial from the devices is triggered by different stimuli such as moisture generated by product with high or intermediate water activity, or due to an increment in the storage temperature, pH, etc.; and b) the use of antimicrobial materials incorporated during the manufacture of the package, that is, the antimicrobial agent is incorporated in a layer of a multilaminate structure; the active agent exerts its action by direct contact of the wall package with the food or via its release from the wall of the package to the food or headspace.

At present, the second methodology is the preferred alternative because the presence of an extraneous object inside the food package could be accidentally ingested or possibly be confused with a new sauce, sticker, toy or discount card misleading the function of the 
incorporated device. Any antimicrobial agent deliberately added to a packaging system to exert antimicrobial activity through its release into the food product must be nontoxic to human health, and this aspect is controlled by a number of regulatory agencies. There are several manufacturing techniques for incorporating antimicrobial agents into the walls of a packaging system. Then can basically be divided into two procedures:

a) Addition of agents that are intended to be released.

b) Immobilization of agents in the package wall with no agent release.

The selection should be based on the type of polymer, the characteristics of the antimicrobial agent, and especially the mechanism of action of the agent and the type of food $[7,9]$.

\section{a) Antimicrobial systems based on the release of the active agent.}

In these systems, the antimicrobial compound inhibits microbial growth via its release from the polymeric material onto the food surface or into the surrounding headspace. The antimicrobial agent is mixed with the polymer either by dissolution in a common solvent system from which the film is formed or by melt blending of the agent within the barrel of an extrusion machine or equivalent device. In both cases the active compound is distributed in the polymer matrix, homogeneously when polymer and agent are chemically compatible, or heterogeneously, forming a multiphase matrix in which sites enriched with the agent can be distinguished. The steps involved in the release of the agent from the polymer matrix comprise diffusion to the surface of the matrix and partition in the interface between the matrix and the food or the headspace. The mechanism of action differs, depending on the volatility of the agent:

1) Volatile compounds. They can be incorporated directly into the polymer solution if they are compatible, and an active film or structure can be obtained by evaporation of the solvent. Depending on the volatility of the agent, the drying process may result in considerable agent loss, limiting the efficiency of the incorporation procedure. Alternatively, the compound can be incorporated by melt blending in a mechanicalthermal process such as extrusion. In this case, the agent is heated to polymer melting temperature, with potential losses by both degradation and evaporation during film cooling. Whichever procedure is used, the final polymer film acts as a reservoir for the antimicrobial agents that will be released to the headspace and from the headspace to the food product, primarily during storage. The volatility of the compound, and its solubility in the food system and the package walls determine the calculation of the concentration of the compound in the food, which should always be higher than the minimum inhibitory concentration (MIC), defined as the lowest concentration required to produce visible inhibition in the growth of microorganisms [16]. Controlled delivery of the volatile is desirable to reach the right concentration during the product's shelf life, and restriction of release before packaging is advisable in order to reduce exhaustion of activity during film storage. The use of volatile antimicrobial agents is especially recommended for irregularly-shaped solid foods that cannot be vacuum packaged, that is, where good contact between food and packaging material is not possible (Figure 1). 
$\mathrm{SO}_{2}$, essential oils, natural herbs and spice extracts are some of the antimicrobial agents widely used. $\mathrm{SO}_{2}$ is commonly used as an antifungal to extend the shelf life of postharvest foods such as fruit and vegetables [17-19]. Essential oils or their components, such as thymol from oregano essential oil or cinnamaldehyde from cinnamon bark essential oil, have been widely incorporated in many different matrices, either biodegradable (zein [20]) or synthetic (polypropylene [21]). Cinnamaldehyde has been incorporated in gliadin films to extend the shelf life of bread and cream cheese [22, 23].

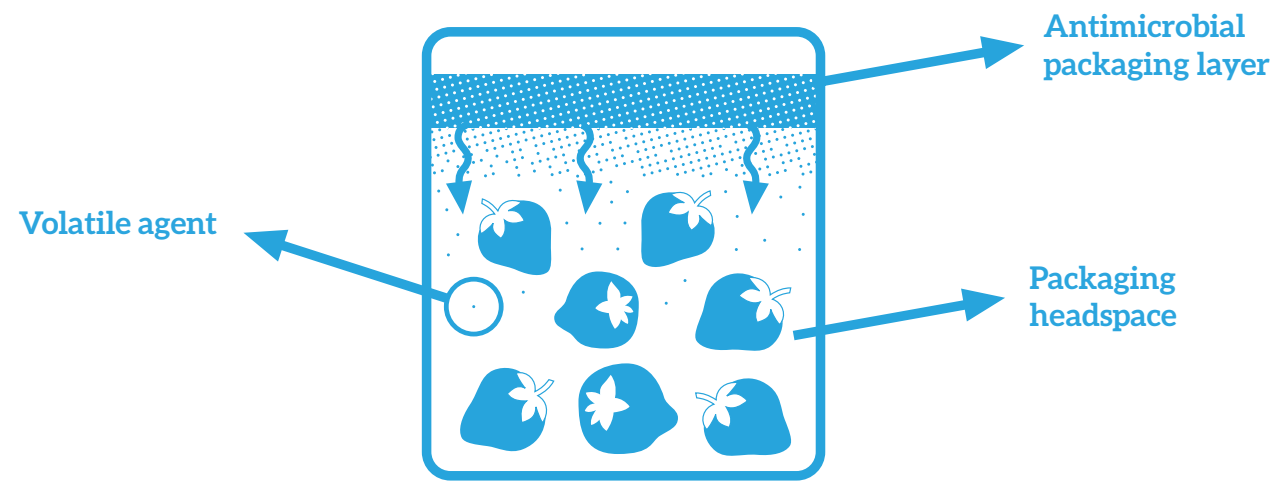

Figure 1. Antimicrobial packaging with volatile agent

2) Non-volatile compounds. As with volatile compounds, non-volatile agents can be incorporated either by mixing into the film-forming solution or by melt blending during extrusion procedures. The non-volatility of the compound reduces the loss during processing, despite the possibility of degradation due to interaction with the polymer matrix or to the temperature required for film manufacture. The main difference with respect to the previous group of agents is that, because of their non-volatility, direct interface contact between the active film and the food is required for release and, therefore, for any antimicrobial effect on the packaged product. Again, for the activity to be efficient, the non-volatile compound concentration in the food portion where the action is required should be higher than the minimum inhibitory concentration (MIC) during the product's shelf life. Non-volatile compounds are transported directly from the packaging materials to the food surface and by diffusion to the food matrix, and their use is effective for semi-solid or liquid foods where there is excellent food/ package contact and the antimicrobial is quickly distributed in the food, exerting its action on the whole product (Figure 2).

Organic acids and their salts, enzymes, bacteriocins, natural extracts, etc. have been used as antimicrobial compounds in packaging applications. For example, natamycin, a strong antifungal compound, has been incorporated in various biopolymers [24, 25], and nisin, a polypeptide produced by Lactococcus lactis, has been widely used in packaging films [26-28].

Volatile and non-volatile antimicrobial agents can be homogeneously distributed into the polymer package wall or concentrated in an "active layer", which can be positioned as the innermost layer, that is, in direct contact with the food, or sandwiched between passive barriers that modify the extent and kinetics of release of the compounds. Knowledge of the extent and kinetics of food/packaging interactions and adequate characterization are essential prerequisites for the design of the right structure which will deliver the 


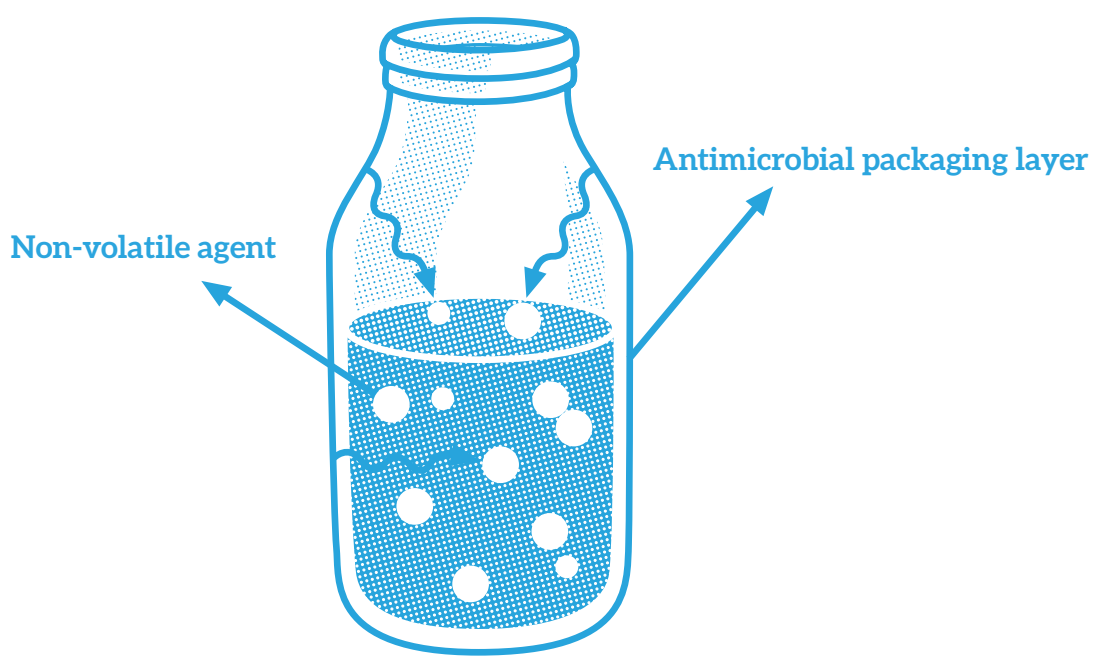

Figure 2. Antimicrobial packaging with a non-volatile agent

agent at a suitable rate and concentration, and will limit the interaction of undesired components.

\section{b) Immobilization of the antimicrobial agent on the surface of the polymer film}

Antimicrobial agents can be immobilized on the polymer surface of the package, exerting their antimicrobial activity by direct contact with the food product, or, more specifically, with the target microorganisms. This technology presents the advantage over the other technology that avoids the ingestion of the antimicrobial agent because they do not migrate to the food. Since the agents do not migrate, their activity is limited to the contact surface only (Figure 3). Immobilization of the antimicrobial has been used to create antimicrobial surfaces and it is convenient in the packaging of liquid foods where a good contact with the food is ensured, however, in solid or semi-solid foods, their activity is restricted to the area of contact between the packaging system and the food, and therefore their application is limited to vacuum packaging and/or the manufacture of slice separators.

Peptide antimicrobials are among the agents commonly immobilized on film surfaces, especially bacteriocins such as nisin and enzymes such as lysozyme. However, the immobilization of these substances on conventional polyolefin films presents some difficulties. Their low surface energy, which results in poor printability and coating properties, is also responsible for their low bonding capacity with antimicrobial agents. To improve these functional characteristics, various surface treatment techniques have been attempted: wet chemical treatment with strong acids and bases; oxidation or ionization with ozone, corona and flame discharge, UV irradiation, ion and electron beam irradiation and plasma exposure [29-31]. These techniques can introduce reactive functional groups for subsequent covalent attachment of a specific compound to the functionalized polymer surface. The quantity or surface density of the groups generated normally depends on the time and severity of the treatment. 


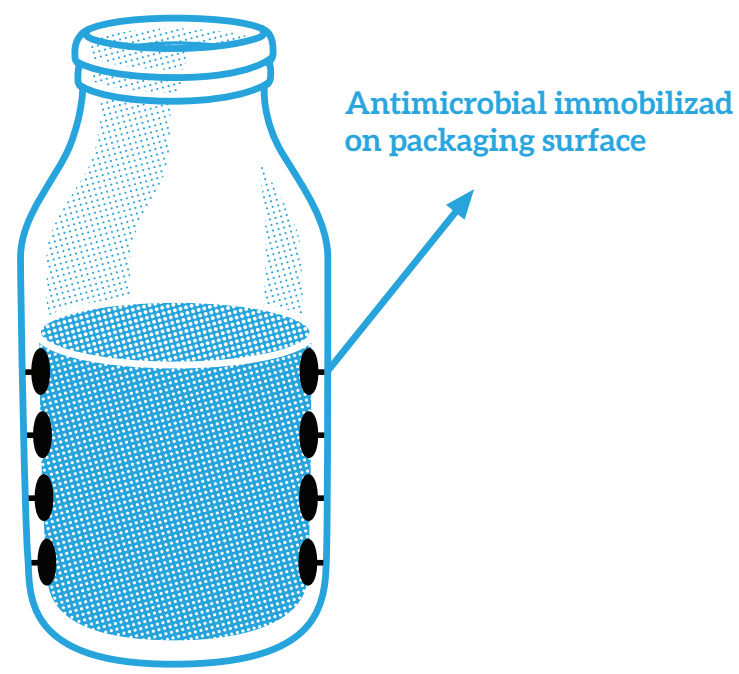

Figure 3. Antimicrobial packaging with the agent immobilized on the surface

\subsection{Antimicrobial agents}

The use of antimicrobial agents in food packaging can be another hurdle in the control of the microbial population to provide food products with higher safety and quality. Synthetic chemical preservatives have been widely incorporated in food packaging to control microbial growth, but at present most efforts are focused on the use of natural antimicrobial agents because of consumer demand to minimize chemical additives in food and the potential health risks derived from them. The selection of antimicrobial agents depends on their activity against target microorganisms, their compatibility with the packaging material and their stability during processing.

Various natural compounds are proposed as antimicrobial agents in this Doctoral Thesis: oregano essential oil (OEO), citral, ethyl lauroyl arginate (LAE), epsilon-polylysine (EPL), green tea extract (GTE) and lysozyme.

\subsubsection{Essential oils}

Essential oils (EOs) are aromatic liquids obtained from plant materials (flowers, buds, seeds, leaves, etc.). Steam distillation is the most common commercial method for extracting EOs without loss of their properties. It is well known that EOs of spices and plants have antimicrobial effects. The small terpenoids and phenolic compounds found in their chemical composition appear to be responsible for their antimicrobial activity [32], as the pure compounds are able to decrease pathogenic bacteria counts in foods significantly [33]. The mode of action is considered to be disturbance of the cytoplasmic membrane, disrupting the proton motive force, electron flow and active transport, and/or coagulation of bacteria cell contents (Figure 4).

There is no general agreement in the literature regarding the antimicrobial activity of EOs against Gram-positive and Gram-negative bacteria. Most studies have concluded 


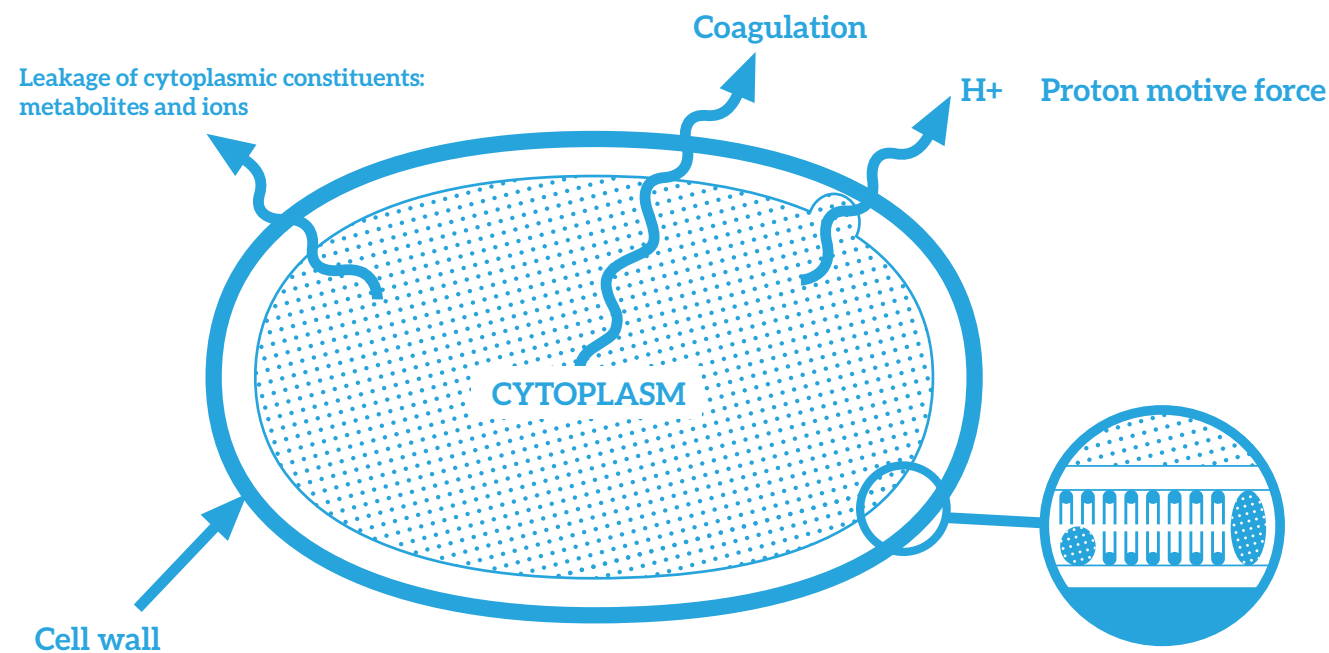

Figure 4. Site of action of essential oils

that Gram-positive bacteria are more susceptible. However, several studies report similar or stronger inhibiting action against Gram-negative bacteria [34, 35].

Oregano essential oil (OEO) is a natural antimicrobial agent classified as Generally Recognised as Safe (GRAS) by the Food and Drug Administration (FDA) and as a food additive by the European Union (EU). The chemical composition of OEO is complex and may vary, depending on the climate, season, etc. The most important constituent is carvacrol, representing 80\% of OEO, a volatile phenolic compound with strong antibacterial properties against pathogenic bacteria such as E. coli, L. monocytogenes, etc. and the initial load of spoilage microbes present in food products [33-38]. Carvacrol is able to interact with the cell membrane, producing distortion of the physical structure and destabilization of the membrane, increasing fluidity and passive permeability. It has been applied to extend the shelf life of various food products, and some studies have already included this volatile agent in a polymer matrix (Table 1).

Table 1. Carvacrol applications in packaging.

\begin{tabular}{ccc} 
& Material & Food products \\
\hline \multirow{3}{*}{ Carvacrol } & Edible films [39, 40] & Strawberries, chicken \\
\cline { 2 - 3 } & Starch-based film [41] & Cheddar cheese \\
\cline { 2 - 3 } & Chitosan films [42] & Rainbow trout \\
\hline
\end{tabular}

Lemongrass essential oil (LEO) is a natural antimicrobial agent classified as Generally Recognised as Safe (GRAS) by the Food and Drug Administration (FDA) and as a food additive by the European Union (EU). LEO has an assorted composition: Citral, the most abundant constituent, is a volatile mixture of two double-bound isomers (Figure 5) - neral, 32.2\%, and geranial, 41.28\% - and has a strong lemon flavour. The antimicrobial activity has been tested and showed antibacterial action against Gram-negative and Gram- 
positive organisms, yeast and mould [43-45]. Nevertheless, information regarding the antimicrobial activity of citral when it is incorporated in a film matrix is limited [46-48].

A



B

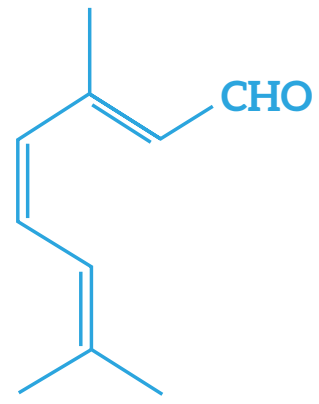

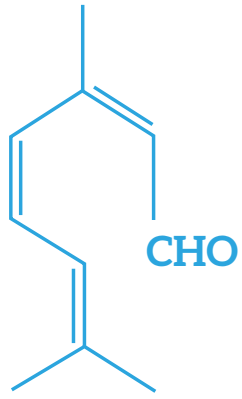

Figure 5. A) Chemical structure of carvacrol and B) Chemical structure of citral (neral and geranial)

\subsubsection{Ethyl lauroyl arginate (LAE)}

Ethyl lauroyl arginate (N-a-lauroyl-l-arginine ethyl ester monohydrochloride, LAE) is a cationic surfactant derived from lauric acid, L-arginine and ethanol, which is considered one of the most potent antimicrobial substances among novel food additives (Figure 6). It is a white powder soluble in water and stable between $\mathrm{pH} 3$ and 7.

The high antimicrobial activity of LAE has been attributed to its action on the cytoplasmic membranes of microorganisms, where it alters their metabolic processes without causing cellular lysis [49]. Furthermore, because of its low oil-water equilibrium partition coefficient, LAE tends to concentrate in the aqueous phase of products, where most bacterial action occurs $[50,51]$. LAE has been confirmed to be non-toxic and studies have demonstrated that LAE degrades to N-lauroyl-L-arginine (LAS), hydrolysis of which results in the production of arginine, which is converted to ornithine and urea, following acid catabolism via the urea and citric acid cycles, and excreted in urine [52].

LAE has been evaluated for food safety as antimicrobial in food and classified as GRAS by the Food and Drug Administration (FDA) and as a food preservative by the European Food Safety Authority (EFSA).

There is a small number of reports about the use of LAE in food packaging. LAE has been incorporated in PP and PET [53] and in chitosan film [54].

\subsubsection{Epsilon-polylysine (EPL)}

Epsilon-polylysine (EPL) was found in Japan by Shima and Sakai (1977). It is a natural antimicrobial compound produced from aerobic fermentation by Streptomyces albulus, a non-pathogenic microorganism [55]. The chemical composition is characterized by a cationic linear homopolymer compound of 25-35 residues of L-lysine connected between the $\varepsilon$-amino and $a$-carboxyl groups [56, 57] (Figure 7). EPL is highly soluble in water and has an isoelectric point of 9.0. Epsilon-polylysine resists hot water exposure, and can be 


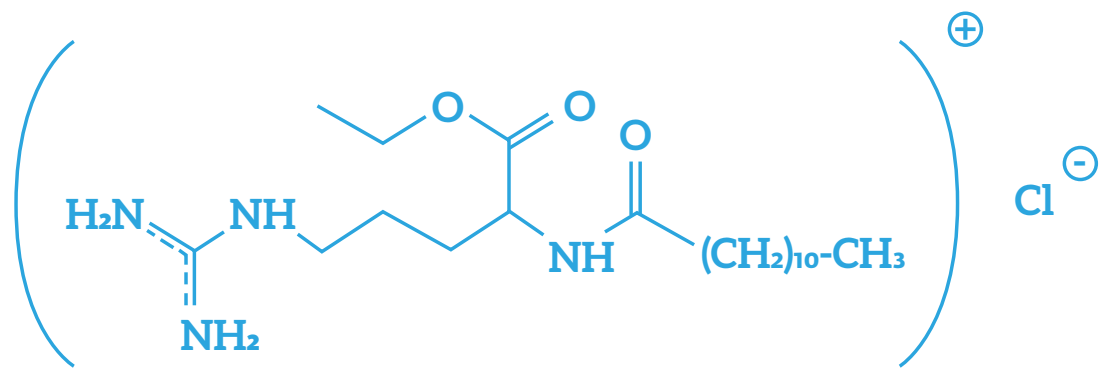

Figure 6. Chemical structure of LAE

boiled at $100{ }^{\circ} \mathrm{C}$ for 30 min or autoclaved at $120{ }^{\circ} \mathrm{C}$ for 20 min without degradation [58]. The antimicrobial action of EPL depends on the cationic property of the microorganism cell surface, with differences between bacteria, fungi and yeasts because of their surface composition. EPL is absorbed electrostatically onto the cell surface, leading to stripping of the outer membrane and producing abnormal distribution of cytoplasm [59].

The non-toxicity and safety of EPL has been demonstrated by experiments in rats. In Japan, EPL has been approved as a food additive at concentrations of 1000-5000 ppm for sliced fish or fish sushi and at concentrations of 10-500 ppm for the preservation of rice, soup and vegetables [60, 61]. In 2004, this compound was recognised as safe (GRAS) by the Food and Drug Administration (FDA) for use as an antimicrobial agent in cooked or sushi rice at levels up to $50 \mathrm{mg} / \mathrm{kg}$ of rice [62].

EPL has been widely used in the food industry as a food preservative [63, 64], emulsifying agent [65], etc. However, information about the incorporation of EPL in a polymer matrix is limited. Its antimicrobial properties have been studied in edible films [66, 67], and the effectiveness of whey protein films with EPL has been tested against beef spoilage microbiota [63].

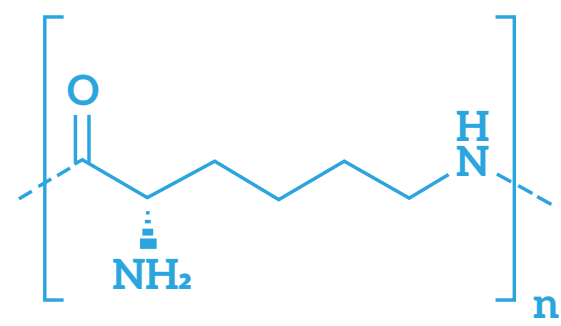

Figure 7. Epsilon-polylysine structure

\subsection{Green tea extract (GTE)}

Tea is a popular beverage, widely consumed by over two thirds of the world's population. Tea is made from the leaves of Camellia sinensis and undergoes different manufacturing processes to obtain green, oolong and black tea. 
In green tea production, the tea leaves retain their green colour and almost all of their original polyphenol content because they are processed with low fermentation, preventing catechin oxidation by polyphenol oxidases. Green tea has always been considered to have healthy properties, and its recognized beneficial effect has accelerated research on these properties. It is linked to lower incidence of various pathological conditions and has wellknown anti-inflammatory, anti-tumour, antioxidative and antimicrobial properties [68].

Green tea extract contains many different compounds which are responsible for its health-promoting properties. Its most interesting constituents are polyphenols, in particular catechins. Green tea contains four main catechins (and their respective isomers): epicatechin (EC), epicatechingallate (ECG), epigallocatechin (EGC), and epigallocatechingallate (EGCG). Caffeine, free amino acids, organic acids, mineral compounds, etc. are also found in it [69]. Catechins have strong antioxidant activities owing to their single electron reduction potential. They can act as antioxidants by donation of hydrogen atoms, as acceptors of free radicals, as interrupters of chain oxidation reactions, or by chelating metals [70, 71]. In addition, a number of studies have described their antimicrobial effects against foodborne pathogens, and the activity of green tea as an antimicrobial agent can be attributed to the low degree of fermentation $[68,69,72]$.

Green tea has been classified as a food additive by the European Union and has already been incorporated in food or in bioactive packaging systems in order to extend the shelf life of food products such as pork sausages and bread [73-75].

\subsubsection{Lysozyme}

Lysozyme was discovered by Alexander Fleming (1922). Lysozyme is an antimicrobial agent of natural origin present in many tissues and secretions, and is particularly abundant in egg white and many bivalve molluscs [76-80]. Its biological function is mainly defence from bacterial infection. Lysozyme derived from egg white was the first enzyme whose three-dimensional structure was determined and characterized [81] (Figure 8). It is characterized by a single polypeptide chain of 129 amino acids with a molecular weight of 14,307 Da and isoelectric point of 10.7.

The antimicrobial activity of lysozyme depend on its ability to hydrolyse the beta 1-4 glycosidic bonds between the N-acetylmuramic acid and $\mathrm{N}$-acetylglucosamine of the

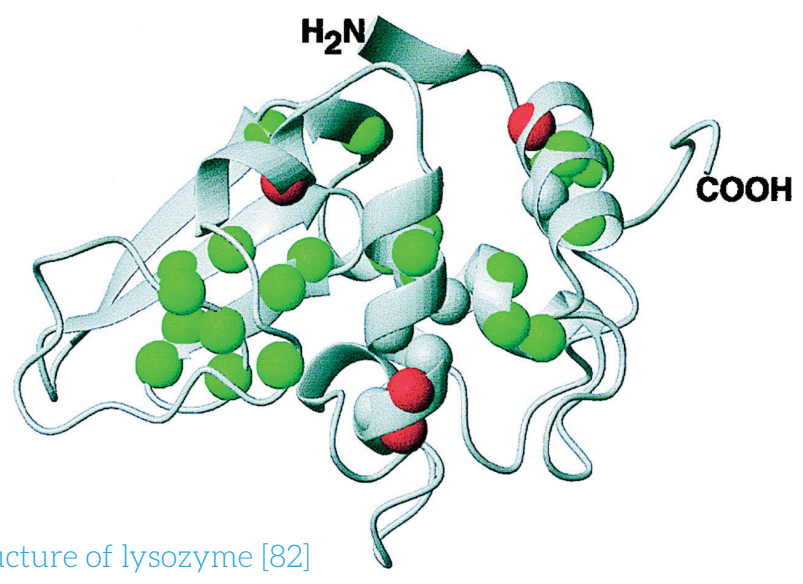

Figure 8. Chemical structure of lysozyme [82] 
peptidoglycan present in the bacterial cell wall. The chemical composition of the cell walls of Gram-positive bacteria differs from that of Gram-negative bacteria. The Grampositive cell wall is composed of peptidoglycan, which is freely accessible to the enzyme, whereas the Gram-negative cell wall is composed of two layers, an inner layer consisting of a single layer of peptidoglycan and an outer layer consisting of lipopolysaccharide. The outer layer of these bacteria impedes the action of lysozyme, making it less effective.

There are many factors that can affect the activity of lysozyme: $\mathrm{pH}$, temperature, ionic environment, the presence of electrolyte or ionic strength, and the accessibility of the bacterial cell wall.

Lysozyme has been classified as GRAS (Generally Recognized as Safe) by the Food and Drug Administration (FDA) and as a food additive by the European Union (E 1105). In the food industry it has been widely used as a food preservative, and it is one of the most studied natural antimicrobial agents, incorporated in various matrices for packaging applications (Table 2).

Table 2. Examples of lysozyme incorporated in food packaging materials.

\begin{tabular}{ccc} 
Matrix & Incorporation & Reference \\
\hline Polyvinyl alcohol (PVOH) & Surface immobilization & {$[83],[84]$} \\
& Film-forming solution & {$[85]$} \\
\hline Nylon & Surface immobilization & {$[83]$} \\
\hline Cellulose triacetate & Surface immobilization & {$[83]$} \\
\hline Soy protein & Film-forming solution & {$[86]$} \\
\hline Corn zein & Film-forming solution & {$[86],[87],[88]$} \\
\hline Chitosan & Film-forming solution & {$[89],[90],[91]$} \\
\hline Whey protein & Film-forming solution & {$[92]$} \\
\hline Polyethylene (PE) & Surface immobilization & {$[93]$} \\
\hline Carboxymethyl cellulose & Film-forming solution & {$[94]$} \\
\hline
\end{tabular}

\subsection{Polymers used in antimicrobial active packaging}

Various polymers have been studied as possible candidates for the incorporation of antimicrobial agents. Synthetic polymers derived from petroleum have been widely used to develop antimicrobial packaging, including low-density polyethylene (LDPE) [96, 97], polyvinyl alcohol (PVOH) [85, 98], polyethylene terephthalate (PET) [99, 100] and polypropylene (PP) $[21,101]$. They have a range of advantages that make them suitable for food applications, such as low cost, variable barrier properties, transparency, physical stability, etc.

In the present Doctoral Thesis, ethylene vinyl alcohol copolymers (EVOH) were chosen as polymer matrices to incorporate or attach various antimicrobial agents. 


\subsubsection{Ethylene vinyl alcohol (EVOH)}

Ethylene vinyl alcohol copolymers (EVOH) are a family of semi-crystalline copolymers of ethylene and vinyl alcohol. They are synthesized by polymerization of ethylene and vinyl acetate to provide the ethylene vinyl acetate (EVA) copolymer followed by hydrolysis. EVOH is heat-sealable, like many other semi-crystalline polymers, and its properties vary strongly with the mole \% of ethylene content. EVOH copolymers are commercialized with an ethylene mole \% in the 26 to $48 \%$ range (Figure 9).

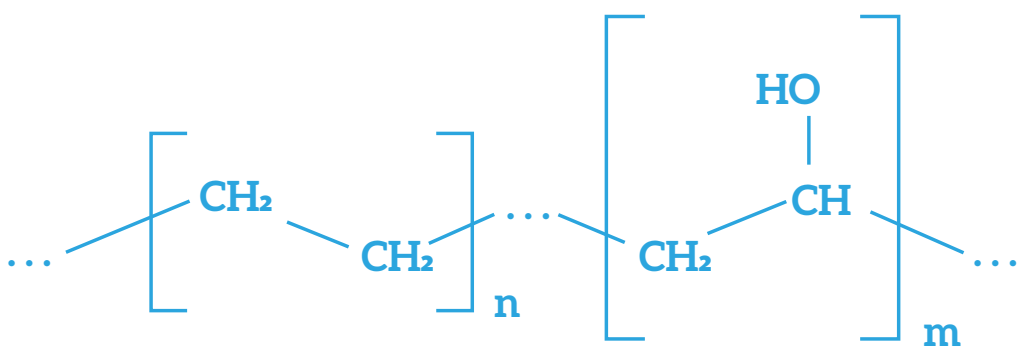

Figure 9. Chemical structure of EVOH

The EVOH matrix has the typical morphology of semicrystalline materials, with highly ordered crystalline structure regions interspersed with disordered amorphous regions. This morphology, together with the high interchain cohesion caused by hydrogen bonding, is responsible for its high resistance to the diffusion of gases and solvents.

Furthermore, it has excellent oxygen permeability and a highly hydrophilic nature [102]. Its gas barrier property is the main reason for its use in the design of packaging structures, especially for oxygen-sensitive products. Table 3 provides a comparison of the barrier properties of various polymers [103].

EVOH sorbs large amounts of water in the presence of humidity, resulting in plasticization of the polymer matrix and loss of barrier characteristics. To avoid this effect, EVOH is commonly sandwiched between two layers of hydrophobic materials.

Table 3. Oxygen permeability (OP) and Water Vapour Permeability (WVP) of various polymers

Material

OP

WVP

$\left(\mathrm{m}^{3} \cdot \mathrm{m} / \mathrm{m}\left(\mathrm{m}^{2} . \mathrm{s} \cdot \mathrm{Pa}\right)\right), 25^{\circ} \mathrm{C}$

(kg.m/(m².s.Pa)), $38^{\circ} \mathrm{C}$

\begin{tabular}{ccc}
\hline $\begin{array}{c}\text { Low-density polyethylene } \\
\text { (LDPE) }\end{array}$ & 420 & $1.0-1.5$ \\
\hline $\begin{array}{c}\text { Polyester } \\
\text { (PET) }\end{array}$ & $3-4$ & $1.0-1.3$ \\
\hline $\begin{array}{c}\text { Polypropylene } \\
\text { (PP) }\end{array}$ & 150 & 0.25 \\
\hline
\end{tabular}

Ethylene vinyl alcohol

(EVOH) 
Different multilayers containing EVOH as a barrier material are used to preserve food quality and flavour in convenient packaging. It has been very successful in the market because EVOH offers flexibility, transparency and a high barrier to gases, flavours and aromas, and its processability is similar to that of other polyolefins.

Water is the main problem for EVOH when a gas barrier is required, because these copolymers tend to sorb large amounts of water when exposed to humid environments; this water swells the polymers and disrupts interchain cohesion, and as a consequence the mechanical and, especially, barrier properties are severely damaged. This water sensitivity has recently been used in the development of active packages for food, because food humidity is a potential mechanism for triggering their activity [104-108]. In these applications, the active agent is added directly to the polymer matrix, and when the polymer is exposed to a humid environment (that is, the food packaging step) the release of the active compound starts. Moreover, EVOH provides a suitable chemistry for surface modification because of the presence of hydroxyl groups.

\subsection{Active packaging legislation}

As mentioned earlier, active food contact materials absorb or release substances in order to improve the quality of packaged food or to extend its shelf life. The safety of food contact materials requires evaluation because substances are deliberately added to migrate from these materials into the food. The materials should be manufactured in compliance with European Union (EU) regulations, including Good Manufacturing Practices (GMPs), so that any potential transfer to food does not present a hazard to human health, change the composition of the food in an unacceptable way or cause deterioration of its organoleptic characteristics. The general requirements for all food contact materials are laid down under the EU Framework Regulation EC 1935/2004 and are supported by Regulation EC 2023/2006 on Good Manufacturing Practice.

Regulation EC 450/2009 sets down specific requirements for the use and authorization of active and intelligent materials and articles intended to come into contact with food. The regulation also establishes an EU list of substances that can be used in the manufacture of these materials. Only substances that are regulated as food additives or food flavourings may be released into food. According to this Regulation, active and intelligent packaging may only be placed on the market if it is appropriate and effective for its intended purpose of use, and it has to be accompanied by a declaration of compliance and include consumer information at the retail stage, as set out in Article 3 of Regulation EC $1935 / 2004$.

Efforts towards harmonization are taking place and replacing the remaining national legislation with Community-level regulations, because some food contact materials may be specifically covered in the national legislation of member states and only partially by EU regulations [109].

As mentioned in the introductory description of the various antimicrobial compounds, all the agents used in this work are food additives and, in principle, they can be used in the manufacture of active packaging systems. 


\section{REFERENCES}

[1] D. Kilcast, P. Subramaniam, The stability and shelf-life of food. Woodhead Publishing Cambridge, 2000.

[2] A.H. Havelaar, S. Brul, A. de Jong, R. de Jonge, M.H. Zwietering, B.H. ter Kuile, Future challenges to microbial food safety, International Journal of Food Microbiology, 139 (2010) S79S94.

[3] The European Union Summary Report on Trends and Sources of Zoonoses, Zoonotic Agents and Foodborne Outbreaks in 2012, EFSA Journal 2014, 12(2):3547 ( 312pp).

[4] J.R. Junttila, S.I. Niemela, J. Hirn, Minimum growth temperatures of Listeria monocytogenes and non-haemolytic listeria, Journal of Applied Bacteriology, 65 (1988) 321-327.

[5] D.W. Fleming, S.L. Cochi, K.L. MacDonald, J. Brondum, P.S. Hayes, B.D. Plikaytis, M.B. Holmes, A. Audurier, C.V. Broome, A.L. Reingold, Pasteurized milk as a vehicle of infection in an outbreak of listeriosis, New England Journal of Medicine, 312 (1985) 404-407.

[6] J. Lovett, D.W. Francis, J.M. Hunt, Listeria monocytogenes in raw milk: detection, incidence, and pathogenicity, Journal of Food Protection, 50 (1987) 188-192.

[7] J.H. Han, Innovations in Food Packaging, (2013).

[8] S.Y. Sung, L.T. Sin, T.T. Tee, S.T. Bee, A.R. Rahmat, W. Rahman, A.C. Tan, M. Vikhraman, Antimicrobial agents for food packaging applications, Trends in Food Science \& Technology, 33 (2013) 110-123.

[9] P. Appendini, J.H. Hotchkiss, Review of antimicrobial food packaging, Innovative Food Science and Emerging Technologies, 3 (2002) 113-126.

[10] J. H. Han, Antimicrobial food packaging, Food Technology, 54 (2000) 56-65.

[11] K. Cooksey, Active packaging and the shelf life of foods. CCR Press, Boca Raton, Florida 2010.

[12] R. Catala, R. Gavara, Developments in active food packaging, Arbor-Ciencia Pensamiento Y Cultura, 168 (2001) 109-127.

[13] P. Suppakul, J. Miltz, K. Sonneveld, S.W. Bigger, Active packaging technologies with an emphasis on antimicrobial packaging and its applications, Journal of Food Science, 68 (2003) 408-420.

[14] P. Appendini, J. H. Hotchkiss, Review of antimicrobial food packaging, Innovative Food Science and Emerging Technologies, 3 (2002) 113-126.

[15] S. Quintavalla, L. Vicini, Antimicrobial food packaging in meat industry, Meat Science, 62 (2002) 373-380.

[16] K.A. Hammer, C.F. Carson, T.V. Riley, Antimicrobial activity of essential oils and other plant extracts, Journal of Applied Microbiology, 86 (1999) 985-990.

[17] X. Yu, W. Xu, D. Li, Effect of an Antimicrobial Packaging on Postharvest Quality of Sweet Cherry, in: D. Xi, G. Cai, Z.L. Wang, D. Gao (Eds.) Packaging Science and Technology, 2012, pp. 249-253.

[18] E. Candir, A.E. Ozdemir, U. Kamiloglu, E.M. Soylu, R. Dilbaz, D. Ustun, Modified atmosphere packaging and ethanol vapor to control decay of 'Red Globe' table grapes during storage, Postharvest Biology and Technology, 63 (2012) 98-106.

[19] D. Sivakumar, E. Arrebola, L. Korsten, Postharvest decay control and quality retention in litchi (cv. McLean's Red) by combined application of modified atmosphere packaging and antimicrobial agents, Crop Protection, 27 (2008) 1208-1214.

[20] M.A. Del Nobile, A. Conte, A.L. Incoronato, O. Panza, Antimicrobial efficacy and release kinetics of thymol from zein films, Journal of Food Engineering, 89 (2008) 57-63. 
[21] M. Ramos, A. Jimenez, M. Peltzer, M.C. Garrigos, Characterization and antimicrobial activity studies of polypropylene films with carvacrol and thymol for active packaging, Journal of Food Engineering, 109 (2012) 513-519.

[22] M. Pau Balaguer, G. Lopez-Carballo, R. Catala, R. Gavara, P. Hernandez-Munoz, Antifungal properties of gliadin films incorporating cinnamaldehyde and application in active food packaging of bread and cheese spread foodstuffs, International Journal of Food Microbiology, 166 (2013) 369-377.

[23] A. Perdones, M. Vargas, L. Atares, A. Chiralt, Physical, antioxidant and antimicrobial properties of chitosan-cinnamon leaf oil films as affected by oleic acid, Food Hydrocolloids, 36 (2014) 256-264.

[24] M.I. Tsiraki, I.N. Savvaidis, Citrus extract or natamycin treatments on "Tzatziki" - a traditional Greek salad, Food Chemistry, 142 (2014) 416-422.

[25] M.P. Balaguer, P. Fajardo, H. Gartner, J. Gomez-Estaca, R. Gavara, E. Almenar, M. Pilar Hernandez, Functional properties and antifungal activity of films based on gliadins containing cinnamaldehyde and natamycin, International Journal of Food Microbiology, 173 (2014) 62-71.

[26] M. Guo, T.Z. Jin, L. Wang, O.J. Scullen, C.H. Sommers, Antimicrobial films and coatings for inactivation of Listeria innocua on ready-to-eat deli turkey meat, Food Control, 40 (2014) 64-70.

[27] A.l. Storia, G. Mauriello, F. Villani, D. Ercolini, Coating-activation and antimicrobial efficacy of different polyethylene films with a nisin-based solution, Food and Bioprocess Technology, 6 (2013) 2770-2779

[28] M.N.W. Norhana, S.E. Poole, H.C. Deeth, G.A. Dykes, Effects of nisin, EDTA and salts of organic acids on Listeria monocytogenes, Salmonella and native microflora on fresh vacuum packaged shrimps stored at 4 degrees C, Food Microbiology, 31 (2012) 43-50.

[29] J.M. Goddard, J.H. Hotchkiss, Polymer surface modification for the attachment of bioactive compounds, Progress in Polymer Science, 32 (2007) 698-725.
[30] J.N. Talbert, J.M. Goddard, Enzymes on material surfaces, Colloids and Surfaces Biointerfaces, 93 (2012) 8-19.

[31] M.D. Steven, J.H. Hotchkiss, Covalent Immobilization of an Antimicrobial Peptide on Poly(ethylene) Film, Journal of Applied Polymer Science, 110 (2008) 2665-2670.

[32] I.M. Helander, H.L. Alakomi, K. Latva-Kala, T. Mattila-Sandholm, I. Pol, E.J. Smid, L.G.M. Gorris, A.v. Wright, Characterization of the action of selected essential oil components on Gramnegative bacteria, Journal of Agricultural and Food Chemistry, 46 (1998) 3590-3595.

[33] S. Burt, Essential oils: their antibacterial properties and potential applications in foods - a review, International Journal of Food Microbiology, 94 (2004) 223-253.

[34] S.G. Deans, G. Ritchie, Antibacterial properties of plant essential oils, International Journal of Food Microbiology, 5 (1987) 165-180.

[35] B. Ouattara, R.E. Simard, R.A. Holley, G.J.P. Piette, A. Begin, Antibacterial activity of selected fatty acids and essential oils against six meat spoilage organisms, International Journal of Food Microbiology, 37 (1997) 155-162.

[36] J. Gutierrez, C. Barry-Ryan, P. Bourke, The antimicrobial efficacy of plant essential oil combinations and interactions with food ingredients, International Journal of Food Microbiology, 124 (2008) 91-97.

[37] H.J.D. Dorman, S.G. Deans, Antimicrobial agents from plants: antibacterial activity of plant volatile oils, Journal of Applied Microbiology, 88 (2000) 308-316.

[38] M. Oussalah, S. Caillet, M. Lacroix, Mechanism of action of Spanish oregano, Chinese cinnamon, and savory essential oils against cell membranes and walls of Escherichia coli 0157:H7 and Listeria monocytogenes, Journal of Food Protection, 69 (2006) 1046-1055.

[39] G. Peretto, W.-X. Du, R.J. Avena-Bustillos, S.B.L. Sarreal, S.S.T. Hua, P. Sambo, T.H. McHugh, Increasing strawberry shelf-life with carvacrol and methyl cinnamate antimicrobial vapors released from edible films, Postharvest Biology and Technology, 89 (2014) 11-18. 
[40] W.-X. Du, R.J. Avena-Bustillos, R. Woods, A.P. Breksa, T.H. McHugh, M. Friedman, C.E. Levin, R. Mandrell, Sensory Evaluation of Baked Chicken Wrapped with Antimicrobial Apple and Tomato Edible Films Formulated with Cinnamaldehyde and Carvacrol, Journal of Agricultural and Food Chemistry, 60 (2012) 7799-7804.

[41] K.K. Kuorwel, M.J. Cran, K. Sonneveld, J. Miltz, S.W. Bigger, Evaluation of Antifungal Activity of Antimicrobial Agents on Cheddar Cheese, Packaging Technology and Science, 27 (2014) 49-58.

[42] V. Chamanara, B. Shabanpour, S. Gorgin, M. Khomeiri, An investigation on characteristics of rainbow trout coated using chitosan assisted with thyme essential oil, International Journal Biological Macromoleculas, 50 (2012) 540-544.

[43] H. Zhou, N. Tao, L. Jia, Antifungal activity of citral, octanal and alpha-terpineol against Geotrichum citri-aurantii, Food Control, 37 (2014) 277-283.

[44] F. Dubois-Brissonnet, M. Naitali, A.A. Mafu, R. Briandet, Induction of Fatty Acid Composition Modifications and Tolerance to Biocides in Salmonella enterica Serovar Typhimurium by Plant-Derived Terpenes, Applied and Environmental Microbiology, 77 (2011) 906-910.

[45] X.-W. Wang, H.-Y. Du, Y.-H. Song, Z.-S. Ma, Antimicrobial activity of oregano essential oil, carvacrol, citral and cinnamaldehyde, Food Science and Technology, 36 (2011) 193-202.

[46] X. Wang, H. Liu, J. Wei, Z. Ma, Effects of oregano oil, carvacrol, cinnamaldehyde, and citral on antimicrobial, mechanical and barrier properties of carrot puree films, Piageng 2010: Photonics and Imaging for Agricultural Engineering, 7752 (2010).

[47] N.F.F. Soares, W.A. Silva, E.A.A. Medeiros, R.T. Carelli, P.J.P. Espitia, Active packaging: New technologies for Shel-life extension, Italian Journal of Food Science, 23 (2011) 88-90.

[48] M. Maizura, A. Fazilah, M.H. Norziah, A.A. Karim, Antibacterial activity and mechanical properties of partially hydrolyzed sago starchalginate edible film containing lemongrass oil, Journal of Food Science, 72 (2007) C324-C330.
[49] E. Rodriguez, J. Seguer, X. Rocabayera, A. Manresa. Cellular effects of monohydrochloride of L-arginine, Nalpha-lauroyl ethylester (LAE) exposure on Salmonella Typhimurium and Staphylococcus aureus, Journal of Applied Microbiology, 96 (2004) 903-912.

[50] G. Bakal, A. Diaz, The lowdown on lauric arginate, Food Quality, (2005) 60-61.

[51] S.A. Ruckman, X. Rocabayera, J.F. Borzelleca, C.B. Sandusky, Toxicological and metabolic investigations of the safety of $\mathrm{N}$-alpha-lauroyll-arginine ethyl ester monohydrochloride (LAE), Food and Chemical Toxicology, 42 (2004) 245259.

[52] D.R. Hawkins, X. Rocabayera, S. Ruckman, R. Segret, D. Shaw, Metabolism and pharmacokinetics of ethyl N-alpha-lauroyl-L-arginate hydrochloride in human volunteers, Food and Chemical Toxicology, 47 (2009) 2711-2715.

[53] V. Otero, R. Becerril, J.A. Santos, J.M. Rodriguez-Calleja, C. Nerin, M.L. Garcia-Lopez, Evaluation of two antimicrobial packaging films against Escherichia coli 0157:H7 strains in vitro and during storage of a Spanish ripened sheep cheese (Zamorano), Food Control, 42 (2014) 296302.

[54] L. Higueras, G. Lopez-Carballo, P. Hernandez-Munoz, R. Gavara, M. Rollini, Development of a novel antimicrobial film based on chitosan with LAE (ethyl-N alpha-dodecanoyl-L-arginate) and its application to fresh chicken, International Journal of Food Microbiology, 165 (2013) 339-345.

[55] J. Hiraki, T. Ichikawa, S. Ninomiya, H. Seki, K. Uohama, S. Kimura, Y. Yanagimoto, J.W. Barnett, Use of ADME studies to confirm the safety of epsilon-polylysine as a preservative in food, Regulatory Toxicology and Pharmacology, 37 (2003) 328-340.

[56] S. Shima, H. Sakai, Polylysine produced by Streptomyces, Agricultural and Biological Chemistry, 41 (1977) 1807-1809.

[57] S. Shima, H. Matsuoka, T. Iwamoto, H. Sakai, Antimicrobial action of epsilon-poly-L-lysine Journal of Antibiotics, 37 (1984) 1449-1455. 
[58] J. Hiraki, $\varepsilon$-Polylysine, its development and utilization. Fine Chemistry, 29 (2000) 18-25.

[59] S. Shima, H. Matsuoka, T. Iwamoto, H. Sakai, Antimicrobial action of epsilon-poly-L-lysine. Journal of Antibiotics, 37 (1984) 1449-1455.

[60] J. Hiraki, Basic and applied studies on $\varepsilon$-polylysine, Journal Antibact Antifungal Agents 23 (1995) 349-493.

[61] J. Hiraki, $\varepsilon$-Polylysine, its development and utilization, Fine Chem 29 (2000) 18-25.

[62] FDA, Agency reponse letter GRAS Notice No. GRN 00135, 2004.

[63] K.G. Zinoviadou, K.P. Koutsoumanis, C.G. Biliaderis, Physical and thermo-mechanical properties of whey protein isolate films containing antimicrobials, and their effect against spoilage flora of fresh beef, Food Hydrocolloids, 24 (2010) 49-59.

[64] S.-S. Chang, W.-Y.W. Lu, S.-H. Park, D.-H. Kang, Control of foodborne pathogens on readyto-eat roast beef slurry by epsilon-polylysine, International Journal of Food Microbiology, 141 (2010) 236-241.

[65] Y. Chang, L. McLandsborough, D.J. McClements, Cationic Antimicrobial (epsilonPolylysine)-Anionic Polysaccharide (Pectin) Interactions: Influence of Polymer Charge on Physical Stability and Antimicrobial Efficacy, Journal of Agricultural and Food Chemistry, 60 (2012) 1837-1844.

[66] I.U. Unalan, K.D.A. Ucar, I. Arcan, F. Korel, A. Yemenicioglu, Antimicrobial Potential of Polylysine in Edible Films, Food Science and Technology Research, 17 (2011) 375-380.

[67] W. Wu-Yin, T. Zhong, L. Guang-Ming, S. Wen-Jin, O. Kazufumi, T. Munehiko, C. Min-Jie, Mechanical, barrier, optical properties and antimicrobial activity of edible films prepared from silver carp surimi incorporated with epsilonpolylysine, Packaging Technology and Science, 27 (2014) 37-47.

[68] S. Bansal, S. Choudhary, M. Sharma, S.S. Kumar, S. Lohan, V. Bhardwaj, N. Syan, S. Jyoti, Tea: A native source of antimicrobial agents, Food Research International, 53 (2013) 568-584.
[69] P.W. Taylor, J.M.T. Hamilton-Miller, P.D. Stapleton, Antimicrobial properties of green tea catechins, Food Science and Technology Bulletin: Functional Foods, 2 (2005) 71-81.

[70] V.K. Ananingsih, A. Sharma, W. Zhou, Green tea catechins during food processing and storage: A review on stability and detection, Food Research International, 50 (2013) 469-479.

[71] V. Chander, D. Singh, K. Chopra, Catechin, a natural antioxidant protects against rhabdomyolysis-induced myoglobinuric acute renal failure, Pharmacological Research, 48 (2003) 503-509.

[72] J. Oh, H. Jo, A.R. Cho, S.-J. Kim, J. Han, Antioxidant and antimicrobial activities of various leafy herbal teas, Food Control, 31 (2013) 403409.

[73] H.J. Kang, C. Jo, J.H. Kwon, J.H. Kim, H.J. Chung, M.W. Byun, Effect of a pectin-based edible coating containing green tea powder on the quality of irradiated pork patty, Food Control, 18 (2007) 430-435.

[74] L. Martinez, I. Cilla, J.A. Beltran, P. Roncales, Antioxidant effect of rosemary, borage, green tea, pu-erh tea and ascorbic acid on fresh pork sausages packaged in a modified atmosphere: Influence of the presence of sodium chloride, Journal of the Science of Food and Agriculture, 86 (2006) 1298-1307.

[75] W. Rong, Z. Weibiao, Y. Huei-Huei, C. Weng-Fai, Effects of green tea extract on the quality of bread made from unfrozen and frozen dough processes, Journal of the Science of Food and Agriculture, 86 (2006) 857-864.

[76] B. Masschalck, R. Van Houdt, E.G.R. Van Haver, C.W. Michiels, Inactivation of gram-negative bacteria by lysozyme, denatured lysozyme, and lysozyme-derived peptides under high hydrostatic pressure, Applied and Environmental Microbiology, 67 (2001) 339-344.

[77] A. Parisien, B. Allain, J. Zhang, R. Mandeville, C.Q. Lan, Novel alternatives to antibiotics: bacteriophages, bacterial cell wall hydrolases, and antimicrobial peptides, Journal of Applied Microbiology, 104 (2008) 1-13.

[78] J.P. Halper, N. Latovitz, H. Bernstei, S. Bey- 
chok, Optical activity of human lysozyme, Proceedings of the National Academy of Sciences of the United States of America, 68 (1971) 517.

[79] E.I. Elagamy, R. Ruppanner, A. Ismail, C.P. Champagne, R. Assaf, Purification and characterization of lactoferrin, lactoperoxidase, lysozyme and immunoglobulins from camel's milk, International Dairy Journal, 6 (1996) 129-145.

[80] S. Datta, M.E. Janes, Q.G. Xue, J. Losso, J.F. La Peyre, Control of Listeria monocytogenes and Salmonella anatum on the surface of smoked salmon coated with calcium alginate coating containing oyster lysozyme and nisin, Journal of Food Science, 73 (2008) M67-M71.

[81] C.C. Blake, D.F. Koenig, G.A. Mair, A.C. North, D.C. Phillips, V.R. Sarma, Structure of hen egg-white lysozyme. A three-dimensional Fourier synthesis at 2 Angstrom resolution, Nature 206 (1965) 757-761.

[82] T. Knubovets, J.J. Osterhout, P.J. Connolly, A.M. Klibanov, Structure, thermostability, and conformational flexibility of hen egg-white lysozyme dissolved in glycerol, Proceedings of the National Academy of Sciences of the United States of America, 96 (1999) 1262-1267.

[83] P. Appendini, J.H. Hotchkiss, Immobilization of lysozyme on food contact polymers as potential antimicrobial films, Packaging Technology \& Science, 10 (1997) 271-279.

[84] A. Conte, G.G. Buonocore, A. Bevilacqua, M. Sinigaglia, M.A. Del Nobile, Immobilization of lysozyme on polyvinylalcohol films for active packaging applications, Journal of Food Protection, 69 (2006) 866-870.

[85] G.G. Buonocore, A. Conte, M.R. Corbo, M. Sinigaglia, M.A. Del Nobile, Mono- and multilayer active films containing lysozyme as antimicrobial agent, Innovative Food Science \& Emerging Technologies, 6 (2005) 459-464.

[86] T. Padgett, I.Y. Han, P.L. Dawson, Incorporation of food-grade antimicrobial compounds into biodegradable packaging films, Journal of Food Protection, 61 (1998) 1330-1335.

[87] C. Mecitoglu, A. Yemenicioglu, A. Arslanoglu, Z.S. Elmaci, F. Korel, A.E. Cetin, Incorporation of partially purified hen egg white lysozyme into zein films for antimicrobial food packaging, Food Research International, 39 (2006) 12-21.

[88] I.U. Unalan, I. Arcan, F. Korel, A. Yemenicioglu, Application of active zein-based films with controlled release properties to control Listeria monocytogenes growth and lipid oxidation in fresh Kashar cheese, Innovative Food Science \& Emerging Technologies, 20 (2013) 208-214.

[89] S.I. Park, M.A. Daeschel, Y. Zhao, Functional properties of antimicrobial lysozyme-chitosan composite films, Journal of Food Science, 69 (2004) M215-M221.

[90] C.A. Brown, B.W. Wang, J.H. Oh, Antimicrobial activity of lactoferrin against foodborne pathogenic bacteria incorporated into edible chitosan film, Journal of Food Protection, 71 (2008) 319-324.

[91] M. Yuceer, C. Caner, Antimicrobial lysozyme-chitosan coatings affect functional properties and shelf life of chicken eggs during storage, Journal of the Science of Food and Agriculture, 94 (2014) 153-162.

[92] S. Min, L.J. Harris, J.M. Krochta, Antimicrobial effects of lactoferrin, lysozyme, and the lactoperoxidase system and edible whey protein films incorporating the lactoperoxidase system against Salmonella enterica and Escherichia coli O157 : H7, Journal of Food Science, 70 (2005) M332-M338.

[93] A. Conte, G.G. Buonocore, M. Sinigaglia, L.C. Lopez, P. Favia, R. D'Agostino, M.A. Del Nobile, Antimicrobial activity of immobilized lysozyme on plasma-treated polyethylene films, Journal of Food Protection, 71 (2008) 119-125.

[94] P. Mendes de Souza, A. Fernandez, G. Lopez-Carballo, R. Gavara, P. Hernandez-Munoz, Modified sodium caseinate films as releasing carriers of lysozyme, Food Hydrocolloids, 24 (2010) 300-306.

[95] A. Barbiroli, F. Bonomi, G. Capretti, S. Iametti, M. Manzoni, L. Piergiovanni, M. Rollini, Antimicrobial activity of lysozyme and lactoferrin incorporated in cellulose-based food packaging, Food Control, 26 (2012) 387-392.

[96] S.-Y. Sung, L.T. Sin, T.-T. Tee, S.-T. Bee, A.R. Rahmat, W.A.W.A. Rahman, Control of bacteria 
growth on ready-to-eat beef loaves by antimicrobial plastic packaging incorporated with garlic oil, Food Control, 39 (2014) 214-221.

[97] M. Jokar, R.A. Rahman, N.A. Ibrahim, L.C. Abdullah, C.P. Tan, Melt Production and Antimicrobial Efficiency of Low-Density Polyethylene (LDPE)-Silver Nanocomposite Film, Food and Bioprocess Technology, 5 (2012) 719-728.

[98] A.C. Valderrama Solano, C. de Rojas Gante, Two Different Processes to Obtain Antimicrobial Packaging Containing Natural Oils, Food and Bioprocess Technology, 5 (2012) 2522-2528.

[99] S. Manso, F. Cacho-Nerin, R. Becerril, C. Nerin, Combined analytical and microbiological tools to study the effect on Aspergillus flavus of cinnamon essential oil contained in food packaging, Food Control, 30 (2013) 370-378.

[100] N.P. Guerra, A.B. Araujo, A.M. Barrera, A.T. Agrasar, C.L. Macias, J. Carballo, L. Pastrana, Antimicrobial activity of nisin adsorbed to surfaces commonly used in the food industry, Journal of Food Protection, 68 (2005) 1012-1019.

[101] F. Licciardello, G. Muratore, P. Mercea, V. Tosa, C. Nerin, Diffusional Behaviour of Essential Oil Components in Active Packaging Polypropylene Films by Multiple Headspace Solid Phase Microextraction-Gas Chromatography, Packaging Technology and Science, 26 (2013) 173-185.

[102] S. Aucejo, R. Catala, R. Gavara, Interactions between water and EVOH food packaging films, Food Science and Technology International, 6 (2000) 159-164.

[103] J. Comyn, Polymer Permeability, Springer, 1985.

[104] J.P. Cerisuelo, V. Muriel-Galet, J.M. Bermudez, S. Aucejo, R. Catala, R. Gavara, P. Hernandez-Munoz, Mathematical model to describe the release of an antimicrobial agent from an active package constituted by carvacrol in a hydrophilic EVOH coating on a PP film, Journal of Food Engineering, 110 (2012) 26-37.

[105] C. Lopez de Dicastillo, C. Nerin, P. Alfaro, R. Catala, R. Gavara, P. Hernandez-Munoz, Development of new antioxidant active packaging films based on ethylene vinyl alcohol copolymer
$(\mathrm{EVOH})$ and green tea extract, Journal of Agricultural and Food Chemistry, 59 (2011) 7832 7840 .

[106] C. Lopez-de-Dicastillo, J.M. Alonso, R. Catala, R. Gavara, P. Hernandez-Munoz, Improving the Antioxidant Protection of Packaged Food by Incorporating Natural Flavonoids into Ethylene-Vinyl Alcohol Copolymer (EVOH) Films, Journal of Agricultural and Food Chemistry, 58 (2010) 10958-10964.

[107] C. Lopez-de-Dicastillo, R. Catala, R. Gavara, P. Hernandez-Munoz, Food applications of active packaging EVOH films containing cyclodextrins for the preferential scavenging of undesirable compounds, Journal of Food Engineering, 104 (2011) 380-386.

[108] A. Martinez-Abad, J.M. Lagaron, M.J. Ocio, Development and Characterization of SilverBased Antimicrobial Ethylene-Vinyl Alcohol Copolymer (EVOH) Films for Food-Packaging Applications, Journal of Agricultural and Food Chemistry, 60 (2012) 5350-5359.

[109] R. Rijk, R. Veraart, Global Legislation for Food Packaging Materials, Wiley, 2010. 



\section{OBJECTIVES}

As explained in the Introduction, the technology of antimicrobial active packaging is an alternative to direct addition of antimicrobial additives which can help to inhibit the proliferation of microorganisms in foods, thus extending the shelf life of the food product. Compared to direct addition of antimicrobial additives to food, antimicrobial active packaging technologies could stabilize labile additives or avoid interactions and chemical reactions, satisfying consumer demand for products with fewer additives.

The main objective of this Thesis was to develop antimicrobial active films based on ethylene vinyl alcohol copolymer $(E V O H)$ with antimicrobial compounds and to characterize their functional properties and, especially, their antimicrobial efficiency.

To achieve this main objective the following partial objectives were set:

1. Selection of the antimicrobial agents and study of their antimicrobial activity in vitro.

2. Development of ethylene vinyl alcohol copolymer films (EVOH29 and EVOH44) with antimicrobial agents by casting of a polymer solution containing the agents.

3. Development of ethylene vinyl alcohol copolymer (EVOH29 and EVOH44) films with the antimicrobial agent immobilized on the film surface.

4. Determination of the effect of the incorporation of antimicrobial agents into the polymer matrix on the functional properties of the films.

5. Studies of agent release from films into food simulants and characterization of the processes.

6. In vitro evaluation of the antimicrobial properties of the films against selected major foodborne pathogens.

7. Evaluation of the feasibility of using the antimicrobial films that have been developed as food packaging materials to enhance the preservation of food products susceptible to microbial contamination. 



\section{CHAPTERS}

The main objective of this Doctoral Thesis was the development and characterization of antimicrobial films based on ethylene vinyl alcohol copolymer (EVOH) with natural antimicrobial compounds. For this purpose, two different ways of producing antimicrobial materials were used: i) the addition of volatile and non-volatile antimicrobial agents to the film-forming polymer solution and film manufacture by a casting process; and ii) immobilization of the bioactive agent on the film surface by covalent bonding.

The work done to achieve this objective is presented in four separate chapters.

\section{Chapter I. Development of antimicrobial films with volatile compounds}

This chapter examines the antimicrobial activity of EVOH29 films with two natural volatile compounds, carvacrol from oregano essential oil and citral from lemon grass. In the first part, the films developed were used to pack minimally processed salads, combining modified atmosphere technology (MAP) and active packaging to extend product shelf life and to reduce possible microbiological risks. In the second part of the chapter the study was transferred from laboratory scale to semi-industrial scale.

\section{Chapter II. Development of antimicrobial films with non-volatile compounds}

The aim of this chapter was the development of antimicrobial films based on EVOH29 and EVOH44 containing non-volatile antimicrobial compounds intended for active packaging applications. Two EVOH copolymers (EVOH29 and EVOH44) were selected to determine the effect of matrix polarity on the antimicrobial behaviour of the active materials. The antimicrobial activity of the selected agents, ethyl lauroyl arginate and epsilon-polylysine, were studied before they were incorporated into the polymer matrix. Films were produced by casting and their properties were characterized. The antimicrobial activity of the films was studied in vitro against pathogenic bacteria and in vivo with various food matrices. The goal of this chapter was to demonstrate that these antimicrobial films were excellent candidates to extend food shelf life, providing a continuous antimicrobial effect against selected major pathogenic bacteria responsible for foodborne illnesses.

\section{Chapter III. Development of antimicrobial films combining volatile and non-volatile compounds}

The proposal of this chapter focuses on combining a volatile oregano essential oil (OEO) and a non-volatile antimicrobial compound, green tea extract, in two EVOH copolymers (EVOH29 and EVOH44). This type of packaging technology is an optional system that merges the beneficial effects of volatile and non-volatile agents and may reduce the 
amount of each antimicrobial that is required compared with the amount demanded when used alone. Experiments were performed to study the release kinetics from EVOH films to different food stimulants of the compounds with greater antimicrobial activity present in the essential oil and in the extract. The antimicrobial activity against pathogenic bacteria and moulds was also studied.

\section{Chapter IV. Development of antimicrobial films by immobilization of the bioactive agent on the polymer surface}

The objective of this chapter was to develop a new antimicrobial film in which lysozyme was covalently attached to the surface of EVOH29 and EVOH44 films. The antimicrobial activity of the films was tested against L. monocytogenes. It is proposed that these films should be applied as the inner surface of a package in which direct contact between the inner layer and a fluid food will produce improved food stability without the addition (or release) of additives. 


\section{CHAPTER I.}

\section{DEVELOPMENT OF}

ANTIMICROBIAL FILMS WITH VOLATILE COMPOUNDS

ARTICLE 1.

DEVELOPMENT OF ANTIMICROBIAL FILMS FOR MICROBIOLOGICAL CONTROL OF PACKAGED SALAD

\section{ARTICLE 2.}

EVALUATION OF EVOH-COATED PP FILMS WITH OREGANO ESSENTIAL OIL AND CITRAL TO IMPROVE THE SHELF-LIFE OF PACKAGED SALAD 

DEVELOPMENT OF

ANTIMICROBIAL FILMS FOR

MICROBIOLOGICAL CONTROL OF

PACKAGED SALAD

Virginia Muriel-Galet ${ }^{1}$, Josep P. Cerisuelo ${ }^{1}$,

Gracia López-Carballo ${ }^{1}$, Marta Lara²,

Rafael Gavaraz and Pilar Hernández-Muñoz ${ }^{1}$

International Journal of Food Microbiol, 2012 , 157, 195-201 


\section{ABSTRACT}

The aim of the present work was to characterize the antimicrobial efficiency of films consisting of PP/EVOH structures with oregano essential oil and citral. Both substances are known for their antimicrobial activity based on their interaction with the cell membrane. The films developed were used to pack minimally-processed salads, combining modified atmosphere technology to extend shelf-life and active packaging technology to reduce possible microbiological risks. The antimicrobial activity of the films against the pathogenic microorganisms E. coli, S. enterica and L. monocytogenes and natural microflora was investigated in vitro and also on the food itself. The effect of release of the antimicrobial agent on the sensory characteristics of the salad was also studied. The results showed that antimicrobial activity reduced spoilage flora on the salad as well as inhibiting the growth of pathogens in contaminated salads. This effect was greater against Gram-negative bacteria. Sensory studies showed that the package that was most effective and most accepted by customers was the one containing $5 \%$ oregano essential oil.

Keywords: antimicrobial packaging, oregano, citral, EVOH, antimicrobial release, pathogens, fresh salad 


\section{INTRODUCTION}

New trends in nutrition and modern lifestyle are producing an increasing demand for "ready-to-eat" products. Minimally processed salads are among the most requested products because they provide high nutritional value while maintaining their freshness appeal. Vegetables are considered essential in a balanced diet and part of the Mediterranean diet [1]. Minimally processed salads are manufactured by using several basic processes, including washing, sorting, cutting and peeling or slicing [2]. These operations may lead to cross-contamination, whereby even a small affected part of a vegetable can be responsible for contamination of the whole food sample. As a consequence, this microbiological contamination can alter fresh produce quality and safety and cause important foodborne illnesses.

Since there is no strategy for achieving complete elimination of hazardous microorganisms on fresh produce without affecting product quality [3], and there has been a great increase in the sale of fresh produce, the number of documented outbreaks of human infections related to the consumption of minimally processed vegetables has increased considerably in recent decades [4]. In general, decontamination of fresh vegetables is based on the application of chlorine, although there is industrial demand for natural alternative disinfectants [5]. Currently, there is increasing consumer pressure to replace chemically synthesized antimicrobials with natural alternatives in order to ensure food safety [6].

In this context, plant essential oils are attracting interest because of their potential as natural food preservatives, having a wide spectrum of antimicrobial activity, with potential for control of foodborne pathogens and spoilage bacteria associated with "ready-to-eat" vegetables [5, 7]. Essential oils of spices and plants significantly decrease the pathogenic bacteria counts of foods [8], with small terpenoids and phenolic compounds appearing to be responsible for their antimicrobial activity [9]. In this work, oregano essential oil and citral were selected as natural antimicrobial agents. $80 \%$ of oregano essential oil is carvacrol [10], a volatile phenolic compound characterized by strong antibacterial properties $[7,8,11,12]$. Citral is a volatile monoterpenoid containing an aldehyde group with a strong lemon flavour and is the main constituent of the lemon grass plant $[2,13]$. The antimicrobial activity of citron oil and citral has been tested on fruit-based salads, among other kinds of food [14].

Oregano essential oil and citral are classified as GRAS (Generally Recognised as Safe) by the Food Drug Administration (FDA) and as food additives by the European Union. However their use in food preservation remains limited, mainly because of their intense aroma, which could cause deterioration in the organoleptic properties of food. To minimize the dose required, an alternative would be the use of polymeric matrices as vehicles for these natural compounds. The major advantage of this technology is that because of the slow diffusion of the antimicrobial agent in the package wall the compound is released in a controlled way on the product surface (where the contamination is highest). This method is more effective than applying the antimicrobial agent directly on the surface of the product via a spray solution and can reduce the organoleptic impact [15].

An issue associated with minimally processed vegetables is their limited shelf 
life, which is usually no more than 8 days when stored in adequate conditions [13]. Currently, novel mild preservation techniques, particularly Modified Atmosphere Packaging (MAP), are increasingly being used for fresh-cut salad to ensure safety and quality, extending the period of commercialization. The positive effect of MAP on shelf life is the reduction in their rate of respiration and their metabolic and biochemical activities [16]. Active antimicrobial packaging is a possible improvement of MAP to enhance the quality, safety and shelf life of this kind of product, in which antimicrobial agents are added directly to the packaging material [17]. The volatile antimicrobial agents are incorporated into the polymer mass and released into the headspace surrounding the food.

In this work, ethylene-vinyl alcohol copolymer (EVOH) was used as a matrix to incorporate the natural antimicrobial agents. $\mathrm{EVOH}$ is a common packaging material that has excellent oxygen barrier proper- ties and a highly hydrophilic nature [17]. Furthermore, EVOH materials have been used recently as matrices for the development of active packaging systems, where the polymer protects the active agents during storage and triggers their activity on exposure to a humid environment (the food product) [18-20]. Since polypropylene (PP) bags are known to provide excellent functional properties for the packaging of minimally processed fresh produce in MAP [21], active EVOH was applied as a coating on PP film.

The aim of the present work was to develop a new antimicrobial active packaging consisting of PP/EVOH bags incorporating oregano essential oil or citral to be applied in the packaging of salad, and to characterize the antimicrobial effect of the package against E. coli, S. enterica and L. monocytogenes and food spoilage flora and the influence of the essential oils on the sensory attributes of the product.

\section{MATERIALS AND METHODS}

\subsection{Chemicals and reagents}

Ethylene vinyl alcohol copolymer with a 29\% ethylene molar content (EVOH) was kindly provided by The Nippon Synthetic Chemical Company (Osaka, Japan). 1-propanol, dimethyl sulfoxide (DMSO), oregano essential oil (CAS No: 8007-11-2) and citral (CAS No: 5392-40-5) were purchased from Sigma (Madrid, Spain). Polypropylene films and bags and salads were provided by Verdifresh (Ribarroja, Valencia, Spain). Salads: lettuce, carrot and red cabbage, were purchased from Verdifresh (Ribarroja, Valencia, Spain). Water was obtained from a Milli-Q Plus purification system (Millipore, Molsheim, France).

\subsection{Film preparation}

The polymer was dissolved in a 1:1 ( $\mathrm{v} / \mathrm{v})$ 1-propanol/water mixture at $50{ }^{\circ} \mathrm{C}$. The solution was stirred for 30 min using a magnetic stirrer hotplate. Then a concentration of $5 \%$ or $10 \%$ oregano essential oil or citral was added and the mixture was stirred again for about $15 \mathrm{~min}$. The $30 \mu \mathrm{m}$ thick PP films $(28 \mathrm{x} 40 \mathrm{~cm})$ were attached to a glass plate and radiated for 60 minutes under an UV lamp Xe-Excimer with 6 W at 172 nm (UV-Consulting Peschl España, Valencia, Spain) to improve the adhesion of the coating. $5 \mathrm{~mL}$ of the EVOH solution was spread over it using a bar coater; it was placed in a drying tunnel equipped with 
a $2500 \mathrm{~W}$ heat source for 10 min until it was completely dry. Finally, the films were stored in glass desiccators at $22{ }^{\circ} \mathrm{C}$ and $0 \%$ $\mathrm{RH}$ prior to use. Control films were obtained without essential oils. EVOH-coated PP films were used to make $15 \times 25 \mathrm{~cm}$ bags. Thickness of the coating was determined with a digital micrometer (Mitutoyo, Osaka, Japan).

\subsection{Identification and quantification of vo- latile compounds}

The carvacrol and citral compounds were analysed using a Dynatherm Thermal Desorber (Teknokroma S.A., Barcelona) connected in series to the column of an HP5890 Series II Plus (Agilent Technologies, Wilmington, DE, USA) gas chromatograph (GC) via heated transfer line. $1 \mathrm{~cm}^{2}$ of the film was inserted into an empty desorption tube. The tube was placed in the desorption chamber, which was immediately sealed. Conditions for desorption were as follows: desorption temperature $220^{\circ} \mathrm{C}$, transfer line $230^{\circ} \mathrm{C}$, desorption time $7 \mathrm{~min}$. The GC was equipped with an Ultra $(30 \mathrm{~m}$, $0.32 \mathrm{~mm}, 0.25 \mu \mathrm{m})$ column and flame ionization detector. After the analysis, the film sample was recovered from the desorption tube and weighed on an analytical balance. The thermal desorption - gas chromatography system was previously calibrated by measuring different amounts of carvacrol or citral [22].

\subsection{Antimicrobial tests}

\subsubsection{Strains}

The following foodborne microbial strains were obtained from the Spanish Type Culture Collection (Valencia, Spain) and selected for use in the assays because of their importance in the food industry: the Gramnegative bacteria Escherichia coli CECT 434 (ATCC 25922) and Salmonella enterica CECT 4300 (ATCC 13076); and the Grampositive bacterium Listeria monocytogenes
CECT 4032 (ATCC 33090). The strains were stored in Tryptone Soy Broth purchased from Scharlab (Barcelona, Spain) with $20 \%$ glycerol at $-80{ }^{\circ} \mathrm{C}$ until needed. For experimental use, the stock cultures were maintained by regular subculture on agar Tryptone Soy Agar from Scharlab (Barcelona, Spain) slants at $4{ }^{\circ} \mathrm{C}$ and transferred monthly. Prior to the experiment, a loopful of each strain was transferred to $10 \mathrm{~mL}$ of TSB and incubated at $37^{\circ} \mathrm{C}$ for $18 \mathrm{~h}$ to obtain early-stationary phase cells.

\subsubsection{Carvacrol and citral vapour inhibition assay}

$100 \mu \mathrm{L}$ of a bacteria suspension containing approximately $10^{7} \mathrm{CFU} / \mathrm{mL}$ was spread over the TSA surface. Each pure essential oil was diluted in DMSO to obtain serial concentrations. Dilutions were added to 25 mm sterile blank filter discs and adhered to the lid of a Petri dish. Plates were sealed with parafilm to reduce leakage of the volatile agent. Plates were incubated at $37^{\circ} \mathrm{C}$ for $24 \mathrm{~h}$ and the diameter of the resulting inhibition zone in the bacterial lawn was measured. Blanks prepared by adding 100 $\mu \mathrm{L}$ of DMSO to the filter discs showed that the DMSO did not have any effect against any of the microorganisms tested.

Similarly, discs of the antimicrobial films (25 $\mathrm{mm}$ in diameter) were adhered to the lid of a Petri dish, without direct contact with the microorganism. The Petri dishes and film assembly were sealed with parafilm and incubated under the conditions previously described. After the incubation period, the diameter of the resulting inhibition zone was measured. Controls without films and blanks with PP/EVOH films (without active compounds) were also tested. The experiment was carried out in triplicate.

The antimicrobial capacity of the PP/ EVOH bags, with oregano essential oil or citral, against E. coli, S. enteric and L. mono- 
cytogenes was studied. The inoculated Petri dishes were put into bags and sealed. The bags were stored for 8 days under refrigeration conditions, the first 5 days at $4{ }^{\circ} \mathrm{C}$ and the last 3 days at abusive temperature $\left(8^{\circ} \mathrm{C}\right)$. Finally, the bags were opened under sterile conditions, lidded and incubated at optimal temperature $\left(37^{\circ} \mathrm{C}\right.$ for $\left.24 \mathrm{~h}\right)$.

\subsubsection{Antimicrobial activity of films in mi- croflora of minimally processed salad}

The antimicrobial activity of the films was tested in vivo, by packaging $250 \mathrm{~g}$ of salad in bags manufactured with the PP/EVOH films developed. The packaging was done at Verdifresh (Ribarroja, Valencia, Spain) with a MULTIVAC A-NG 85021 packaging unit, and with an atmospheric composition of $12 \% \mathrm{CO}_{2}$ and $4 \% \mathrm{O}_{2}$.

Analyses were performed on the $1^{\text {st }}$ and $8^{\text {th }}$ days after packaging to check for the effect at the beginning of the storage when the agent concentrations should be maxima and the long-range effect when low concentration of antimicrobial should remain [22]. Samples were maintained at 4 ${ }^{\circ} \mathrm{C}$ for the first 5 days and at $8^{\circ} \mathrm{C}$ for the last 3 days. 25-g samples were weighed in sterile Stomacher bags, diluted with $10 \mathrm{~mL}$ of peptone water (Scharlab, Barcelona, Spain) and homogenized in Stomacher for 3 min (IUL S.L., Barcelona). Ten-fold dilution series were made in the same saline solution for plating. The enumeration of particular microbial groups was performed by using the following media (Scharlab, Barcelona, Spain) and culture conditions: a) Nutrient Agar for total aerobic plate count, pourplated and incubated at $30{ }^{\circ} \mathrm{C}$ for $48 \mathrm{~h}$, and also for total aerobic psychotropic count, pour-plated and incubated at $10{ }^{\circ} \mathrm{C}$ for 10 days; b) MEA for yeasts and moulds, pourplated and incubated at $25^{\circ} \mathrm{C}$ for 5 days; c) VRBD agar for total enterobacteria, pourplated, overlaid with the same medium and incubated aerobically at $37^{\circ} \mathrm{C}$ for $48 \mathrm{~h}$. The counts were performed in triplicate.

\subsubsection{Antimicrobial activity of films against pathogenic microorganisms in minimally processed salads}

Tests conditions for pathogenic bacteria were selected following the works of Lang et al. (2004) with some modifications [23]. In brief, bags were prepared with $25 \mathrm{~g}$ of freshly prepared salad, inoculating a concentration of $10^{7} \mathrm{CFU} / \mathrm{mL}$ of pure pathogenic microorganism. The bags were sealed and stored for 2 days at $4{ }^{\circ} \mathrm{C}$. Then the samples (25 g) were placed in sterile Stomacher bags, diluted with $25 \mathrm{~mL}$ of peptone water (Scharlab, Barcelona, Spain) and homogenized in Stomacher for 3 min. Serial dilutions were carried out and plated on selective media: brilliant green agar and palcam listeria selective agar (Scharlab, Barcelona, Spain). Colonies were counted after incubation at $37{ }^{\circ} \mathrm{C}$ for $48 \mathrm{~h}$. Samples were analysed in triplicate.

\subsection{Sensory analyses}

All sensory tests were carried out on the $1^{\text {st }}$ and $8^{\text {th }}$ days after packaging.

Visual appearance, odour and general acceptability were evaluated by an untrained panel (44 judges). The tests were done in a standardized test room (ISO 8589-2007). Samples of salad were placed in transparent glasses, covered with parafilm and identified by three-digit codes.

The sensory test consisted of two parts. First, a 9-point hedonic scale was used (1=dislike extremely, $5=$ neither like nor dislike, 9=like extremely) to determine the sensory properties: visual appearance, odour and general acceptability of four different samples: salad packaged with 10\% and 5\% of oregano essential oil and salad packaged with $10 \%$ and $5 \%$ of citral. The Williams method for constructing such designs was applied to the sensory studies [24].

Second, the sample with the highest scores 
and a control sample were evaluated by paired comparison test (ISO 5495-2005).

\subsection{Statistical analysis}

Statistical analysis of the microbiological and sensory data was performed by oneway ANOVA study. P-values of 0.05 or less were considered significant. The design of the sensory evaluation and the data analysis were carried out with Compusense Five software (release 5.5, Ontario, Canada).

\section{RESULTS AND DISCUSSION}

EVOH coatings containing 5 and 10\% oregano essential oil (5\% OEO and 10\% OEO) or citral (5\% citral and 10\% citral) were prepared on PP films as described in the experimental section. PP/EVOH film without antimicrobial agent was also obtained as control (control). The coatings of EVOH were transparent and without discontinuities, with an average thickness of $3.0 \pm$ $0.5 \mu \mathrm{m}$, value obtained by susbtracting the thickness of the uncoated film from that of the coated one. EVOH is known for its high barrier characteristics in dry which are severely reduced by the presence of humidity. Since the package developed here is for a fresh produce, a large reduction of permeability could imply the development of fermentative processes. The permeance of the materials were measured in dry and wet conditions (90\% RH). The permeance of the uncoated PP film (control) was 1300 $\mathrm{cc} / \mathrm{m}^{2}$.day.atm in both conditions. The coated materials presented a permeance of 5 $\mathrm{cc} / \mathrm{m}^{2}$.day.atm in dry conditions and 1000 $\mathrm{cc} / \mathrm{m}^{2}$.day.atm at 90\% RH which should be higher when in contact with the salad (98\% $\mathrm{RH})$. Therefore, no relevant permeance effect should be expected by the addition of the EVOH coating.

Since carvacrol is the major component of oregano essential oil and is mainly responsible for its antibacterial properties [8, 10], carvacrol was the only component of the OEO monitored in this study. The carvacrol and citral amounts retained in the coa- tings were measured by Thermal Desorption-Gas Chromatography. Films with 5\% oregano essential oil had a final carvacrol concentration of $2.8 \pm 0.2 \%$ and the films with 10\% OEO had $6.7 \pm 0.4 \%$. These results show a loss of carvacrol of about $20 \%$, which can be attributed to evaporation during the drying process. The films with citral had higher losses owing to its higher volatility. The final concentrations were 1.8 $\pm 0.2 \%$ and $5 \pm 0.2 \%$ for the samples with nominal 5 and 10\% citral, respectively.

The film samples obtained were stored in desiccators with silica gel. In these dry storage conditions, the concentration of the agents was maintained constant for 3 months. EVOH is characterized by its excellent gas and organic vapour barrier properties when dry, and therefore the release of carvacrol or citral is highly impeded in these storage conditions [17, 25].

\subsection{Antimicrobial activity of the agents in the vapour phase}

The antimicrobial effects of carvacrol and citral in the vapour phase against E. coli, S. enterica and L. monocytogenes were determined by the disc diffusion method as described in the experimental section. The inhibitory effect of carvacrol and citral is presented in Table 1. Although a clearly defined inhibition halo was not seen with the addition of $2.5 \mathrm{mg}$ of OEO or citral, it was possible to observe a reduction in 
growth for each of the three strains, a visible decrease in microbial density on the Petri dish which we have called a retraction zone. No inhibition was observed with the addition of lower amounts of the antimicrobial agents, and therefore $2.5 \mathrm{mg}$ was the minimum inhibitory concentration (MIC), defined as the lowest concentration of active compound that yields inhibition of microorganism [26, 27].

As shown in Table 1, 3 mg of citral produced a zone of inhibition against E. coli and L. monocytogenes, and a higher amount was necessary for S. enterica (5 mg). By increasing the amount of citral used in the assay, a higher zone of inhibition against the microorganism was obtained. Growth was totally inhibited with $7 \mathrm{mg}$ of citral.

Oregano essential oil produced a similar antimicrobial effect. However, a total inhibition zone was not observed even with a higher amount of oil (50 mg). An inhibition zone of $5.5 \mathrm{~cm}$ in diameter was formed with this large quantity. The reason for this effect is probably the DMSO; even though DMSO is an excellent solvent for essential oils, it may interfere with the release of carvacrol into the headspace. As can be seen in Table 1, the addition of 50 mg of oregano essential oil without DMSO produced a total inhibition zone. DMSO was used to standardize the volume added to the filter paper, but it also appeared as an unexpected factor that affected release of the agent.

\subsection{Antimicrobial activity of the agents incorporated in the PP/EVOH films by va- pour phase inhibition assay}

The antimicrobial activity of the PP/EVOH films was studied by the disc diffusion method. Table 2 shows the results obtained for the four films and the three microorganisms.

$\mathrm{PP} / \mathrm{EVOH}$ films with 5\% and 10\% citral produced a retraction zone for all three microorganisms tested, with no differences between the two concentrations tested. Considering the film sample used and the nominal citral concentration, the amounts of citral incorporated in the Petri dish were 90 and $180 \mu \mathrm{g}$ for the 5\% citral and 10\% citral films (32 and $90 \mu \mathrm{g}$ considering the amount of agent actually retained in the films). These values are much lower than those observed in the test with the paper disc.

The coatings incorporating 5\% and 10\% oregano essential oil produced a retraction zone for L. monocytogenes. However, clear inhibition zones of $7.25 \mathrm{~cm}$ for 5\% OEO and total inhibition for 10\% OEO against the two Gram-negative bacteria, E. coli and S. enterica, were observed, even though the amounts of OEO inserted in the Petri dishes were 90 and $180 \mu g$ (nominal values), much lower than the MIC measured with the paper discs.

These values were indicative that incorporation of the agent in the EVOH coating provides more antimicrobial activity than its incorporation in the paper disc. The reason for this effect is probably the difference in compatibility between substrate and antimicrobial agents. EVOH copolymer is a polar hydrophilic material, and it is well known that it plasticizes in the presence of high relative humidity, so that the polymer increases the polarity and reduces compatibility with nonpolar additives [18, 28]. Consequently, the antimicrobial agents reach the polymer surface and are quickly released into the atmosphere. In contrast, with the paper disc, the agents can get caught on the fibres of the paper disc and their release may be delayed. Also, the presence of DMSO might affect release from the paper, as mentioned above.

$\mathrm{PP} / \mathrm{EVOH}$ films with oregano essential oil were more effective against the Gramnegative ( $E$. coli and $S$. enterica) bacteria, 
Table 1. Effect of the amount of citral and oregano essential oil (OEO) on the growth inhibition of E. coli, S. enterica and L. monocytogenes determined using the disc diffusion method (agents added in DMSO solution, ${ }^{*}$ pure OEO) (Retraction zone: a visible decrease in microbial density on the Petri dish)

\section{Zone of inhibition $(\mathrm{cm})$}

\begin{tabular}{cccc} 
CITRAL $(\mathrm{mg})$ & E. coli & S. enterica & L. monocytogenes \\
\hline 2.5 & 2.25 & Retraction zone & 1.00 \\
\hline 3 & 2.25 & Retraction zone & 1.00 \\
\hline 4 & 2.25 & Retraction zone & 1.50 \\
\hline 5 & 4.75 & 3.75 & 4.50 \\
\hline 6 & 8.00 & 8.50 & 8.50 \\
\hline 7 & 8.50 & 8.50 & 8.50 \\
\hline OEO $(\mathrm{mg})$ & E. coli & S. enterica & L. monocytogenes \\
\hline 2.5 & Retraction zone & Retraction zone & Retraction zone \\
\hline 3 & 1.00 & 1.75 & Retraction zone \\
\hline 4 & 3.00 & 3.50 & 1.75 \\
\hline 5 & 3.25 & 3.50 & 3.00 \\
\hline 6 & 3.50 & 3.50 & 3.50 \\
\hline 15 & 3.25 & 3.25 & 4.00 \\
\hline 20 & 4.25 & 3.25 & 4.00 \\
\hline 25 & 4.25 & 4.50 & 4.50 \\
\hline 50 & 5.75 & 5.50 & 5.50 \\
\hline $50^{*}$ & 8.50 & 8.50 & 8.50 \\
\hline
\end{tabular}

producing an inhibition zone. This effect is probably caused by the affinity for the agents, especially for carvacrol, for the lipids of the outer membrane of Gram-negative bacteria, and the subsequent destabilization of the membrane, increase of the permeability of the cytoplasmic membrane and release of ions and cellular compounds [8]. Moreover, it has been reported that the cells of the microorganisms grown in the presence of non-lethal concentrations of carvacrol repress the synthesis of a phospholipid which is replaced by the synthesis of two additional phospholipids [8, 29].

Although most of the studies investigating the action of essential oils against food spoilage and foodborne pathogens have concluded that Gram-positive bacteria are more susceptible, several studies reflect si- milar or stronger inhibiting action against Gram-negative bacteria. Deans and Ritchie found no difference in the effectiveness of 50 commercial essential oils against the two types of bacteria [30]. Outtara et al. (1997) observed that several plant essential oils, including thyme and oregano, produced similar effects on Gram-negative and Grampositive bacteria after a $24 \mathrm{~h}$ treatment, while the inhibition effect appeared to be higher against Gram-negative bacteria after a $48 \mathrm{~h}$ treatment [31]. Also, variation in the composition of the essential oil samples [32] may be sufficient to cause variability in inhibition of Gram-negative and Grampositive bacteria.

In another study, Petri dishes inoculated with $10^{7} \mathrm{CFU} / \mathrm{mL}$ of E. coli, S. enterica, and L. monocytogenes were packaged in bags 
manufactured with PP/EVOH films. No antimicrobial effect was observed in samples packaged with the control bag (PP/ $\mathrm{EVOH}$ without agent), indicating that the gas barrier of the hermetic bag did not provide bactericidal or bacteriostatic effects. A total inhibition of bacterial growth of E. coli (Figure 1) and S. enterica by bags manufactured with the four active films (5\% citral, 10\% citral, 5\% OEO and 10\% OEO) was observed. Similar results were observed for L. monocytogenes in samples stored in bags with 5\% OEO, 10\% OEO and 10\% citral. However, with $5 \%$ citral a retraction was observed for L. monocytogenes. As noted above, a lower antimicrobial effect against L. monocytogenes may be observed because a higher concentration is required to achieve an inhibition effect.

The higher effectiveness of the agents in this study in comparison with the paper and film disc diffusion assays (Tables 1 and 2) is ascribable to the fact that the greater surface area $\left(750 \mathrm{~cm}^{2}\right)$ of the bags and the hermetic seal caused a higher compound concentration in the headspace than in the Petri dishes.

\subsection{Antimicrobial activity of active films on microflora of minimally processed salads}

Salad samples were packaged under modified atmosphere (MAP) using PP/EVOH films with oregano essential oil and citral at 5\% and 10\% nominal concentrations and stored at $4^{\circ} \mathrm{C}$ for 5 days and then at $8{ }^{\circ} \mathrm{C}$ for 3 days, simulating commercial conditions of production, transport and commercialization. This conditions were previously determined by López-Gálvez [3]. The samples were subjected to microbiological analysis on the $1^{\text {st }}$ day and the $8^{\text {th }}$ day of refrigerated storage. The results of microbiological counts of minimally processed salad samples are shown in Table 3.

On the $1^{\text {st }}$ day of storage, the total aerobic counts for salad packaged with the active samples showed a significant decrease in comparison with the control sample. OEO 10\% and citral 10\% samples had reductions of $1.89 \mathrm{log}$ and $1.91 \mathrm{log}$ respectively. With storage time, the aerobic population increased above 5 log in all cases, although a significant reduction in CFU was observed in all the active samples.

The enterobacteria count was reduced only in samples packaged with films containing $10 \%$ of active agent; for example, use of the OEO 10\% film reduced the enterobacteria count by 0.57 log after the first storage day. Similar results were observed after 8 days of storage. Citral 10\% and OEO 10\% samples produced a bacteria reduction of about 0.6 log. Although high levels of enterobacteria are common in raw vegetables, it is reported that they are not used to indicate the microbiological quality of fresh vegetables [33]. In any case, the films developed here reduced the counts of these spoilage organisms.

Table 3 also shows the antifungal effectiveness of the active films. After the $1^{\text {st }}$ day

Table 2. Antibacterial activity of PP/EVOH films with oregano essential oil (OEO) and citral against E. coli, S. enterica and L. monocytogenes.

\section{Coating}

\begin{tabular}{cccc}
\hline & E. coli & S. enterica & L. monocytogenes \\
\hline OEO 5\% & 7.25 & 7.25 & Retraction zone \\
\hline Citral 5\% & Retraction zone & Retraction zone & Retraction zone \\
\hline OEO 10\% & 8.50 & 8.50 & Retraction zone \\
\hline Citral 10\% & Retraction zone & Retraction zone & Retraction zone \\
\hline
\end{tabular}


of storage, a relevant significant antifungal effect was only shown by the films incorporating the higher antimicrobial concentrations. At the end of the storage period, all the active coatings produced significant inhibition, with a reduction of about 1 log. The OEO 5\% coating also provided antifungal activity, although the reduction was lower than for the other three treatments.

It is well known that psychotropic bacteria are able to grow at refrigerator temperature. The samples packaged with the OEO $10 \%$ and citral 10\% films showed an inhibition of approximately $0.5 \mathrm{log}$ at the beginning of storage at $4^{\circ} \mathrm{C}$. However, there was no measurable effect after 8 days of storage, probably because psychotropic bacteria counts increase at $8{ }^{\circ} \mathrm{C}$ and they reached a stationary state before the day of analysis.

From this study, it can be concluded that the active films developed provide inhibition of aerobic psychotropic bacteria in the first stages of the storage period, when the concentration of the agent in the package headspace is higher and the storage temperature lower. The counts of these bacteria increase by the end of the salad shelf life, and the protection of the film, although significant $(p<0.05)$, is less and probably of no practical value. In the case of enterobacteria, the reduction is only significant for the films containing the higher concentrations of the agents, and it produces a similar effect on day 1 and at the end of the storage period. As for yeast and moulds, the active principles appear to be very effective and practically inhibit their growth during the storage period [34-36].

\subsection{Antimicrobial activity of films against pathogenic microorganisms in minimally processed vegetables}

The salads were inoculated with the pathogenic microorganisms E. coli, S. enterica and L. monocytogenes, packaged in bags with the films developed and stored for two days

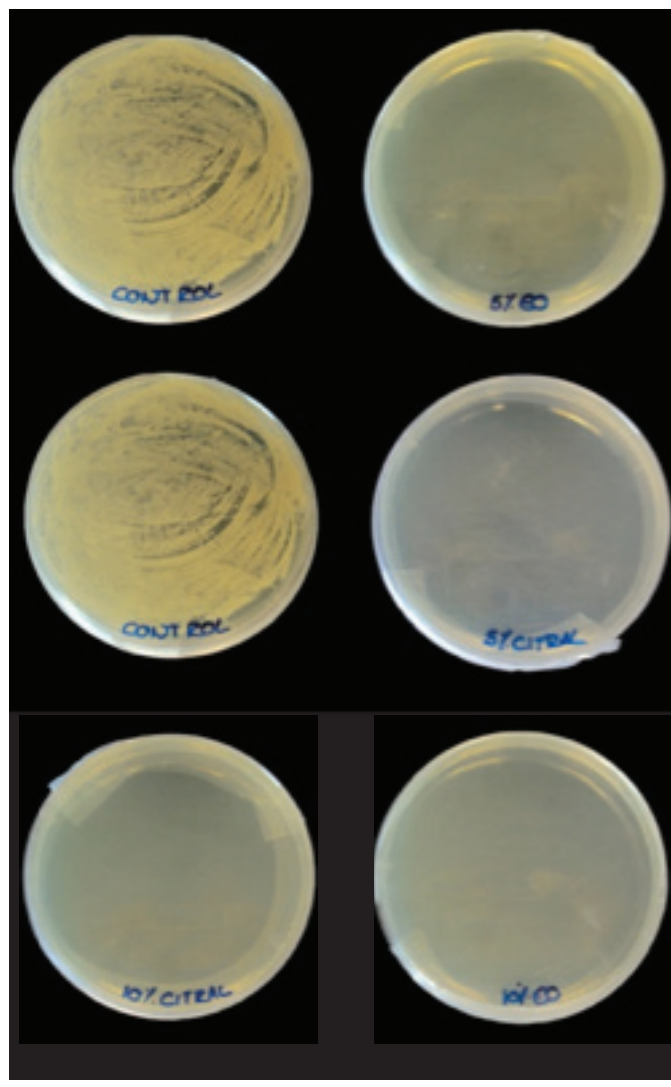

Figure 1. Antimicrobial effect against E. coli of bags coated with EVOH with 0, 5 and $10 \%$ oregano essential oil (A) and citral (B). Stored for 8 days, the first 5 days at $4^{\circ} \mathrm{C}$ and the last 3 days at $8{ }^{\circ} \mathrm{C}$.

at $4{ }^{\circ} \mathrm{C}$. These tests conditions were selected following the works of Lang et al. (2004) as described in the experimental section.

The inhibitory effect of PP/EVOH films with oregano essential oil and citral on of E. coli, S. enterica and L. monocytogenes is shown in Table 4. Samples stored in the active bags had a significant inhibitory effect against both Gram-negative bacteria tested. Samples contaminated with S. enterica and packaged with the active films presented a similar behaviour. Compared with the control sample, the presence of the volatile antimicrobial agents produced a reduction of between 0.3 and $0.5 \log$ CFU; the greater 
Table 3. Enumeration of microbial population in mixed salad packages: total aerobic, enterobacteria, yeast and psychotropic bacteria on $1^{\text {st }}$ and $8^{\text {th }}$ days of storage.

\section{TOTAL AEROBIC}

\begin{tabular}{rcccc}
\hline Coating & \multicolumn{2}{c}{ Day 1 } & Log & Reduction \\
\hline Adding & Log & \multicolumn{3}{c}{ Day 8 } \\
\hline Control & $5.35 \pm 0.04 \mathrm{c}$ & $6.09 \pm 0.03 \mathrm{c}$ \\
\hline OEO 5\% & $5.12 \pm 0.03 \mathrm{~b}$ & -0.23 & $5.78 \pm 0.01 \mathrm{~b}$ & -0.31 \\
\hline Citral 5\% & $5.09 \pm 0.07 \mathrm{~b}$ & -0.26 & $5.31 \pm 0.00 \mathrm{a}$ & -0.78 \\
\hline OEO 10\% & $3.46 \pm 0.10 \mathrm{a}$ & -1.89 & $5.84 \pm 0.17 \mathrm{~b}$ & -0.25 \\
\hline Citral 10\% & $3.44 \pm 0.11 \mathrm{a}$ & -1.91 & $5.78 \pm 0.03 \mathrm{~b}$ & -0.31 \\
\hline \multicolumn{7}{c}{ ENTEROBACTERIA } \\
\hline Control & $3.80 \pm 0.26 \mathrm{~b}$ & $-5.48 \pm 0.03 \mathrm{~b}$ & \\
\hline OEO 5\% & $4.09 \pm 0.07 \mathrm{~b}$ & - & $4.77 \pm 0.47 \mathrm{~b}$ & - \\
\hline Citral 5\% & $3.82 \pm 0.30 \mathrm{~b}$ & - & $4.38 \pm 0.13 \mathrm{ab}$ & -0.10 \\
\hline OEO 10\% & $3.23 \pm 0.04 \mathrm{a}$ & -0.57 & $3.90 \pm 0.14 \mathrm{a}$ & -0.58 \\
\hline Citral 10\% & $3.63 \pm 0.10 \mathrm{ab}$ & -0.17 & $3.85 \pm 0.12 \mathrm{a}$ & -0.64 \\
\hline
\end{tabular}

YEASTS AND MOULDS

\begin{tabular}{rlclc}
\hline Control & $4.94 \pm 0.08 \mathrm{~b}$ & \multicolumn{3}{c}{$5.95 \pm 0.07 \mathrm{~d}$} \\
\hline OEO 5\% & $5.04 \pm 0.08 \mathrm{~b}$ & - & $5.59 \pm 0.09 \mathrm{c}$ & -0.33 \\
\hline Citral 5\% & $4.90 \pm 0.05 \mathrm{~b}$ & -0.04 & $5.03 \pm 0.05 \mathrm{~b}$ & -0.92 \\
\hline OEO 10\% & $4.32 \pm 0.21 \mathrm{a}$ & -0.62 & $4.83 \pm 0.09 \mathrm{a}$ & -1.12 \\
\hline Citral 10\% & $4.68 \pm 0.03 \mathrm{ab}$ & -0.26 & $4.96 \pm 0.01 \mathrm{ab}$ & -1.00 \\
\hline
\end{tabular}

PSYCHOTROPIC

\begin{tabular}{rcccc}
\hline Control & $4.90 \pm 0.02 \mathrm{c}$ & & $5.98 \pm 0.01 \mathrm{~b}$ & \\
\hline OEO 5\% & $4.95 \pm 0.03 \mathrm{c}$ & - & $5.95 \pm 0.04 \mathrm{~b}$ & - \\
\hline Citral 5\% & $4.75 \pm 0.09 \mathrm{~b}$ & -0.15 & $4.78 \pm 0.10 \mathrm{a}$ & -1.20 \\
\hline OEO 10\% & $4.43 \pm 0.09 \mathrm{a}$ & -0.47 & $5.90 \pm 0.05 \mathrm{~b}$ & -0.08 \\
\hline Citral 10\% & $4.41 \pm 0.03 \mathrm{a}$ & -0.50 & $5.91 \pm 0.05 \mathrm{~b}$ & -0.07 \\
\hline
\end{tabular}

$a^{-c}$ Values within a column followed by a different lower-case letter are significantly different from each other (analysis of variance $P<0.05$ ).

the concentration of the agent, the higher the reduction.

In the case of the samples contaminated with $E$. coli, the bags containing the agents at $5 \%$ presented little or no effect. More effective activity was observed in the samples with a higher concentration of oils, both producing a significant reduction in bacterial counts. Interestingly, the OEO
$10 \%$ film was the most effective against this pathogen. Also, this sample was the only one that had a relevant effect on L. monocytogenes, in agreement with the lesser effectiveness of the selected agents against Gram-positive bacteria.

As commented earlier, the four active bags provided total inhibition against these three microorganisms placed on agar in $\mathrm{Pe}$ - 
tri dishes. In the study with real foodstuffs lower effects were observed, which can be attributed to partial sorption of the agent in the food, with a subsequent reduction of concentration in the vapour phase. A reduction of antimicrobial activity essential oils due to the nature of the food matrix has been documented [8, 14, 37]. Thus, higher concentrations of plant essential oils are generally required when added to food [7]. However, the application of essential oils in food may be limited owing to changes in the organoleptic and textural quality of the food or interactions of these compounds with food components [38].

\subsection{Sensory analyses}

The use of essential oils in ready-to-eat food may have a significant sensory impact that could result in non-acceptance by the consumer. For this reason, sensory analyses were carried out on the salads packaged with the films developed.

First, the effects of the addition of different agent concentrations and kinds of agents on the sensory properties of odour acceptability, visual appearance and general acceptability were studied. ANOVA analysis of data showed that the assessors perceived significant differences only in odour acceptability and general acceptability, depending on the agent concentration (5 or $10 \%$ ) as shown in Table 5. It can be seen in Table 6 that the increase in agent concentration leads to odour deterioration and therefore a decrease in acceptability of all samples. In terms of visual appearance, no significant differences were observed bet-

Table 4. Antimicrobial effects against E. coli, S. enterica and L. monocytogenes tested at $4{ }^{\circ} \mathrm{C}$ after 2 days of storage in contaminated packaged salad.

E. coli

\begin{tabular}{ccc}
\hline Coating & Log CFU & Log Reduction \\
\hline Control & $6.51 \pm 0.05 \mathrm{~d}$ & \\
\hline OEO 5\% & $6.58 \pm 0.04 \mathrm{~d}$ & - \\
\hline Citral 5\% & $6.38 \pm 0.06 \mathrm{c}$ & -0.12 \\
\hline OEO 10\% & $5.11 \pm 0.03 \mathrm{a}$ & -1.40 \\
\hline Citral 10\% & $6.15 \pm 0.03 \mathrm{~b}$ & -0.36 \\
\hline & S. enterica & \\
\hline Control & $6.85 \pm 0.01 \mathrm{c}$ & -0.32 \\
\hline OEO 5\% & $6.52 \pm 0.06 \mathrm{~b}$ & -0.34 \\
\hline Citral 5\% & $6.51 \pm 0.01 \mathrm{~b}$ & -0.50 \\
\hline OEO 10\% & $6.35 \pm 0.02 \mathrm{a}$ & -0.41 \\
\hline Citral 10\% & $6.43 \pm 0.02 \mathrm{ab}$ & \\
\hline
\end{tabular}

\section{L. monocytogenes}

\begin{tabular}{ccc}
\hline Control & $6.41 \pm 0.03 \mathrm{~b}$ & - \\
\hline OEO 5\% & $6.45 \pm 0.04 \mathrm{~b}$ & - \\
\hline Citral 5\% & $6.54 \pm 0.06 \mathrm{~b}$ & -0.36 \\
\hline OEO 10\% & $6.05 \pm 0.05 \mathrm{a}$ & - \\
\hline Citral 10\% & $6.56 \pm 0.04 \mathrm{~b}$ & \\
\hline
\end{tabular}

$a^{-c}$ Values within a column followed by a different lower-case letter are significantly different from each other (analysis of variance $P<0.05$ ). 
Table 5. Influence of the different antimicrobial agents and concentration on odour acceptability, visual appearance and general acceptability on the $1^{\text {st }}$ day and the $8^{\text {th }}$ day of storage. Results of the F and $\mathrm{p}$ values.

Day 1

\begin{tabular}{ccccccc} 
& \multicolumn{6}{c}{ Acceptability } \\
\cline { 2 - 7 } FACTORS & \multicolumn{2}{c}{ Odour } & Visual appearance & \multicolumn{2}{c}{ General } \\
\cline { 2 - 7 } & $F$ & $p$ & $F$ & $p$ & $F$ & $p$ \\
\hline A & 1.451 & 0.230 & 0.987 & 0.322 & 1.496 & 0.223 \\
\hline B & 6.890 & 0.009 & 0.337 & 0.562 & 7.095 & 0.008 \\
\hline AXB & 0.103 & 0.749 & 0.261 & 0.610 & 0.015 & 0.903 \\
\hline
\end{tabular}

A: antimicrobial agent, B: concentration, AXB: interaction.

Day 8

\begin{tabular}{cccccccc}
\cline { 2 - 7 } FACTORS & \multicolumn{9}{c}{ Acceptability } \\
\cline { 2 - 7 } & \multicolumn{2}{c}{ Odour } & \multicolumn{2}{c}{ Visual appearance } & \multicolumn{2}{c}{ General } \\
\hline & $F$ & $p$ & $F$ & $p$ & $F$ & $p$ \\
\hline A & 2.097 & 0.149 & 0.432 & 0.512 & 9.246 & 0.003 \\
\hline B & 9.886 & 0.002 & 48.993 & $<0.0001$ & 31.098 & $<0.0001$ \\
\hline AXB & 0.324 & 0.570 & 46.091 & $<0.0001$ & 5.501 & 0.020 \\
\hline
\end{tabular}

A: antimicrobial agent, B: concentration, AXB: interaction.

ween the samples. This can be explained by the fact that 1 storage day is not enough to cause deterioration of the sample.

On the $8^{\text {th }}$ day of storage, there were significant differences in general acceptability related with the kind of antimicrobial agent, with oregano essential oil being perceived as more acceptable than citral (Tables 5 and 6).

Significant differences were recorded for general acceptability, visual appearance and the interaction of both factors, which shows that the concentration effect depends on the antimicrobial agent. In general, as shown in Table 6, the visual appearance and general acceptability of the samples packaged with films containing oregano essential oil had better scores than the ones packaged with citral, and the samples with the lower agent concentrations were also preferred, so that OEO 5\% was the sample selected.
After the results of this first experiment, a paired comparison test was carried out to assess the differences in visual appearance and odour between minimally processed salad packaged with the OEO 5\% film and salad packaged with the control film. On day 1 of storage, no significant differences were found between the two samples. After 8 days of storage, the difference in acceptability of the odour of the two samples was not significant, but consumers preferred the visual appearance of salads with $5 \%$ essential oil of oregano. Likewise, on day 8 of storage the sample with oregano essential oil was clearly preferred.

Previous studies reported that the antimicrobial activity of plant essential oils decreased considerably when added to a complex food system [39, 40]. In the present study the in vitro assay with PP/EVOH films with oregano essential oil and citral produced excellent results against E. coli, S. enterica and L. monocytogenes, although 
Table 6. Values of the parameters of odour acceptability, visual appearance and general acceptability.

Acceptability

\begin{tabular}{ccccccc}
\cline { 2 - 6 } SAMPLE & \multicolumn{2}{c}{ Odour } & \multicolumn{2}{c}{ Visual appearance } & \multicolumn{2}{c}{ General } \\
\cline { 2 - 7 } & Day 1 & Day 8 & Day 1 & Day 8 & Day 1 & Day 8 \\
\hline OEO 5\% & $5.7^{\mathrm{a}}$ & $5.2^{\mathrm{a}}$ & $6.8^{\mathrm{a}}$ & $5.2^{\mathrm{b}}$ & $6.1^{\mathrm{a}}$ & $5.4^{\mathrm{a}}$ \\
\hline Citral 5\% & $5.4^{\mathrm{a}}$ & $4.7^{\mathrm{ab}}$ & $6.6^{\mathrm{a}}$ & $6.7^{\mathrm{a}}$ & $5.8^{\mathrm{a}}$ & $5.2^{\mathrm{ab}}$ \\
\hline OEO 10\% & $5.0^{\mathrm{ab}}$ & $4.2^{\mathrm{b}}$ & $6.7^{\mathrm{a}}$ & $5.2^{\mathrm{b}}$ & $5.4^{\mathrm{ab}}$ & $4.6^{\mathrm{b}}$ \\
\hline Citral 10\% & $4.5^{\mathrm{b}}$ & $4.0^{\mathrm{c}}$ & $6.4^{\mathrm{a}}$ & $3.4^{\mathrm{c}}$ & $5.0^{\mathrm{b}}$ & $3.2^{\mathrm{c}}$ \\
\hline
\end{tabular}

a-c Values within a column followed by a different lower-case letter are significantly different from each other (Tukey's-adjusted analysis of variance $P<0.05$ )

the antimicrobial effects observed on salad were lower due to agent/food matrix interactions. However, the films developed provided a significant inhibition of microflora commonly found on salad. Sensory evaluation suggested that PP/EVOH films with $5 \%$ oregano essential oil would be acceptable to consumers. Further studies are underway to improve controlled release of the agents and thus extend the antimicrobial effectiveness for a longer period.

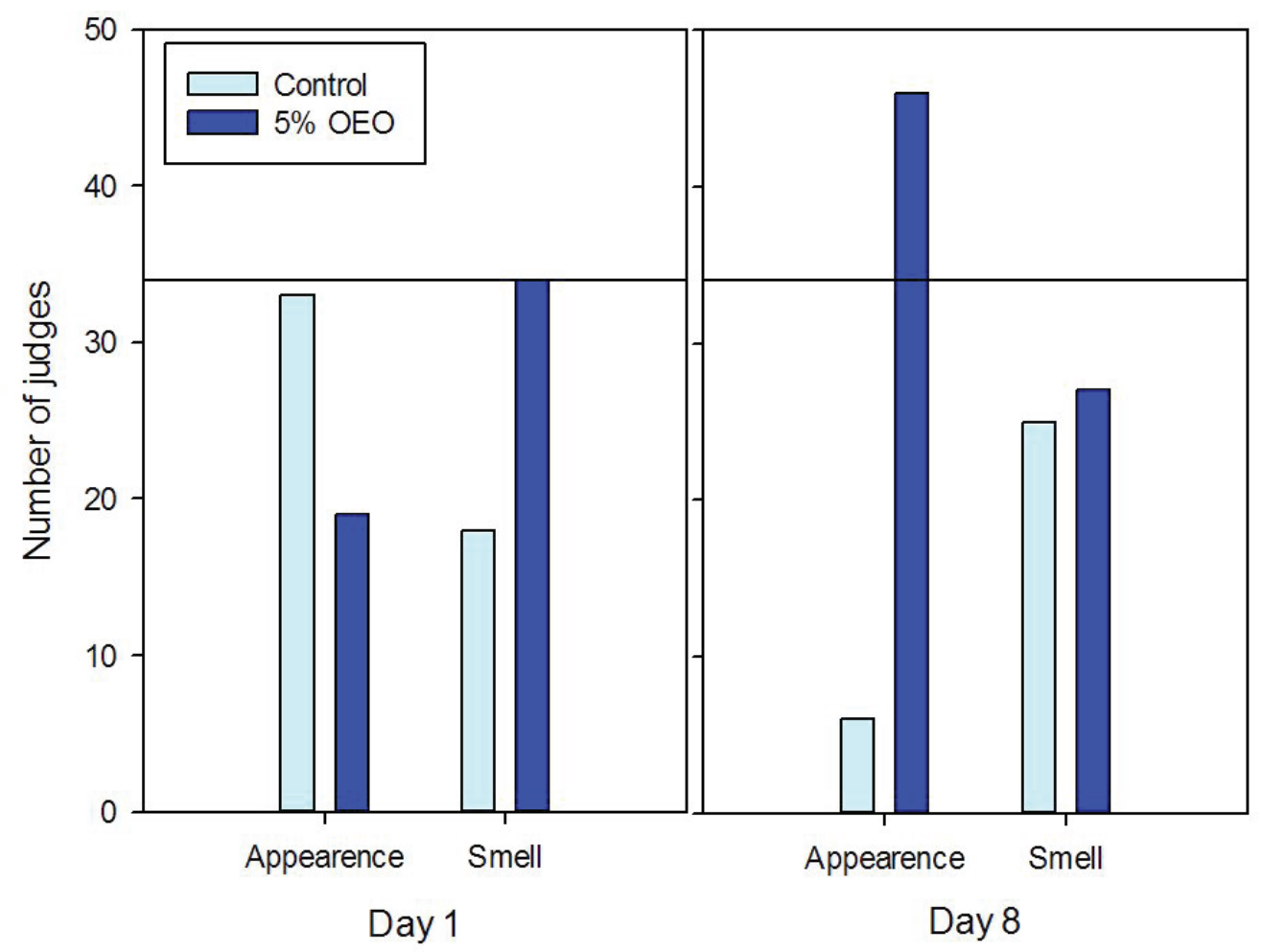

Figure 2. Sensory evaluation of the differences between the odour and appearance of 5\% oregano essential oil and the control. The line indicates the minimum value of responses for which the difference is significant. 


\section{REFERENCES}

[1] A. Trichopoulou, A. Naska, E. Vasilopoulou, Guidelines for the intake of vegetables and fruit: the Mediterranean approach, International Journal for Vitamin and Nutrition Research, 71 (2001) 149-153.

[2] N. Karagozlu, B. Ergonul, D. Ozcan, Determination of antimicrobial effect of mint and basil essential oils on survival of E. coli O157:H7 and S. typhimurium in fresh-cut lettuce and purslane, Food Control, 22 (2011) 1851-1855.

[3] F. Lopez-Galvez, M.I. Gil, P. Truchado, M.V. Selma, A. Allende, Cross-contamination of fresh-cut lettuce after a short-term exposure during pre-washing cannot be controlled after subsequent washing with chlorine dioxide or sodium hypochlorite, Food Microbiology, 27 (2010) 199-204.

[4] D. Gilliss, A. Cronquist, M. Cartter, M. Tobin-D'Angelo, D. Blythe, K. Smith, S. Lathrop, G. Birkhead, P. Cieslak, J. Dunn, K.G. Holt, J.J. Guzewich, O.L. Henao, B. Mahon, P. Griffin, R.V. Tauxe, S.M. Crim, Incidence and trends of infection with pathogens transmitted commonly through food - Foodborne Diseases Active Surveillance Network, 10 U.S. sites, 1996-2010, Morbidity and Mortality Weekly Report, 60 (2011) 749-755.

[5] J. Gutierrez, P. Bourke, J. Lonchamp, C. Barry-Ryan, Impact of plant essential oils on microbiological, organoleptic and quality markers of minimally processed vegetables, Innovative Food Science and Emerging Technologies, 10 (2009) 195-202.

[6] X. Wentao, Q. Wei, H. Kunlun, G. Feng, Y. Jiajia, Z. Heng, L. YunBo, Antibacterial effect of Grapefruit Seed Extract on food-borne pathogens and its application in the preservation of minimally processed vegetables, Postharvest Biology and Technology, 45 (2007) 126-133.

[7] J. Gutierrez, C. Barry-Ryan, P. Bourke, The antimicrobial efficacy of plant essential oil combinations and interactions with food ingredients, International Journal of Food Microbiology, 124 (2008) 91-97.
[8] S. Burt, Essential oils: their antibacterial properties and potential appliations in foods - a review, International Journal of Food Microbiology, 94 (2004) 223-253.

[9] I.M. Helander, H.L. Alakomi, K. Latva-Kala, T. Mattila-Sandholm, I. Pol, E.J. Smid, L.G.M. Gorris, A.v. Wright, Characterization of the action of selected essential oil components on Gram-negative bacteria, Journal of Agricultural and Food Chemistry, 46 (1998) 3590-3595.

[10] J. Varma, N.K. Dubey, Efficacy of essential oils of Caesulia axillaris and Mentha arvensis against some storage pests causing biodeterioration of food commodities, International Journal of Food Microbiology, 68 (2001) 207-210.

[11] H.J.D. Dorman, S.G. Deans, Antimicrobial agents from plants: antibacterial activity of plant volatile oils, Journal of Applied Microbiology, 88 (2000) 308-316.

[12] M. Oussalah, S. Caillet, M. Lacroix, Mechanism of action of Spanish oregano, Chinese cinnamon, and savory essential oils against cell membranes and walls of Escherichia coli 0157:H7 and Listeria monocytogenes, Journal of Food Protection, 69 (2006) 1046-1055.

[13] A. Allende, F. Artes, Combined ultraviolet-C and modified atmosphere packaging treatments for reducing microbial growth of fresh processed lettuce, Lebensmittel-Wissenschaft und -Technologie, 36 (2003) 779-786.

[14] N. Belletti, R. Lanciotti, F. Patrignani, F. Gardini, Antimicrobial efficacy of citron essential oil on spoilage and pathogenic microorganisms in fruit-based salads, Journal of Food Science, 73 (2008) M331-M338.

[15] S. Quintavalla, L. Vicini, Antimicrobial food packaging in meat industry, Meat Science, 62 (2002) 373-380.

[16] G.O. Scifo, C.L. Randazzo, C. Restuccia, G. Fava, C. Caggia, Listeria innocua growth in fresh cut mixed leafy salads packaged in modified atmosphere, Food Control, 20 (2009) 611-617. 
[17] S. Aucejo, R. Catala, R. Gavara, Interactions between water and EVOH food packaging films, Food Science and Technology International/ Ciencia y Tecnologia de Alimentos Internacional, 6 (2000) 159-164.

[18] C. Lopez-de-Dicastillo, J.M. Alonso, R. Catala, R. Gavara, P. Hernandez-Munoz, Improving the antioxidant protection of packaged food by incorporating natural flavonoids into ethylenevinyl alcohol copolymer (EVOH) films, Journal of Agricultural and Food Chemistry, 58 (2010) 10958-10964.

[19] C. Lopez-de-Dicastillo, R. Catala, R. Gavara, P. Hernandez-Munoz, Food applications of active packaging EVOH films containing cyclodextrins for the preferential scavenging of undesirable compounds, Journal of Food Engineering, 104 (2011) 380-386.

[20] C. Lopez-de-Dicastillo, M. Gallur, R. Catala, R. Gavara, P. Hernandez-Munoz, Immobilization of beta-cyclodextrin in ethylene-vinyl alcohol copolymer for active food packaging applications, Journal of Membrane Science, 353 (2010) 184-191.

[21] R. Catala, R. Gavara, Packaging requirements for nonthermally processed foods, Alimentacion Equipos y Tecnologia, (2009) 47-51.

[22] V. Muriel-Galet, J.P. Cerisuelo, G. LópezCarballo, M. Lara, R. Gavara and P. HernándezMuñoz, Development of antimicrobial films for microbiological control of packaged salad, International Journal of Food Microbiology, (2012).

[23] M.M. Lang, L.J. Harris, L.R. Beuchat, Survival and recovery of Escherichia coli O157:H7, Salmonella, and Listeria monocytogenes on lettuce and parsley as affected by method of inoculation, time between inoculation and analysis, and treatment with chlorinated water, Journal of Food Protection, 67 (2004) 1092-1103.

[24] H.J. MacFie, N. Bratchell, K. Greenhoff, L.V. Vallis, Designs to balance the effect of order of presentation and first-order carry-over effects in hall tests, Journal of Sensory Studies, 4 (1989) 129-148.
[25] G. Lopez-Carballo, D. Cava, J.M. Lagaron, R. Catala, R. Gavara, Characterization of the interaction between two food aroma components, alpha-pinene and ethyl butyrate, and ethylenevinyl alcohol copolymer (EVOH) packaging films as a function of environmental humidity, Journal of Agricultural Food Chemestry, 53 (2005) 7212-7216.

[26] K.A. Hammer, C.F. Carson, T.V. Riley, Antimicrobial activity of essential oils and other plant extracts, Journal of Applied Microbiology, 86 (1999) 985-990.

[27] P.J. Delaquis, K. Stanich, B. Girard, G. Mazza, Antimicrobial activity of individual and mixed fractions of dill, cilantro, coriander and eucalyptus essential oils, International Journal of Food Microbiology, 74 (2002) 101-109.

[28] G. Lopez-Carballo, D. Cava, J.M. Lagaron, R. Catala, R. Gavara, Characterization of the interaction between two food aroma components, alpha-pinene and ethyl butyrate, and ethylene-vinyl alcohol copolymer (EVOH) packaging films as a function of environmental humidity, Journal of Agricultural and Food Chemistry, 53 (2005) 7212-7216.

[29] A. Ultee, E.P.W. Kets, M. Alberda, F.A. Hoekstra, E.J. Smid, Adaptation of the food-borne pathogen Bacillus cereus to carvacrol, Archives of Microbiology, 174 (2000) 233-238.

[30] S.G. Deans, G. Ritchie, Antibacterial properties of plant essential oils, International Journal of Food Microbiology, 5 (1987) 165-180.

[31] B. Ouattara, R.E. Simard, R.A. Holley, G.J.P. Piette, A. Begin, Antibacterial activity of selected fatty acids and essential oils against six meat spoilage organisms, International Journal of Food Microbiology, 37 (1997) 155-162.

[32] J. Novak, J. Langbehn, F. Pank, C.M. Franz, Essential oil compounds in a historical sample of marjoram (Origanum majorana L., Lamiaceae), Flavour and Fragrance Journal, 17 (2002) 175-180. 
[33] C. Little, D. Roberts, E. Youngs, J.d. Louvois, Microbiological quality of retail imported unprepared whole lettuces: a PHLS Food Working Group study, Journal of Food Protection, 62 (1999) 325-328.

[34] A. Kunicka-Styczynska, Activity of essential oils against food-spoiling yeast. A review, Flavour and Fragrance Journal, 26 (2011) 326328.

[35] S.A. Valencia-Chamorro, L. Palou, M.A. del Rio, M.B. Perez-Gago, Antimicrobial Edible Films and Coatings for Fresh and Minimally Processed Fruits and Vegetables: A Review, Critical Reviews in Food Science and Nutrition, 51 (2011) 872-900.

[36] S. Ozcakmak, M. Dervisoglu, The inhibition of contaminated molds by some essential oils in cheeses, Gida, 36 (2011) 177-184.

[37] R. Lanciotti, A. Gianotti, F. Patrignani, N. Belletti, M.E. Guerzoni, F. Gardini, Use of natural aroma compounds to improve shelf-life and safety of minimally processed fruits, Trends in Food Science \& Technology, 15 (2004) 201-208.

[38] F. Devlieghere, K. Francois, K.M. Vereecken, A.H. Geeraerd, J.F.v. Impe, J. Debevere, Effect of chemicals on the microbial evolution in foods, Journal of Food Protection, 67 (2004) 1977-1990.

[39] F.F. Busta, M.L. Speck, Antimicrobial Effect of Cocoa on Salmonellae, Applied Microbiology, 16 (1968) 424-\&.

[40] R. Firouzi, S.S. Shekarforoush, A.H.K. Nazer, Z. Borumand, A.R. Jooyandeh, Effects of essential oils of oregano and nutmeg on growth and survival of Yersinia enterocolitica and Listeria monocytogenes in barbecued chicken, Journal of Food Protection, 70 (2007) 2626-2630. 


\section{EVALUATION OF EVOH-COATED \\ PP FILMS WITH OREGANO}

ESSENTIAL OIL AND CITRAL TO

IMPROVE THE SHELF-LIFE OF

PACKAGED SALAD

Virginia Muriel-Galet ${ }^{1}$, Josep P. Cerisuelo ${ }^{1}$,

Gracia López-Carballo ${ }^{1}$, Susana Aucejo²,

Rafael Gavara ${ }^{1}$ and Pilar Hernández-Muñoz ${ }^{1}$

Food Control 2013, 30, 137-143 


\section{ABSTRACT}

The aim of this study was to improve the present packaging of salad by combining modified atmosphere packaging with a new antimicrobial active bag consisting of PP/EVOH film with oregano essential oil or citral, with the purpose of extending shelf-life and reducing possible microbiological risks. The $\mathrm{O}_{2}$ and $\mathrm{CO}_{2}$ barrier properties of PP/EVOH, mechanical properties (Young's modulus, tensile strength and elongation at break) were determined and compared with those of standard PP films. Antimicrobial tests were carried out for enterobacteria, total aerobic counts, yeasts and moulds, and lactic acid bacteria and psychrotrophic bacteria, and the effect of the release of the antimicrobial agent on the sensory characteristics of the salads was also studied. The application of the EVOH coating results in an increase in the tensile resistance of the PP films and a reduction in the elongation at break. The results showed that microorganism counts bacteria decreased especially at the beginning of the storage period. OEO and CITRAL samples had reductions of $1.38 \mathrm{log}$ and $2.13 \log$ respectively against enterobacterias, about 2 log against yeasts and moulds. The total aerobic counts reduced $1.08 \mathrm{log}$ with OEO and 1.23 log with CITRAL and the reduction of lactic acid bacteria and psychrotrophic was about 2 log. Citral-based films appeared to be more effective than materials containing oregano essential oil in reducing spoilage flora during storage time. Sensory studies also showed that the package with citral was the most accepted by customers at the end of the shelf life.

Keywords: minimally processed salads, citral, oregano essential oil, antimicrobial packaging, mechanical properties, EVOH. 


\section{INTRODUCTION}

Consumer demand for healthy, fresh-like, easy-to-prepare products coupled with consumer lifestyles changes have led to the development of a variety of novel products, of which minimally processed salads are an example. Cut vegetables are more susceptible to chemical and microbiological deterioration because during the cutting, cells are destroyed and exudates rich in minerals, sugar, vitamins, and other compounds are released. These nutrients and storage conditions may allow growth of microorganisms [1]. During the last decades food borne outbreaks associated with consumption of raw vegetables have been increasing and green leafy vegetables seem to be the most frequently implicated products [2].

In order to extend the shelf life of minimally processed products, various technologies are available including well implemented equilibrium modified atmosphere packaging (MAP) $[3,4]$ and more recently antimicrobial active packaging. The combination of active antimicrobial packaging and MAP is a possible alternative to enhance the quality, safety and shelf-life of products of this kind, in which antimicrobial agents added directly to the packaging material are released exerting their activi- ty on the packaged product [5].

In a previous work [6], oregano essential oil and citral were incorporated in an ethylene-vinyl alcohol copolymer (EVOH) matrix and a preliminary study on the antimicrobial activity of the films and on the sensory attributes of salad was reported. Results showed that the antimicrobial activity increased with concentration of the antimicrobial agent in the film but also increased the sensory perception of off-flavors. EVOH materials have been used recently as matrices for the development of active packaging systems, where the polymer triggers their activity on exposure to a humid environment (the food product) [7-9].

In this work, active EVOH coated polypropylene (PP) films were manufactured using gravure printing technologies and used for modified atmosphere packaging of fresh produce in a processing plant. The aim of this study was to improve the stability of a mixed vegetable salad with the new antimicrobial active packaging that released oregano essential oil or citral combined with MAP and to characterize the films and the antimicrobial and sensory effects on salad.

\section{MATERIALS AND METHODS}

\subsection{Chemicals and reagents}

Ethylene vinyl alcohol copolymer with a 29\% ethylene molar content (EVOH) was kindly provided by The Nippon Synthetic Chemical Company (Osaka, Japan). Oregano essential oil and citral were purchased from Sigma (Madrid, Spain). Polypropylene films were provided by Envaflex (Utebo, Zaragoza, Spain). "Four season salad" (a mixture of cut iceberg lettuce, red cabbage and shredded carrot) was purchased from Verdifresh (Ribarroja, Valencia, Spain). Water was obtained from a Milli-Q Plus purifica- 
tion system (Millipore, Molsheim, France).

\subsection{Film preparation}

A coating technology based on gravure printing was used to produce the antimicrobial material at Envaflex at a production speed of $60 \mathrm{~m} / \mathrm{min}$. Based on the results of previous work [10], the antimicrobial films were produced by incorporating a known concentration $(7.5 \% \mathrm{w} / \mathrm{w})$ of oregano essential oil (OEO) or citral (CITRAL) in the EVOH coating solution. Polypropylene films were treated with corona and a primer based on polyethylene imine (Mica Corp., Kansas City, USA) was applied to improve adherence. EVOH coating was applied on the PP films, keeping an area uncoated to maintain sealability for the manufacture of the salad bags. Specifically, of the $1140 \mathrm{~cm}^{2}$ of film that was used to manufacture a bag, only $750 \mathrm{~cm}^{2}$ of surface was coated. Control films were obtained without active agents (CONTROL).

Thicknesses of the films were measured at 10 points of samples. The thickness of the coating was calculated from the difference in thickness between coated and uncoated areas.

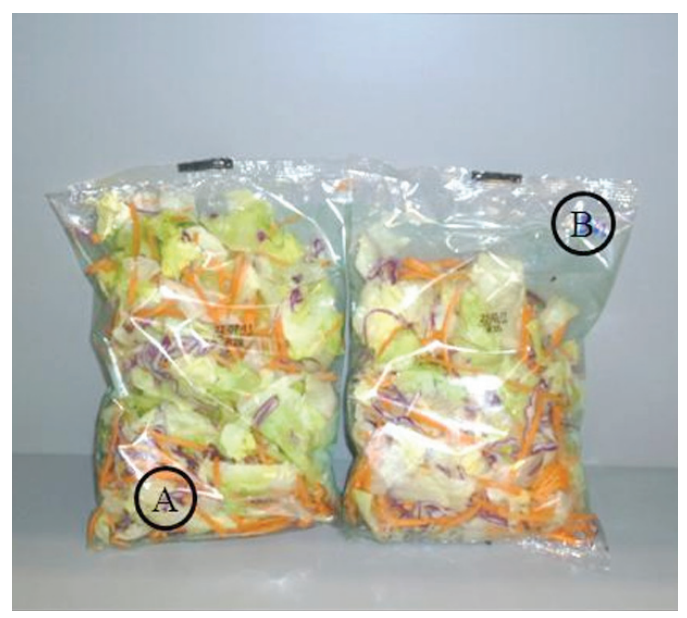

Figure 1. "Four season salad" bags in PP/EVOH films with oregano essential oil (A) and citral (B) in active modified atmosphere.

\subsection{Packaging and storage}

"Four season salad" was packed in individual bags manufactured with the various films with (OEO and CITRAL) and without agents (CONTROL) as shown in Figure 1. The packaging was done at Verdifresh (Ribarroja, Valencia, Spain) with a MULTIVAC A-NG 85021 packaging unit, and with an atmospheric composition of $12 \% \mathrm{CO}_{2}$ and $4 \% \mathrm{O}_{2}$. Bags of "four season salad" were stored for 5 days at $4{ }^{\circ} \mathrm{C}$ plus 3 days at $8{ }^{\circ} \mathrm{C}$, simulating commercial conditions of production, transport and commercialization [11].

\subsection{Identification and quantification of vo- latile compounds}

The equilibrium concentration of carvacrol (main component of oregano essential oil) and citral in the polymer samples was determined by thermal desorption and GC analysis using a thermal-desorber (890/891 model, Dynatherm Analytical Inst., Supelco, Bellafonte, PA, USA) connected in series to the gas chromatograph [12]. In brief, a portion of the tested film (ca. 1 $\mathrm{cm}^{2}$ ) was placed in the desorption cell and heated at $210^{\circ} \mathrm{C}$ for $7 \mathrm{~min}$. A He gas stream carried the desorbed compounds to the GC through a transfer line heated at $230{ }^{\circ} \mathrm{C}$. The GC was equipped with a $30 \mathrm{~m}, 0.53$ mm, $2.65 \mu \mathrm{m}$ Agilent HP-1 semicapillary column. The chromatographic conditions were: $\mathrm{He}$ as the carrier gas, $210^{\circ} \mathrm{C}$ and $260{ }^{\circ} \mathrm{C}$ injector and detector temperatures, $7 \mathrm{~min}$ at $45^{\circ} \mathrm{C}$, heating ramp to $220^{\circ} \mathrm{C}$ at $18{ }^{\circ} \mathrm{C} / \mathrm{min}$, and $12 \mathrm{~min}$ more at $220^{\circ} \mathrm{C}$. At the end of the desorption process the sample was weighed with a $0.1 \mathrm{mg}$ precision balance (Voyager V11140 model, Ohaus, Switzerland). Calibration was done by injecting known amounts of carvacrol or citral in the desorption cell.

\subsection{Oxygen and carbon dioxide permeance}

The measurements of $\mathrm{O}_{2}$ and $\mathrm{CO}_{2}$ permean- 
ce through the film samples were carried out using isostatic methods [9]. The $\mathrm{O}_{2}$ permeation rates of the materials were determined at $\mathrm{O}$ and $90 \% \mathrm{RH}$ and $23^{\circ} \mathrm{C}$ using an OXTRAN Model 2/21 ML Mocon (Lippke, Neuwied, Germany). The $\mathrm{CO}_{2}$ permeation rates of the materials were determined at 0 and $90 \% \mathrm{RH}$ and $23{ }^{\circ} \mathrm{C}$ using an assembly that makes use of a gas chromatograph as detector.

The evolution of headspace atmosphere composition during storage was carried out by withdrawal of $20 \mathrm{~mL}$ gas samples and injection on a Checkmaster gas analyzer (Lippke, Germany).

\subsection{Mechanical properties}

A Mecmesin model MultiTest 1-I universal machine (Landes Poli Ibércia, S.L., Barcelona, Spain) equipped with a $100 \mathrm{~N}$ static load cell was used to evaluate the maximum tensile strength $(\delta \mathrm{m})$, percentage of elongation at break $(\varepsilon \mathrm{b})$ and Young's modulus (E) of the films according to ASTM standard method D882 [13]. The films were conditioned at 50\% RH and room temperature for at least 1 week prior to testing. Film samples were cut into strips $2.54 \mathrm{~cm}$ wide and $10 \mathrm{~cm}$ long. The grip separation was set at $5.08 \mathrm{~cm}$ and the cross-head speed at 25 $\mathrm{mm} \cdot \mathrm{min}^{-1}$. At least 6 replicates from each sample were tested. The tensile properties were calculated from the plot of stress (tensile force/initial cross-section area) versus strain (elongation as a fraction of the original length).

\subsection{Antimicrobial activity of films on mi- croflora of minimally processed salad}

The antimicrobial activity of the films was tested in vivo. Analyses were performed on the $1^{\text {st }}, 4^{\text {th }}$ and $8^{\text {th }}$ days after packaging. 25-g samples of the packaged salad were weighed in sterile Stomacher bags, diluted with $25 \mathrm{~mL}$ of peptone water (Schar- lab, Barcelona, Spain) and homogenized in Stomacher for 3 min (IUL S.L., Barcelona). Ten-fold dilution series were made in the same saline solution for plating.

The enumeration of particular microbial groups was performed by using the following media (Scharlab, Barcelona, Spain) and culture conditions: a) Nutrient Agar for total aerobic plate count, pour-plated and incubated at $30{ }^{\circ} \mathrm{C}$ for $48 \mathrm{~h}$, and also for total aerobic psychrotropic count, pourplated and incubated at $10^{\circ} \mathrm{C}$ for 10 days; b) MEA for yeasts and moulds, pour-plated and incubated at $25^{\circ} \mathrm{C}$ for 5 days; c) VRBD agar for total enterobacteria, pour-plated, overlaid with the same medium and incubated aerobically at $37^{\circ} \mathrm{C}$ for $48 \mathrm{~h}$; d) MRS agar for lactic acid bacteria, pour-plated and incubated at $25^{\circ} \mathrm{C}$ for 5 days. The counts were performed in triplicate.

\subsection{Sensory analyses}

A group of 51 panellists, consumers of ready-to-eat fresh products with no previous experience, evaluated the smell, visual appearance, texture and general acceptability of the samples by paired comparison tests (ISO 5495-2005). A total of three pairs of samples were evaluated. Each pair consisted of two samples. The first pair were samples packaged with CONTROL and OEO films, the second pair were CONTROL and CITRAL, and the third pair were OEO and CITRAL.

Three pairs of samples were evaluated in each session and a total of two sessions was performed: on the $1^{\text {st }}$ day, to determine the initial impact of the aromatic agent, and on the $8^{\text {th }}$ day after packaging, to verify the quality and acceptability at the end of storage. The tests were done in a standardized test room (ISO 8589-2007). Samples of "Four season salad" were placed in $\mathrm{PP} / \mathrm{EVOH}$ bags identified by three-digit codes. The Williams method for constructing such designs was applied to the sensory studies [14]. 


\subsection{Statistical analysis}

Statistical analysis of the data was performed by one-way ANOVA study. The SPSS ${ }^{\circledR}$ computer program (SPSS Inc., Chicago, IL, USA) was used. Differences in pairs of mean values were evaluated by the Tukey- b test for a confidence interval of 95\%. Data are represented as mean \pm standard deviation. The design of the sensory evaluation and the data analysis were carried out with Compusense Five software (release 5.5, Ontario, Canada).

\section{RESULTS AND DISCUSSION}

PP/EVOH films containing oregano essential oil (OEO) or citral (CITRAL) were prepared as described in the experimental section. PP/EVOH film without antimicrobial agent was also obtained as control (CONTROL). The EVOH coatings had a thickness of $1.15 \pm 0.05 \mu \mathrm{m}$.

One of the major components of oregano essential oil is carvacrol (72.46\%), which is responsible for its antimicrobial properties $[15,16]$. Because of this, carvacrol was the only component of the OEO monitored in this study. Films with $7.5 \%$ oregano essential oil had a final carvacrol concentration of $3.5 \pm 0.2 \%$. These results show a carvacrol loss of about $35 \%$, which can be attributed to evaporation during the drying process. The films with citral had higher losses owing to its higher volatility. The final concentration was $2.6 \pm 0.2 \%$.

The film samples obtained were stored in desiccators with silica gel. In these dry storage conditions, the concentration of the agents was maintained constant for 3 months. EVOH is characterized by its excellent gas and organic vapour barrier pro- perties when dry, and therefore the release of carvacrol or citral is highly impeded in these storage conditions $[9,17]$.

\subsection{Oxygen and carbon dioxide permeance}

Permeance ( $\mathrm{D})$ to $\left(\mathrm{O}_{2}\right)$ and $\left(\mathrm{CO}_{2}\right)$ was evaluated under two relative humidity conditions: 0\% and 90\%. Table 1 shows the values for all the samples. As can be seen, the incorporation of the coating results in an increase in barrier which is very considerable in dry conditions. The permeance to both $\mathrm{O}_{2}$ and $\mathrm{CO}_{2}$ is reduced by more than 100fold. This effect is to be expected, owing to the well-known high barrier properties of EVOH. Nevertheless, the effect is severely reduced by humidity because of water plasticization of EVOH. The permeance decrease caused by the coating process on the PP film was 1.5-fold for $\mathrm{O}_{2}$ and 4-fold for $\mathrm{CO}_{2}$ in the coated area. Permeance values for the materials with the agents could not be measured because of the sensitivity of the Oxtran sensor to volatile organic compounds and their interference with the chromatographic detector used in the

Table 1. Values of $\mathrm{O}_{2}$ and $\mathrm{CO}_{2}$ permeance of PP films and PP/EVOH.

\begin{tabular}{rccccc} 
& $\begin{array}{c}\text { Thickness } \\
(\mu \mathrm{m})\end{array}$ & \multicolumn{2}{c}{$\begin{array}{c}10^{14} \cdot \mathbf{O}_{2} \text { permeance } \\
\left(\mathrm{m}^{3} / \mathrm{m}^{2} \cdot \mathrm{s} \cdot \mathrm{Pa}\right)\end{array}$} & \multicolumn{2}{c}{$\begin{array}{c}10^{14} \cdot \mathrm{CO}_{2} \text { permeance } \\
\left(\mathrm{m}^{3} / \mathrm{m}^{2} \cdot \mathrm{s} \cdot \mathrm{Pa}\right)\end{array}$} \\
\hline & & $0 \% \mathrm{RH}$ & $90 \% \mathrm{RH}$ & $0 \% \mathrm{RH}$ & $90 \% \mathrm{RH}$ \\
\hline PP & 30 & $13.54 \pm 0.15$ & $15.06 \pm 0.20$ & $117.80 \pm 3.60$ & $101.90 \pm 1.50$ \\
\hline PP+EVOH & $30 / 1.15$ & $0.085 \pm 0.003$ & $10.17 \pm 0.08$ & $0.78 \pm 0.02$ & $24.67 \pm 0.22$
\end{tabular}


assays with $\mathrm{CO}_{2}$. Effect of the agents in the barrier properties of the coatings should be negligible since, plasticization should not be expected from the addition of apolar substances to a polar matrix and agents with double functionality which could promote chain cross-linking are not present.

Considering that only part of the bag surface was coated, the effect of the coating on the transmission rate was even lower. An estimation of the $\mathrm{O}_{2}(\mathrm{OER})$ and $\mathrm{CO}_{2}$ exchange rates $\left(\mathrm{CO}_{2} \mathrm{ER}\right)$ for the entire bag at the beginning of storage can be obtained by the use of the permeation equation for a bag constituted by two different materials, considering the permeance values for each film $\left(\mathrm{P}_{\mathrm{i}}\right)$, the film surface $\left(\mathrm{A}_{\mathrm{i}}\right)$ and the pressure gradient $(\triangle \mathrm{pi})$ :

$$
\begin{aligned}
& \operatorname{OER}=\sum_{i=1}^{n}\left(\mathrm{P}_{i}\left(\mathrm{O}_{2}\right) \cdot \mathrm{A}_{i}\right) \cdot \Delta \mathrm{p}\left(\mathrm{O}_{2}\right) ; \quad C O_{2} E R=\sum_{i=1}^{n}\left(\mathrm{Pi}_{i}\left(\mathrm{CO}_{2}\right) \cdot \mathrm{A}_{i}\right) \cdot \Delta p\left(\mathrm{CO}_{2}\right) \\
& \operatorname{OER}(\text { coated })=2.3 \cdot 10^{-10} \frac{\mathrm{m}^{3}}{\mathrm{~s}} ; \operatorname{OER}(\mathrm{CONTROL})=2.9 \cdot 10^{-10} \frac{\mathrm{m}^{3}}{\mathrm{~s}} \\
& \mathrm{CO}_{2} E R(\text { coated })=6.5 \cdot 10^{-10} \frac{\mathrm{m}^{3}}{\mathrm{~s}} ; \mathrm{CO}_{2} E R(C O N T R O L)=1.3 \cdot 10^{-9} \frac{\mathrm{m}^{3}}{\mathrm{~s}}
\end{aligned}
$$

In technological units, the gas exchange rates for a finished bag are: 25 and 20 cc/day of $\mathrm{O}_{2}$ and 112 and $56 \mathrm{cc} /$ day of $\mathrm{CO}_{2}$ for the CONTROL and coated sample, respectively.

Table 2 shows the evolution of the head space composition for the three samples tested. In all cases, the $\mathrm{O}_{2}$ was rapidly consumed as the product respired and there was a corresponding increase in $\mathrm{CO}_{2}$ levels. The presence of the EVOH coating in the active packaging did not significantly influence the headspace composition during the storage period. EVOH generally acts as a high barrier material to gases when dry. However, when in contact with fresh vegetables, the EVOH layer becomes humid and the barrier properties are dramatically reduced. Thus the EVOH layer becomes permeable and the whole package behaves similarly to the reference one. Although the differences were not significant, it appears that the packages containing CITRAL as active agent had a lower $\mathrm{CO}_{2}$ content than the other two samples, as if the CITRAL had an effect on the reduction in the respiration rate of the salad.

\subsection{Mechanical properties}

The mechanical parameters ( $\sigma \mathrm{m}, E$ and $\varepsilon$ b) of the CONTROL and treated films conditioned at 50\% RH are shown in Table 3. As can be seen, the application of the $\mathrm{EVOH}$ coating results in an increase in the tensile resistance of the PP films and a reduction in the elongation at break. This effect can be explained as a consequence of the different morphology of the two materials. PP is a material with a glass transition temperature below room temperature, whilst EVOH is a semicrystalline glassy copoly-

Table 2. Atmospheric composition $\left(\% \mathrm{O}_{2}\right.$ and $\left.\mathrm{CO}_{2}\right)$ of headspace in mixed salad packages manufactured with the control film and the active films at different storage times.

Day 1

Day 4

Day 8

\begin{tabular}{rcccccc}
\hline & $\mathrm{O}_{2}$ & $\mathrm{CO}_{2}$ & $\mathrm{O}_{2}$ & $\mathrm{CO}_{2}$ & $\mathrm{O}_{2}$ & $\mathrm{CO}_{2}$ \\
\hline CONTROL & $7.3 \pm 1.3 \mathrm{a}$ & $6.1 \pm 1.4 \mathrm{a}$ & $0.16 \pm 0.08 \mathrm{a}$ & $10.8 \pm 1.4 \mathrm{~b}$ & $0.03 \pm 0.01 \mathrm{a}$ & $15.1 \pm 1.1 \mathrm{~b}$ \\
\hline OEO & $5.5 \pm 1.5 \mathrm{a}$ & $6.8 \pm 1.3 \mathrm{a}$ & $0.06 \pm 0.03 \mathrm{a}$ & $11.4 \pm 1.7 \mathrm{~b}$ & $0.02 \pm 0.01 \mathrm{a}$ & $15.5 \pm 1.4 \mathrm{~b}$ \\
\hline CITRAL & $6.5 \pm 1.5 \mathrm{a}$ & $6.3 \pm 1.0 \mathrm{a}$ & $0.25 \pm 0.12 \mathrm{a}$ & $9.0 \pm 1.0 \mathrm{a}$ & $0.02 \pm 0.01 \mathrm{a}$ & $11.8 \pm 1.2 \mathrm{a}$ \\
\hline
\end{tabular}

a, b: the letters are indicative of significance 
mer, therefore more rigid and more fragile than PP. No effect was observed as a result of incorporation of the agent in the EVOH layer and the corona-treated. The effect of the coating application would be severely diminished in humid conditions as a con- sequence of the plasticization of the EVOH coating. Unfortunately, no measurement could be carried out in these environmental conditions (90\% RH and room temperature) with the equipment used.

Table 3. Mechanical properties of films fested at 50\% RH.

\begin{tabular}{rccc}
\multicolumn{1}{c}{ Sample } & $\boldsymbol{\sigma m}(\mathbf{M P a})$ & $\boldsymbol{\varepsilon b}(\%)$ & $\boldsymbol{E}(\mathbf{M P a})$ \\
\hline PP & $125.65 \pm 5.76 \mathrm{a}$ & $356.65 \pm 29.74 \mathrm{~b}$ & $658.48 \pm 41.40 \mathrm{a}$ \\
\hline CONTROL & $205.67 \pm 42.56 \mathrm{~b}$ & $303.76 \pm 38.14 \mathrm{a}$ & $1729.02 \pm 90.55 \mathrm{~b}$ \\
\hline OEO & $211.89 \pm 10.32 \mathrm{~b}$ & $274.44 \pm 27.88 \mathrm{a}$ & $1746.98 \pm 35.65 \mathrm{~b}$ \\
\hline CITRAL & $213.64 \pm 9.29 \mathrm{~b}$ & $281.51 \pm 26.29 \mathrm{a}$ & $1754.90 \pm 82.94 \mathrm{~b}$
\end{tabular}

бm: Maximum tensile strength. $\varepsilon$ b: Elongation at break. E: Young's modulus. Reported values are means of 6 replicates \pm standard deviation.

$\mathrm{a}, \mathrm{b}$ : the letters are indicative of significance

\subsection{Antimicrobial activity of active films on microflora of minimally processed sa- lads}

The samples were subjected to microbiological analysis on the $1^{\text {st }}, 4^{\text {th }}$ and $8^{\text {th }}$ days of refrigerated storage. The results of microbiological counts of minimally processed salad samples are shown in Table 4.

On the $1^{\text {st }}$ day of storage, the enterobacteria counts for "four season salad" packaged in the active samples showed a significant decrease in comparison with the control sample. OEO and CITRAL samples had reductions of 1.38 log and 2.13 log respectively. With storage time, there was no measurable effect. It should be noted that high levels of enterobacteria are common in raw vegetables and it is reported that they are not used to indicate the microbiological quality of fresh vegetables [18].

The total aerobic counts were reduced only on the $1^{\text {st }}$ day of storage; OEO films reduced count by $1.08 \log$ and CITRAL films $1.23 \mathrm{log}$. The aerobic population increased to 5 log in all cases on the $4^{\text {th }}$ day and to 6 log in all cases at the end of storage.

Table 4 also shows the antifungal effecti- veness of the active films. The active compounds appear to be most effective on day 1 . OEO and CITRAL samples had a reduction of about $2 \mathrm{log}$. At the end of the storage period, the coatings produced an inhibition of about $0.5 \mathrm{log}$. The role of yeasts and moulds in the spoilage of vegetables is not well studied, although they have been implicated in the spoilage of fermented vegetable products $[19,20]$ and could cause off-odours and visual defects in minimally processed vegetables. Some authors [21] have pointed out the possible health problems associated with the presence of moulds in fruits and vegetables. Their growth could be related with the quality of the salad and acceptability by the consumer.

The reduction of lactic acid bacteria was more significant for the films containing CITRAL, about $2 \log$ on the $1^{\text {st }}$ day of storage, and about 1 log reduction was observed on the $4^{\text {th }}$ and $8^{\text {th }}$ days. OEO films showed an inhibition of $0.5 \log$ on day 1 , which was just maintained during storage.

With respect to psychrotrophic bacteria that are able to grow at refrigerator temperature, the samples packaged with the OEO and CITRAL films showed an inhibition of approximately 2 log at the beginning of sto- 
rage at $4^{\circ} \mathrm{C}$. However, there was no measurable effect after 8 days of storage, because psychrotrophic bacteria counts increased at $8{ }^{\circ} \mathrm{C}$ and they reached a stationary phase before the day of analysis (data not shown).

It can be concluded that these active films provided inhibition of microflora bacteria in the first stages of the storage period, when the concentration of the agent in the package headspace was higher and the storage temperature lower. The intrinsic properties of the food (fat/protein/water content, antioxidants, preservatives, $\mathrm{pH}$, salt and other additives) and the extrinsic determinants (temperature, packaging in vacuum/gas/air, characteristics of microorganisms) can also influence bacterial sensitivity [22]. The antimicrobial activity of essential oil benefits from a decrease in storage temperature and the low fat content in salads. It is generally supposed that the high levels of fat in foodstuffs protect the bacteria from the action of the EO [22, 23], therefore these factors could contribute to the successful results observed with essential oils [15].

CITRAL, which appears to be more effective than OEO, has already been successfully used for the inhibition of yeast growth and lactic acid bacteria in fruit-based salads [24].

Table 4. Enumeration of microbial population in mixed salad packages: enterobacteria, total aerobic, yeasts and moulds, lactic acid bacteria and psychrotrophic bacteria on $1^{\text {st }}, 4^{\text {th }}$ and $8^{\text {th }}$ days of storage.

\section{ENTEROBACTERIA}

\begin{tabular}{|c|c|c|c|c|c|c|}
\hline \multirow[t]{2}{*}{ Coating } & \multicolumn{2}{|c|}{ Day 1} & \multicolumn{2}{|c|}{ Day 4} & \multicolumn{2}{|c|}{ Day 8} \\
\hline & Log & Reduction & $\log$ & Reduction & Log & Reduction \\
\hline CONTROL & $4.98 \pm 0.65 c$ & & $4.00 \pm 0.00 a$ & & $4.87 \pm 0.00 b$ & \\
\hline OEO & $3.60 \pm 0.38 b$ & -1.38 & $4.01 \pm 0.14 a$ & - & $4.73 \pm 0.38 a$ & - \\
\hline CITRAL & $2.85 \pm 0.09 a$ & -2.13 & $3.96 \pm 0.50 a$ & - & $4.90 \pm 0.03 b$ & - \\
\hline
\end{tabular}

TOTAL AEROBIC

\begin{tabular}{rcccccl}
\hline CONTROL & $5.18 \pm 0.36 \mathrm{c}$ & \multicolumn{3}{c}{$5.13 \pm 0.02 \mathrm{a}$} & \multicolumn{1}{c}{$6.17 \pm 0.03 \mathrm{c}$} & \\
\hline OEO & $4.10 \pm 0.15 \mathrm{~b}$ & -1.08 & $5.03 \pm 0.23 \mathrm{a}$ & -0.10 & $5.89 \pm 0.18 \mathrm{a}$ & - \\
\hline CITRAL & $3.95 \pm 0.11 \mathrm{a}$ & -1.23 & $5.23 \pm 0.07 \mathrm{a}$ & - & $6.05 \pm 0.07 \mathrm{~b}$ & - \\
\hline
\end{tabular}

YEASTS AND MOULDS

\begin{tabular}{rcccccc}
\hline CONTROL & $5.54 \pm 0.12 \mathrm{c}$ & \multicolumn{3}{c}{$4.28 \pm 0.03 \mathrm{c}$} & \multicolumn{3}{c}{$6.05 \pm 0.16 \mathrm{~b}$} \\
\hline OEO & $3.76 \pm 0.25 \mathrm{~b}$ & -1.77 & $3.88 \pm 0.11 \mathrm{~b}$ & -0.40 & $5.36 \pm 0.32 \mathrm{a}$ & -0.69 \\
\hline CITRAL & $3.52 \pm 0.53 \mathrm{a}$ & -2.02 & $3.68 \pm 0.00 \mathrm{a}$ & -0.60 & $5.41 \pm 0.04 \mathrm{a}$ & -0.64 \\
\hline \multicolumn{5}{c}{ LACTIC ACID BACTERIA }
\end{tabular}

\begin{tabular}{rrrrrrr}
\hline CONTROL & $4.20 \pm 0.14 \mathrm{c}$ & \multicolumn{3}{c}{$6.24 \pm 0.08 \mathrm{c}$} \\
\hline OEO & $3.53 \pm 0.51 \mathrm{~b}$ & -0.67 & $3.71 \pm 0.28 \mathrm{~b}$ & -0.34 & $5.80 \pm 0.20 \mathrm{~b}$ & -0.44 \\
\hline CITRAL & $2.00 \pm 0.00 \mathrm{a}$ & -2.20 & $3.13 \pm 0.16 \mathrm{a}$ & -0.91 & $5.05 \pm 0.15 \mathrm{a}$ & -1.19 \\
\hline
\end{tabular}

PSYCHROTROPHIC

\begin{tabular}{rrrrrrr}
\hline CONTROL & $5.74 \pm 0.55 \mathrm{c}$ & \multicolumn{3}{c}{$6.11 \pm 0.06 \mathrm{~b}$} & \\
\hline OEO & $4.00 \pm 0.01 \mathrm{~b}$ & -1.75 & $4.95 \pm 0.28 \mathrm{a}$ & -0.16 & $5.88 \pm 0.12 \mathrm{a}$ & -0.23 \\
\hline CITRAL & $3.74 \pm 0.24 \mathrm{a}$ & -2.01 & $4.93 \pm 0.11 \mathrm{a}$ & -0.18 & $5.82 \pm 0.60 \mathrm{a}$ & -0.28 \\
\hline
\end{tabular}


CITRAL can also be used to prolong the shelf-life of "four season salads". In this study with real foodstuffs, essential oil produced lower effects than in another test carried out in vitro in our laboratory [6], which can be attributed to partial sorption of the agent in the food, with a subsequent reduction in concentration in the vapour phase. A reduction in the antimicrobial activity of essential oils due to the nature of the food matrix has been documented [6, 15, 24, 25]. Therefore, higher concentrations of plant essential oils are generally required when added to food [26]. However, the application of essential oils in food may be limited by the changes they produce in the organoleptic and textural quality of the food or interactions of these compounds with food components [27].

\subsection{Sensory analyses}

The organoleptic effect of oils is one of the most important factors that limit their application to real food products as antimicrobial agents, a property widely described in in vitro tests [24]. Their use may have a significant sensory impact that could result in non-acceptance by the consumer. For this reason, sensory analyses were carried out on the "four season salads" packaged with the films developed.

The effects of the addition of different kinds of agents on the sensory properties of smell acceptability, visual appearance, texture and general acceptability were studied. On the $1^{\text {st }}$ day of storage, the assessors perceived significant differences in odour acceptability, depending on the agents (OEO or CITRAL), in comparison with the CONTROL samples, as shown in Figures 2-4. In terms of visual appearance, no significant differences were observed between the samples. This can be explained by the fact that 1 storage day is not enough to cause deterioration of the sample.
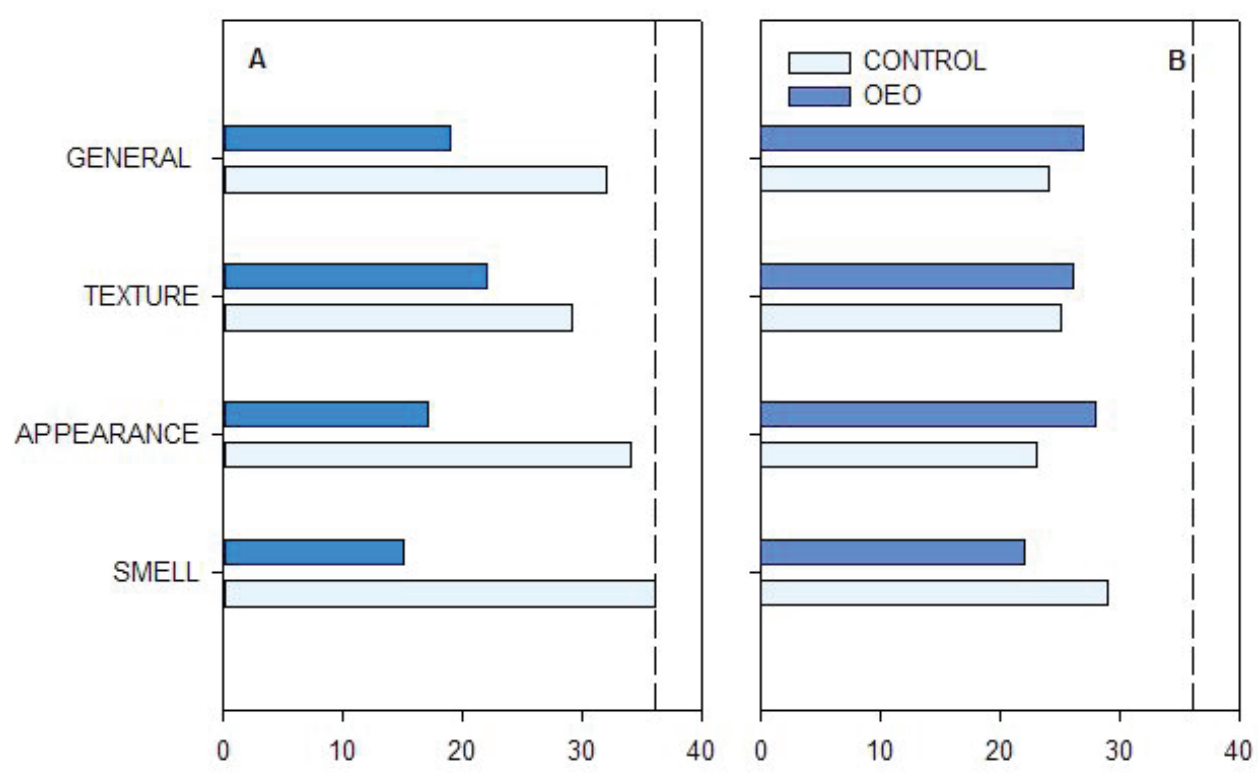

Number of judges

Figure 2. Sensory evaluation of the differences between the smell, appearance, texture and general preference of CONTROL and OEO on the $1^{\text {st }}(\mathrm{A})$ and $8^{\text {th }}(\mathrm{B})$ day of storage. The dashed line indicates the minimum number of responses for which the difference is significant. 


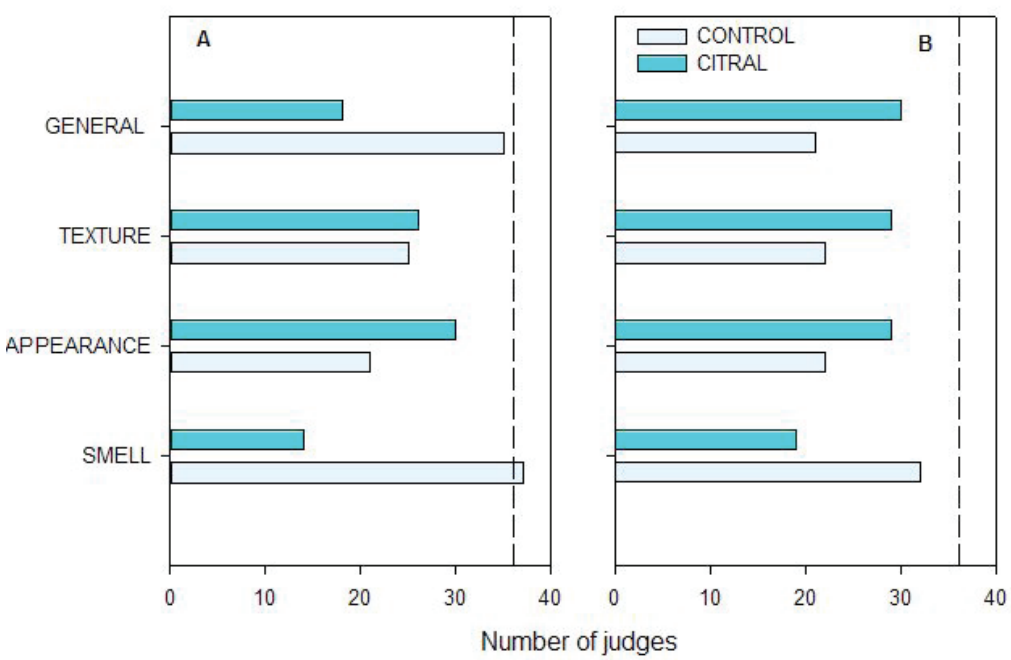

Figure 3. Sensory evaluation of the differences between the smell, appearance, texture and general preference of CONTROL and CITRAL on the $1^{\text {st }}(\mathrm{A})$ and $8^{\text {th }}(\mathrm{B})$ day of storage. The dashed line indicates the minimum number of responses for which the difference is significant.

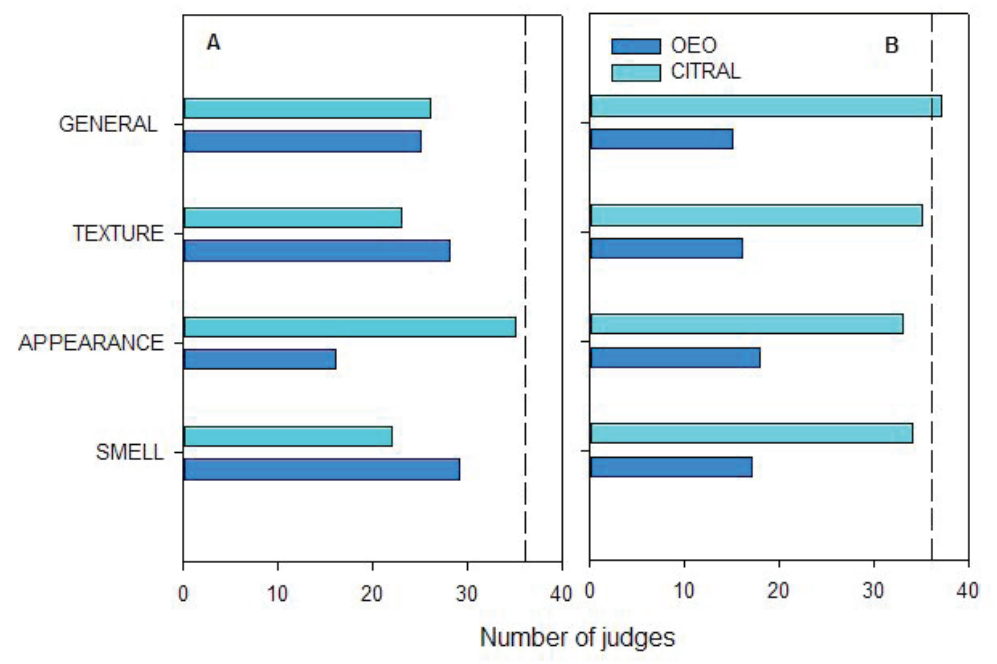

Figure 4. Sensory evaluation of the differences between the smell, appearance, texture and general preference of OEO and CITRAL on the $1^{\text {st }}(\mathrm{A})$ and $8^{\text {th }}(\mathrm{B})$ day of storage. The dashed line indicates the minimum number of responses for which the difference is significant.

On the $8^{\text {th }}$ day of storage, no significant differences were recorded for smell, visual appearance, texture and general acceptability when the control was compared with OEO or CITRAL. Only differences between oregano essential oil and citral were found by the judges. The samples with CITRAL were clearly preferred on day 8 of storage.

OEO and CITRAL resulted in a pleasant flavour, compatible with final products. This is a prerequisite for the use of essential oils in foods for antimicrobial purposes. 


\section{CONCLUSIONS}

In conclusion, the use of active packaging based on the release of volatile antimicrobials combined with modified atmosphere packaging is an alternative technology to improve the microbiological and sensory stability of salad. The addition of the active EVOH coating did not substantially affect the functional properties of the packaging film, since neither barrier nor mechanical properties had unacceptable values. Nevertheless, the packaged product did produce improved microbial stability when active films were used, especially with regard to growth inhibition of enterobacteria, lactic acid and psychrotrophic bacteria, and yeasts and moulds at the beginning of storage. The sensory studies showed that the active agent release resulted in a non-typical smell which led the judges to prefer the control samples, whereas after long-term storage the samples in active bags were preferred, especially the one containing citral. The results of the present work demonstrated that packaging of minimally processed salad in MAP bags manufactured with PP/EVOH with essential oils is an appropriate way to reach a balance between the demand for microbial safety and consumer acceptability.

\section{Acknowledgements}

Authors thank the financial support of the Spanish Ministry of Economy and Competitiveness (Project AGL2009-08776 and V.M-G fellowships), EU (Nafispack project 212544), Generalitat Valenciana (J.P.C. fellowship) and Mr. Karel Clapshaw (translation services). 


\section{REFERENCES}

[1] H. Froeder, C.G. Martins, K.L. Oliveira de Souza, M. Landgraf, B.D.G.M. Franco, M.T. Destro, Minimally processed vegetable salads: microbial quality evaluation, Journal of Food Protection, 70 (2007) 1277-1280.

[2] M.I. Santos, A. Cavaco, J. Gouveia, M.R. Novais, P.J. Nogueira, L. Pedroso, M. Ferreira, Evaluation of minimally processed salads commercialized in Portugal, Food Control, 23 (2012) 275-281.

[3] E. Carrasco, F. Perez-Rodriguez, A. Valero, R.M. Garcia-Gimeno, G. Zurera, Growth of Listeria monocytogenes on shredded, ready-to-eat iceberg lettuce, Food Control, 19 (2008) 487-494.

[4] G. Oms-Oliu, R. Martinez, R. Soliva-Fortuny, O. Martin-Belloso, Effect of superatmospheric and low oxygen modified atmospheres on shelflife extension of fresh-cut melon, Food Control, 19 (2008) 191-199.

[5] L. Sanchez-Gonzalez, M. Chafer, M. Hernandez, A. Chiralt, C. Gonzalez-Martinez, Antimicrobial activity of polysaccharide films containing essential oils, Food Control, 22 (2011) 1302-1310.

[6] V. Muriel-Galet, J.P. Cerisuelo, G. López-Carballo, M. Lara, R. Gavara, P. Hernández-Muñoz, Development of anticrobial films for microbiological control of packaged salad International Journal of Food Microbiology, (2012).

[7] C. Lopez-de-Dicastillo, J.M. Alonso, R. Catala, R. Gavara, P. Hernandez-Munoz, Improving the antioxidant protection of packaged food by incorporating natural flavonoids into ethylenevinyl alcohol copolymer (EVOH) films, Journal of Agricultural and Food Chemistry, 58 (2010) 10958-10964.

[8] C. Lopez-de-Dicastillo, R. Catala, R. Gavara, P. Hernandez-Munoz, Food applications of active packaging EVOH films containing cyclodextrins for the preferential scavenging of undesirable compounds, Journal of Food Engineering, 104 (2011) 380-386.
[9] C. Lopez-de-Dicastillo, M. Gallur, R. Catala, R. Gavara, P. Hernandez-Munoz, Immobilization of beta-cyclodextrin in ethylene-vinyl alcohol copolymer for active food packaging applications, Journal of Membrane Science, 353 (2010) 184-191.

[10] Virginia Muriel-Galet, Jose Pascual Cerisuelo, Gracia Lopez-Carballo, Marta Lara, Rafael Gavara and Pilar Hernandez-Munoz, Development of antimicrobial films for microbiological control of packaged salad, International Journal of Food Microbiology, (2012).

[11] F. Lopez-Galvez, M.I. Gil, P. Truchado, M.V. Selma, A. Allende, Cross-contamination of fresh-cut lettuce after a short-term exposure during pre-washing cannot be controlled after subsequent washing with chlorine dioxide or sodium hypochlorite, Food Microbiology, 27 (2010) 199-204.

[12] G. Lopez-Carballo, D. Cava, J.M. Lagaron, R. Catala, R. Gavara, Characterization of the interaction between two food aroma components, alpha-pinene and ethyl butyrate, and ethylene-vinyl alcohol copolymer (EVOH) packaging films as a function of environmental humidity, Journal of Agricultural and Food Chemistry, 53 (2005) 7212-7216.

[13] D. ASTM, Standard test method for tensile properties of thin plastic sheeting, in, In American Society for Testing Materials, 2009.

[14] H.J. MacFie, N. Bratchell, K. Greenhoff, L.V. Vallis, Designs to balance the effect of order of presentation and first-order carry-over effects in hall tests, Journal of Sensory Studies, 4 (1989) 129-148.

[15] S. Burt, Essential oils: their antibacterial properties and potential appliations in foods - a review, International Journal of Food Microbiology, 94 (2004) 223-253.

[16] M. Charai, M. Mosaddak, M. Faid, Chemical composition and antimicrobial activities of two aromatic plants: Origanum majorana L. and $\mathrm{O}$. compactum Benth, Journal of Essential Oil Research, 8 (1996) 657-664. 
[17] S. Aucejo, R. Catala, R. Gavara, Interactions between water and EVOH food packaging films, Food Science and Technology International/ Ciencia y Tecnologia de Alimentos Internacional, 6 (2000) 159-164.

[18] C. Little, D. Roberts, E. Youngs, J.d. Louvois, Microbiological quality of retail imported unprepared whole lettuces: a PHLS Food Working Group study, Journal of Food Protection, 62 (1999) 325-328.

[19] G. Fleet, Spoilage yeasts, CRC Critical Reviews in Biotechnology, 12 (1992) 1-44.

[20] M. Abadias, J. Usall, M. Anguera, C. Solson, I. Vinas, Microbiological quality of fresh, minimally-processed fruit and vegetables, and sprouts from retail establishments, International Journal of Food Microbiology, 123 (2008) 121-129.

[21] V.H. Tournas, Moulds and yeasts in fresh and minimally processed vegetables, and sprouts, International Journal of Food Microbiology, 99 (2005) 71-77.

[22] C.C. Tassou, E.H. Drosinos, G.J.E. Nychas, Effects of essential oil from mint (mentha-piperita) on Salmonella and Liseteria-monocytogenes in model food systems at 4-degrees and 10-degrees-C Journal of Applied Bacteriology, 78 (1995) 593-600.

[23] V.A. Pandit, L.A. Shelef, Sensitivity of Listeria-monocytogenes to rosemary (rosmarinusofficialis l) Food Microbiology, 11 (1994) 57-63.

[24] N. Belletti, R. Lanciotti, F. Patrignani, F. Gardini, Antimicrobial efficacy of citron essential oil on spoilage and pathogenic microorganisms in fruit-based salads, Journal of Food Science, 73 (2008) M331-M338.

[25] R. Lanciotti, A. Gianotti, F. Patrignani, N. Belletti, M.E. Guerzoni, F. Gardini, Use of natural aroma compounds to improve shelf-life and safety of minimally processed fruits, Trends in Food Science \& Technology, 15 (2004) 201-208.
[26] J. Gutierrez, C. Barry-Ryan, P. Bourke, The antimicrobial efficacy of plant essential oil combinations and interactions with food ingredients, International Journal of Food Microbiology, 124 (2008) 91-97.

[27] F. Devlieghere, K. Francois, K.M. Vereecken, A.H. Geeraerd, J.F.v. Impe, J. Debevere, Effect of chemicals on the microbial evolution in foods, Journal of Food Protection, 67 (2004) 1977-1990. 


\section{CHAPTER II.}

\section{DEVELOPMENT OF}

\section{ANTIMICROBIAL FILMS WITH NON-VOLATILE COMPOUNDS}

ARTICLE 3.

ANTIMICROBIAL FOOD PACKAGING FILM BASED ON THE RELEASE OF LAE FROM EVOH

ARTICLE 4.

CHARACTERIZATION OF ETHYLENE-VINYL ALCOHOL COPOLYMER CONTAINING LAURIL ARGINATE (LAE) AS MATERIAL FOR ACTIVE ANTIMICROBIAL FOOD PACKAGING

ARTICLE 5.

ANTIMICROBIAL EFFECTIVENESS OF LAUROYL ARGINATE INCORPORATED INTO ETHYLENE VINYL ALCOHOL COPOLYMERS TO EXTEND THE SHELF-LIFE OF CHICKEN STOCK AND SURIMI STICKS

ARTICLE 6.

ANTIMICROBIAL PROPERTIES OF ETHYLENE-VINYL ALCOHOL/ EPSILON-POLYLYSINE AND THEIR APPLICATION IN SURIMI PRESERVATION 



\section{ANTIMICROBIAL FOOD PACKAGING FILM BASED ON THE RELEASE OF LAE FROM EVOH}

Virginia Muriel-Galet', Gracia López-Carballo', Rafael Gavara* and Pilar Hernández-Muñoz

International Journal of Food Microbiology 2012, 157, 329-244 


\section{ABSTRACT}

The aim of this work was to develop antimicrobial films for active packaging applications containing the natural antimicrobial compound LAE (ethyl lauroyl arginate) in EVOH copolymers with different mol \% ethylene contents (i.e. EVOH29 and EVOH44). EVOH29 and EVOH44 films were made by casting and incorporating $0.25 \%, 1 \%, 5 \%$, and $10 \%$ LAE in the film forming solution (w/w with respect to polymer weight). Previously, the minimum inhibitory concentration (MIC) and the minimum bactericidal concentration (MBC) of LAE against L. monocytogenes, E. coli, and S. enterica were determined by a microdilution assay. The antimicrobial activity of the resulting films was tested in vitro against these microorganisms in liquid culture media. The activity of the films was also evaluated over time. The results showed that films containing 5\% and 10\% LAE produced total growth inhibition and viable counts decreased with $0.25 \%$ and $1 \%$ LAE. Finally, the effectiveness of the films was tested by applying them to an infant formula milk inoculated with L. monocytogenes and S. enterica and stored for 6 days at $4{ }^{\circ} \mathrm{C}$. The application of films with LAE to infant formula milk inoculated with L. monocytogenes reduced at the end of storage period about 4 log in case of 10\% LAE and with S. enterica reduced 3.74 log and 3.95 log with EVOH29 5\% and 10\% respectively and EVOH44 5\% and 10\% LAE reduced $1 \mathrm{log}$ and $3.27 \mathrm{log}$ respectively at the end of storage. The antimicrobial capacity of EVOH29 films was greater than that of EVOH44 films in all the cases tested. In general, the films were more effective in inhibiting the growth of L. monocytogenes than S. enteri$\mathrm{ca}$, this inhibition being more acute at the end of the storage time.

Keywords: antimicrobial food packaging, EVOH, LAE, L. monocytogenes, E. coli, S. enterica. 


\section{INTRODUCTION}

Recent foodborne microbial outbreaks and consumer demand to minimize chemical additives in food are driving a search for innovative ways to inhibit microbial growth in foods while maintaining quality, freshness, and safety. New techniques such as modified atmosphere, high pressure, irradiation, etc. are being developed. Antimicrobial packaging is another option to provide increased food safety and quality, a technology that can be used with those mentioned previously in the so-called hurdles technology [1].

Antimicrobials can be added to food formulations directly or by slow release from packaging materials. Direct addition of antimicrobials to foods results in an immediate reduction of bacterial populations but may not prevent the recovery of injured cells or the growth of cells that were not destroyed by direct addition if residues of the antimicrobial are rapidly depleted [2]. Antimicrobial packaging is a technology that inhibits or retards the proliferation of microorganisms in foods, thus extending the shelf life of the product [3]. The application of antimicrobial films allows for migration of the antimicrobial to the coating surface and provides a continuous antimicrobial effect on the food during extended exposure. Use of polymers as carriers of antimicrobials not only permits controlled release of these antimicrobials but also prevents dramatic reductions in their antimicrobial activities due to their affinity for food particles and inactivation by components in foods. It also reduces the amount of active agent required, satisfying consumer demand for fewer additives.

Several compounds have been proposed for antimicrobial activity in food packaging, including essential oils, enzymes, and organic acids such as lauric arginate (LAE, (95\% of ethyl-N-dodecanoyl-L-arginate hydrochloride)). LAE is a cationic surfactant, a derivative of lauric acid, L-arginine, and ethanol [4]. The preparation and application of this product is described in several patent applications [5-7].

LAE is one of the most potent food antimicrobial agents, with a broad spectrum of antimicrobial activity [8], and it has been classified as GRAS (Generally Recognized as Safe) and food preservative at concentration up to 200 ppm by the Food and Drug Administration (FDA) [8]. LAE is hydrolyzed in the human body and quickly broken into natural components. Several toxicological studies were carried out with animals and human by The Huntingdon Life Science although these studies did not involved YOPIs (young, old, pregnant and immune-compromised) [4]. The high antimicrobial activity of LAE has been attributed to its action on the cytoplasmic membranes of microorganisms, where it alters their metabolic processes without causing cellular lysis [7]. Furthermore, LAE tends to concentrate in the aqueous phase of products, where most bacterial action occurs, because of its low oil-water equilibrium partition coefficient $[4,8]$. LAE has been verified to be nontoxic and is metabolized rapidly to naturally occurring amino acids, mainly arginine and ornithine, after consumption [4]. To the date, the use of LAE as an antimicrobial agent in food products has been well reported in various studies [9-12]. However, limited information is available concerning antimicrobial activity when LAE is applied via a packaging system [13].

In this work, two ethylene-vinyl alcohol copolymers (EVOH) with different mol 
\% ethylene contents (i.e. EVOH29 and EVOH44) were used as matrices to incorporate the antimicrobial compound LAE. $\mathrm{EVOH}$ is a packaging material commonly used to provide high oxygen barrier properties. The hydrophilic nature of $\mathrm{EVOH}$ makes this polymer very sensitive to water, and its barrier properties are greatly affected by moisture [14]. Furthermore, EVOH materials have been used recently as matrices for the development of active packaging systems, where the polymer protects the active agents during storage and triggers their activity on exposure to a humid environment (the food product) [15-17]. This copolymer is composed of two segment chains: one, olefinic and hydrophobic, comes from ethylene, and the other, with a hydroxyl substituent, presents hydrophilic behavior. Therefore, the higher the percentage of ethylene, the less polar and less water sensitive the copolymer is [18]. In this study EVOH29 and EVOH44, containing 29\% mol and 44\% mol ethylene, were selected to check the effect of matrix polarity on the antimicrobial behavior of active materials.

For many food products, no other antimicrobial intervention is used other than refrigeration following the packaging process. Antimicrobial packaging provides an additional and final barrier that can prevent the growth of foodborne pathogens. S. enterica comes from postpasteurization contamination and L. monocytogenes could survive pasteurization [19, 20]. The characteristics of infant formula ( $\mathrm{pH}$ close to neutrality, large presence of nutrients) could favor the increase in viable counts of L. monocytogenes and refrigeration alone is not sufficient to prevent its growth in foods, since the mean minimum growth temperature was found to be $1.1^{\circ} \mathrm{C}$, with a range of 0.5 to $3{ }^{\circ} \mathrm{C}$ [21]. Thus, infant milk is a product that could benefit from antimicrobial packaging.

The aims of this work were to develop antimicrobial films for food packaging applications incorporating the antimicrobial compound LAE in EVOH (i.e. EVOH29 and EVOH44), to determine the ability of the films to inhibit the growth of L. monocytogenes, E. coli, and S. enterica in vitro, and to investigate the antimicrobial effect to inactivate pathogens in an infant formula, in order to reduce the great risk of microbial contamination.

\section{MATERIALS AND METHODS}

\subsection{Chemicals and reagents}

Ethylene vinyl alcohol copolymers with a 29\% ethylene molar content (EVOH29) and with a 44\% ethylene molar content (EVOH44) were kindly provided by The Nippon Synthetic Chemical Company (Osaka, Japan). 1-propanol was purchased from Sigma (Madrid, Spain). The antimicrobial LAE $\left(\mathrm{C}_{20} \mathrm{H}_{41} \mathrm{~N}_{4} \mathrm{O}_{3} \mathrm{Cl}\right)$ was provided by
Vedeqsa Grupo LAMIRSA (Terrassa, Barcelona, Spain). Water was obtained from a Milli-Q Plus purification system (Millipore, Molsheim, France).

\subsection{Film preparation}

The polymer EVOH29 was dissolved in a 1:1 (v:v) 1-propanol:Milli-Q water mixture at $50{ }^{\circ} \mathrm{C}$. EVOH44 was dissolved in a 2:1 (v:v) 
1-propanol:Milli-Q water mixture at $50{ }^{\circ} \mathrm{C}$. The solution was stirred for 30 min using a magnetic stirrer hotplate. LAE was added to the polymer solutions in proportions of $0.25 \%, 1 \%, 5 \%$, and $10 \%$ with respect to polymer content and stirred for $15 \mathrm{~min}$. Control films were obtained without LAE. $5 \mathrm{~mL}$ of the EVOH solution was spread over previously cleaned glass plates with the aid of a steel stud with a $100 \mu \mathrm{m}$ deep thread (LinLab Rioja, Logroño, Spain). The plates were placed in a drying tunnel equipped with a $2500 \mathrm{~W}$ heat source for 10 min until completely dry. Finally, the films were stored in glass desiccators with silica gel at $22^{\circ} \mathrm{C}$ until utilization. Film thickness was determined for each individual sample test with a Mitutoyo micrometer (Osaka, Japan) prior to testing, giving an average thickness of 15 $\pm 1 \mu \mathrm{m}$.

\subsection{In vitro assays: Antimicrobial film test}

\subsubsection{Bacterial cultures}

The following foodborne microbial strains were obtained from the Spanish Type Culture Collection (CECT, Valencia, Spain) and selected for use in the assays because of their relevance in the food industry: the Gram-positive bacterium Listeria monocytogenes CECT 934 (ATCC 19114); the Gram-negative bacteria Escherichia coli CECT 434 (ATCC 25922) and Salmonella enterica CECT 4300 (ATCC 13076). The strains were stored in Tryptone Soy Broth (TSB) purchased from Scharlab (Barcelona, Spain) with $20 \%$ glycerol at $-80{ }^{\circ} \mathrm{C}$ until needed. For experimental use, the stock cultures were maintained by regular subculture at $4{ }^{\circ} \mathrm{C}$ on slants of Tryptone Soy Agar (TSA) from Scharlab (Barcelona, Spain) and transferred monthly. Prior to each experiment, a loopful of each strain was transferred to 10 $\mathrm{mL}$ of TSB and incubated at $37^{\circ} \mathrm{C}$ for $18 \mathrm{~h}$ to obtain early stationary phase cells.

\subsubsection{Determination of MICsandMBCsagainst E. coli, L. monocytogenes, and S. enterica}

The minimum inhibitory concentration (MIC) and minimum bactericidal concentration (MBC) of LAE against L. monocytogenes, E. coli, and S. enterica strains were determined in TSB. $0.25 \mathrm{~g}$ of LAE was diluted in $250 \mathrm{~mL}$ of Milli-Q water to obtain a concentration of $1000 \mathrm{ppm}$, and then serial dilutions were made up in sterile TSB to study MIC and MBC. A control tube with Milli-Q water was used as a blank. Cell cultures of each microorganism in stationary phase, with an optical density of 0.9 at 600 $\mathrm{nm}$, were diluted in TSB and incubated at $37^{\circ} \mathrm{C}$ until the exponential phase, that is, an optical density of 0.2 at $600 \mathrm{~nm}\left(10^{5} \mathrm{CFU} /\right.$ $\mathrm{mL}) .100 \mu \mathrm{L}$ of approximately $10^{5} \mathrm{CFU} / \mathrm{mL}$ of each microorganism in exponential phase was inoculated in each test tube. The tubes were incubated at $37^{\circ} \mathrm{C}$ for $24 \mathrm{~h}$. After the incubation period, the turbidity at 595 nm was measured with a UV-vis spectrophotometer (Agilent 8453 Spectroscopy System) using TSB as blank. Turbidity is an indication of microbial growth. $100 \mu \mathrm{L}$ from each tube was plated and incubated at $37^{\circ} \mathrm{C}$ for $24 \mathrm{~h}$ [22]. The lowest LAE concentration that inhibited the pathogen microorganisms was reported as the MIC. The MBC was the lowest concentration at which bacteria failed to grow in TSB and were not culturable after plating onto TSA. These definitions have been established by other workers [23].

\subsubsection{Antimicrobial activity of EVOH films with LAE}

$0.25 \mathrm{~g}$ of each film was placed in a glass bottle containing $10 \mathrm{~mL}$ of TSB. Cell cultures of each microorganism in stationary phase, with an optical density of 0.9 at 600 $\mathrm{nm}$, were diluted in TSB and incubated at $37^{\circ} \mathrm{C}$ until the exponential phase, that is, an optical density of 0.2 at $600 \mathrm{~nm}\left(10^{5}\right.$ $\mathrm{CFU} / \mathrm{mL}$ ). Aliquots containing $100 \mu \mathrm{L}$ of microorganism in exponential phase were transferred to the samples and incubated at $37^{\circ} \mathrm{C}$ for $24 \mathrm{~h}$. Depending on the turbidity of the tubes, serial dilutions with peptone 
water were made and plated in Petri dishes with $15 \mathrm{~mL}$ of TSA culture medium. Colonies were counted after incubation at $37^{\circ} \mathrm{C}$ for $24 \mathrm{~h}$.

\subsubsection{Antimicrobial activity of LAE films over time}

An experiment was designed to determine the effect of the immersion time of the film in the growth medium on its antimicrobial activity at $4{ }^{\circ} \mathrm{C}$. In brief, $0.25 \mathrm{~g}$ of film was immersed in $10 \mathrm{~mL}$ of TSB for 5 , 30, 90, 180, 240, and $1440 \mathrm{~min}$. After the corresponding time, the films were removed from the solution and $100 \mu \mathrm{L}$ of each microorganism in exponential phase $\left(10^{5}\right.$ $\mathrm{CFU} / \mathrm{mL}$ ) was inoculated into the tubes and incubated at $37^{\circ} \mathrm{C}$ for $24 \mathrm{~h}$. Depending on the turbidity of the tubes, serial dilutions with peptone water were made and plated in Petri dishes with $15 \mathrm{~mL}$ of TSA culture medium. Colonies were counted after incubation at $37{ }^{\circ} \mathrm{C}$ for $24 \mathrm{~h}$. Counts were performed in triplicate.

Separately, tubes with $10 \mathrm{~mL}$ of TSB and $0.25 \mathrm{~g}$ of film were stored for 5 days at $4^{\circ} \mathrm{C}$, after which the films were removed and $100 \mu \mathrm{L}$ of microorganism in exponential phase was transferred to the liquid medium and incubated at $37^{\circ} \mathrm{C}$ for $24 \mathrm{~h}$. Depending on the turbidity of the tubes, serial dilutions with peptone water were made and plated in Petri dishes with $15 \mathrm{~mL}$ of TSA culture medium. Colonies were counted after incubation at $37^{\circ} \mathrm{C}$ for $24 \mathrm{~h}$.

\subsection{In vivo assays: efficacy of LAE films against $L$. monocytogenes and $S$. enterica in an infant formula}

Antimicrobial activity against L. monocytogenes and S. enterica of films with 5\% and 10\% LAE was tested in an infant formula. Sterilized tubes were prepared with $10 \mathrm{~mL}$ of infant formula in sterilized conditions and $0.25 \mathrm{~g}$ of each antimicrobial film sample was inserted. Films without antimicrobial compound were used as a control. Then 100 $\mu \mathrm{L}$ of pathogen microorganism in exponential phase $\left(10^{5} \mathrm{CFU} / \mathrm{mL}\right)$ was inoculated. The tubes were stored for 6 days at $4{ }^{\circ} \mathrm{C}$.

Analyses were performed on the $2^{\text {nd }}$ and $6^{\text {th }}$ days of storage. Serial dilutions were carried out and plated on selective mediums: Palcam Listeria Selective Agar for L. monocytogenes and Brilliant Green Agar for S. enterica (Scharlab, Barcelona, Spain). Colonies were counted after incubation at $37^{\circ} \mathrm{C}$ for $48 \mathrm{~h}$. Counts were performed in triplicate.

\subsection{Statistical analysis}

Controls with EVOH film without LAE were made in every experiment. Counts were performed in triplicate.

One-way and two-way analyses of variance were carried out using the SPSS $B$ computer program (SPSS Inc., Chicago, IL, USA). Differences in pairs of mean values were evaluated by the Tukey test for a confidence interval of 95\%. Data are represented as mean \pm standard deviation.

\section{RESULTS AND DISCUSSION}

EVOH films (EVOH29 and EVOH44) with O\% (CONTROL), 0.25\%, 1\%, 5\%, and 10\% LAE were produced by casting. All films were transparent and without disconti- nuities, with a thickness of approximately $15 \mu \mathrm{m}$. Films were stored in dry conditions until tested, to maintain stability [15-17]. 
3.1 Determination of MICs and MBCs against L. monocytogenes, E. coli, and $S$. enterica

The bactericidal effect of LAE against $L$. monocytogenes, E. coli, and S. enterica was studied. The MIC and MBC values of LAE for the various bacteria are included in Table 1 . The growth of L. monocytogenes, $E$. coli, and S. enterica strains was inhibited by LAE at concentrations of 7, 20, and 10 ppm in TSB, respectively. The LAE MBCs for the same microorganisms were 12, 32, and $16 \mathrm{ppm}$, slightly higher than the MICs. The MIC values for LAE were different from those reported in the literature using strains of L. monocytogenes and S. enterica in liquid media $[7,12,24]$, reflecting the di- fferences in media composition, methodology, and strains of bacteria used. The antimicrobial activity of LAE is based on the disruption and instability of the plasma membrane [7].

LAE is slightly more active against Grampositive bacteria than against Gram-negative. Gram-negative organisms have a greater defense system and are less susceptible to the action of antibacterials since they possess an outer membrane surrounding the cell wall that restricts diffusion of hydrophobic compounds through its lipopolysaccharide covering [25]. This higher resistance of Gram-negative bacteria has also been observed with other antimicrobial compounds [26, 27, 28].

Table 1. Minimum inhibitory concentration (MIC) and minimum bactericidal concentration (MBC) of LAE against L. monocytogenes, E. coli, and S. enterica.

\begin{tabular}{ccc} 
& MIC LAE (ppm) & MBC LAE $(\mathrm{ppm})$ \\
\hline L. monocytogenes & 7 & 12 \\
\hline E. coli & 20 & 32 \\
\hline S. enterica & 10 & 16 \\
\hline
\end{tabular}

\subsection{Antimicrobial activity of EVOH films with LAE}

The antimicrobial activity of the films was tested against Gram-positive bacterium L. monocytogenes and Gram-negative bacteria E. coli and S. enterica. Table 2 shows the results for EVOH29. The films with 5 and 10\% LAE produced total inhibition of growth against all the microorganisms tested. 1\% LAE produced total inhibition against L. monocytogenes and reduced the growth of E. coli by about $4 \log$ and $S$. enterica by 5.31 log. 0.25\% LAE produced a reduction of 3.13 log against L. monocytogenes, 2.20 log for E. coli, and 2.37 against S. enterica.

As shown in Table 3, EVOH44 films with 5 and 10\% LAE produced total inhibition of growth against all the microorganisms tested.

The viable counts for all microorganisms decreased with $0.25 \%$ and 1\% LAE. 1\% LAE caused a growth reduction of 3.03 log against E. coli and 3.38 log against S. enteri$\mathrm{ca}$, while $0.25 \%$ LAE produced reductions of $1.44,2.40$, and 2.46 against L. monocytogenes, E. coli, and S. enterica, respectively.

A comparison between films shows (Tables 2 and 3) that the antimicrobial capacity of EVOH29 film was greater than that of EVOH44, especially in Gram-negative bacteria, less susceptible to LAE action. A comparison of these results with the MIC and $M B C$ values obtained for LAE are indicative of a partial release of the agent to the liquid media, since full deliver of the agent 
Table 2. Antimicrobial effectiveness against L. monocytogenes, E. coli, and S. enterica. EVOH29 films with $0.25 \%, 1 \%, 5 \%$, and 10\% LAE. Expressed as logarithm of colony forming units (Log(CFU) and log reduction value (LRV).
L. monocytogenes
E. coli
S. enterica

\begin{tabular}{|c|c|c|c|c|c|c|}
\hline & $\log (C F U)$ & LRV & $\log (C F U)$ & LRV & $\log (C F U)$ & LRV \\
\hline Control & $8.82 \pm 0.06$ & & $8.74 \pm 0.02$ & & $8.99 \pm 0.03$ & \\
\hline $10 \% \mathrm{LAE}$ & Total inhibitios & & Total inhibition & & Total inhibition & \\
\hline $5 \% \mathrm{LAE}$ & Total inhibitio & & Total inhibition & & Total inhibition & \\
\hline 1\% LAE & Total inhibitios & & $4.69 \pm 0.03$ & 4.05 & $3.68 \pm 0.71$ & 5.31 \\
\hline $0.25 \% \mathrm{LAE}$ & $5.69 \pm 0.02$ & 3.13 & $6.53 \pm 0.02$ & 2.20 & $6.22 \pm 0.00$ & 2.37 \\
\hline
\end{tabular}

Table 3. Antimicrobial effectiveness against L. monocytogenes, E. coli, and S. enterica. EVOH44 films with $0.25 \%, 1 \%, 5 \%$, and 10\% LAE. Expressed as logarithm of colony forming units (Log(CFU) and log reduction value (LRV).

L. monocytogenes

E. coli

S. enterica

\begin{tabular}{|c|c|c|c|c|c|c|}
\hline & $\log (\mathrm{CFU})$ & LRV & $\log (\mathrm{CFU})$ & LRV & $\log (\mathrm{CFU})$ & LRV \\
\hline Control & $8.43 \pm 0.47$ & & $8.56 \pm 0.28$ & & $8.87 \pm 0.14$ & \\
\hline 10\% LAE & \multicolumn{2}{|c|}{ Total inhibition } & \multicolumn{2}{|c|}{ Total inhibition } & \multicolumn{2}{|c|}{ Total inhibition } \\
\hline $5 \%$ LAE & \multicolumn{2}{|c|}{ Total inhibition } & \multicolumn{2}{|c|}{ Total inhibition } & \multicolumn{2}{|c|}{ Total inhibition } \\
\hline 1\% LAE & $4.21 \pm 0.14$ & 4.22 & $5.53 \pm 0.62$ & 3.03 & $5.49 \pm 0.53$ & 3.38 \\
\hline $0.25 \% \mathrm{LAE}$ & $6.99 \pm 0.22$ & 1.44 & $6.16 \pm 0.48$ & 2.40 & $6.41 \pm 0.24$ & 2.46 \\
\hline
\end{tabular}

incorporated in the film had exceeded the $\mathrm{MBC}$ value in all cases.

\subsection{Antimicrobial activity of LAE films over time.}

The antimicrobial activity of LAE films over time against L. monocytogenes, E. coli, and $S$. enterica was determined by the liquid medium method described in the experimental section.

The antimicrobial activity of EVOH29 films with 5\% and 10\% LAE was so high that they effectively inhibited the growth of L. monocytogenes, E. coli, and S. enteri$\mathrm{ca}$, from the beginning of the experiment, after $5 \mathrm{~min}$ in contact with the liquid medium (TSB) (data not shown).

The inhibitory effect of EVOH44 with LAE is presented in Figures 1, 2, and 3. Figure
1 shows the antimicrobial results obtained with EVOH44 films against L. monocytogenes. After 5 min of exposure, a 4 log reduction (compared to the control) was observed for film samples containing 5\% and $10 \%$ of LAE. Growth inhibition progressed with exposure time, and a total inhibition effect was observed after 30 min with 10\% LAE and 90 min with 5\% LAE.

Figure 2 shows the antimicrobial activity of EVOH44 against E. coli. Compared to L. monocytogenes, few antimicrobial effects were observed at the shortest time tested. As can be seen, no inhibition of this Gram-negative microorganism was observed after the first 5 min of immersion of the films containing 5\% and 10\% LAE; a small reduction in growth of E. coli was observed with 10\% LAE. At this exposure time, the film had probably released an amount of LAE close to the minimum inhibitory concentration 


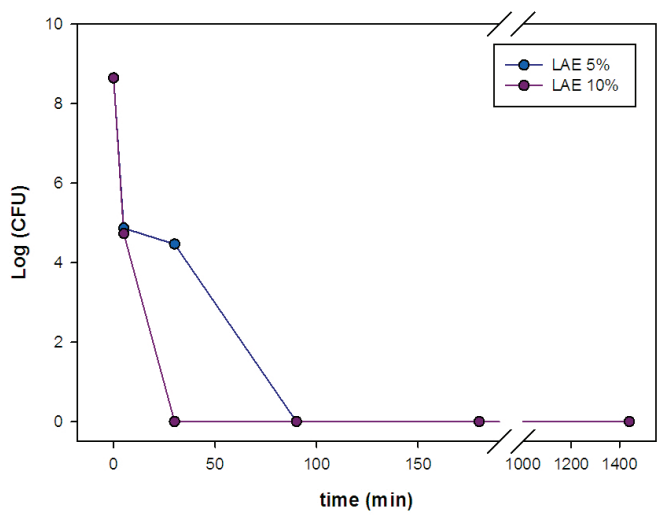

Figure 1. Antimicrobial activity of EVOH44 (5\% and 10\% LAE) films over time against L. monocytogenes.

(MIC), defined as the lowest concentration of active compound that yields inhibition of microorganism [29, 27]. Growth inhibition progressed with exposure time, and total inhibition of bacterial growth of E. coli was observed after 180 min with 10\% LAE and 300 min with 5\% LAE.

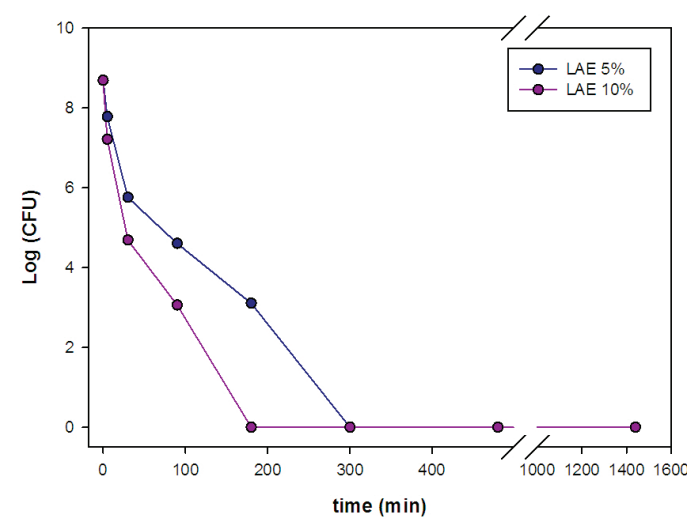

Figure 2. Antimicrobial activity of EVOH44 (5\% and 10\% LAE) films over time against E. coli.

Similar results were found against $S$. enterica, as shown in Figure 3. By increasing the immersion time used in the assay, or the LAE concentration in the film, higher inhibition against the microorganism was obtained. Total inhibition was achieved after 90 min with $10 \%$ LAE, or $180 \mathrm{~min}$ in the case of 5\% LAE.
Another study in liquid medium was carried out at $4{ }^{\circ} \mathrm{C}$ to test the effectiveness of the films at refrigeration temperatures and after prolonged exposure in order to represent storage. Antimicrobial activity of the EVOH films with LAE was tested against Gram-positive bacterium L. monocytogenes and Gram-negative bacteria E. coli and S. enterica.

Tables 4 and 5 show the results. Again, films with 5 and 10\% LAE produced total inhibition of growth against all the microorganisms tested. The viable counts decreased with $0.25 \%$ and $1 \%$ LAE.

As Table 4 shows, EVOH29 films containing 1\% LAE produced total inhibition against L. monocytogenes and reduced the growth of E. coli and S. enterica by about 3 log. Films containing 0.25\% LAE produced a reduction of 2.30 log against L. monocytogenes, $1.86 \log$ for E. coli, and 1.74 against $S$. enterica.

In the case of EVOH44 (Table 5), 1\% LAE samples produced a reduction of $3.34 \mathrm{log}$ against L. monocytogenes, and $2.66 \log$ and 2.38 log against E. coli and S. enterica with respect to the control sample. Lower inhibition was shown than with EVOH29, 1.67, 1.21, and 1.30 against L. monocytogenes, E. coli, and S. enterica, respectively, compared with the control samples.

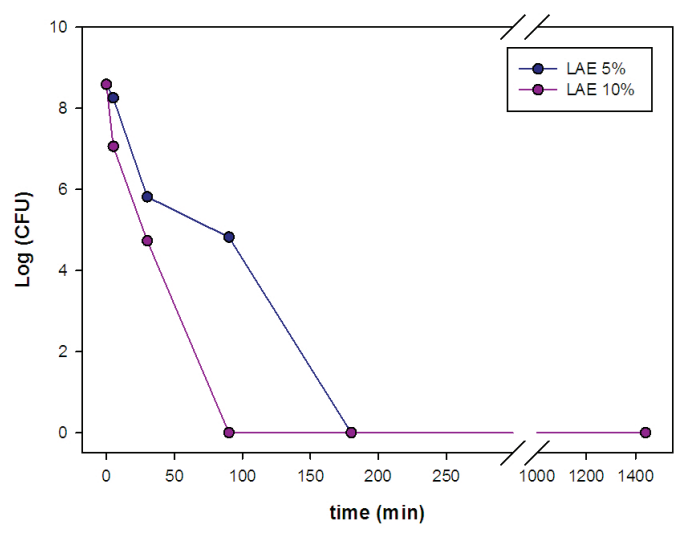

Figure 3. Antimicrobial activity of EVOH44 (5\% and 10\% LAE) films over time against S. enterica. 
The films with a higher concentration were able to release sufficient amounts of active compound to inhibit growth of all the microorganisms tested. Again, the EVOH29 film appeared to release the antimicrobial faster, resulting in a more efficient antimicrobial activity.

Table 4. Antimicrobial effect of EVOH29 films with $0.25 \%, 1 \%, 5 \%$ and $10 \%$ of LAE against E. coli, L. monocygones and $S$. enterica tested at $4{ }^{\circ} \mathrm{C}$.

L. monocytogenes

E. coli

S. enterica

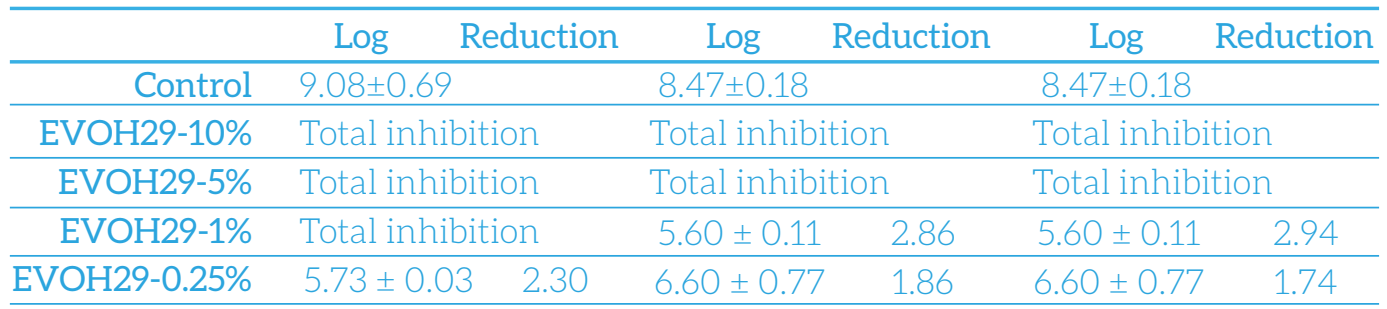

Table 5. Antimicrobial effect against L. monocytogenes, E. coli, and S. enterica. EVOH44 films with $0.25 \%, 1 \%, 5 \%$, and $10 \% \mathrm{LAE}$ tested at $4{ }^{\circ} \mathrm{C}$ expressed as logarithm of colony forming units (Log(CFU) and log reduction value (LRV).

L. monocytogenes

E. coli

S. enterica

\begin{tabular}{|c|c|c|c|c|c|c|}
\hline & Log (CFU) & LRV & $\log (\mathrm{CFU})$ & LRV & Log (CFU) & LRV \\
\hline Control & $9.01 \pm 0.14$ & & $9.02 \pm 0.02$ & & $8.21 \pm 0.27$ & \\
\hline $10 \% \mathrm{LAE}$ & \multicolumn{2}{|c|}{ Total inhibition } & \multicolumn{2}{|c|}{ Total inhibition } & \multicolumn{2}{|c|}{ Total inhibition } \\
\hline $5 \% \mathrm{LAE}$ & \multicolumn{2}{|c|}{ Total inhibition } & \multicolumn{2}{|c|}{ Total inhibition } & \multicolumn{2}{|c|}{ Total inhibition } \\
\hline $1 \% \mathrm{LAE}$ & $5.66 \pm 0.73$ & 3.34 & $6.43 \pm 0.10$ & 2.66 & $5.83 \pm 0.09$ & 2.38 \\
\hline $0.25 \% \mathrm{LAE}$ & $7.35 \pm 0.69$ & 1.67 & $7.88 \pm 0.01$ & 1.21 & $6.92 \pm 0.24$ & 1.30 \\
\hline
\end{tabular}

3.4 In vivo assay: Efficacy of LAE-films against $L$. monocytogenes and $S$. enterica in an infant formula

The infant formula was inoculated with the pathogenic microorganisms L. monocytogenes and S. enterica and placed in sterilized tubes with the films, capped and stored for 6 days at $4{ }^{\circ} \mathrm{C}$. The inhibitory effect of EVOH29 and EVOH44 films with LAE on the growth of L. monocytogenes and S. enterica is shown in Figures 4-7. Samples stored with the active film had a significant inhibitory effect against both bacteria tested.

Figures 4 also show the antimicrobial effectiveness of the active films against $L$. monocytogenes. After the $2^{\text {nd }}$ day of storage, a significant antimicrobial effect was shown by the films. At the end of the stora- ge period, all the active coatings produced significant inhibition, with a reduction of about 4 log in the case of 10\% LAE. Also, the greater the concentration of the agent and the longer the storage time, the higher the reduction.

Doyle and Beuchat observed that L. monocytogenes can grow at temperatures of 4 to $45^{\circ} \mathrm{C}$ [30], and refrigeration alone is not sufficient to prevent its growth in foods. The mean minimum growth temperature was found to be $1.1^{\circ} \mathrm{C}$, with a range of 0.5 to $3^{\circ} \mathrm{C}$ [21] and L. monocytogenes could survive pasteurization $[19,20]$. The characteristics of infant formula ( $\mathrm{pH}$ close to neutrality, large presence of nutrients) could favor an increase in viable counts of L. monocytogenes. 
As Figures 5 show, the presence of the antimicrobial agent against S. enterica, produced a reduction of ca. 1 log CFU with EVOH29 and 0.5 log CFU with EVOH44 after 2 days of storage. On the $6^{\text {th }}$ day of storage, the total bacteria counts for the infant formula packaged with the active samples showed a significant decrease in comparison with the control sample. EVOH29 5\% and 10\% LAE samples had reductions of $3.74 \mathrm{log}$ and $3.95 \mathrm{log}$, respectively, and EVOH44 5\% and 10\% LAE samples had reductions of $1 \mathrm{log}$ and 3.27 log respectively against S. enterica.
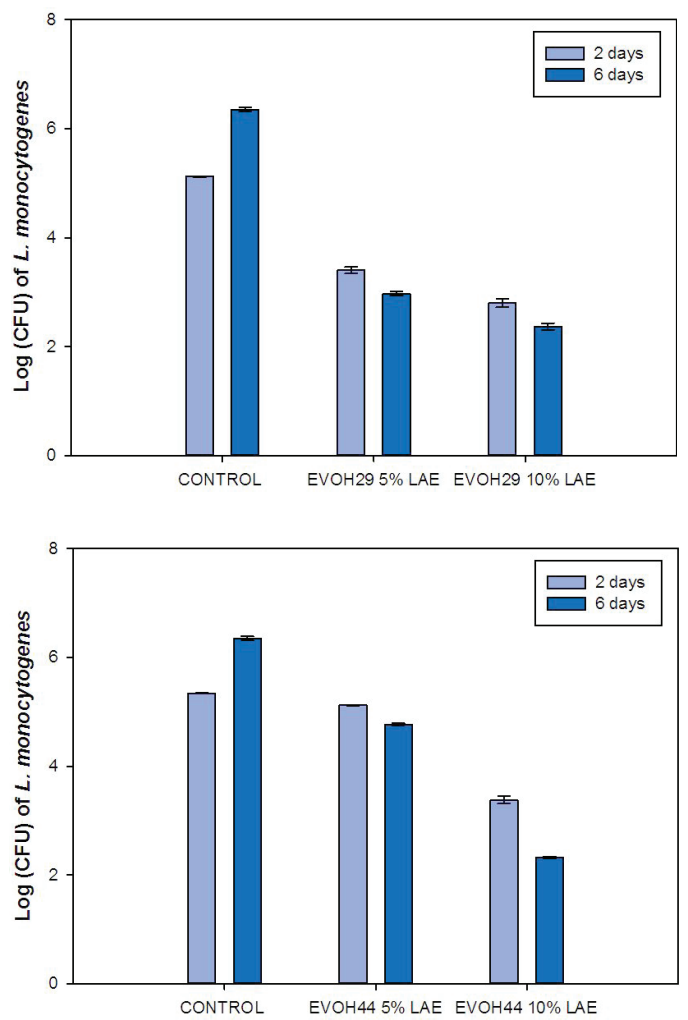

Figure 4. Growth reduction of L. monocytogenes inoculated in an infant formula at $2^{\text {nd }}$ and $6^{\text {th }}$ days of storage caused by EVOH29 films (control, 5\% LAE and 10\% LAE) and EVOH44 films (control, 5\% LAE and 10\% LAE).

Milk contamination can take place if excessive condensation and high humidity produce droplets that fall into open containers.
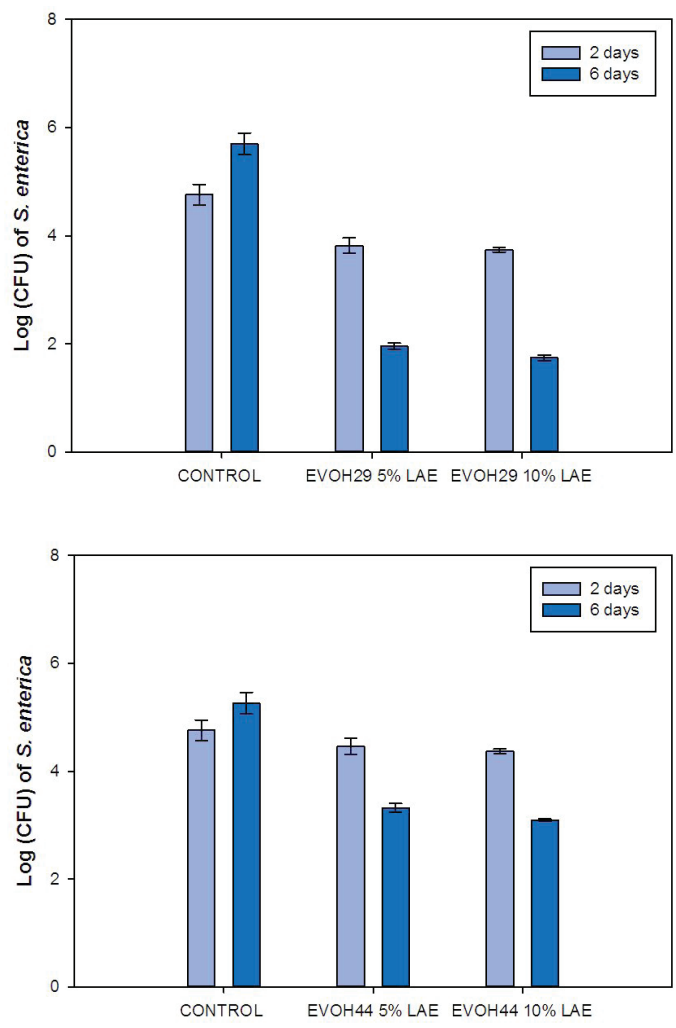

Figure 5. Growth reduction of S. enterica inoculated in an infant formula at $2^{\text {nd }}$ and $6^{\text {th }}$ days of storage caused by EVOH29 films (control, 5\% LAE and 10\% LAE) and EVOH44 films (control, 5\% LAE and 10\% LAE)

Salmonella may contaminate containers or milk contact surfaces after pasteurization because of environmental conditions in the plant. In the United States, between 1960 and 2000, 12 outbreaks were associated with pasteurized milk [10] Salmonella infection, or salmonellosis, causes fever, diarrhea, and cramping in addition to chills, headache, and other gastrointestinal symptoms. For children, salmonellosis can be fatal. The films used in the present study could be developed and applied as an inner coating of the packaging structure for infant formula, releasing the active agent and producing greater protection against contamination post pasteurization. 
The present study reveals that a much higher concentration of LAE is required in infant formula to produce total inhibition against L. monocytogenes and S. enterica, as observed in the in vitro tests with TSB. Other studies reported that a higher concentration of antimicrobial agents is generally required in real food compared with that in broth media [31, 32]. A reduction in antimicrobial activity of the agent owing to the nature of the food matrix has been documented [32, 33]. Thus, higher concentrations of agent are generally required when added to food [34].

Therefore, the use of antimicrobial packaging such as bottles/jar coatings can offer advantages, compared with the direct addition of preservatives to liquid foods, since only low levels of preservative come into contact with the food. These results values are indicative that incorporation of the agent in the EVOH coating in a multilayer structure could be an excellent active packaging for infant formula. The dairy industry is also developing minimal processing techniques [35] that can be used to prolong shelf life and improve sensorial characteristics of fluid milk. Therefore, it would be desirable to have an additional hurdle to improve the safety of liquid food products. Antimicrobial active coatings represent an innovative concept in food packaging, developed to answer the consumer's demand for better microbiological safety.

\section{Acknowledgments}

The authors acknowledge the financial support of the Spanish Ministry of Science and Innovation, project AGL2009-08776, and V. M.-G.'s fellowship. 


\section{REFERENCES}

[1] P. Suppakul, J. Miltz, K. Sonneveld, S.W. Bigger, Active packaging technologies with an emphasis on antimicrobial packaging and its applications, Journal of Food Science, 68 (2003) 408-420.

[2] Y. Zhang, K. Yam, M. Chikindas, Effective control of Listeria monocytogenes by combination of nisin formulated and slowly released into a broth system, International Journal of Food Microbiology, (2004) 15-22.

[3] P. Appendini, J.H. Hotchkiss, Review of antimicrobial food packaging, Innovative Food Science and Emerging Technologies, 3 (2002) 113-126.

[4] S.A. Ruckman, X. Rocabayera, J.F. Borzelleca, C.B. Sandusky, Toxicological and metabolic investigations of the safety of $\mathrm{N}$-alpha-lauroyll-arginine ethyl ester monohydrochloride (LAE), Food and Chemical Toxicology, 42 (2004) 245259.

[5] J.J. García Domínguez, Infante, M.R., Erra, P. and Julia, M.R., N alpha-acil-L-alkylaminoguanidinic acids and their salts surfactants with antimicrobial action. Spanish patent, 1983.

[6] J.B. Urgell Beltran, J. Seguer Bonaventura, Use of cationic preservative in food products, Lamirsa SA, 2003.

[7] E. Rodriguez, Cellular effects of monohydrochloride of L-arginine, Nalpha-lauroyl ethylester (LAE) exposure on Salmonella Typhimurium and Staphylococcus aureus, Journal of Applied Microbiology, 96 (2004) 903-912.

[8] G. Bakal, A. Diaz, The lowdown on lauric arginate, Food Quality, (2005) 60-61.

[9] J.B. Luchansky, J.E. Call, B. Hristova, L. Rumery, L. Yoder, A. Oser, Viability of Listeria monocytogenes on commercially-prepared hams surface treated with acidic calcium sulfate and lauric arginate and stored at 4degreesC, Meat Science, 71 (2005) 92-99.
[10] E.M. Martin, C.L. Griffis, K.L.S. Vaughn, C.A. O'Bryan, E.C. Friedly, J.A. Marcy, S.C. Ricke, P.G. Crandall, R.Y. Lary, Jr., Control of Listeria monocytogenes by lauric arginate on frankfurters formulated with or without lactate/diacetate, Journal of Food Science, 74 (2009) M237-M241.

[11] P.J. Taormina, W.J. Dorsa, Inactivation of Listeria monocytogenes on hams shortly after vacuum packaging by spray application of lauric arginate, Journal of Food Protection, 72 (2009) 2517-2523.

[12] K.A. Soni, R. Nannapaneni, M.W. Schilling, V. Jackson, Bactericidal activity of lauric arginate in milk and Queso Fresco cheese against Listeria monocytogenes cold growth, Journal of Dairy Science, 93 (2010) 4518-4525.

[13] M. Bonnaud, J. Weiss, D.J. McClements, Interaction of a food-grade cationic surfactant (lauric arginate) with food-grade biopolymers (pectin, carrageenan, xanthan, alginate, dextran, and chitosan), Journal of Agricultural and Food Chemistry, 58 (2010) 9770-9777.

[14] S. Aucejo, R. Catala, R. Gavara, Interactions between water and EVOH food packaging films, Food Science and Technology International/ Ciencia y Tecnologia de Alimentos Internacional, 6 (2000) 159-164.

[15] C. Lopez-de-Dicastillo, R. Catala, R. Gavara, P. Hernandez-Munoz, Food applications of active packaging EVOH films containing cyclodextrins for the preferential scavenging of undesirable compounds, Journal of Food Engineering, 104 (2011) 380-386.

[16] C. Lopez-de-Dicastillo, M. Gallur, R. Catala, R. Gavara, P. Hernandez-Munoz, Immobilization of beta-cyclodextrin in ethylene-vinyl alcohol copolymer for active food packaging applications, Journal of Membrane Science, 353 (2010) 184-191.

[17] C. Lopez-de-Dicastillo, J.M. Alonso, R. Catala, R. Gavara, P. Hernandez-Munoz, Improving the Antioxidant Protection of Packaged Food by Incorporating Natural Flavonoids into EthyleneVinyl Alcohol Copolymer (EVOH) Films, Journal of Agricultural and Food Chemistry, 58 (2010) 10958-10964. 
[18] R. Catala, R. Gavara, Developments in active food packaging, Arbor-Ciencia Pensamiento Y Cultura, 168 (2001) 109-127.

[19] D.W. Fleming, S.L. Cochi, K.L. MacDonald, J. Brondum, P.S. Hayes, B.D. Plikaytis, M.B. Holmes, A. Audurier, C.V. Broome, A.L. Reingold, Pasteurized milk as a vehicle of infection in an outbreak of listeriosis, New England Journal of Medicine, 312 (1985) 404-407.

[20] J. Lovett, D.W. Francis, J.M. Hunt, Listeria monocytogenes in raw milk: detection, incidence, and pathogenicity, Journal of Food Protection, 50 (1987) 188-192.

[21] J.R. Junttila, S.I. Niemela, J. Hirn, Minimum growth temperatures of Listeria monocytogenes and non-haemolytic listeria, Journal of Applied Bacteriology, 65 (1988) 321-327.

[22] M100-S18, Performance standards for antimicrobial susceptibility testing: Eighteenth informational supplement, in: Performance standards for antimicrobial susceptibility testing: Eighteenth informational supplement, Clinical and Laboratory Standards Institute. Wayne, PA. 2008, pp. 28:21.

[23] A. Smith-Palmer, J. Stewart, L. Fyfe, Antimicrobial properties of plant essential oils and essences against five important food-borne pathogens, Letters in Applied Microbiology, 26 (1998) 118-122.

[24] A.L. Brandt, A. Castillo, K.B. Harris, J.T. Keeton, M.D. Hardin, T.M. Taylor, Inhibition of Listeria monocytogenes by food antimicrobials applied singly and in combination, Journal of Food Science, 75 (2010) M557-M563.

[25] M. Vaara, Agents that increase the permeability of the outer membrane. Microbiological Reviews, (1992) 395-411.

[26] N. Canillac, A. Mourey, Antibacterial activity of the essential oil of Picea excelsa on Listeria, Staphylococcus aureus and coliform bacteria, Food Microbiology, 18 (2001) 261-268.

[27] P.J. Delaquis, K. Stanich, B. Girard, G. Mazza, Antimicrobial activity of individual and mixed fractions of dill, cilantro, coriander and eucalyptus essential oils, International Journal of Food Microbiology, 74 (2002) 101-109.
[28] S. Harpaz, L. Glatman, V. Drabkin, A. Gelman, Effects of herbal essential oils used to extend the shelf life of freshwater-reared Asian sea bass fish (Lates calcarifer), Journal of Food Protection, 66 (2003) 410-417.

[29] K.A. Hammer, C.F. Carson, T.V. Riley, Antimicrobial activity of essential oils and other plant extracts, Journal of Applied Microbiology, 86 (1999) 985-990.

[30] M.P. Doyle, L.R. Beuchat, Food microbiology: fundamentals and frontiers. ASM Press. Washington, D.C, 2007.

[31] V. Muriel-Galet, J.R. Cerisuelo, G. LopezCarballo, S. Aucejo, R. Gavara, P. HernandezMunoz, Evaluation of EVOH-coated PP films with oregano essential oil and citral to improve the shelf-life of packaged salad, Food Control, 30 (2013) 137-143.

[32] S. Burt, Essential oils: their antibacterial properties and potential appliations in foods - a review, International Journal of Food Microbiology, 94 (2004) 223-253.

[33] N. Belletti, R. Lanciotti, F. Patrignani, F. Gardini, Antimicrobial efficacy of citron essential oil on spoilage and pathogenic microorganisms in fruit-based salads, Journal of Food Science, 73 (2008) M331-M338.

[34] J. Gutierrez, C. Barry-Ryan, P. Bourke, The antimicrobial efficacy of plant essential oil combinations and interactions with food ingredients, International Journal of Food Microbiology, 124 (2008) 91-97.

[35] H.D. Goff, M.W. Griffiths, Major advances in fresh milk and milk products: fluid milk products and frozen desserts, Journal of Dairy Science, 89 (2006) 1163-1173. 


\section{CHARACTERIZATION OF ETHYLENE-VINYL ALCOHOL COPOLYMER CONTAINING LAURIL ARGINATE (LAE) AS MATERIAL FOR ACTIVE ANTIMICROBIAL FOOD PACKAGING}

Virginia Muriel-Galet', Gracia López-Carballo’', Rafael Gavara* and Pilar Hernández-Muñoz

Food Packaging and Shelf Life 2014, I, 10-18 


\section{ABSTRACT}

The aim of this work was to characterize, as packaging materials, antimicrobial films based on two different ethylene vinyl alcohol copolymers (EVOH29 and EVOH44) containing 5 and 10\% lauril arginate (LAE). The characterization included optical, surface, thermal and barrier properties of the developed films, as well as the release of the agent into aqueous media. The results show that the addition of LAE did not produce relevant changes in optical, but reduced the films' barrier properties to oxygen and water vapor, especially at high humidity conditions, and improved the wettability of the surface as demonstrated by the significant decrease in contact angle, both effects a consequence of the surfactant properties of the compound. The thermal properties confirmed that the distribution of LAE in the matrix was homogeneous, that the agent induced an antiplasticization effect and reduced the quality and percentage of the crystalline region, and that casting (or coating) is a suitable processing technology to reduce compound degradation. Finally, the release of LAE from EVOH films to water was characterized at 4 ${ }^{\circ} \mathrm{C}$ and $23^{\circ} \mathrm{C}$. This study showed that the agent was fully released into the food simulant from all films, although kinetically LAE diffusion was faster in EVOH29 and at higher temperature. All these results show that the developed films present excellent functional properties and are able to release the antimicrobial agents suitably, making them promising materials for active food packaging applications.

Keywords: EVOH, LAE, antimicrobial packaging, release. 


\section{INTRODUCTION}

Active antimicrobial packaging has received special attention in the last years since they are one of the most promising packaging alternatives in the use of less aggressive emerging food technologies. Antimicrobial packaging extends the shelf life of sensitive product by inhibiting or retarding the proliferation of microorganisms in food [1]. To avoid the risk of consumer manipulation of the active compounds, the addition of the agent within the packaging walls, that is, into the polymeric matrix that constitutes the packaging wall or onto the inner surface are the preferred incorporation methods. Diverse polymers have been studied as possible matrices for the incorporation of antimicrobial agents including biopolymers and synthetic polymers.

In a previous work [2], two different ethylene-vinyl alcohol copolymers (EVOH29 and EVOH44) were used as matrices to incorporate the antimicrobial agent Lauril arginate (LAE) and the results showed that the films presented excellent antimicrobial activity.

EVOH copolymers are common packaging materials classified as biodegradable and biocompatible [3] that present excellent oxygen barrier properties and a highly hydrophilic nature [4]. This latter property is highly inconvenient in applications where high barrier to oxygen is a requirement since water gain results in polymer plasticization and subsequently severe permeance increment. Recently, EVOH materials have been used as matrices for the development of active packaging systems. In these applications, water plasticization is beneficial because when the polymer is exposed to a humid environment (that is, the food packaging step) plasticization accelerates agent release, producing the ex- pected useful effect on the food $[2,5,6]$.

Lauril arginate, LAE, (95\% of ethyl-Ndodecanoyl-L-arginate hydrochloride) is a cationic surfactant, a derivative of lauric acid, L-arginine, and ethanol [7]. This compound is considered one of the most potent food antimicrobial agents with an extensive spectrum of antimicrobial activity [8], and it does not provide any taste or odor, in compliance with article 3 of the European Regulation on active food packaging materials [9]. In addition, it has been classified as GRAS (Generally Recognized as Safe) and food preservative by the Food and Drug Administration (FDA).

The purpose of this study was to characterize the functional properties of antimicrobial films based on two ethylene vinyl alcohol copolymers with different vinyl alcohol content (EVOH29 and EVOH44) containing 5 and 10\% of LAE so as to be considered suitable food packaging materials. It is known that the incorporation of agents into a polymeric matrix can modify unacceptably the engineering properties of the packaging materials [10]. The films were developed by a procedure that resembles film coating, which is the method considered for its application in packaging design. In such designs, mainly the substrate material is responsible for mechanical strength (reason why mechanical characterization of the active EVOH films were not included in this study), although the coating can modify many other relevant properties of the final structure. Accordingly, this characterization included optical, surface, thermal and barrier properties of the developed films, relevant to being used as conventional packaging materials and full evaluation of the agent release process into aqueous media, relevant to the design of efficient active packages. 


\section{MATERIALS AND METHODS}

\subsection{Materials}

Ethylene vinyl alcohol copolymers with 29\% ethylene molar content (EVOH29) and with 44\% ethylene molar content (EVOH44) were kindly provided by The Nippon Synthetic Chemical Company (Osaka, Japan). 1-propanol was purchased from Sigma (Madrid, Spain). The antimicrobial Lauril arginate $\left(\mathrm{C}_{20} \mathrm{H}_{41} \mathrm{~N}_{4} \mathrm{O}_{3} \mathrm{Cl}\right)$ was provided by Vedeqsa Grupo LAMIRSA (Terrassa, Barcelona, Spain). Water was obtained from a Milli-Q Plus purification system (Millipore, Molsheim, France).

\subsection{Film Preparation}

EVOH films were prepared as described elsewhere [2]. Briefly, the film forming solution was prepared by dissolving the copolymers in a mixture of 1-propanol and water, 1/1 (v/v) for EVOH29 and 2/1 (v/v) for $\mathrm{EVOH} 44$. The solutions were stirred using a magnetic stirrer hotplate at $50^{\circ} \mathrm{C}$. After solution, a concentration of 5 and 10\% LAE was added and stirred again for about $15 \mathrm{~min}$. Control films were obtained without LAE. EVOH solutions were extended over a clean glass plate using a $200 \mu \mathrm{m}$ deep thread spreading bar (Lin-Lab Rioja, Logroño, Spain). The films were dried in a tunnel equipped with a $2500 \mathrm{~W}$ heat source for $10 \mathrm{~min}$. The thickness of these films was determined with a Mitutoyo micrometer (Osaka, Japan) in each film before analysis.

\subsection{Optical properties}

A Konica Minolta CM-3500d spectrophotometer (Konica Minolta Sensing, Inc., Osaka, Japan) set to D65 illuminant $/ 10^{\circ}$ observer was used to determine the film color. The samples were measured against the surface of a standard white plate. The instrument's software SpectraMagic NX was employed to acquire the color data and to display them in the CIELAB color space. The parameters $L^{*}$ [black (0) to white (100)], $a^{*}$ [green $(-)$ to red $(+)$ ] and $b^{*}$ [blue $(-)$ to yellow $(+)$ ] were obtained and the polar coordinates, the chroma $C^{*}$ and the hue angle $h^{\circ}$ calculated. Eight measurements were taken of each sample, and three samples of each film were measured.

Film transparency was measured by using a Jasco V-360 spectrofotometer (Madrid, Spain) and monitoring the transmittance at $600 \mathrm{~nm}$ of $4.5 \times 1.2 \mathrm{~cm}$ samples. Three films were analyzed per sample.

Gloss was determined according to the ISO 2470 standard. Measurement of diffuse blue reflectance factor at $457 \mathrm{~nm}$ and with an angle of $10^{\circ}$ was carried out in a Konica Minolta, CM-2600d spectrophotometer (AquaTeknica, Spain). Five films were analyzed per sample.

\subsection{Contact angle}

The contact angles of control and active films were measured with an OCA 15 EC (DataPhysics Instruments, Germany) to determine the effect of the LAE incorporated into the surface wettability. A 2- $\mu \mathrm{L}$ drop of distilled water was placed on the film surface. The evolution of the droplet shape was recorded and the angle was determined after 60 s; SCA20 image analysis software was used to determine the contact angle evolution. All measurements were conducted under standard atmospheric conditions at $23 \pm 1{ }^{\circ} \mathrm{C}$ and a minimum of three measurements, taken at different positions on the film, and three samples of each film were measured. 


\subsection{Thermal characterization}

The glass transition (Tg) and melting point (Tm) temperatures and the melting enthalpy $(\triangle \mathrm{Hm})$ of the samples were determined with a DSC Model Q2000 from TA Instruments (New Castle, DE, EEUU). Film samples (ca. $7 \mathrm{mg}$ ) previously dried in a desiccator containing $\mathrm{P}_{2} \mathrm{O}_{5}$ were accurately weighted in a Tzero aluminum pan hermetically sealed with a Tzero lid from TA instruments. The heating profile was as follows: fast cooling to $-60{ }^{\circ} \mathrm{C}$ and isotherm period of $5 \mathrm{~min}$, first heating from $-60{ }^{\circ} \mathrm{C}$ to $250^{\circ} \mathrm{C}$ with a $10{ }^{\circ} \mathrm{C} / \mathrm{min}$ heating and 5 min isotherm period, first cooling from 250 ${ }^{\circ} \mathrm{C}$ to $-60{ }^{\circ} \mathrm{C}$ with a $10{ }^{\circ} \mathrm{C} / \mathrm{min}$ cooling and $5 \mathrm{~min}$ isotherm period and second heating from $-60{ }^{\circ} \mathrm{C}$ to $250{ }^{\circ} \mathrm{C}$ with a $10{ }^{\circ} \mathrm{C} / \mathrm{min}$ heating and $5 \mathrm{~min}$ isotherm period. $\mathrm{Tg}, \mathrm{Tm}$ and $\Delta H m$ were estimated with the instrument Universal Analysis software in the three cycles.

\subsection{Barrier Properties}

\subsubsection{Water Vapor Permeability (WVP)}

WVP tests were carried out with a humidity gradient of 50 and $90 \% \mathrm{RH}$ and $23{ }^{\circ} \mathrm{C}$ using permeability cups (Elcometer, Manchester, England) in accordance with ISO 2528 (ISO 2528:1995, 1995). The aluminum cups were filled with $7 \mathrm{~g}$ of silica gel and sealed with vacuum silicon grease (Sigma, Barcelona Spain) and the film to be tested. The film was fixed in place with a flat Viton ring, an aluminum ring and three press-screws. To assure the necessary relative humidity gradient, the cups were then stored in desiccators containing saturated salt solution: magnesium nitrate $\mathrm{Mg}\left(\mathrm{NO}_{3}\right)_{2} .6 \mathrm{H}_{2} \mathrm{O}$ and barium chloride $\mathrm{BaCl}_{2}$ for 50 and $90 \% \mathrm{RH}$, respectively. The cups were weighed daily, and the water vapor permeability values were obtained from the slope of the plot of the cell weight vs. time $(\mathrm{dm} / \mathrm{dt})$ :

$$
W V P=\frac{d m}{d t} \cdot \frac{l}{A \cdot \Delta p}
$$

where $\Delta \mathrm{p}$ is the water pressure gradient, $\mathrm{A}$ the film surface area and $\ell$ the film sample thickness.

\subsubsection{Oxygen Permeability (OP)}

The oxygen permeation rates of the materials were determined at 50 and $90 \% \mathrm{RH}$ and $23{ }^{\circ} \mathrm{C}$ using an OXTRAN Model 2/21 ML Mocon (Lippke, Neuwied, Germany). The film samples were previously conditioned at the RH of the experiment in the desiccators described above. After conditioning the samples in the OXTRAN cells, the permeability values were determined from the steady state transmission rate values.

\subsection{Release studies}

A study of the release of LAE from the EVOH films was carried out by determining the agent concentration in Milli-Q water, which was used as aqueous food simulant. Release studies were conducted at 23 and $4{ }^{\circ} \mathrm{C}$. Double-side, total immersion migration tests were performed as follows: $3 \mathrm{~cm}^{2}$ of each film sample and $5 \mathrm{~mL}$ of the simulant (area-to-volume ratio $=6$ $\mathrm{dm}^{2} / \mathrm{L}$ ) were placed in tubes UNE-EN 11863 (2002). Released LAE was determined at diverse immersion times by High Performance Liquid Chromatography (HPLC) with a UV-Vis absorbance detector. An Agilent 1200 series HPLC system equipped with a C18 reversed-phase column (150 x $3.9 \mathrm{~mm}, 5 \mu \mathrm{m}$ ) and a DAD Model G1513A was used and the Absorbance data were recorded at $205 \mathrm{~nm}$. The mobile phase was acetonitrile:water 50:50 (v/v) containing $0.1 \%$ trifluoroacetic acid, the flow rate 1 $\mathrm{ml} / \mathrm{min}$, the temperature $23^{\circ} \mathrm{C}$ and the injection volume $20 \mu \mathrm{L}$. A previous calibration was performed by injecting known amounts of the compound. 


\subsection{Statistical analysis}

One-way analyses of variance were carried out using the SPSS ${ }^{1} 19$ computer program (SPSS Inc., Chicago, IL, USA). Differences in pairs of mean values were evaluated by the Tukey-b test for a confidence interval of $95 \%$. Data are represented as mean \pm standard deviation.

\section{RESULTS AND DISCUSSION}

EVOH films without LAE (EVOH29 and EVOH44) and with 5 and 10\% of LAE (EVOH29-5\% and EVOH44-5\%) and (EVOH29-10\% and EVOH44-10\%) were successfully manufactured by the casting procedure. Films were transparent and without discontinuities, with a thickness of $15 \pm 1 \mu \mathrm{m}$. Films were stored in desiccators with silica gel until tested, to maintain stability [2].

\subsection{Optical properties}

The $L^{*}, a^{*}, b^{*}, C^{*}$ and $h^{\circ}$ parameters of EVOH29 and 44 without LAE and with 5 and 10\% of LAE were analysed and the results are shown in Table 1. EVOH29 and 44 films were transparent, as indicated by their $L^{*}$ values well above 90 . The low values of $a^{*}$ and $b^{*}$, close to zero and very similar to the control films, indicated that the films were practically colorless. The film chromaticity $\left(C^{*}\right)$ and saturation values $\left(h^{\circ}\right)$ increased with the concentration of LAE incorporated and developed a similar green-blue color. Nevertheless, the addition of the antimicrobial agent does not reduce the luminosity and does not affect the color of the films to the naked eye. Transparency and gloss are also relevant properties in packaging applications since they are related to the way consumer perceives the packaged product. Table 1 includes the average values of these two properties and as can be seen the addition of the agent does not significantly affect either of these parameters, with all films showing high transparency and gloss.

Table 1. Color parameters, transparency and gloss of EVOH29 and EVOH44, without LAE and with 5 and $10 \%$

\begin{tabular}{|c|c|c|c|c|c|c|c|}
\hline & $L^{*}$ & $a^{*}$ & $b^{*}$ & $C^{*}$ & $h^{\circ}$ & $\% \mathrm{~T}$ & Gloss \\
\hline EVOH29 & $95.25 \pm 0.33^{a}$ & $-0.17 \pm 0.02^{a}$ & $-0.14 \pm 0.06^{a}$ & $0.23 \pm 0.04^{a}$ & $218.4 \pm 11.6^{a}$ & $85.48 \pm 1.01^{a}$ & $98.53 \pm 0.13^{a}$ \\
\hline EVOH $295 \%$ LAE & $94.57 \pm 0.27^{a}$ & $-0.19 \pm 0.01^{a}$ & $-0.20 \pm 0.02^{a}$ & $0.28 \pm 0.02^{a}$ & $224.9 \pm 4.6^{a}$ & $85.93 \pm 0.60^{a}$ & $98.63 \pm 0.15^{a}$ \\
\hline EVOH $2910 \%$ LAE & $95.60 \pm 0.17^{a}$ & $-0.20 \pm 0.01^{a}$ & $-0.28 \pm 0.03^{b}$ & $0.33 \pm 0.02^{b}$ & $234.8 \pm 1.5^{b}$ & $83.19 \pm 1.66^{a}$ & $98.36 \pm 0.24^{a}$ \\
\hline EVOH44 & $94.62 \pm 0.19^{a}$ & $-0.19 \pm 0.01^{a}$ & $-0.34 \pm 0.03^{a}$ & $0.39 \pm 0.02^{a}$ & $241.6 \pm 2.2^{a}$ & $85.93 \pm 0.02^{a}$ & $97.78 \pm 0.40^{a}$ \\
\hline EVOH44 5\% LAE & $93.34 \pm 0.01^{a}$ & $-0.21 \pm 0.01^{a}$ & $-0.39 \pm 0.08^{a}$ & $0.44 \pm 0.07^{a}$ & $241.1 \pm 4.9^{a}$ & $87.65 \pm 2.28^{a}$ & $97.98 \pm 0.69^{a}$ \\
\hline EVOH44 10\% LAE & $95.33 \pm 0.11^{a}$ & $-0.23 \pm 0.01^{a}$ & $-0.51 \pm 0.03^{b}$ & $0.56 \pm 0.02^{b}$ & $245.3 \pm 2.1^{a}$ & $88.23 \pm 0.39^{a}$ & $98.15 \pm 0.29^{a}$ \\
\hline
\end{tabular}




\subsection{Contact angle}

The contact angle is defined as the angle between the surface of a liquid and the tangent line at the point of contact with the substrate. Contact angle measurements were used to characterize the surface properties of EVOH films containing LAE and the results are shown in Table 2 . As can be seen all values are well below $90^{\circ}$, values which are indicative of materials that are wetted by water, as expected from a family of films with hydrophilic character. It was also noted that the contact angles are lower for EVOH29 than EVOH44 films which is due to the increasing presence of $\mathrm{OH}$ substituents. Also, data showed that the contact angle decreases as the concentration of LAE increases. It is well-known that LAE is an amphiphilic compound [11] and may modify the surface hydrophobicity. Substances of this kind are commonly added to polyolefins to provide antifogging properties.

\subsection{Thermal characterization}

Thermal analyses of the films were carried out to study the influence of the addition of LAE on the thermal properties of the EVOH copolymers. As an example, Figure 1 shows the 3-cycle representative thermograms obtained for EVOH29 and EVOH29-

Table 2. Contact angle of EVOH29 and EVOH44, without LAE and with 5 and 10\%

SAMPLE

EVOH29

EVOH29 5\% LAE

EVOH29 10\% LAE

EVOH44

EVOH44 5\% LAE

EVOH44 10\% LAE

a, b, c indicate significant differences among the values of the contact angle (Turkey's adjusted analysis of variance $P<0.05$ )
10\%. As can be seen, the glass transition and the melting process are observable in the heating cycles, while the glass transition and the crystallization process are recognizable in the cooling cycle. Since the films were prepared by a casting process which could be considered similar to a coating process by a gravure or flexo technology, the most relevant information is obtained from the first heating cycle since it actually reflects the polymer morphology obtained after the drying step. Nevertheless, some relevant features can also be remarked by comparison between first and second cycle. As for the neat copolymers (see EVOH29 thermogram in figure 1), an endotherm was observed at a temperature of ca. $110{ }^{\circ} \mathrm{C}$ which is attributed to the evaporation of some water and alcohol trapped in the matrix that could not be removed during the drying storage. In dry conditions and below Tg, the EVOH copolymers are well-known barrier materials to molecular transport and as the film dries out through the surface, the barrier improvement practically impedes the release of solvent molecules present at deeper free volume positions within the matrix [12]. This small but relevant residual solvent content also produces some plasticization which is reflected by a glass transition temperature during the first cycle of ca. 43 ${ }^{\circ} \mathrm{C}$, near $13^{\circ} \mathrm{C}$ below that observed during the second heating process. At temperatures of ca. $180{ }^{\circ} \mathrm{C}$, the crystalline portion of EVOH29 melts (150 ${ }^{\circ} \mathrm{C}$ for EVOH44), values which are close to those measured in extruded EVOH copolymers [13]. In this endothermic process, there are also differences between first and second heating cycles. The cast film (first cycle) showed a wider and cooler melting process when compared to the melted polymer (second cycle), probably due to a more irregular and more fragmented crystalline structure. Similar comments are valid for the thermal behavior of EVOH44 films. 


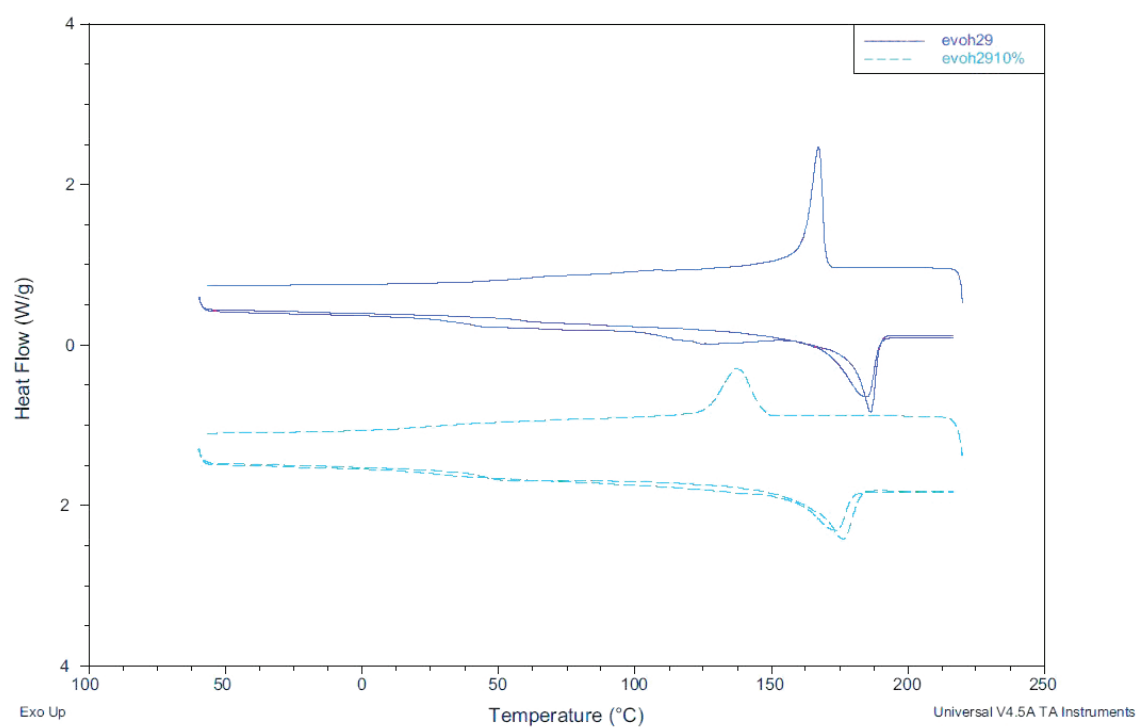

Figure 1. DSC thermograms of EVOH29 without LAE and with 5 and 10\%

With the incorporation of LAE, the first heating cycle showed the three features already explained for EVOH29 but with some differences. First of all, the glass transition was observed at a slightly higher temperature, the solvent evaporation was not so visible and the melting processes took place at significant lower temperatures (also obvious in the crystallization feature observed during the cooling process). When first and second heating cycles were compared, another very relevant issue should be noticed. The glass transition occurred at cooler temperatures during the second cycle, between 10 and $20^{\circ} \mathrm{C}$ below. All these effects were attributed to the possible thermal degradation of LAE or to a reaction between agent and polymer. This hypothesis would prevent any attempt of manufacturing EVOH containing LAE by extrusion technologies. It is also relevant to mention that there is no sign of LAE melting process which takes place as a sharp feature at $50{ }^{\circ} \mathrm{C}$ (thermogram not shown), which is indicative of a homogeneous distribution of the antimicrobial compound in the polymer matrix.

Table 3 shows the most relevant thermal information of the developed materials.
As can be seen, the glass transition temperature increases significantly with the concentration of LAE in cast films manufactured from both copolymers. This antiplasticization effect has been observed when the presence of a compound within a polymer matrix increases interchain cohesion [14]. After the melting and cooling processes, the glass transition largely decreases with LAE concentration as a result of degradation processes. With respect to the crystallinity of the polymer, there is some uncertainty in the results from LAE degradation, agent-polymer reactions could be hidden within the melting feature. Nevertheless, and considering that the endotherm is only due to the melting process, the table shows that the addition of LAE results is a lesser and more deficient crystalline portion, effect which increases with LAE concentration. This effect should be expected since the presence of substances in the polymer bulk interfere with the normal crystal growth. Other features observed in the second and third cycle are not studied further since the scope of this work was to assess the potential application of LAE-EVOH films obtained by coating technologies where temperature above $80^{\circ} \mathrm{C}$ are rare. 
Table 3. Thermal properties obtained from DSC thermograms of EVOH29 and 44, without LAE and with 5 and 10\%. Glass transition temperature ( $\mathrm{Tg}$ ) obtained at the first and second heating processes, and melting point $(\mathrm{Tm})$ and enthalpy $(\triangle \mathrm{H} \mathrm{m})$ obtained at the first heating.

\begin{tabular}{|c|c|c|c|c|}
\hline & \multicolumn{2}{|c|}{$\operatorname{Tg}\left({ }^{\circ} \mathrm{C}\right)$} & $\operatorname{Tm}\left({ }^{\circ} \mathrm{C}\right)$ & $\Delta \mathrm{Hm}(\mathrm{J} / \mathrm{g})$ \\
\hline & First heating & Second heating & & \\
\hline EVOH29 & $43.2 \pm 1.0^{a}$ & $55.5 \pm 1.5^{c}$ & $184.6 \pm 0.6^{c}$ & $70.7 \pm 2.4^{b}$ \\
\hline EVOH $295 \%$ LAE & $45.1 \pm 0.3^{b}$ & $42.2 \pm 2.8^{b}$ & $178.9 \pm 1.8^{b}$ & $68.4 \pm 2.9^{b}$ \\
\hline EVOH29 $10 \%$ LAE & $46.3 \pm 0.6^{c}$ & $29.9 \pm 0.8^{a}$ & $174.6 \pm 1.5^{a}$ & $53.8 \pm 2.1^{a}$ \\
\hline EVOH44 & $46.5 \pm 0.3^{a}$ & $50.3 \pm 1.3^{c}$ & $174.5 \pm 1.5^{b}$ & $72.8 \pm 2.3^{b}$ \\
\hline EVOH44 $5 \%$ LAE & $47.0 \pm 0.7^{a}$ & $34.0 \pm 1.1^{b}$ & $156.4 \pm 1.8^{a}$ & $66.2 \pm 3.1^{a}$ \\
\hline$\overline{\text { EVOH44 } 10 \% \text { LAE }}$ & $48.8 \pm 0.5^{b}$ & $29.1 \pm 3.1^{a}$ & $155.5 \pm 1.9^{a}$ & $62.2 \pm 1.9^{a}$ \\
\hline
\end{tabular}

a, b, c indicate significant differences among the values of the same property obtained for samples with the same base-copolymer (Turkey's adjusted analysis of variance $P<0.05$ )

\subsection{Barrier Properties}

\subsubsection{Water vapor permeability (WVP)}

The water vapor permeability values for all samples were determined at $23{ }^{\circ} \mathrm{C}$ with 50 and $90 \% \mathrm{RH}$ gradients and the results are included in figure 2 . The most relevant feature is the increment in permeability values caused by the water gradient at which samples were exposed. As the humidity increases EVOH copolymers are known to gain increasing amounts of water which results in plasticization of the matrix and deterioration of barrier properties. This effect is significant in all tested samples independently of the content of LAE and of the ethylene content of the copolymer. In presence of humidity, sorbed water molecules interact by hydrogen bonding with the $-\mathrm{OH}$ groups of $\mathrm{EVOH}$, reducing the interchain interactions and increasing the flexibility and permeability to gases and vapors [13]. When EVOH copolymers are compared, the increment in permeability observed from tests with 50\% $\mathrm{RH}$ gradient to tests with 90\% RH is greater for EVOH29 than for EVOH44 based films. In fact, at 50\% RH gradient EVOH29 films were less permeable to water vapor than EVOH44, but the contrary applied when tests were carried out with a 90\% $\mathrm{RH}$ gradient. The higher percentage of alcohol containing segments in EVOH29, increases the interchain energy cohesion in the matrix improving the barrier to mass transport, but in parallel, increases the hydrophilic behaviour and the plasticization capacity of the copolymer when exposed to humid environments. This observed effect is in agreement with a number of studies in which water permeability considerably increased in humid conditions $[4,15,16]$.

Considering the presence of LAE in the polymer matrices, the incorporation of the agent to both EVOH copolymers produced similar effects on WVP at 50 and 90\%, the WVP values increased with the addition of LAE. As DSC analysis revealed, the presence of LAE largely reduced the crystallinity percentage of the EVOH matrix, and therefore, increased the amorphous regions were mass transport takes place. This effect is more relevant when the test is carried out at low RH. At high humidities, the 
plasticization caused by the sorbed water becomes more important than that caused by LAE, the effect of LAE concentration being less noticeable although significant (p>0.05) in all cases.

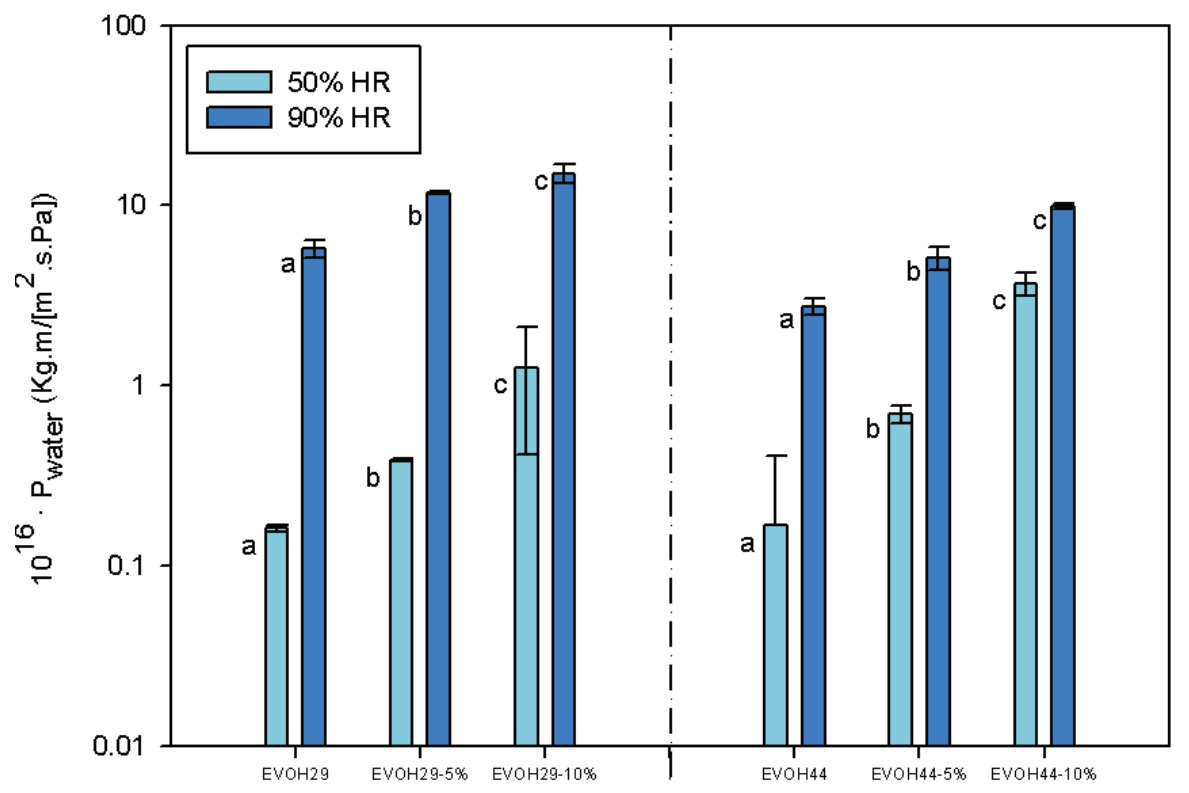

Figure 2. Water Vapor Permeability for EVOH29 and EVOH44, without LAE and with 5 and 10\%. Different letters (a, b, c) indicate significant differences among the values of WVP (Turkey's adjusted analysis of variance $P<0.05$ )

\subsubsection{Oxygen permeability (OP)}

Without doubt, the oxygen barrier properties of EVOH copolymers are the most appreciated characteristics of these packaging materials and are the main reason for their application in food packaging design. The hydrophilic character of these copolymers makes these barrier properties very sensitive to humidity, requiring water protection in application where oxygen barrier is a must. It has been reported that EVOH29 presents minimum values to oxygen permeability under conditions between 20$40 \% \mathrm{RH}$, increasing in 2 orders of magnitude when the humidity is $90 \%[13,17]$. In this study, the influence of LAE incorporation in the oxygen permeability of EVOH films and on the sensitivity of this property with humidity was determined. Figure 3 shows the oxygen permeability values at 50 and $90 \% \mathrm{RH}$ and $23^{\circ} \mathrm{C}$. As commen- ted in the WVP section, the permeability to oxygen also increased significantly with the environmental humidity, 100 fold for EVOH29 and 10 fold for EVOH44.

The incorporation of the antimicrobial agent increases the permeability of both EVOH copolymers by a factor of 2 to 5 , this increment being greater with the concentration of LAE. The reason for this increment is most probably the reduction of the crystallinity in the polymer caused by the presence of the LAE molecules. Nevertheless, at low humidity (50\% RH) this effect is less pronounced, probably due to the antiplasticization effect also observed in the thermal analysis, which may impose greater polymer chain movement restrictions and diffusivity constrictions. At higher humidity conditions, the water plasticization eliminates this effect and the presence of crystals are the only limitation to mass 


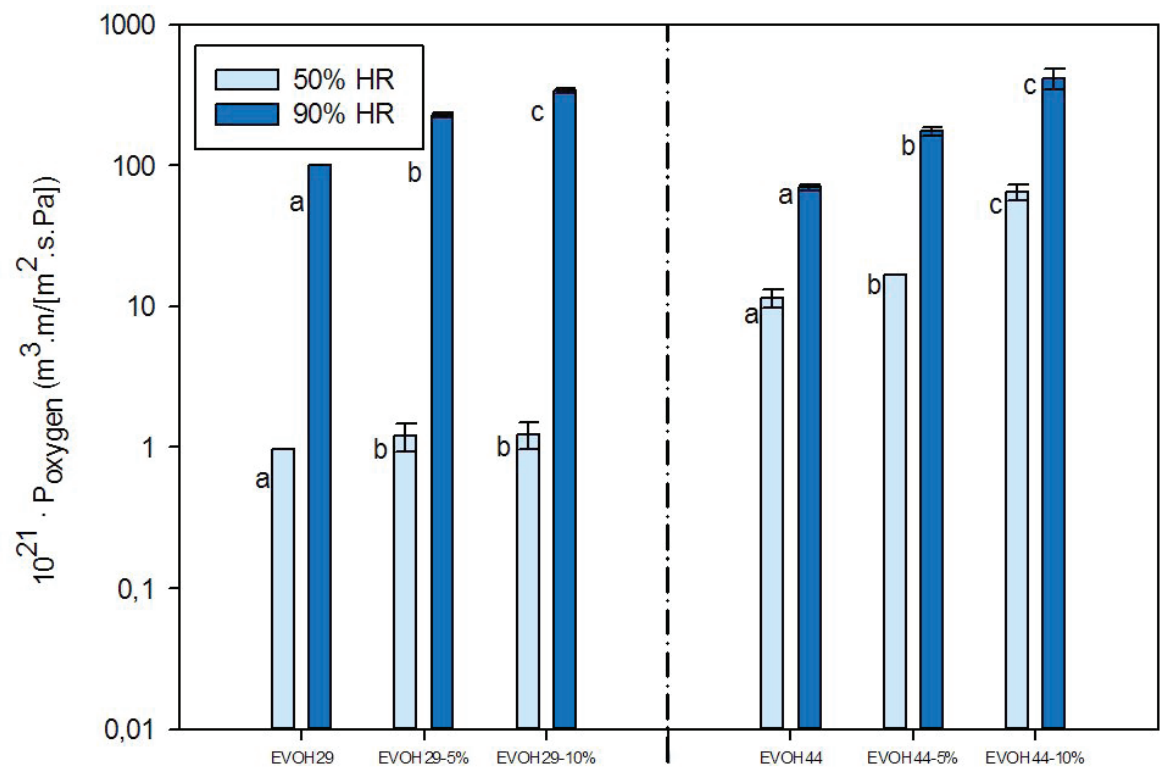

Figure 3. Oxygen permeability of EVOH29 and EVOH44, without LAE and with 5 and 10\%. Different letters (a, b, c) indicate significant differences among the values of OP (Turkey's adjusted analysis of variance $P<0.05$ )

transport, the addition of LAE resulting in higher OP values.

\subsection{Antimicrobial agent release}

The antimicrobial efficiency of the LAE incorporated materials is mainly based on an effective release of the compound into the food. Thus, a characterization of the agent release from the EVOH films into water (used as food simulant) was carried out at room $\left(23 \pm 1^{\circ} \mathrm{C}\right)$ and refrigeration $\left(4 \pm 1^{\circ} \mathrm{C}\right)$ temperatures. The extent of LAE release into the food simulant at equilibrium can be characterized by the partition coefficient $(K)$, defined as the ratio between the compound concentrations in the polymeric phase and in the food phase. Figure 4 and 5 shows the results of the release test of EVOH29 and 44 with 5 and 10\% at 23 ${ }^{\circ} \mathrm{C}$ and $4{ }^{\circ} \mathrm{C}$, respectively. As can be seen, the antimicrobial compound was desorbed in water continuously following a profile similar to an exponential function which tends to a maximum value. Although the release is not complete within the time of the experiment, the amount of LAE migrated to the food simulant approaches full extraction at $23{ }^{\circ} \mathrm{C}$ for both materials. Interestingly, when the amount release is expressed as a percentage with respect to nominal content (like in figures), the values observed for samples with 5\% and 10\% LAE are intermingled. This characteristic is indicative of the release advancing toward full migration, that is, $\mathrm{K}$ approaches zero. Otherwise, migration from samples with higher concentration would have advanced at a slower pace due to the approximation to equilibrium and the percentage of release would have been lower than for the sample with lower concentration.

Kinetically, the description of LAE diffusion through the polymer matrix is more complex because when the sample is immersed in the simulant, water is sorbed and diffuses through the matrix, plasticizing the polymer whilst the LAE is released and redistributed in the EVOH structure. In some studies focused on the mass transport of substances in hydrophilic polymers, 
the swelling (or even dissolution) of the polymer caused by water has been interpreted as a change in the position of the polymer/simulant interface as well as a change on the diffusion through the swollen part [18]. However, and despite the severe plasticization of EVOH exposed to water, the water uptake by EVOH is very low compared to PVOH, chitosan or other hydrocolloids and ranges between 9 and 12\% for all EVOH grades [19]. Thus, dimension changes on EVOH films caused by swelling can be neglected. Nevertheless, the plasticization of the polymer depends on the water concentration in any region of the polymer and therefore, the D of any substance will change with water presence until the water concentration is homogeneous and constant throughout the matrix. At this point, plasticization is homogeneous and D is constant for the released substance. Taking into account that the water molecule is very small compared with organic molecules of aromas, aminoacids or fatty acids, one can consider that the water intake oc- curs at such a fast pace that in practice, the film is equilibrated at the earliest stages of the release of the organic substance. This approach has previously been considered with pinene, ethyl butyrate, quercetin or catequin, and a successful description was obtained $[12,15,20]$. In the present work, the LAE molecule is really large and accordingly the diffusion coefficient will be much lower than those of the referred substances, making this assumption even more valid. Therefore, assuming that a) release occurs through both side surfaces of the film, b) LAE is distributed uniformly, c) the compound is fully released from the film, d) the diffusion coefficient of LAE in the polymer matrix is independent of temperature and position and e) the antimicrobial concentration in the food medium is homogeneous, the evolution with the time of LAE release from EVOH with respect to that at the end of the process $\left(\mathrm{m}(\mathrm{t}) / \mathrm{m}^{\mathrm{f}} \mathrm{s}\right)$ can be described by the following solution to Fick's laws:

$$
\frac{m(t)}{m^{f} s}=\frac{m(t)}{c p^{i} \cdot A \cdot l}=\left[1-\frac{8}{\pi^{2}} \sum_{n=0}^{\infty} \frac{1}{(2 n+1)^{2}} \exp \left(\frac{-D(2 n+1)^{2} \pi^{2} t}{\ell^{2}}\right)\right]
$$

being $\mathrm{Cp}^{\mathrm{i}}$ initial concentration of the antimicrobial agent, $\mathrm{A}$ and $\ell$ the area and the thickness of the EVOH and D the diffusion coefficients of LAE in the polymer.

Equation (1) has been used to describe the experimental release data plotted in figures 4 and 5. The continuous lines included in these figures are the theoretical curves obtained with the $\mathrm{D}$ values which provided the best fit, values which have been included in the figures' legends. As can be seen the description is acceptable considering the dispersion of the experimental data. This dispersion is assumed to be caused by heterogeneous distribution of the agent in the matrix. Since the sample surface of each experiment is small, difference in initial concentration in the sample could be responsible for this dispersion. Since the agent is not volatile and stable under processing conditions, the actual average concentration is in practice the nominal one as determined in an independent experiment with a $4 \mathrm{dm}^{2}$ sample exposed to water at 37 ${ }^{\circ} \mathrm{C}$ during $48 \mathrm{~h}$.

The first observation from these figures is that the release of the antimicrobial compound is faster and more effective at $23^{\circ} \mathrm{C}$ than at $4^{\circ} \mathrm{C}$ for both copolymers materials, an expected result since mass diffusion is a kinetic parameter that depends on temperature exponentially following the Arrhenius law. Also, the D values showed that the diffusivity of LAE in EVOH29 is faster than in EVOH44 at both temperatures, suggesting that EVOH29 releases the active 


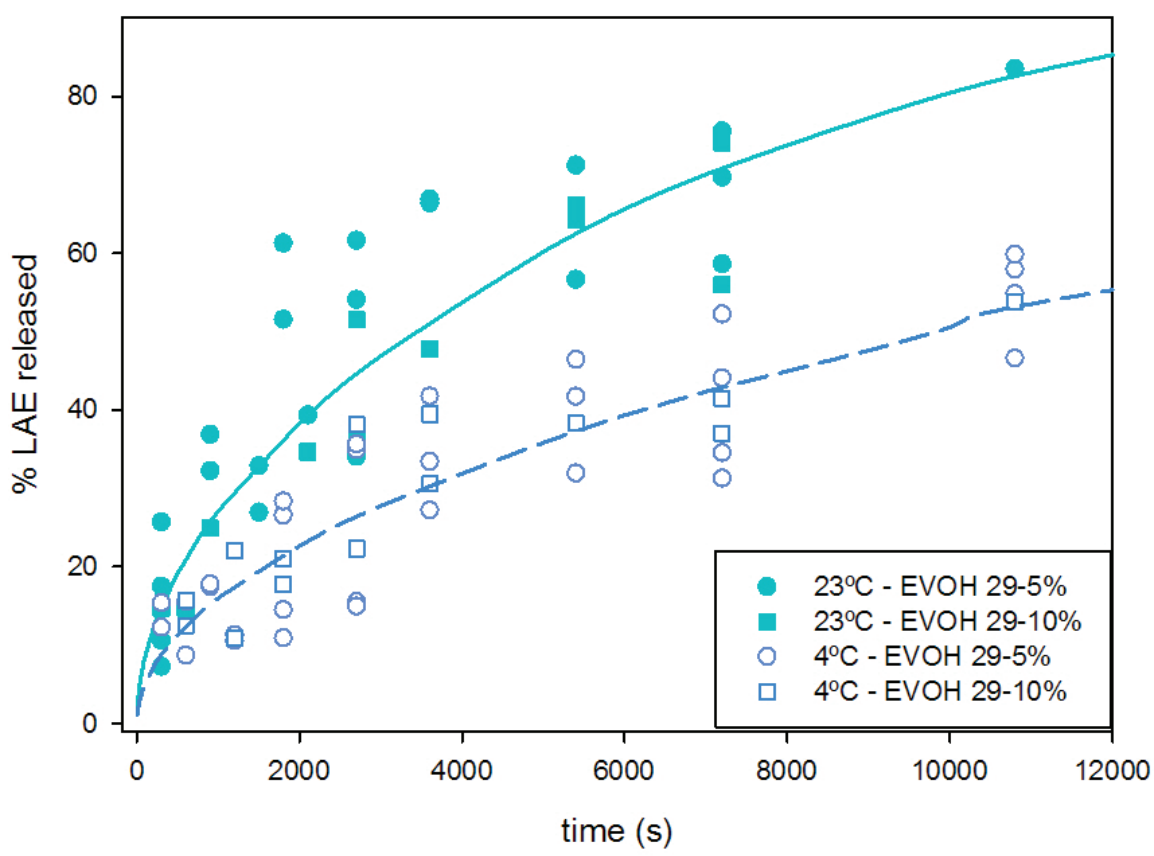

Figure 4. Release of EVOH29 with 5 and 10\% LAE at 23 and $4{ }^{\circ} \mathrm{C}$. Symbols are experimental values, and lines are the theoretical curves obtained through equation 1 with $\mathrm{D}=3.4 \times 10^{-14} \mathrm{~m}^{2} / \mathrm{s}\left(23^{\circ} \mathrm{C}\right)$ and $\mathrm{D}=1.3 \times 10^{-14} \mathrm{~m}^{2} / \mathrm{s}\left(4^{\circ} \mathrm{C}\right)$

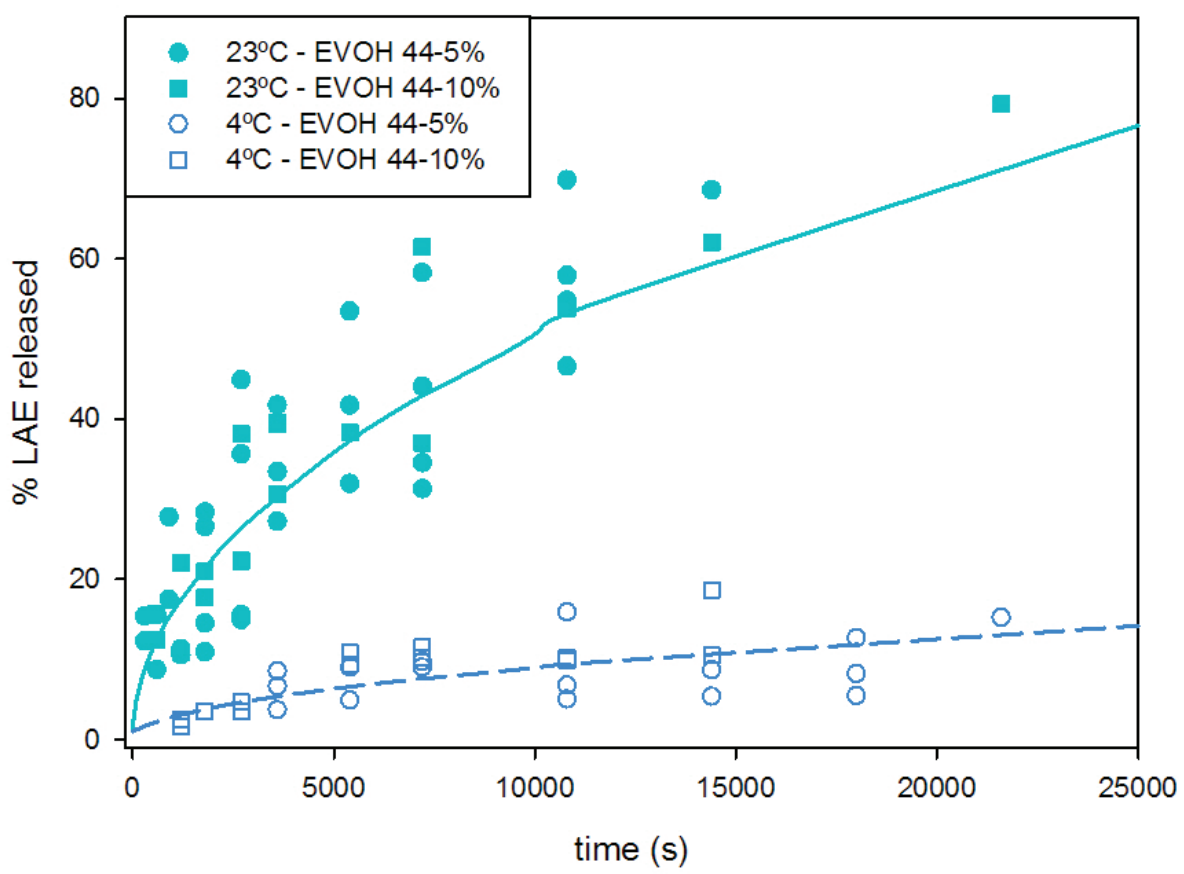

Figure 5. Release of EVOH44 with 5 and 10\% LAE at 23 and $4{ }^{\circ} \mathrm{C}$. Symbols are experimental values, and lines are the theoretical curves obtained through equation 1 with $\mathrm{D}=4.4 \times 10^{-15} \mathrm{~m}^{2} / \mathrm{s}\left(23^{\circ} \mathrm{C}\right)$ and $\mathrm{D}=1.4 \times 10^{-16} \mathrm{~m}^{2} / \mathrm{s}\left(4^{\circ} \mathrm{C}\right)$ 
compound quicker. The EVOH copolymers with higher ethylene content resulted more plasticized by water at high humidity, and mass transport was accelerated in these conditions. Thus, the mass transport of LAE in EVOH at high humidity is in agreement with the data observed in WVP and oxygen permeability at high humidities. Finally, it is noticeable that from 4 to $23{ }^{\circ} \mathrm{C}$, the effect on release is much more relevant in EVOH44 than in EVOH29 (30 fold vs 3 fold). Probably the water gain in EVOH29 and the subsequent plasticization of the polymer is similar at both temperatures, whereas EVOH44 at $4{ }^{\circ} \mathrm{C}$ is much less plasticized than at $23^{\circ} \mathrm{C}$.

This information is extremely useful to determine how likely a packaging film can hold antimicrobial substances and release them when they come in contact with food. An efficient antimicrobial package whose mechanism of action is the agent release, should assure that the minimal inhibitory concentration is reached at the right time and that it is maintained throughout the shelf life of the product. Therefore, the characterization of the release will allow an optimized design of the final active material.

\section{CONCLUSIONS}

Antimicrobial films based on EVOH films and LAE were successfully manufactured by casting. The films were continuous, transparent and their optical properties did not present relevant changes with respect to the control samples. Thermal analysis revealed that in dry conditions the incorporation of the antimicrobial agent increased the intermolecular interaction producing an antiplasticization effect and deteriorated the crystallinity structure of the film. The incorporation of LAE diminished the contact angle and the barriers to water vapor and oxygen, these latter as a consequence of the lesser and more irregular crystalline phase. The release of antimicrobial agent into water used as food simulant was quicker in EVOH29 at both temperatures. Active EVOH44 films presented a more sustained released, especially at refrigeration temperatures. Therefore, the active materials developed would provide very similar functional properties in packaging design to conventional food packaging and the different behavior in agent release can be taken advantage of to design an efficient antimicrobial food packaging.

\section{Acknowledgements}

The authors acknowledge the financial support of the European Commission (Nafispack Project) and the Spanish Ministry of Economy and Competitiveness, project AGL201239920-C03-01, and fellowship (V. M-G), and Mr. Tim Swillens (translation services). They also thanks the collaboration of ITENE (Associate Unit of CSIC) for the measurement of the optical properties (Amparo Martinez). 


\section{REFERENCES}

[1] P. Appendini, Hotchkiss, J.H.,, Review of antimicrobial food packaging, Innovative Food Science and Emerging Technologies, 3 (2002) 113-126.

[2] V. Muriel-Galet, G. Lopez-Carballo, R. Gavara, P. Hernandez-Munoz, Antimicrobial food packaging film based on the release of LAE from EVOH, International Journal of Food Microbiology, 157 (2012) 239-244.

[3] A. Oyane, M. Uchida, K. Onuma, A. Ito, Spontaneous growth of a laminin-apatite nano-composite in a metastable calcium phosphate solution, Biomaterials, 27 (2006) 167-175.

[4] S. Aucejo, R. Catala, R. Gavara, Interactions between water and EVOH food packaging films, Food Science and Technology International, 6 (2000) 159-164.

[5] V. Muriel-Galet, J.P. Cerisuelo, G. Lopez-Carballo, M. Lara, R. Gavara, P. Hernandez-Munoz, Development of antimicrobial films for microbiological control of packaged salad, International Journal of Food Microbiology, 157 (2012) 195-201.

[6] C. Lopez-de-Dicastillo, R. Catala, R. Gavara, P. Hernandez-Munoz, Food applications of active packaging EVOH films containing cyclodextrins for the preferential scavenging of undesirable compounds, Journal of Food Engineering, 104 (2011) 380-386.

[7] S.A. Ruckman, X. Rocabayera, J.F. Borzelleca, C.B. Sandusky, Toxicological and metabolic investigations of the safety of $\mathrm{N}$-alpha-lauroyll-arginine ethyl ester monohydrochloride (LAE), Food and Chemical Toxicology, 42 (2004) 245259.

[8] G. Bakal, Diaz, A., The lowdown on lauric arginate, Food Quality, (2005) 60-61.

[9] EU, Commission Regulation (EU) No. 10/2011 of 14 January 2011 on plactic materials and articles intended to come into contact with food, in, Official Journal of the European Union 2011, pp. 1-89.
[10] L. Bastarrachea, S. Dhawan, S.S. Sablani, Engineering Properties of Polymeric-Based Antimicrobial Films for Food Packaging, Food Engeneering Reviews, 3 (2011) 79-93.

[11] J.J. García Domínguez, Infante, M.R., Erra, P. and Julia, M.R. , N alpha-acil-L-alkylaminoguanidinic acids and their salts surfactants with antimicrobial action. Spanish patent, 1983.

[12] J.P. Cerisuelo, V. Muriel-Galet, J.M. Bermudez, S. Aucejo, R. Catala, R. Gavara, P. Hernandez-Munoz, Mathematical model to describe the release of an antimicrobial agent from an active package constituted by carvacrol in a hydrophilic EVOH coating on a PP film, Journal of Food Engineering, 110 (2012) 26-37.

[13] S. Aucejo, C. Marco, R. Gavara, Water effect on the morphology of EVOH copolymers, Journal of Applied Polymer Science, 74 (1999) 1201-1206.

[14] A. López-Rubio, R. Gavara, J.M. Lagarón, Unexpected partial crystallization of an amorphous polyamide as induced by combined temperature and humidity, Journal of Applied Polymer Science, 102 (2006) 1516-1523.

[15] C. Lopez-de-Dicastillo, J.M. Alonso, R. Catala, R. Gavara, P. Hernandez-Munoz, Improving the Antioxidant Protection of Packaged Food by Incorporating Natural Flavonoids into EthyleneVinyl Alcohol Copolymer (EVOH) Films, Journal of Agricultural and Food Chemistry, 58 (2010) 10958-10964.

[16] C. Lopez de Dicastillo, C. Nerin, P. Alfaro, R. Catala, R. Gavara, P. Hernandez-Munoz, Development of New Antioxidant Active Packaging Films Based on Ethylene Vinyl Alcohol Copolymer (EVOH) and Green Tea Extract, Journal of Agricultural and Food Chemistry, 59 (2011) 7832-7840.

[17] T. Yamamoto, T. Kanda, Y. Nishihara, T. Ooshima, Y. Saito, Correlation Study among Oxygen Permeability, Molecular Mobility, and Amorphous Structure Change of Poly(ethylenevinylalcohol copolymers) by Moisture, Journal of Polymer Science Part B-Polymer Physics, 47 (2009) 1181-1191. 
[18] G.G. Buonocore, M.A. Del Nobile, A. Panizza, M.R. Corbo, L. Nicolais, A general approach to describe the antimicrobial agent release from highly swellable films intended for food packaging applications, Journal Controlled Release, 90 (2003) 97-107.

[19] K.K. Mokwena, J. Tang, M.P. Laborie, Water absorption and oxygen barrier characteristics of ethylene vinyl alcohol films, Journal of Food Engineering, 105 (2011) 436-443.

[20] G. Lopez-Carballo, D. Cava, J.M. Lagaron, R. Catala, R. Gavara, Characterization of the interaction between two food aroma components, alpha-pinene and ethyl butyrate, and ethylene-vinyl alcohol copolymer (EVOH) packaging films as a function of environmental humidity, Journal of Agricultural and Food Chemistry, 53 (2005) 7212-7216. 


\section{ANTIMICROBIAL}

EFFECTIVENESS OF LAUROYL

ARGINATE INCORPORATED INTO

ETHYLENE VINYL ALCOHOL

COPOLYMERS TO EXTEND THE

SHELF LIFE OF CHICKEN STOCK

AND SURIMI STICKS

Virginia Muriel-Galet', Gracia López-Carballo', Rafael Gavara' and Pilar Hernández-Muñoz*

Food and Bioprocess Technology, 2014, 1-10 


\section{ABSTRACT}

This study was designated to determine the antimicrobial effect of ethyl-N-a-dodecanoylL-arginate hydrochloride (LAE) incorporated into ethylene vinyl alcohol copolymer $(E V O H)$ films on chicken stock and ready-to-eat surimi sticks. Firstly, the effect of LAE against Listeria monocytogenes and Echerichia coli was studied by using flow cytometry and scanning electron microscopy. Next, film-forming solutions of EVOH29 or EVOH44 (29\% and 44\% molar percentage of ethylene, respectively) containing 0, 5 and 10\% w/w of LAE were cast into films. Several experiments were conducted to determine the antimicrobial activity of the films in vitro and also in vivo with the above-mentioned food products. The outcome of the tests showed a high impact on the viability of bacteria treated with LAE, with dramatic damage to the membrane. The films were able to inhibit the microbiota of the food products studied for 10 days under storage at $4{ }^{\circ} \mathrm{C}$, showing a significant antibacterial effect against L. monocytogenes and E. coli. These films show great potential as systems for sustained release of active molecules to improve the safety and quality of packaged food products.

Keywords: Ethyl-N-dodecanoyl-L-arginate hydrochloride, ethylene vinyl alcohol copolymers; pathogenic bacteria; surimi sticks; chicken stock. 


\section{INTRODUCTION}

The strong demand for healthy, natural foods rich in proteins and low in fat has increased and they have become popular all over the world. However, food products without or with a low amount of additives undergo faster deterioration as a result of physical, chemical and biological processes. Exposure to these processes tends to modify the nutritional, physiological and/or sensory properties of foods, reducing shelflife and safety and increasing the risk of food-borne diseases. Microbiological food spoilage can be minimized and food safety ensured by means of effective control of bacterial growth. The short shelf-life of minimally processed and preservative-free refrigerated products creates a need for research into innovative food preservation technologies capable of preserving without compromising product quality.

L. monocytogenes and E. coli are common pathogens present in food products as a result of cross-contamination. L. monocytogenes is considered one of the most important bacteria of food-borne disease. The manifestations of disease include septicaemia, meningitis (or meningoencephalitis) and encephalitis, usually proceeded by symptoms similar to flu. In pregnant women it can cause spontaneous abortion. It has also been associated with gastrointestinal manifestations with fever. Although the morbidity of listeriosis is relatively low, the rate of mortality from systemic disease can be very high, with values close to 30\%. Symptoms of infection by E. coli are severe abdominal pain, severe diarrhoea, often bloody, and sometimes nausea, vomiting and mild fever. The individuals susceptible to these pathogenic bacteria include "YOPIs" (the young, the old, the pregnant and the immunocompromised) [15].
Technological innovations such as antimicrobial packaging inhibit or retard the proliferation of microorganisms in foods, thus extending the shelf-life and increasing the safety of the product [1]. Compared with direct addition of active agents to food, antimicrobial active packaging technologies could stabilize labile additives or avoid interactions and chemical reactions with other additives or ingredients during food processing, thus reducing the amount of active agent required, satisfying consumer demands [2].

In previous work, antimicrobial packaging films were produced. For this purpose, two different ethylene-vinyl alcohol copolymers (EVOH29 and EVOH44) were used as matrices to incorporate the antimicrobial agent ethyl-Na-dodecanoyl-L-arginate hydrochloride (LAE). The films that were developed presented a strong antimicrobial effect with a wide range of action, without modifying film functional properties $[3,4]$. LAE is a cationic surfactant derived from lauric acid, L-arginine, and ethanol. This new molecule has been considered as Generally Recognized as Safe (GRAS) and permitted as a food preservative at a concentration up to 200 ppm by the Food and Drug Administration (FDA) [5]. Moreover, when LAE is ingested it is hydrolysed in the human body and transformed into natural components [5-7]. Recent studies have used LAE as an antimicrobial agent to inhibit microbial growth in foods, but limited information is available concerning its use in the design of active food packaging by means of its incorporation into polymer films [7-10].

This work considers issues associated with food spoilage and the safety of refrigerated 
products such as chicken stock and readyto-eat surimi sticks after package opening. The use of heat treatment of these products can lead to deterioration of food and consumer perception of product quality owing to flavour alterations. In addition, the stipulated period of time given by the manufacturer for safe surimi and chicken stock consumption after the package is opened is two days when stored under refrigerated conditions. One way to prolong the microbiological shelf-life without modifying organoleptic properties is to improve traditional packaging by the use of the newly developed films as an inner coating of the package wall $[13,14]$. Therefore, the aim of this study is to use the newly developed antimicrobial active films to improve the microbiological safety of these products after package opening.

\section{MATERIALS AND METHODS}

\subsection{Materials}

Ethylene vinyl alcohol copolymer (EVOH) possessing a 29 and a 44\% ethylene molar content was kindly provided by The Nippon Synthetic Chemical Company (Osaka, Japan); 1-propanol was purchased from Sigma (Madrid, Spain). The antimicrobial LAE $\left(\mathrm{C}_{20} \mathrm{H}_{41} \mathrm{~N}_{4} \mathrm{O}_{3} \mathrm{Cl}\right)$ was provided by Vedeqsa Grupo LAMIRSA (Terrassa, Barcelona, Spain). Water was obtained from a Milli-Q Plus purification system (Millipore, Molsheim, France).

\subsection{Culture preparation}

Gram positive bacteria Listeria monocytogenes CECT 934 (ATTCC 19114) and Gram negative bacteria bacterium Escherichia coli CECT 434 (ATCC 25922) were selected because of their importance in foodborne illness. Strains were obtained from the Spanish Type Culture Collection (CECT, Valencia, Spain) and stored in Tryptone Soy Broth (TSB) purchased from Scharlab (Barcelona, Spain) with 20\% glycerol at $-80{ }^{\circ} \mathrm{C}$ until needed. For experimental use, the stock cultures were maintained by regular subculture on Tryptone Soy Agar (TSA) (Scharlab, Barcelona, Spain) slants at $4{ }^{\circ} \mathrm{C}$ and transferred monthly. Prior to the experiments, a loopful of each strain was transferred to $10 \mathrm{~mL}$ of TSB and incubated at $37^{\circ} \mathrm{C}$ for $18 \mathrm{~h}$ to obtain early-stationary phase cells.

\subsection{Antimicrobial capacity of LAE}

\subsubsection{Flow cytometry}

The minimum inhibitory concentration (MIC) - considered as the lowest concentration needed to inhibit visible growth of the microorganism - of LAE was tested against L. monocytogenes and E. coli in a previous work [3]. Dilutions of LAE in peptone water were added to $10 \mathrm{~mL}$ of TSB in order to reach a final concentration corresponding to the MIC value, $7 \mathrm{ppm}$ and $20 \mathrm{ppm}$ for L. monocytogenes and E. coli, respectively. Briefly, $100 \mu \mathrm{L}$ of each microorganism in exponential phase was inoculated in each test tube and incubated for $24 \mathrm{~h}$ at $37^{\circ} \mathrm{C}$. After this time, the samples were centrifuged and resuspended twice in saline solution $(0.8 \% \mathrm{NaCl})$. The cells were stained with the cell-permeant double-stranded DNA fluorochrome SYTO-13 (Molecular Probes Europe BV, Netherlands) and with propidium iodide solution (PI, Calbiochem). SYTO-13 stains the nucleic acids in all cells, while PI stains the nucleic acids in cells with a damaged membrane. The studies were conducted in the Central Service for 
Experimental Research at the University of Valencia (Spain), performed with a BD FACSVerse ${ }^{\mathrm{TM}}$ (Becton Dickinson, USA) flow cytometer. Each cell was characterized by four optical parameters: side scatter (SSC), forward scatter (FSC), green fluorescence for SYTO-13 (excitation light $497 \mathrm{~nm}$ and emission light $520 \mathrm{~nm}$ ), and red fluorescence for PI (excitation light $493 \mathrm{~nm}$ and emission light $630 \mathrm{~nm}$ ). The software BD FACS Suite v. 1.0.3.2924 (Becton Dickinson, USA) was used to collect the data.

An untreated control of both pathogens was also analysed.

\subsubsection{Scanning electron microscopy}

The minimum bactericidal concentration (MBC) - defined as the concentration at which no growth is observed after plating onto agar - values described in previous works, $12 \mathrm{ppm}$ for L. monocytogenes and $32 \mathrm{ppm}$ for E. coli, were placed in contact with $10 \mathrm{~mL}$ of TSB and $100 \mu \mathrm{L}$ of L. monocytogenes and E. coli in exponential phase and were inoculated in each test tube and incubated for $24 \mathrm{~h}$ at $37^{\circ} \mathrm{C}$. Untreated controls of both pathogens were prepared. The samples were centrifuged and resuspended twice in saline solution $(0.8 \% \mathrm{NaCl})$. Each suspension was filtered through a 0.2-mm Nuclepore Track-Etch Membrane (Whatman, UK), and the membranes were dehydrated in 30\%, 50\%, 70\%, 90\% and 100\% graded alcohol series. A small amount of platinum was sputtered on the samples to avoid charging in the microscope. SEM observation of L. monocytogenes and E. coli was performed in the Central Service for Experimental Research at the University of Valencia (Spain) with an electron microscope (HITACHI S 4100) working at 10 $\mathrm{kV}$.

\subsection{Film preparation}

EVOH films were prepared as described in previous works $[3,4]$. Briefly, the film for- ming solution was prepared by dissolving EVOH 29 in a 1:1 (v:v) 1-propanol:water mixture at $50{ }^{\circ} \mathrm{C}$ and $\mathrm{EVOH} 44$ in a 2:1 (v:v) 1-propanol:water mixture at the same temperature. The solution was stirred for 30 min using a magnetic stirrer. After that time, a concentration of 5 and 10\% LAE was added and stirred again for about 15 min. The films were prepared by casting; $5 \mathrm{~mL}$ of each film-forming solution was extended over a glass plate using an extension bar, and placed in a drying tunnel equipped with a $2500 \mathrm{~W}$ heat source for 10 min until it was completely dry. Films prepared without LAE were used as controls. Film thickness was measured using a Mitutoyo micrometer (Osaka, Japan) and had an average value of $15 \pm 2 \mu \mathrm{m}$. Finally, the films were stored in glass desiccators containing silica gel at $22^{\circ} \mathrm{C}$ prior to use.

\subsection{Effectiveness of antimicrobial EVOH films with LAE against $L$. monocytogenes and $E$. coli in vitro}

The antimicrobial activity of the EVOH29 and EVOH44 films with 5 and 10\% of LAE were tested in vitro against L. monocytogenes and E. coli using an agar diffusion method. For this purpose, $100 \mu \mathrm{L}$ of a bacteria suspension containing approximately $10^{7} \mathrm{CFU} / \mathrm{mL}$ was spread over the TSA surface. Disks of the antimicrobial films (40 $\mathrm{mm}$ in diameter) were attached to the Petri dish in direct contact with the microorganism. Plates were incubated at $37^{\circ} \mathrm{C}$ for 24 $h$ and the diameter of the resulting inhibition zone in the bacterial lawn was measured. Control films (EVOH29 and EVOH44) without LAE were also tested. The experiment was carried out in triplicate.

\subsection{Food samples: chicken stock and suri- mi sticks}

Chicken stock was produced according to the traditional method using a WMF Perfect pressure cooker (Germany). The ingredients employed were chicken (500g), 
carrots (2 pieces), onion (1 piece), leek (1piece), water (1 L) and salt, and they were purchased from a local supermarket. Firstly, chicken was cut into pieces and fried lightly with chopped vegetables for $5 \mathrm{mi}$ nutes, after that, water and salt was added to the pot and cooked under pressure for 8 min. After cooking, the chicken stock was cooled at room temperature for $20 \mathrm{~min}$ and then kept at $4^{\circ} \mathrm{C}$.

Surimi sticks were also purchased from a local supermarket in Valencia, Spain. The product contained $2.5 \mathrm{~g}$ of total fat, $12.9 \mathrm{~g}$ of total carbohydrate and $8.4 \mathrm{~g}$ of total protein, and was labelled as free of preservatives. The samples were transported to the laboratory under refrigerated conditions and kept at $4{ }^{\circ} \mathrm{C}$ until the experimental assays.

\subsection{Antimicrobial activity of EVOH29 and EVOH44 films with LAE against microbio- ta of chicken stock and surimi sticks}

Sterilized tubes were prepared with $10 \mathrm{~mL}$ of chicken stock produced under sterile conditions; and $0.25 \mathrm{~g}$ of film containing $5 \%$ or $10 \%$ of LAE cut into pieces measuring $1.5 \mathrm{~cm}^{2}$ was immersed in $10 \mathrm{~mL}$ of chicken stock. Liquid food samples in contact with EVOH29 and EVOH44 without LAE and samples without film were used as controls. The tubes were stored for 10 days at $4{ }^{\circ} \mathrm{C}$. Analyses were performed on the $2^{\text {nd }}, 6^{\text {th }}$ and $10^{\text {th }}$ days of storage. Serial dilutions in peptone water (Scharlab, Barcelona, Spain) were plated on specific media (Scharlab, Barcelona, Spain) with the following culture conditions: a) Violet Red Bile Glucose agar for total enterobacteria, incubated at $37^{\circ} \mathrm{C}$ for 24 h; b) Man, Rogosa and Sharpe agar for lactic acid bacteria, incubated at $25{ }^{\circ} \mathrm{C}$ for 5 days; c) Nutrient Agar for total aerobic bacteria, incubated at $37^{\circ} \mathrm{C}$ for $48 \mathrm{~h}$; d) Nutrient Agar for total aerobic psychrotrophic bacteria, incubated at $10^{\circ} \mathrm{C}$ for 10 days; f) King $\mathrm{B}$ agar for Pseudomonas, incubated at $30^{\circ} \mathrm{C}$ for $48 \mathrm{~h}$. The counts were performed in triplicate and expressed as log CFU/mL.

Individual pieces (ca. 25 g) of surimi stick were wrapped with EVOH29 films and EVOH44 films containing $5 \%$ or $10 \%$ of LAE. Samples without film and samples wrapped with EVOH29 and EVOH44 films without LAE were prepared as controls. The wraps covered and touched all surfaces of the surimi. The samples were stored at 4 ${ }^{\circ} \mathrm{C}$ for 10 days. The antimicrobial activity of the films was determined on the $2^{\text {nd }}, 6^{\text {th }}$ and $10^{\text {th }}$ days after wrapping the samples. At appropriate times, samples were transferred aseptically in a sterile Stomacher bag, diluted with $25 \mathrm{~mL}$ of peptone water (Scharlab, Barcelona, Spain) for 3 min using a Stomacher (IUL S.L., Barcelona). Serial dilutions were plated on specific media with the culture conditions described above.

\subsection{Antimicrobial efficacy of EVOH29 and EVOH44 films with LAE in chicken stock and on surimi sticks inoculated with $L$. monocytogenes and E. coli}

First, $100 \mu \mathrm{L}$ of cell culture of each microorganism in stationary phase, with an optical density of 0.9 at 600 nm, was diluted in $10 \mathrm{~mL}$ of TSB and incubated at 37 ${ }^{\circ} \mathrm{C}$ until exponential phase was reached, corresponding to an optical density of 0.2 at $600 \mathrm{~nm}\left(10^{5} \mathrm{CFU} / \mathrm{mL}\right)$ measured with an Agilent 8453 UV-visible spectrophotometer (Barcelona, Spain) using TSB as blank. Then $100 \mu \mathrm{L}$ of pathogenic bacteria in exponential phase was inoculated under sterile conditions into $10 \mathrm{~mL}$ of chicken stock contained in sterilized tubes, after which $0.25 \mathrm{~g}$ of each antimicrobial film sample was immersed. Liquid food samples without film and samples with film without incorporating LAE were used as controls. The tubes were stored for 10 days at $4{ }^{\circ} \mathrm{C}$. Analyses were performed on the $2^{\text {nd }}, 6^{\text {th }}$ and $10^{\text {th }}$ days of storage. Serial dilutions were made and plated on selective media: Palcam Listeria Selective Agar for 
L. monocytogenes and Brilliant Green Agar for E. coli (Scharlab, Barcelona, Spain).

Surimi sticks were surface inoculated with $100 \mu \mathrm{L}$ of each pathogenic microorganism in exponential phase $\left(10^{5} \mathrm{CFU} / \mathrm{mL}\right)$. The inoculums were dispersed separately on the surface with a sterile pipette and wrapped as described in the previous section. Surimi stick samples wrapped in film without LAE and samples wrapped in aluminium foil were used as controls. Testing of bacterial growth in surimi sticks was performed on the $2^{\text {nd }}, 6^{\text {th }}$ and $10^{\text {th }}$ days after wrapping the samples. Serial dilutions were carried out and plated on the same selective media.

Colonies were counted after incubation at $37^{\circ} \mathrm{C}$ for $24 \mathrm{~h}$. Counts were performed in triplicate and expressed as log CFU/mL.

\subsection{Analysis of LAE availability}

A test to ensure the absence of LAE after gastrointestinal digestion was conducted at the end of the sample storage time. For this purpose, samples of chicken stock and surimi sticks stored in contact with EVOH29 and EVOH44 containing 10\% of LAE were analysed. A two-step procedure was carried out. First, a gastrointestinal digestion study was performed, and then the qualitative analysis of LAE was carried out using High Performance Liquid Chromatography (HPLC) coupled with UV-Vis detection.

Gastrointestinal digestion was carried out by dissolving $10 \mathrm{~g}$ of each sample (chicken stock and surimi sticks) in water to a final volume of $80 \mathrm{~g}$. The $\mathrm{pH}$ was adjusted to 2 and fresh pepsin solution (10\% pepsin in $0.1 \mathrm{M} \mathrm{HCl}$ ) was added. The pepsin- $\mathrm{HCl}$ digestion was carried out for $2 \mathrm{~h}$ (to simulate gastric digestion), incubated in a shaking water bath at $37^{\circ} \mathrm{C}$. After the pepsin digestion, the $\mathrm{pH}$ was adjusted to 7.4 and the pancreatin bile extract solution mixture (0.2 g of pancreatin and $1.25 \mathrm{~g}$ of bile extract in $50 \mathrm{~mL}$ of $0.1 \mathrm{M} \mathrm{NaHCO}_{3}$ ) was added and incubated in a shaking water bath at $37^{\circ} \mathrm{C}$ for $2 \mathrm{~h}$. The experiment was performed in triplicate for each sample. Samples exposed to EVOH films without LAE and samples with a known amount of LAE (200 ppm) directly added to the digestion solution were also measured.

After gastrointestinal digestion, the samples were filtered and LAE was determined by HPLC coupled with a UV-Vis absorbance detector. An Agilent 1200 series HPLC system equipped with a $\mathrm{C} 18$ reversed-phase column $(150 \times 3.9 \mathrm{~mm}, 5 \mu \mathrm{m})$ and a Model G1513A DAD was used and the absorbance data were recorded at $205 \mathrm{~nm}$. The mobile phase was acetonitrile:water 50:50 $(\mathrm{V} / \mathrm{v})$ containing $0.1 \%$ trifluoroacetic acid, the flow rate $1 \mathrm{ml} / \mathrm{min}$, the temperature 23 ${ }^{\circ} \mathrm{C}$ and the injection volume was $20 \mu \mathrm{L}$. A preliminary calibration was performed by injecting known amounts of LAE.

\subsection{Statistical analysis}

One-way analyses of variance were carried out using the SPSS ${ }^{19}$ computer program (SPSS Inc., Chicago, IL, USA). Differences in pairs of mean values were evaluated by the Tukey test for a confidence interval of 95\%. Data are represented as mean \pm standard deviation. 


\section{RESULTS AND DISCUSSION}

\subsection{Antimicrobial capacity of LAE}

\subsubsection{Flow cytometry analysis}

Flow cytometry analyses the viability of cells. With suitable fluorochromes it is possible to distinguish between a viable and a non-viable cell population to assess the antimicrobial effect of LAE. In previous studies conducted in our laboratory, the
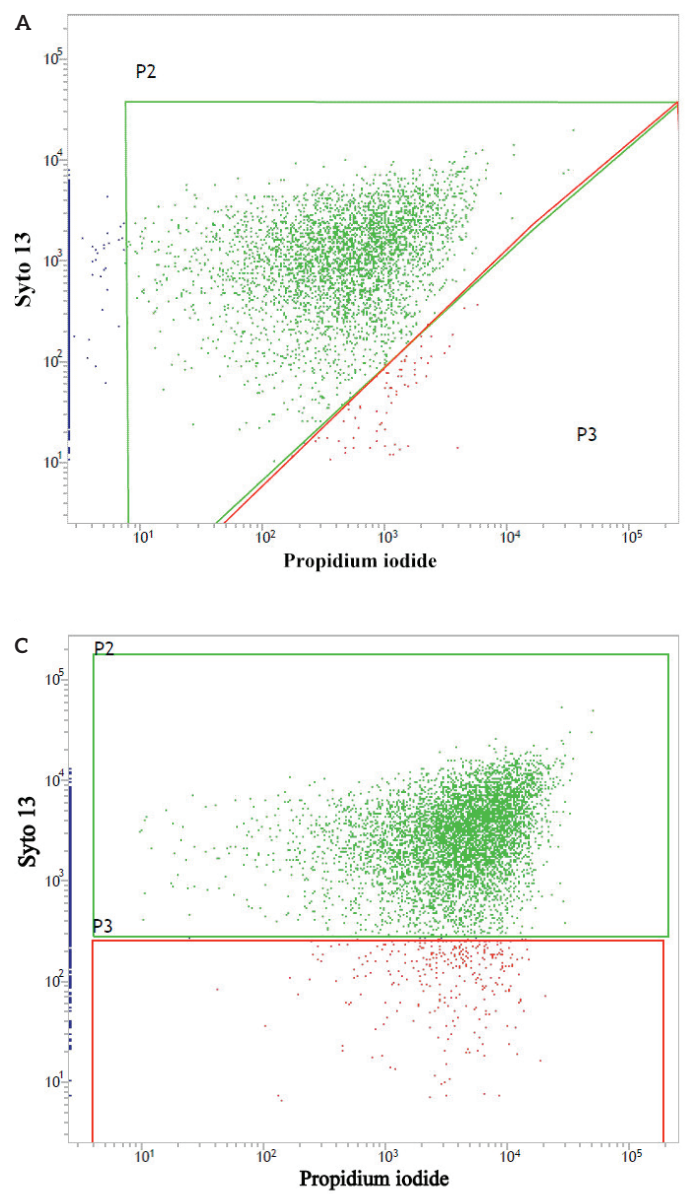

minimum inhibitory concentration (MIC) of LAE against L. monocytogenes and $E$. coli [3] was determined. In the present study, flow cytometry was used to confirm the MIC values. The results obtained for L. monocytogenes and E. coli are shown in Fig 1. In both cases the samples were successfully stained. The positive control of $L$. monocytogenes presented $83.29 \%$ of total cells, representing $70 \%$ of live cells stained
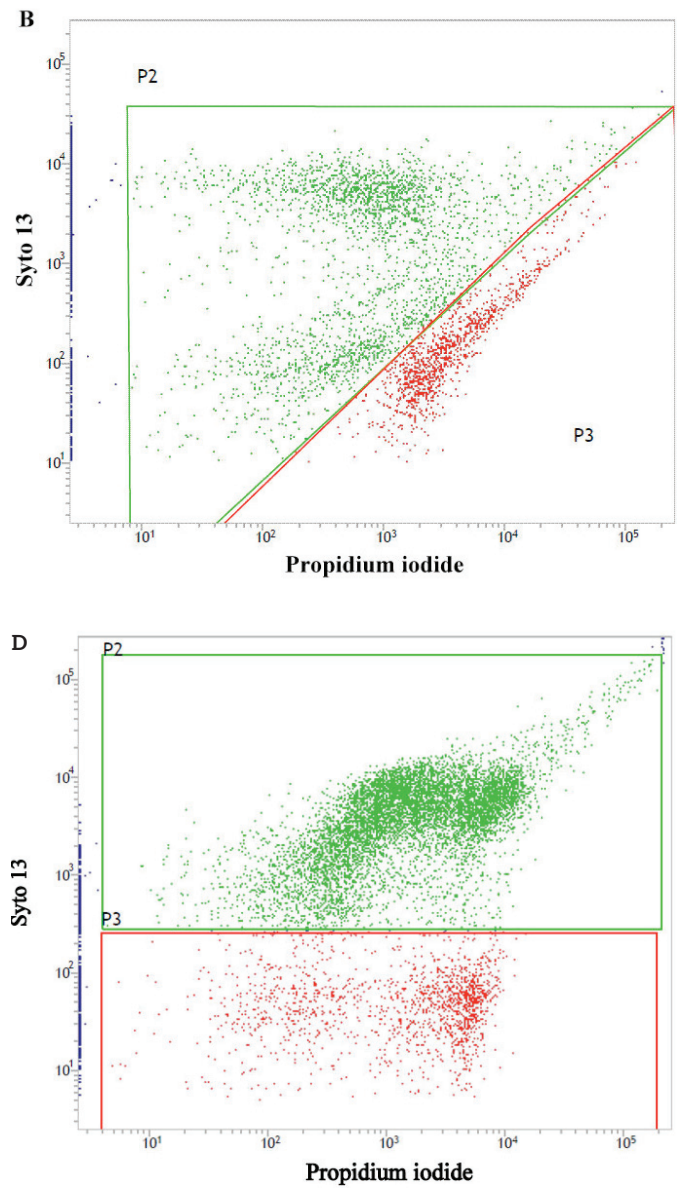

Figure 1. Dual-parameter SYTO-13/PI fluorescence histograms obtained by staining L. monocytogenes a) control samples; b) cells after MIC treatment; and E. coli c) control samples; d) cells after MIC treatment. 
with SYTO-13 and 3.29\% of dead cells stained with PI (Fig 1A). SYTO-13 penetrates all types of cellular membranes and binds nucleic acids of the cell, whereas PI only penetrates the bacterial membrane when the membrane is damaged [11]. The percentage of cell death in the control is due to different phases of cellular cycle. After being treated with $7 \mathrm{ppm}$ of LAE, damaged L. monocytogenes cells became visible, with a dead population of 23.35\% (Fig 1B). With regard to E. coli, the untreated control presented $81.90 \%$ of live cells stained with SYTO-13 and $4.28 \%$ of dead cells stained with PI. After being treated with $20 \mathrm{ppm}$ of LAE the damaged cells became visible, with a dead population of 17.79\% (Fig 1D). This study demonstrated that the percentage of damaged cells after exposure to an
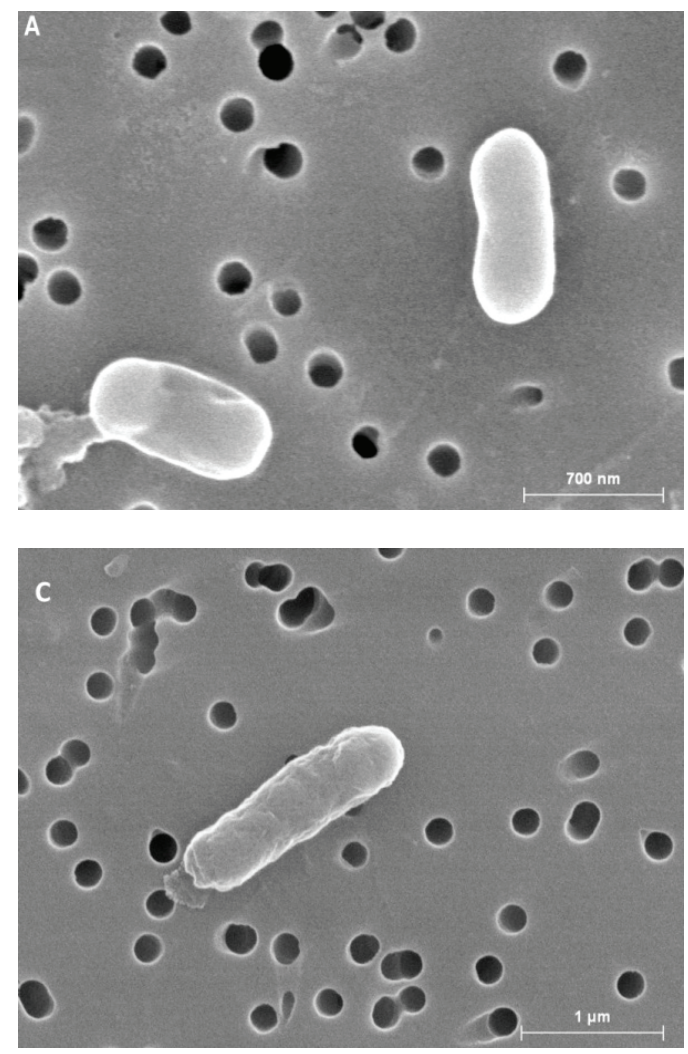

LAE concentration corresponding to the MIC was in accordance with inhibition growth results obtained in a previous work [3]. From these results and supporting previous results it can be stated that LAE is slightly more active against Gram positive bacteria than against Gram negative bacteria.

\subsubsection{Scanning electron microscopy (SEM)}

In order to determine the morphological changes resulting in the membrane structure of L. monocytogenes and E. coli, cells were observed by SEM after being exposed to the minimum bactericidal concentration (MBC) of LAE, $12 \mathrm{ppm}$ and $32 \mathrm{ppm}$, respectively. Untreated L. monocytogenes and E. coli cells displayed a smooth, intact surface
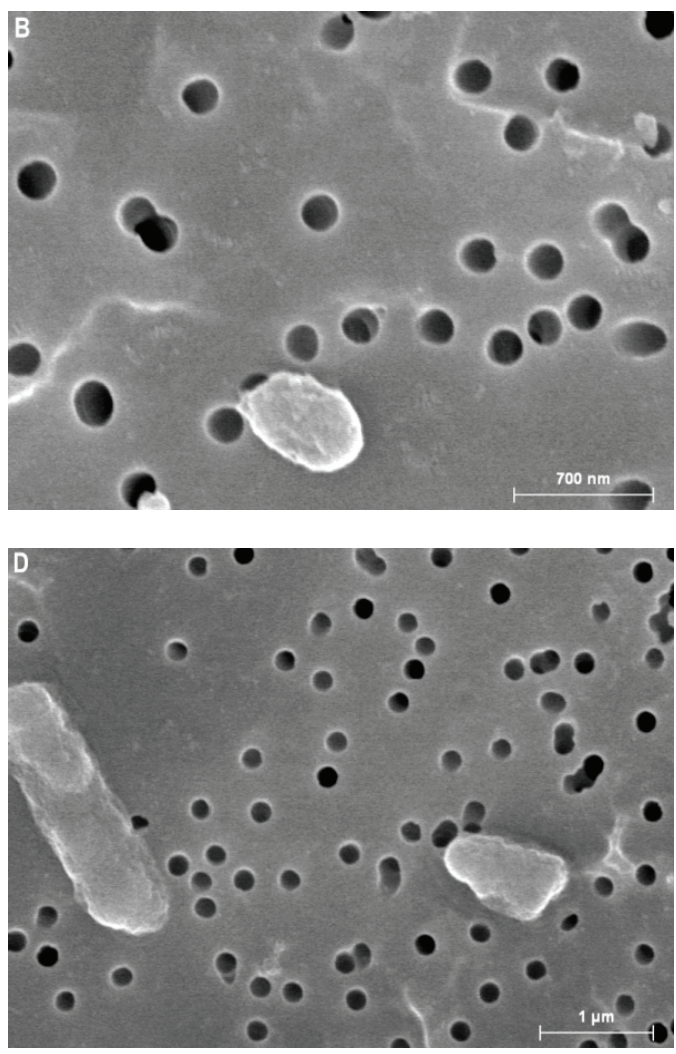

Figure 2. Scanning electron micrographs of pathogen cells: a) L. monocytogenes control sample and b) L. monocytogenes treated with $12 \mathrm{ppm}$ of LAE, c) E. coli control sample and d) E. coli treated with $32 \mathrm{ppm}$ of LAE. 
as observed in the micrographs (Fig 2A and $2 \mathrm{C})$. The outer membrane that surrounds the cell wall of Gram negative bacteria can also be observed (Fig 2C) The membrane of the cells that were in contact with the corresponding MBC of LAE was seriously damaged and they had an irregular rough surface, compromising cell integrity (Fig 2B and 2D).

Micrographs showed that LAE produced important changes in the cell envelope, indicating that membranes are the main target, producing disruption and instability of the plasma membrane, and presenting more activity against Gram positive bacteria than against Gram negative bacteria according to results obtained by other authors [11]. LAE interacts with lipids from the bacterial membranes, generating changes in membrane potential and bacterial structure in Gram negative bacteria [11]. Cell lysis was not observed.

\subsection{Effectiveness of antimicrobial EVOH films with LAE against L. monocytogenes and $E$. coli in vitro}

The antimicrobial activity of EVOH29 and EVOH44 films with 5 and 10\% of LAE was studied by the agar diffusion method. Table 1 shows the results obtained for the films against the two microorganisms tested. Growth inhibition appeared as a clear halo around the film, with the inhibition zone of L. monocytogenes proving to be greater than the one produced in E. coli. It was also observed that for L. monocytogenes the inhibition zone increased with the amount of LAE incorporated into the film, with values of $46.30 \mathrm{~mm}$ and $50.00 \mathrm{~mm}$ for EVOH29 incorporating 5 and 10\% of LAE, respectively. This difference decreased for EVOH44 films incorporating 5 and 10\% of LAE, which indicates that the amount of antimicrobial released from this copolymer is not enough to cause differences in growth inhibition zone related to the concentrations tested.

No differences were observed in the inhibition zones produced by EVOH29 and EVOH44 films incorporating 5 and 10\% of LAE against E. coli. Probably, the different amounts released in these samples were not enough to produce a differential effect. In the previous section it was demonstrated that the MIC of LAE is higher against Gram negative bacteria than against Gram positive bacteria, because the outer membrane of the cell wall provides a greater defence system and less susceptibility to the action of the antimicrobial compound [3].

The inhibition zone formed around EVOH29 or EVOH44 with 5 and 10\% of LAE can be explained by the high relative humidity (90\% RH) produced in the headspace of the system because of the presence of agar, triggering the release of the

Table 1. Antimicrobial effectiveness of EVOH29 and EVOH44 films incorporating several amounts of LAE against L. monocytogenes and E. coli, expressed as mm of growth inhibition zone. Values are means and standard deviation of three samples.

Inhibition zone (mm)

\begin{tabular}{rcc}
\hline & L. monocytogenes & E. coli \\
\hline EVOH29-0\% & No inhibition zone & No inhibition zone \\
\hline EVOH29-5\% & $46.3 \pm 0.3$ & $44.5 \pm 0.2$ \\
\hline EVOH29-10\% & $50.0 \pm 0.5$ & $44.5 \pm 0.5$ \\
\hline EVOH44-0\% & No inhibition zone & No inhibition zone \\
\hline EVOH44-5\% & $46.5 \pm 0.2$ & $42.0 \pm 0.6$ \\
\hline EVOH44-10\% & $48.0 \pm 0.3$ & $43.0 \pm 0.5$ \\
\hline
\end{tabular}


antimicrobial compound. In general, the highest inhibition zone values were observed with EVOH29: the more hydrophilic nature of that copolymer compared with EVOH44, conferred by a higher content of - $\mathrm{OH}$ groups, favours greater plasticization of the polymer matrix by environmental moisture, facilitating the release of LAE to the agar medium.

\subsection{Antimicrobial activity of EVOH films incorporating LAE applied to chicken stock and surimi sticks}

After confirming the antimicrobial effectiveness of the EVOH29 and EVOH44 films with 5 and 10\% of LAE a new study was carried out with the objective of testing the microbiota of chicken stock and surimi sticks against two pathogenic bacteria: L. monocytogenes and E. coli. All the samples were stored at $4^{\circ} \mathrm{C}$, simulating commercial conditions.

\subsubsection{Chicken stock and surimi stick micro- biota counts}

Chicken stock samples in contact with the films that had been developed were subjected to microbiological analysis for 10 days; samples were analysed on the $2^{\text {nd }}, 6^{\text {th }}$ and $10^{\text {th }}$ days. In all the samples analysed, no growth was observed for enterobacteria, acid lactic bacteria, psychrotrophic bacteria, yeast or moulds. It must be pointed out that no differences were found between the controls, EVOH29 or EVOH44 without LAE and samples without film (data not shown).

Pseudomonas growth was observed after the $2^{\text {nd }}$ day. Values of $1.78 \pm 0.01,2.18 \pm$ 0.063 and $3.34 \pm 0.056$ log were obtained for the control tubes on days 2, 6 and 10, respectively. Total inhibition was found with EVOH29 and EVOH44 incorporating 5 and $10 \%$ of LAE during the entire storage time.
A similar effect on total aerobic count was obtained. Values of $2.05 \pm 0.070,6.25 \pm$ 0.15 and $7.15 \pm 0.20$ log for days 2,6 and 10 , respectively, were observed in the control samples, and total inhibition was observed with the EVOH29 and EVOH44 samples containing 5 and 10\% of LAE during the entire storage time.

Levels of Pseudomonas and total aerobic count can be used as indicators of microbiological quality [2]. Pseudomonas is a predominant spoilage bacteria in food stored aerobically under refrigeration conditions. No studies were found in the literature regarding the level of spoilage bacteria that can confidently be associated with changes in organoleptic properties of chicken stock.

Surimi sticks were individually wrapped with EVOH29 and EVOH44 films with 5 and $10 \%$ of LAE. Samples without film and samples wrapped with films without LAE were prepared as controls. The samples were subjected to microbiological analysis on the $2^{\text {nd }}, 6^{\text {th }}$ and $10^{\text {th }}$ days of refrigerated storage. Again, no differences were found between unwrapped samples and samples wrapped in film without LAE (data not shown). In all the control samples analysed, no growth was observed for enterobacteria, yeast and moulds during the whole storage time. However, common bacteria for seafood, such as lactic acid bacteria, appeared in the control samples, with values of $3.24 \pm 0.21$ on the $2^{\text {nd }}$ day of storage, maintaining this concentration until the end of the assay. With regard to the total aerobic count, growth was observed after the $2^{\text {nd }}$ day. Values of $2.38 \pm 0.13,3.45 \pm 0.21$ and $3.52 \pm 0.21$ log were obtained for the control tubes on days 2, 6 and 10, respectively. Psychrotrophic bacteria, the major group of microorganisms responsible for aerobic spoilage of fish stored at refrigeration temperatures [12], proliferated in the control samples on the $2^{\text {nd }}$ day of storage, with values of $2.53 \pm 0.34$, increasing to $6.04 \pm$ 0.12 on the $10^{\text {th }}$ day. Finally, Pseudomonas 
proliferation in the surimi samples was detected in the control samples on the $6^{\text {th }}$ day of storage, with values of $3.45 \pm 0.63$, maintaining this value until the end of the storage time.

Total inhibition throughout the storage time was observed for all the microorganisms tested when the product was exposed to EVOH29 and EVOH44 containing 5 and $10 \%$ of LAE.

The use of heat treatment can lead to deterioration of food and consumer perception of product quality owing to flavour alterations. One way to prolong the microbiological shelf-life without modifying organoleptic properties is to improve traditional packaging by the use of the newly developed films as an inner coating of the package wall $[13,14]$.

The differences in the bacterial growth observed between chicken stock and surimi sticks are caused by intrinsic and extrinsic factors, such as moisture content, $\mathrm{pH}$, food composition, etc. These factors influence the growth of specific bacteria (Pseudomonas, acid lactic bacteria, psychrotrophic bacteria, yeast or moulds, etc.) in the food products.
Chicken stock and surimi sticks do not usually present a high number of microorganisms because they are subjected to a high temperature during processing. Moreover, in the case of commercial UHT chicken stock high levels of additives are added to the product, which is very different from traditional home-made stock. The microbiological shelf-life after package opening is $48 \mathrm{~h}$ when stored under refrigeration temperatures. To control undesirable microorganisms in food products after the package has been opened, LAE can be incorporated into the polymer matrix to increase food safety.

\subsubsection{Efficacy of EVOH films with LAE against L. monocytogenes and E. coli inocu- lated into chicken stock and surimi sticks}

Tubes containing films in contact with $10 \mathrm{~mL}$ of chicken stock inoculated with L. monocytogenes and E. coli and stored for 10 days at $4{ }^{\circ} \mathrm{C}$ were tested for bacterial growth. The analysis performed after 2 days of storage showed total inhibition against both pathogens in all the samples exposed to EVOH29 and EVOH44 films containing $10 \%$ of LAE. EVOH29 and EVOH44 films with 5\% of LAE produced reductions of 5.37 and $5.48 \mathrm{log}$, respectively,

Table 2. Antimicrobial activity of EVOH29 and EVOH44 films with 5 and 10\% of LAE in surimi sticks inoculated with L. monocytogenes during 10 days of storage at $4{ }^{\circ} \mathrm{C}$ expressed as logarithm of colony forming units (Log (CFU/g)) and log reduction value (LRV).

\section{L. monocytogenes}

\begin{tabular}{rcccccc}
\hline & \multicolumn{2}{c}{ Day 2 } & \multicolumn{2}{c}{ Day 6 } & \multicolumn{2}{c}{ Day 10 } \\
\hline & $\begin{array}{c}\text { Log(CFU/g } \\
\text { surimi) }\end{array}$ & LRV & $\begin{array}{c}\text { Log(CFU/g } \\
\text { surimi) }\end{array}$ & LRV & $\begin{array}{c}\text { Log(CFU/g } \\
\text { surimi) }\end{array}$ & LRV \\
\hline CONTROL & $6.00 \pm 0.02 c$ & ---- & $7.09 \pm 0.05 c$ & & $8.29 \pm 0.02 c$ & $-\cdots$ \\
\hline EVOH29-5\% & $5.07 \pm 0.03 b$ & 0.93 & $4.67 \pm 0.09 \mathrm{~b}$ & 2.42 & $3.98 \pm 0.02 \mathrm{a}$ & 4.31 \\
\hline EVOH29-10\% & $3.91 \pm 0.15 \mathrm{a}$ & 2.08 & $2.93 \pm 0.04 \mathrm{a}$ & 4.13 & $2.97 \pm 0.04 \mathrm{a}$ & 5.42 \\
\hline EVOH44-5\% & $6.15 \pm 0.02 \mathrm{c}$ & ---- & $6.28 \pm 0.01 \mathrm{c}$ & 0.80 & $6.34 \pm 0.01 \mathrm{~b}$ & 1.95 \\
\hline EVOH44-10\% & $4.23 \pm 0.03 \mathrm{a}$ & 1.77 & $4.93 \pm 0.01 \mathrm{~b}$ & 2.16 & $5.04 \pm 0.02 \mathrm{~b}$ & 3.25 \\
\hline
\end{tabular}

${ }^{a-c}$ Different letters in the same column indicate significant differences in antimicrobial effectiveness of different EVOH films (Turkey's adjusted analysis of variance, $P<0.05$ ). 
compared with the control. As has been demonstrated in previous studies, in spite of releasing the same amount of LAE to water as food simulant, EVOH29 releases it faster than EVOH44 because it is more plasticized by water [4]. In the remaining days, a bactericidal effect was observed in all the samples regardless of the copolymer used (EVOH29 or EVOH44). This maximum in microbial growth reduction is probably reached as a result of the release of LAE and the amount of LAE accumulated in the chicken stock during the storage time. The control sample of L. monocytogenes reached values of $8.31 \pm 0.01$ log after 10 days at $4{ }^{\circ} \mathrm{C}$. The $\mathrm{pH}$ between 6 and 6.5 , the nutrient characteristics of chicken stock and the classification of psychrotrophic pathogens contribute to the growth of $L$. monocytogenes at refrigeration temperature. In contrast, the growth of E. coli, a mesophilic pathogen, was reduced significantly at refrigeration temperatures: the samples maintained bacterial counts around $6 \pm 0.02$ log throughout the experiment.

Surimi sticks were surface inoculated with L. monocytogenes and E. coli and wrapped in EVOH29 and EVOH44 films with 5 and $10 \%$ of LAE as described above. Table 2 shows the antimicrobial effect of these films against L. monocytogenes compared with control samples. After the $2^{\text {nd }}$ day of storage, a significant antimicrobial effect was shown by the EVOH29 and EVOH44 films with LAE. At the end of the storage period, after 10 days, all the samples produced significant inhibition compared with the control. Again, sustained release of LAE throughout the storage time and accumulation in the food sample gave rise to microbial reduction compared with the control.

Again, no differences were found between the controls in both assays (data not shown). Table 3 shows the inhibitory effect of the films against $E$. coli inoculated into surimi sticks. On the $2^{\text {nd }}$ day of storage, the release of LAE produced a reduction of $1 \mathrm{log}$ in the samples wrapped in EVOH29 and EVOH44 with $10 \%$ of LAE. On the $6^{\text {th }}$ day of storage, a significant decrease appeared in all the samples: the EVOH29 5 and 10\% LAE samples had reductions of $1.36 \log$ and $2.37 \mathrm{log}$, respectively, and the EVOH44 5 and 10\% LAE samples had reductions of $1.11 \log$ and $2.15 \log$ respectively, results that were maintained until the end of the experiment.

It is worth pointing out that the effectiveness of the antimicrobial films varied depending on the food matrix, being more

Table 3. Antimicrobial activity of EVOH29 and EVOH44 films with 5 and 10\% of LAE in surimi sticks inoculated with E. coli during 10 days of storage at $4{ }^{\circ} \mathrm{C}$ expressed as logarithm of colony forming units (Log (CFU/g)) and log reduction value (LRV).

E. coli

\begin{tabular}{ccccccc}
\hline & \multicolumn{2}{c}{ Day 2 } & \multicolumn{2}{c}{ Day 6 } & \multicolumn{2}{c}{ Day 10 } \\
\hline & $\begin{array}{c}\text { Log(CFU/g } \\
\text { surimi) }\end{array}$ & LRV & $\begin{array}{c}\text { Log(CFU/g } \\
\text { surimi) }\end{array}$ & LRV & $\begin{array}{c}\text { Log(CFU/g } \\
\text { surimi) }\end{array}$ & LRV \\
\hline CONTROL & $6.12 \pm 0.04$ & & $6.22 \pm 0.02$ & & $6.63 \pm 0.06$ & \\
\hline EVOH29-5\% & $5.96 \pm 0.04$ & --- & $4.86 \pm 0.04$ & 1.36 & $5.33 \pm 0.06$ & 1.30 \\
\hline EVOH29-10\% & $4.98 \pm 0.14$ & 1.23 & $3.85 \pm 0.05$ & 2.37 & $4.24 \pm 0.02$ & 2.39 \\
\hline EVOH44-5\% & $6.29 \pm 0.15$ & --- & $5.11 \pm 0.03$ & 1.11 & $4.85 \pm 0.01$ & 1.78 \\
\hline EVOH44-10\% & $5.14 \pm 0.05$ & 1.01 & $4.07 \pm 0.05$ & 2.15 & $4.31 \pm 0.01$ & 2.32 \\
\hline
\end{tabular}

${ }^{a-c}$ Different letters in the same column indicate significant differences in antimicrobial effectiveness of different EVOH films (Turkey's adjusted analysis of variance, $P<0.05$ ). 
effective in liquid food. This is related to the amount of LAE released to the media and the release kinetics. These parameters depend on several factors, such as the water activity of the food and consequently the level of plasticization achieved by the films; and also the compatibility of the antimicrobial agent with the film and the food media. It must also be taken into account that in solid foods the morphological structure will also be affected by migration of the antimicrobial agent from the surface to the centre of the matrix.

Ultra-High-Temperature (UHT) processing normally involves a certain loss of heat-labile vitamins, which mostly have to be restored artificially after thermal treatment; degradation of organoleptic quality and loss of texture can also be produced [16]. In addition, the shelf-life of the products after opening is not more than 48 hours. Thus the chances of recontamination with these food-borne bacteria in the processing and packaging plant and after package opening and subsequent manipulation and storage at home are very high.

The results obtained in this study show that EVOH films incorporating LAE can contribute effectively to the development of active food packaging technologies. As an example, these films can be incorporated in a multilayer structure as the inner layer or coating in contact with the food. Thus active packaging could preserve all the food nutrients, without the incorporation of additives or the use of high thermal treatments. Moreover, it could increase the safety of the product after package opening and storage at home.

\subsection{In vitro availability analysis of $L A E$}

An in vitro digestion and subsequent HPLC analysis was carried out to evaluate LAE solubilised in the gastrointestinal tract. LAE was not detected in any of the digestion solutions (LOQLAE $=0.05 \mathrm{mg} / \mathrm{mL}$ ).
Bakal and Diaz (2005) demonstrated cleavage of the ethyl ester from LAE to form N-lauroyl-L-arginine (LAS) (LOQLAS $=0.02$ $\mathrm{mg} / \mathrm{mL}$ ), but this compound was also not detected in the chromatogram.

As already mentioned, LAE degrades to LAS and hydrolysis of it results in the production of arginine, which converts to ornithine and urea, following acid catabolism via the urea and citric acid cycles, resulting in carbon dioxide and urea, which are excreted in the expired air and in urine respectively [6]. The results demonstrate that these films have a great potential for the food safety industry without compromising human health. 


\section{CONCLUSIONS}

The results indicate that LAE is a powerful antimicrobial with a high activity against $L$. monocytogenes and E. coli. In this study, LAE was included at different concentrations (5 and 10\%) in films based on EVOH29 and EVOH44. The results demonstrate that these films can be applied to reduce native microflora and the growth of L. monocytogenes and E. coli in different food matrices (chicken stock and surimi sticks), increasing the safety of the products after package opening. Furthermore, it is interesting to note that after simulated gastrointestinal digestion LAE was not detected in any of the samples, demonstrating the safety of the antimicrobial agent. The application of the EVOH films incorporating LAE can contribute effectively to the development of active food packaging technologies. As an example, these films can be incorporated in a multilayer structure as the inner layer or coating in contact with the food. Thus active packaging could preserve all the food nutrients, without the incorporation of additives or the use of high thermal treatments. Moreover, it could increase the safety of the product after package opening and storage at home.

\section{Acknowledgements}

The authors acknowledge the financial support of the Spanish Ministry of Economy and Competitiveness, project AGL2012-39920-C03-01, and fellowship funding for V. M.-G. 


\section{REFERENCES}

[1] S.-Y. Sung, L.T. Sin, T.-T. Tee, S.-T. Bee, A.R. Rahmat, W.A.W.A. Rahman, A.-C. Tan, M. Vikhraman, Antimicrobial agents for food packaging applications, Trends in Food Science \& Technology, 33 (2013) 110-123.

[2] D. Kilcast, P. Subramaniam, The stability and shelf-life of food. Woodhead Publishing Cambridge, 2000.

[3] V. Muriel-Galet, G. Lopez-Carballo, R. Gavara, P. Hernandez-Munoz, Antimicrobial food packaging film based on the release of LAE from EVOH, International Journal of Food Microbiology, 157 (2012) 239-244.

[4] V. Muriel-Galet, G. López-Carballo, P. Hernández-Muñoz, R. Gavara, Characterization of ethylene-vinyl alcohol copolymer containing lauril arginate (LAE) as material for active antimicrobial food packaging, Food Packaging and Shelf life, 1 (2013) 10-17.

[5] G. Bakal, A. Diaz, The lowdown on lauric arginate, Food Quality, (2005) 60-61.

[6] D.R. Hawkins, X. Rocabayera, S. Ruckman, R. Segret, D. Shaw, Metabolism and pharmacokinetics of ethyl N-alpha-lauroyl-L-arginate hydrochloride in human volunteers, Food and Chemical Toxicology, 47 (2009) 2711-2715.

[7] V. Muriel Galet, G. López Carballo, R. Gavara, P. Hernandez Munoz, G. López Carballo, P. Hernández Muñoz, Antimicrobial food packaging film based on the release of LAE from EVOH, International Journal of Food Microbiology, 157 (2012) 239-244.

[8] M. Guo, T. Jin, L. Wang, O.J. Scullen, C. Sommers, Antimicrobial films and coatings for inactivation of Listeria innocua on ready-to-eat deli turkey meat, Food Control, 40 (2014) 64-70.

[9] L. Higueras, G. Lopez Carballo, P. Hernandez Munoz, R. Gavara, M. Rollini, G. López Carballo, P. Hernández Muñoz, Development of a novel antimicrobial film based on chitosan with LAE (ethyl-N)-dodecanoyl-l-arginate) and its application to fresh chicken, International Journal of Food Microbiology, 165 (2013) 339-345.
[10] P. Theinsathid, W. Visessanguan, J. Kruenate, Y. Kingcha, S. Keeratipibul, Antimicrobial activity of lauric arginate-coated polylactic acid films against Listeria monocytogenes and Salmonella typhimurium on cooked sliced ham, Journal of Food Science, 77 (2012) M142-149.

[11] E. Rodriguez, J. Seguer, X. Rocabayera, A. Manresa, Cellular effects of monohydrochloride of L-arginine, N-alpha-lauroyl ethylester (LAE) on exposure to Salmonella typhimurium and Staphylococcus aureus, Journal of Applied Microbiology, 96 (2004) 903-912.

[12] Sallam, K. Ibrahim, Antimicrobial and antioxidant effects of sodium acetate, sodium lactate, and sodium citrate in refrigerated sliced salmon, Food Control, 18 (2007) 566-575.

[13] P. Appendini, J.H. Hotchkiss, Review of antimicrobial food packaging, Innovative Food Science and Emerging Technologies, 3 (2002) 113-126.

[14] J.H. Han, Innovations in Food Packaging, (2013).

[15] M.R. Adams, M.O. Moss, Food Microbiology, The Royal Society of Chemistry Cambrigde, UK., 2008.

[16] P.J. Fellows, Food processing technology: Principe and practice, Third ed., 2009. 


\section{ANTIMICROBIAL PROPERTIES OF ETHYLENE VINYL ALCOHOL/EPSILON-POLYLYSINE FILMS AND THEIR APPLICATION IN SURIMI PRESERVATION}

Virginia Muriel-Galet', Gracia López-Carballo', Rafael Gavara ${ }^{\top}$ and Pilar Hernández-Muñoz*

Food and Bioprocess Technology, 2014, 1-12 


\section{ABSTRACT}

Polymer films based on ethylene vinyl copolymers (EVOH) containing a 29\% (EVOH29) and a $44 \%$ molar percentage of ethylene (EVOH44), and incorporating $\varepsilon$-polylysine (EPL) at 0, 1, 5 and 10\% were successfully made by casting. The optical properties and the amount of EPL released from the films to phosphate buffer at pH 7.5 were evaluated, films showing great transparency and those EVOH29 copolymer releasing a greater amount of EPL. The antimicrobial properties of the resulting films were tested in vitro against different foodborne microorganisms and in vivo in surimi sticks. With regard to the antimicrobial capacity tested in vitro in liquid medium at $37^{\circ} \mathrm{C}$ and $4{ }^{\circ} \mathrm{C}$ against Listeria monocytogenes and Escherichia coli over a period of $72 \mathrm{~h}$, films showed a considerable growth inhibitory effect against both pathogens, more notably against L. monocytogenes, and being EVOH29 more effective than EVOH44 films. At $37^{\circ} \mathrm{C}$ total growth inhibition was observed for EVOH29 films incorporating 10\% EPL against both microorganisms whereas the copolymer EVOH44 did show total inhibition against L. monocytogenes and the growth of E. coli was reduced by $6.64 \log$ units. At $4{ }^{\circ} \mathrm{C}$ no film was able to inhibit completely bacterial growth. Scanning electron microscopy micrographs showed corrugated cell surfaces with blisters and bubbles, and collapse of the cells appearing shorter and more compact after treatment with EPL. Finally, the films were successfully used to increase the shelf life of surimi sticks. The results show the films developed have great potential for active food packaging applications.

Keywords: EVOH, epsilon-polylysine; antimicrobial polymer films; L. monocytogenes; E. coli 


\section{INTRODUCTION}

Ready-to-eat products with an extended shelf life, stored at refrigeration temperatures $\left(4^{\circ} \mathrm{C}\right)$ and consumed without further cooking have been implicated in various outbreaks of microbial food-borne illness. Listeria monocytogenes and Escherichia coli have been implicated in many outbreaks, most commonly due to post-processing contamination [1, 2].

Listeriosis is a food-borne illness that affects susceptible populations, such as the young, the elderly, pregnant women and immunocompromised individuals (YOPIs). L. monocytogenes is considered a pathogen of major concern. It has a long incubation period, which makes it difficult to identify the food that is contaminated with L. monocytogenes and causes illness [3]. E. coli is found in a wide variety of foods, causing food-borne disease outbreaks [4, 5]. A great number of cases can be severe and they are sometimes fatal.

Imitation crab meat (surimi) is a paste prepared from mechanically deboned, washed (bleached) and stabilized flesh of fish [6]. Surimi is one of the most promising approaches to obtain value-added food products from low-cost fishery products [7]. Surimi is used in the preparation of cooked ready-to-eat products which are sensitive to microbial contamination with diverse Gram positive and Gram negative bacteria after processing, e.g. L. monocytogenes [8]. This microorganism is a serious threat to food safety in processing plants, being a very ubiquitous bacterium that can grow in many chilled food products. Proper refrigeration temperature below $4^{\circ} \mathrm{C}$, handling, preparation and service under Good Manufacturing Practices (GMP) are strategies that can prevent the cross-contamination of surimi products $[9,10]$.
The increase in food-borne illness outbreaks has intensified research on antimicrobial packaging technologies [11], with a particular interest in the use of natural antimicrobial agents, including essential oils and their components, organic acids, enzymes, peptides, etc. Epsilon-polylysine (EPL) is a natural cationic linear homopolymer compound of 25-35 residues of L-lysine connected between the $\varepsilon$-amino and a-carboxyl groups $[12,13]$. It is produced from aerobic fermentation by Streptomyces albulus, a non-pathogenic microorganism [14]. EPL is characterized as being edible, water soluble, stable at high temperatures and of low environmental impact because of its biodegradability. The antimicrobial activity of EPL depends on electrostatic interaction with the cell surface of microorganisms, leading to distortion of the outer membrane and producing abnormal distribution of the cytoplasm [13]. EPL has an isoelectric point of 9.0, and the optimum $\mathrm{pH}$ range to exert its antimicrobial activity is between 5 and 8. EPL is nontoxic to humans and has been approved as a food additive in Japan at a concentration of 1000-5000 ppm for sliced fish or fish sushi and at a concentration of 10-500 ppm for the preservation of rice, soup and vegetables $[15,16]$. EPL has been classified as GRAS (Generally Recognized as Safe) by the Food and Drug Administration (FDA) [17]. In recent years, EPL has been used in a wide range of industrial applications, as a food preservative [18, 19], emulsifying agent [20], etc. Information regarding the antimicrobial activity of EPL when it is incorporated into a film matrix is limited, finding studies with edible coatings [18, 21], however, no studies have been found in the bibliography regarding the development of antimicrobial films by incorporating EPL in conventional polymer matrices 
used in food packaging.

Ethylene-vinyl alcohol (EVOH) copolymers are approved for food contact applications and have been used as matrices for the development of active packaging systems [2, 22-26]. Because of their hydrophilic nature, EVOH films have a great potential to be used as carriers and release matrices of bioactive agents. These polymers can protect the agent during storage in a dry environment and trigger their activity on exposure to a humid environment, in this case created by the packaged food product [27].
In this context, the present study intends to show the potential of EVOH copolymers to develop antimicrobial films for food packaging applications incorporating the antimicrobial compound EPL in EVOH films containing a 29 and a 44\% molar percentage of ethylene. The ability of the films to inhibit the growth of L. monocytogenes and E. coli was evaluated in vitro. Finally, the effectiveness of the films was tested in a real food, surimi sticks. This product is an ideal medium for bacterial growth because it has high water and nutrient contents and limited shelf life.

\section{MATERIALS AND METHODS}

\subsection{Materials}

Ethylene vinyl alcohol copolymer (EVOH) possessing a 29 and a $44 \%$ ethylene molar content was kindly provided by The Nippon Synthetic Chemical Company (Osaka, Japan); 1-propanol was purchased from Sigma (Madrid, Spain). EPL, from Chisso Corporation (Yokohama, Japan), was kindly provided by Goddard Research Group (Amherst, USA). Imitation crab meat (surimi) was purchased from a local market, labelled as preservative-free and containing $2.5 \mathrm{~g}$ of total fat, $12.9 \mathrm{~g}$ of total carbohydrate, and $8.4 \mathrm{~g}$ of protein.

\subsection{Film Preparation}

EVOH films were prepared as described in a previous work [22]. Briefly, EPL was dissolved in distilled water at 1, 5 and 10\% (g/100 g dry polymer). EVOH29 was dissolved in a 1-propanol:EPL water mixture at $80{ }^{\circ} \mathrm{C}$ and EVOH44 in a 2:1 (v:v) 1-propanol:EPL water mixture at the same temperature. The solution was stirred for 30 min using a magnetic stirrer. After that time, $5 \mathrm{~mL}$ of each film- forming solution was extended over a glass plate using an extension bar, and placed in a drying tunnel equipped with a $2500 \mathrm{~W}$ heat source for 10 min until it was completely dry. Films prepared without EPL were used as controls. Film thickness was measured using a Mitutoyo micrometer (Osaka, Japan) and had an average value of $15 \pm 2 \mu \mathrm{m}$. Finally, the films were stored in glass desiccators containing silica gel at $22^{\circ} \mathrm{C}$ prior to use.

\subsection{Optical properties}

Film colour was measured with a Konica Minolta CM-3500d spectrophotometer (Konica Minolta Sensing Inc., Osaka, Japan) set to D65 illuminant $/ 10^{\circ}$ observer angle. The film specimen was placed on the surface of a standard white plate. The instrument's software, SpectraMagic NX, was used to acquire the colour data and to display them in the CIELAB colour space.

The parameters $L^{*}$ (black (0) to white (100)), $a^{*}$ (green $(-)$ to red $\left.(+)\right)$ and $b^{*}$ (blue (-) to yellow $(+))$ were obtained and the polar coordinates, the chroma $C^{*}$ and the hue angle 
$h^{\circ}$ were calculated. Eight measurements of each sample were taken, and three samples of each film were evaluated. All the samples were selected with the same thickness to reduce the effect of thickness on the colour parameters.

\subsection{Quantification of EPL migration from EVOH films}

The amount of EPL capable of migrating out of the polymer matrix was quantified using the bicinchoninic acid assay (BCA). A sample of $0.25 \mathrm{~g}$ of each film (control, and incorporating 1, 5 and 10\% of EPL) was immersed in $10 \mathrm{~mL}$ of $\mathrm{pH} 7.5$ phosphate buffer for 24 hours at $37^{\circ} \mathrm{C}$. After that time, $100 \mu \mathrm{L}$ of each sample was put in contact with the working reagent. The absorbance was measured at $562 \mathrm{~nm}[28,29]$ using a POLARstar Omega multi-detection microplate reader (Biogen Cientifica S.L., Madrid, Spain). A standard curve of bovine serum albumin was used to calculate protein mass per film sample area.

\subsection{Antimicrobial tests}

\subsubsection{Strains}

Gram positive bacterium Listeria monocytogenes CECT 934 (ATTCC 19114) and Gram negative bacterium Escherichia coli CECT 434 (ATCC 25922) were selected because of their relevance to imitation crabmeat (surimi). Strains were obtained from the Spanish Type Culture Collection (CECT Valencia, Spain) and stored in Tryptone Soy Broth (TSB), purchased from Scharlab (Barcelona, Spain), with $20 \%$ glycerol at $-80{ }^{\circ} \mathrm{C}$ until needed. For experimental use, the stock cultures were maintained by regular subculture on slants of Tryptone Soy Agar (TSA) from Scharlab (Barcelona, Spain) at $4{ }^{\circ} \mathrm{C}$ and transferred monthly. Before each experiment a loopful of each strain was transferred to $10 \mathrm{~mL}$ of TSB and incubated at 37 ${ }^{\circ} \mathrm{C}$ for $18 \mathrm{~h}$ to obtain early-stationary phase cells.

\subsubsection{Antimicrobial activity of EPL against L. monocytogenes and E. coli}

The antimicrobial activity of EPL was tested in sterile TSB to study the minimum inhibitory concentration (MIC) and the minimum bactericidal concentration (MBC) against L. monocytogenes and E. coli. To do so, serial dilutions of 1000 ppm of EPL in peptone water were made. Previously, 100 $\mu \mathrm{L}$ of cell cultures of each microorganism in stationary phase, with an optical density of 0.9 at $595 \mathrm{~nm}$, was diluted in $10 \mathrm{~mL}$ of TSB and incubated at $37^{\circ} \mathrm{C}$ until exponential phase, corresponding to an optical density of 0.2 at $595 \mathrm{~nm}\left(10^{5} \mathrm{CFU} / \mathrm{mL}\right)$. Optical density was measured with a UV-Vis spectrophotometer (Agilent 8453 Spectroscopy System) using TSB as blank. $100 \mu \mathrm{L}$ of each microorganism in exponential phase was inoculated in each test tube with $100 \mu \mathrm{L}$ of EPL solution at concentrations ranging between 10 and $150 \mu \mathrm{g} / \mathrm{mL}$. Tubes with $100 \mu \mathrm{L}$ of peptone water were used as control. Turbidity at $595 \mathrm{~nm}$ was determined after 24 and 72h [30]. The lowest EPL concentration that inhibited the pathogen microorganisms was recorded as the MIC. The MBC was the lowest concentration at which bacteria failed to grow in TSB and were not culturable after spreading $100 \mu \mathrm{L}$ onto $15 \mathrm{~mL}$ of culture medium TSA. Tests were performed in triplicate.

\subsubsection{Antimicrobial activity of EVOH films containing EPL against L. monocytogenes and E. coli}

Antimicrobial activity of EVOH films with EPL was tested in liquid media at $37^{\circ} \mathrm{C}$. This temperature was chosen because it is the optimal growth temperature and it is a standard method to evaluate the activity of antimicrobial films. For this purpose, 0.25 $\mathrm{g}$ of $\mathrm{EVOH}$ films cut into pieces measuring $1.5 \mathrm{~cm}^{2}$ (EVOH29 and EVOH44), without and with 1, 5 and 10\% EPL, was added to a glass tube containing $10 \mathrm{~mL}$ of TSB. Then $100 \mu \mathrm{L}$ of microorganism in exponential 
phase was transferred to the samples and incubated at $37^{\circ} \mathrm{C}$ for $24 \mathrm{~h}$. Depending on the turbidity of the tubes, serial dilutions with peptone water were made and plated in Petri dishes with $15 \mathrm{~mL}$ of TSA culture medium. Colonies were counted after incubation at $37^{\circ} \mathrm{C}$ for $24 \mathrm{~h}$.

\subsubsection{Scanning electron microscopy obser- vations}

After the microorganisms had been in contact with EVOH films at $37^{\circ} \mathrm{C}$ for $24 \mathrm{~h}$ as described above, the samples were centrifuged and resuspended twice in saline solution $(0.8 \% \mathrm{NaCl})$. The suspension was filtered on a $0.2 \mathrm{~mm}$ Nuclepore Track-Etch Membrane (Whatman, UK) and the membranes were dehydrated in graded alcohols (30\%, 50\%, 70\%, 90\% and 100\%). SEM observation of L. monocytogenes and E. coli was carried out, working at 5-10 kV (HITACHI S 4100).

\subsubsection{Antimicrobial activity of EVOH films containing EPL over time}

Next, the effect of EVOH with EPL films on the growth of L. monocytogenes and $E$. coli over time was studied. Bacterial growth experiments were performed at two temperatures, $37^{\circ} \mathrm{C}$ and $4{ }^{\circ} \mathrm{C}$, and they lasted 72 hours. For this purpose, $100 \mu \mathrm{L}$ of exponential phase microorganism was inoculated into tubes with $10 \mathrm{~mL}$ of TSB. $0.25 \mathrm{~g}$ of EVOH films cut into pieces measuring 1.5 $\mathrm{cm}^{2}$ (EVOH29 and EVOH44), without and with 1, 5, and 10\% EPL, was added to each tube and incubated at the corresponding temperature. Aliquots containing $100 \mu \mathrm{L}$ were removed from the solution at 0, 1, 3, 6, 24, 48 and 72 hours and serial dilutions with peptone water were made and plated in Petri dishes with $15 \mathrm{~mL}$ of TSA culture medium. Colonies were counted after incubation at $37{ }^{\circ} \mathrm{C}$ for $24 \mathrm{~h}$. Experiments were performed in triplicate.

\subsubsection{Antimicrobial activity of EVOH films incorporating EPL in surimi microbiota}

Refrigerated surimi sticks were purchased in a local market. Individual pieces (ca. $25 \mathrm{~g}$ ) were wrapped with EVOH29 and EVOH44 films containing 10\% of EPL. Samples without film, and samples wrapped with EVOH29 and EVOH44 films without EPL were prepared as controls. All the surfaces of the food were in contact with the films. Samples were stored at $4{ }^{\circ} \mathrm{C}$ for 6 days.

The effect on the surimi microbiota of being covered with film was evaluated on days 1, 3 and 6. For this purpose, at appropriate times, surimi samples were transferred aseptically in a sterile stomacher bag, diluted with $25 \mathrm{~mL}$ of peptone water (Scharlab, Barcelona, Spain) for 3 min using a Stomacher (IUL S.L., Barcelona). Serial dilutions in the same saline solution were plated on specific media (Scharlab, Barcelona, Spain) under the following culture conditions: a) Violet Red Bile Glucose agar (VRBG) for total enterobacteria, incubated at $37^{\circ} \mathrm{C}$ for 48 h; b) Man, Rogosa and Sharpe agar (MRS) for lactic acid bacteria, incubated at $25^{\circ} \mathrm{C}$ for 5 days; c) Nutrient Agar (NA) for total aerobic bacteria, incubated at $37{ }^{\circ} \mathrm{C}$ for 48 h; d) Nutrient Agar (NA) for total aerobic psychrotrophic bacteria, incubated at $10^{\circ} \mathrm{C}$ for 10 days; e) Plate Count Agar (PCA) for total aerobic count, incubated at $30{ }^{\circ} \mathrm{C}$ for 48 h; f) King B agar for Pseudomonas, incubated at $30^{\circ} \mathrm{C}$ for $48 \mathrm{~h}$. The counts were performed in triplicate.

\subsubsection{Antimicrobial activity of EVOH films incorporating EPL on surimi inoculated with L. monocytogenes and E. coli}

For this study, surimi sticks were inoculated with a diluted overnight culture (100 $\mu \mathrm{L} ; 105 \mathrm{CFU} / \mathrm{mL}$ ) of L. monocytogenes and E. coli. The inoculums were separately dispersed on the food surface with a sterile pipette. The subsequent procedure was similar to that described in the previous 
section. The antimicrobial activity of the films against inoculated microorganisms was evaluated on days 1, 3 and 6, as mentioned above. For this purpose, serial dilutions were made and plated on selective media: Palcam Listeria Selective Agar for L. monocytogenes (Scharlab, Barcelona, Spain) and Brilliant Green agar for E. coli. Colonies were counted after incubation at $37^{\circ} \mathrm{C}$ for $24 \mathrm{~h}$. Samples were analysed in triplicate.

\subsection{Statistical analysis}

One-way analyses of variance were carried out using the SPSS®19 computer program (SPSS Inc., Chicago, IL, USA). Differences in pairs of mean values were evaluated by the Tukey test for a confidence interval of 95\%. Data are represented as mean \pm standard deviation.

\section{RESULTS AND DISCUSSION}

In this work, EPL was successfully incorporated in EVOH films (EVOH29 and EVOH44) at 1, 5 and 10\% and the films, produced by casting, were transparent and without discontinuities, presenting a thickness of approximately $15 \pm 2 \mu \mathrm{m}$.

\subsection{Optical properties}

Colour coordinates $L^{*}, a^{*}, b^{*}$, chroma $\left(C^{*}\right)$ and hue $\left(h^{\circ}\right)$ of films made from EVOH29 and EVOH44 without and with 1, 5 and $10 \%$ of EPL are given in Table 1. Incorporation of the antimicrobial agent did not affect the luminosity of either of the copolymer films, since in all the samples the $L^{*}$ values are similar to those obtained for the control (Table 1), without significant differences. Colour coordinates $a^{*}$ and $b^{*}$ presented values close to -1 and 1 respectively for both films, EVOH29 and EVOH44. The addition of EPL increased the absolute value of both coordinates when EPL was added at the higher concentration, with significant differences appearing between samples and control. Colour intensity given by the chroma $\left(C^{*}\right)$ parameter increased with the concentration of EPL but films maintained their original light yellowgreen tone given by the hue $\left(h^{\circ}\right)$ parameter. Significant differences were only found in C* for films containing 10\% EPL were compared with control films.

Table 1. Colour parameters of EVOH29 and EVOH44, without and with 1, 5 and 10\% of EPL.

\begin{tabular}{|c|c|c|c|c|c|}
\hline EVOH29 & $\mathrm{L}^{*}$ & $a^{*}$ & $b^{*}$ & $C^{*}$ & $\mathrm{~h}^{\circ}$ \\
\hline CONTROL & $90.27 \pm 0.18^{a}$ & $-0.86 \pm 0.02^{a}$ & $1.09 \pm 0.04^{a}$ & $1.39 \pm 0.02^{a}$ & $128.22 \pm 1.65^{a}$ \\
\hline 1\% EPL & $89.43 \pm 0.65^{a}$ & $-0.89 \pm 0.02^{a}$ & $1.13 \pm 0.10^{a}$ & $1.44 \pm 0.08^{a}$ & $128.41 \pm 2.64^{a}$ \\
\hline $5 \%$ EPL & $89.40 \pm 0.70^{a}$ & $-0.93 \pm 0.04^{a}$ & $1.13 \pm 0.08^{a}$ & $1.47 \pm 0.04^{a}$ & $129.49 \pm 3.04^{a}$ \\
\hline $10 \%$ EPL & $89.84 \pm 0.43^{a}$ & $-0.97 \pm 0.02^{b}$ & $1.30 \pm 0.04^{b}$ & $1.62 \pm 0.02^{b}$ & $129.82 \pm 1.53^{a}$ \\
\hline EVOH44 & $\mathrm{L}^{*}$ & $a^{*}$ & $b^{*}$ & $C^{*}$ & $h^{\circ}$ \\
\hline ONTROL & $89.82 \pm 0.97^{a}$ & $-0.88 \pm 0.05^{a}$ & $1.02 \pm 0.12^{a}$ & $1.35 \pm 0.07^{a}$ & $129.12 \pm 4.34^{a}$ \\
\hline $1 \%$ EPL & $89.98 \pm 0.53^{a}$ & $-0.86 \pm 0.06^{a}$ & $1.07 \pm 0.08^{a}$ & $1.38 \pm 0.08^{a}$ & $128.86 \pm 2.59^{a}$ \\
\hline $5 \%$ EPL & $89.80 \pm 0.67^{a}$ & $-0.89 \pm 0.04^{a}$ & $1.16 \pm 0.08^{b}$ & $1.47 \pm 0.05^{b}$ & $127.42 \pm 2.83^{a}$ \\
\hline $10 \%$ EPL & $90.21 \pm 0.66^{a}$ & $-0.98 \pm 0.06^{b}$ & $1.24 \pm 0.09^{b}$ & $1.57 \pm 0.10^{b}$ & $127.55 \pm 0.95^{a}$ \\
\hline
\end{tabular}


Table 2. EPL migrated from EVOH films to phosphate buffer $\mathrm{pH} 7.5$ at $37^{\circ} \mathrm{C}$ after 24 hours

EPL in EVOH (\%) From EVOH29 ( $\mu \mathrm{g} / \mathrm{mL})$ Migration (\%) From EVOH44 ( $\mathrm{g} / \mathrm{mL})$ Migration (\%)

\begin{tabular}{rrrrc}
\hline 1\% EPL & $47.43 \pm 0.02^{\mathrm{a}}$ & 18.97 & $42.87 \pm 0.01^{\mathrm{a}}$ & 17.15 \\
\hline 5\% EPL & $68.19 \pm 0.02^{\mathrm{b}}$ & 5.45 & $58.82 \pm 0.01^{\mathrm{b}}$ & 4.71 \\
\hline $10 \% \mathrm{EPL}$ & $95.90 \pm 0.03^{\mathrm{c}}$ & 3.84 & $71.46 \pm 0.03^{\mathrm{c}}$ & 2.86 \\
\hline
\end{tabular}

${ }^{a^{-c}}$ Different letters in the same column indicate significant differences among the values of EPL migrated to the liquid medium (Turkey's adjusted analysis of variance, $P<0.05$ ).

\subsection{Quantification of EPL migration from} EVOH films

The amount of protein that had migrated after $24 \mathrm{~h}$ at $37^{\circ} \mathrm{C}$ in $\mathrm{pH} 7.5$ phosphate buffer was determined with the BCA assay. Table 2 shows the results obtained for EVOH29 and EVOH44 films incorporating 1, 5 and 10\% EPL. The value of the protein released into the phosphate buffer increased with the concentration of EPL in the films, being $47.43 \mu \mathrm{g} / \mathrm{mL}$ for $1 \%$ and $95.90 \mu \mathrm{g} / \mathrm{mL}$ for $10 \%$ with EVOH29. For EVOH44, the amount that migrated was $42.87 \mu \mathrm{g} / \mathrm{mL}$ for films with 1\% EPL and $71.46 \mu \mathrm{g} / \mathrm{mL}$ for films with 10\% EPL. It can be observed that films with a higher percentage of ethylene retained a greater amount of EPL. This behaviour has been observed previously for the antimicrobial LAE [31]. The lower swelling achieved for EVOH44 films in liquid media could explain the results obtained.

\subsection{Antimicrobial activity of EPL against L. monocytogenes and E. coli}

The antimicrobial activity of EPL was tested against L. monocytogenes and E. coli. The growth of L. monocytogenes and E. coli was inhibited by EPL at concentrations in TSB of 23 and $40 \mathrm{ppm}$, respectively. In another study, a lower MIC value was reported for L. monocytogenes [32], but according to various authors EPL inhibits the growth of both Gram positive and Gram negative bacteria and the minimum inhibitory concentration is below 100 ppm [13, 14]. Differences in methodology, media composition and bacterial strains may be responsible for the different values. The MBC values obtained were 70 and $90 \mathrm{ppm}$ for L. monocytogenes and E. coli, respectively. The antimicrobial effect of EPL is attributed to electrostatic absorption onto the cell surface of the microorganism, where it interacts with the bacterial membranes [33]. The difference in the MIC values between the Gram positive and Gram negative bacteria might derive from different cell surface conditions of the bacteria tested. Gram negative microorganisms have an increased defence system and are less susceptible to antibacterial action than Gram positive microorganisms. They have an outer membrane surrounding the cell wall that restricts the diffusion of compounds [34].

\subsection{Antimicrobial activity of EVOH films containing EPL against L. monocytogenes and E. coli}

The antimicrobial activity of the EVOH films was tested against L. monocytogenes and E. coli.

Tables 3 and 4 present the results for EVOH29 and EVOH44 films, respectively. The EVOH29 films with 1\% EPL produced a $4.09 \mathrm{log}$ reduction in the growth of L. monocytogenes and a $2.74 \log$ reduction for $E$. coli. Films with 5\% EPL produced a reduction of 6.09 log against L. monocytogenes and $5.58 \mathrm{log}$ for E. coli, and films with 10\% EPL produced total inhibition against both microorganisms tested. 
Table 3. Antimicrobial effectiveness of EVOH29 films against L. monocytogenes and E. coli at $37^{\circ} \mathrm{C}$ expressed as logarithm of colony forming units per $\mathrm{mL}(\mathrm{Log}(\mathrm{CFU} / \mathrm{mL}))$ and logarithm reduction value (LRV).

L. monocytogenes

\begin{tabular}{rcccc}
\hline & Log $(\mathrm{CFU} / \mathrm{mL})$ & LRV & Log $(\mathrm{CFU} / \mathrm{mL})$ & LRV \\
\hline CONTROL & $8.49 \pm 0.08^{\mathrm{c}}$ & & $9.08 \pm 0.02^{\mathrm{c}}$ & \\
\hline EVOH29 1\% EPL & $4.40 \pm 0.12^{\mathrm{b}}$ & 4.09 & $6.34 \pm 0.12^{\mathrm{b}}$ & 2.74 \\
\hline EVOH29 5\% EPL & $2.40 \pm 0.09^{\mathrm{a}}$ & 6.09 & $3.50 \pm 0.12^{\mathrm{a}}$ & 5.58 \\
\hline EVOH29 10\% EPL & Total inhibition & 8.49 & Total inhibition & 8.49 \\
\hline
\end{tabular}

${ }^{a-c}$ Different letters in the same column indicate significant differences in antimicrobial effectiveness of different EVOH29 films (Turkey's adjusted analysis of variance, $P<0.05$ ).

As can be seen in Table 4 (EVOH44 films), the viable counts for all microorganisms decreased with 1\% EPL, being 1.39 for L. monocytogenes and 0.52 for E. coli. Films containing 5\% EPL caused a growth reduction of 4.97 log against L. monocytogenes and 3.94 for E. coli, and EVOH44 films with 10\% EPL produced total inhibition only against L. monocytogenes and produced a $6.64 \log$ reduction in the growth of E. coli.

The results show that the antimicrobial activity was greater for EVOH29 than for EVOH44 films, and E. coli appears to be less susceptible to the antimicrobial effect of EPL. This lower antimicrobial effect of EVOH44 films was expected; as noted in the migration assay of EPL carried out with BCA, the amount of EPL that migrated from EVOH44 films was always lower than the amount that migrated from EVOH29 films.

\subsection{Scanning electron microscopy observa- tions}

SEM was performed on bacteria exposed to EVOH29 and EVOH44 films with 10\% EPL, to study the morphological changes resulting in the membrane structure. The micrographs show that bacteria exposed to the antimicrobial films displayed considerable morphological alterations in comparison with control bacteria. Figs. $1 \mathrm{~A}$ and $1 \mathrm{C}$ show micrographs of control L. monocytogenes and E. coli, respectively, with bacteria presenting a smooth surface and characteristic rod shape. Figs. $1 \mathrm{~B}$ and $1 \mathrm{D}$ show bacteria that have been exposed to the antimicrobial films, and it can be observed that the bacteria are seriously damaged, presenting an irregular rough surface with blisters and bubbles and the collapse of the bacteria compared with the control. In the case of L. monocytogenes the alterations are more obvious.

Table 4. Antimicrobial effectiveness of EVOH44 films against L. monocytogenes and E. coli at $37^{\circ} \mathrm{C}$ expressed as logarithm of colony forming units ( $\log (\mathrm{CFU} / \mathrm{mL}))$ and log reduction value (LRV).

\section{L. monocytogenes}

\begin{tabular}{rcccc}
\hline & $\log (\mathrm{CFU} / \mathrm{mL})$ & LRV & $\log (\mathrm{CFU} / \mathrm{mL})$ & LRV \\
\hline CONTROL & $8.15 \pm 0.06^{\mathrm{c}}$ & & $8.86 \pm 0.07^{\mathrm{c}}$ & \\
\hline EVOH44 1\% EPL & $6.76 \pm 0.03^{\mathrm{b}}$ & 1.39 & $8.34 \pm 0.15^{\mathrm{c}}$ & 0.52 \\
\hline EVOH44 5\% EPL & $3.18 \pm 0.01^{\mathrm{a}}$ & 4.97 & $4.92 \pm 0.09^{\mathrm{b}}$ & 3.94 \\
\hline EVOH44 10\% EPL & Total inhibition & 8.15 & $2.22 \pm 0.19^{\mathrm{a}}$ & 6.64 \\
\hline
\end{tabular}

${ }^{a-c}$ Different letters in the same column indicate significant differences in antimicrobial effectiveness of different EVOH44 films (Turkey's adjusted analysis of variance, $P<0.05$ ). 
The images reveal that EPL leads to dramatic changes in the cell membrane. This hypothesis is consistent with the results obtained by Shima et al. (1984), which show that the mechanism of action of EPL on bacterial growth is the electrostatic adsorption onto the cell surface of microorganisms, increasing the membrane permeability and causing an abnormal distribution of cytoplasm.

\subsection{Antimicrobial activity of EVOH films containing EPL over time}

\subsubsection{Bacterial growth studies at $37^{\circ} \mathrm{C}$}

Fig. 2 shows the growth curves at $37^{\circ} \mathrm{C}$ of L. monocytogenes and E. coli exposed to EVOH29 films containing 1, 5 and 10\% EPL for a period of 72 hours. Fig. 3 shows the results obtained with EVOH44. As can be
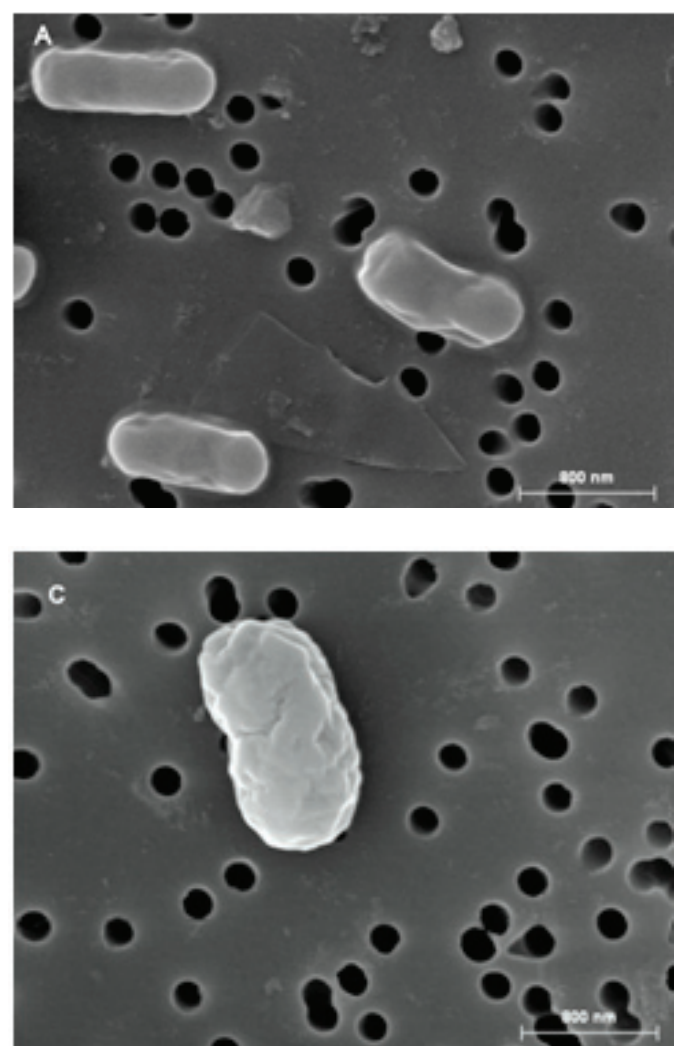

seen in both figures, in the absence of antimicrobial films the bacteria grow to values of $9 \log$ at $37^{\circ} \mathrm{C}$; owing to temperature conditions and presence of nutrients in the liquid media, the bacteria exhibited optimal growth. Fig. 2A shows that the antimicrobial activity of EVOH29 films against L. monocytogenes increased with the concentration of EPL in the film. Films with 1\% EPL presented 3 reductions after 3 hours in contact with the bacteria, maintaining these values throughout the 72-hour period studied. EVOH29 films with 5 and 10\% EPL produced a more rapid decrease in bacterial growth at short times. After 1 hour these films caused reductions of 1.84 and 2.89 log compared with the control, and the maximum inhibition degree was reached after 6 hours. Films containing 5\% EPL produced a 6 log reduction and films with 10\% EPL caused total inhibition, and


Figure 1. Scanning electron micrographs of L. monocytogenes cell A) CONTROL and B) 10\% EPL. E. coli cell C) CONTROL and D) 10\% EPL. 
these values remained constant until the end of the experiment.

Antimicrobial activity of EVOH29 films against E. coli over a 72-hour exposure period is given in Fig. 2B; for films with $1 \%$ EPL the inhibition was 2.5 log after 6 hours and this value was maintained until the end of the experiment. After 1 hour, films with 5 and 10\% EPL produced reductions of $1.5 \mathrm{log}$ and $2.5 \mathrm{log}$, respectively, in comparison with the control. Films with 5 and 10\% EPL also reached the maximum inhibition degree after 6 hours of being in contact with the bacteria, and this value remained constant, with 3 log reductions for films with 5\% EPL and total inhibition for films with 10\% EPL.

Figs. 3A and 3B show the results obtained when working with EVOH44 instead of EVOH29 against L. monocytogenes and E. coli, respectively. EVOH44 films with 1\% EPL showed a 2 log reduction after 3 hours in contact with L. monocytogenes, maintaining these values throughout the period of time studied. Films with 5 and 10\% EPL reached the maximum inhibition degree after 6 hours, producing a 5 log reduction when 5\% EPL was incorporated and total inhibition with 10\% EPL. These results were maintained until the end of the experiment.

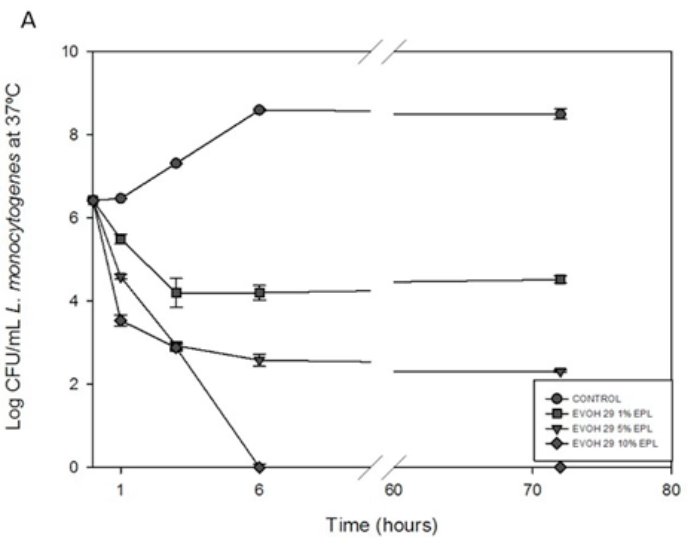

Fig. 3B shows the growth curve of EVOH44 films against E. coli. No inhibition was observed with 1\% EPL. The maximum inhibition degree achieved for films with 5\% EPL was 4 log reductions, and films with 10\% EPL produced a reduction of $7 \mathrm{log}$. As mentioned above, the antimicrobial activity against Gram negative bacteria was lower and total inhibition was only observed with EVOH29 films incorporating 10\% EPL. EVOH29 proved to be more effective than EVOH44, releasing EPL to the media and then inhibiting bacterial growth.

\subsubsection{Bacteria growth studies at $4^{\circ} \mathrm{C}$}

Bacterial growth studies were also carried out at a temperature of $4{ }^{\circ} \mathrm{C}$ to test the effectiveness of the films at refrigeration temperatures in order to simulate storage conditions in the consumer's refrigerator. The antimicrobial activity of EVOH29 and EVOH44 films against L. monocytogenes and $E$. coli at $4^{\circ} \mathrm{C}$ overtime is shown in Figs. 4 and 5 for each copolymer.

L. monocytogenes is a psychrotrophic pathogen whose ability to survive and multiply at low temperatures is demonstrated in Figs. 4A and 5A. As can be observed, bacteria reached values of $7.5 \mathrm{log}$ after 72 hours of exposure to control films in liquid media.

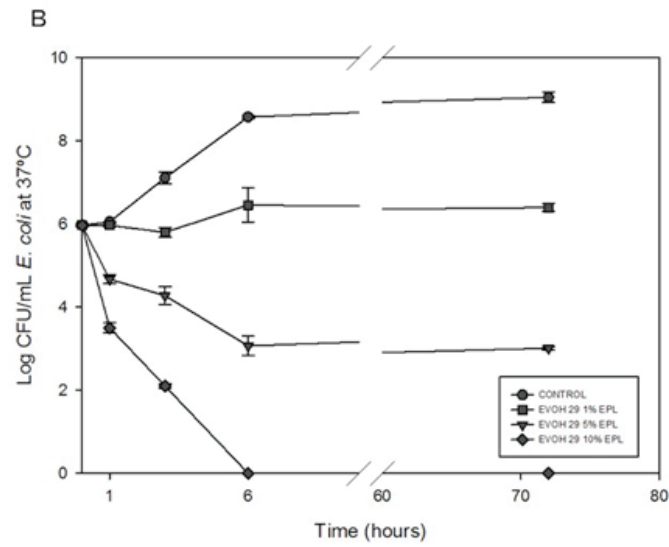

Figure 2. Growth control study with EVOH29 control, 1, 5 and 10\% EPL. A) L. monocytogenes at 37 ${ }^{\circ} \mathrm{C}$ and B) E.coli at $37^{\circ} \mathrm{C}$. 



Figure 3. Growth control study with EVOH44 control, 1, 5 and 10\% EPL. A) L. monocytogenes at 37 ${ }^{\circ} \mathrm{C}$ and B) E. coli at $37^{\circ} \mathrm{C}$.

In contrast, refrigeration temperature significantly reduced the growth of E. coli. As can be seen in Figs. 4B and 5B, the control sample maintained bacterial counts around 6 log throughout the experiment. Films with 1\% EPL showed a reduction of ca. 2 log and 1.5 log for EVOH29 and EVOH44, respectively, against L. monocytogenes compared to the control. However, no inhibition was observed against E. coli, which may be due to slow release of EPL to the medium, being below the minimum inhibitory concentration value. Considering that the amount of protein migrated from films with $1 \%$ EPL in phosphate buffer at $37^{\circ} \mathrm{C}$ for $24 \mathrm{~h}$ is $47.43 \mu \mathrm{g} / \mathrm{mL}$ and $42.87 \mu \mathrm{g} / \mathrm{mL}$ for EVOH29 and EVOH44, respectively,

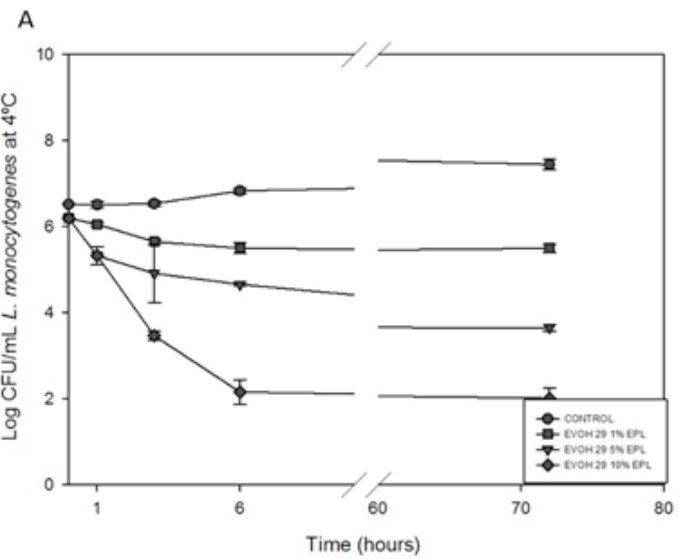

and taking into account that in the current experiment the release temperature is $4{ }^{\circ} \mathrm{C}$, it can be expected that the release of the antimicrobial would occur more slowly and the films would have less effectiveness. Furthermore, films incorporating a greater amount of EPL were not able to inhibit completely the growth of all the microorganisms tested. Thus, EVOH29 and EVOH44 films with 10\% EPL gave similar reduction values against $L$. monocytogenes and E. coli: reductions of $5.5 \mathrm{log}$ and $4.8 \mathrm{log}$ against L. monocytogenes were observed with EVOH29 and EVOH44, respectively, and $4 \log$ and $3.5 \log$ against E. coli.

It can be concluded from this experiment

B



Figure 4. Growth control study with EVOH29 control, 1, 5 and 10\% EPL. A) L. monocytogenes at 4 ${ }^{\circ} \mathrm{C}$ and B) E. coli at $4{ }^{\circ} \mathrm{C}$. 
A

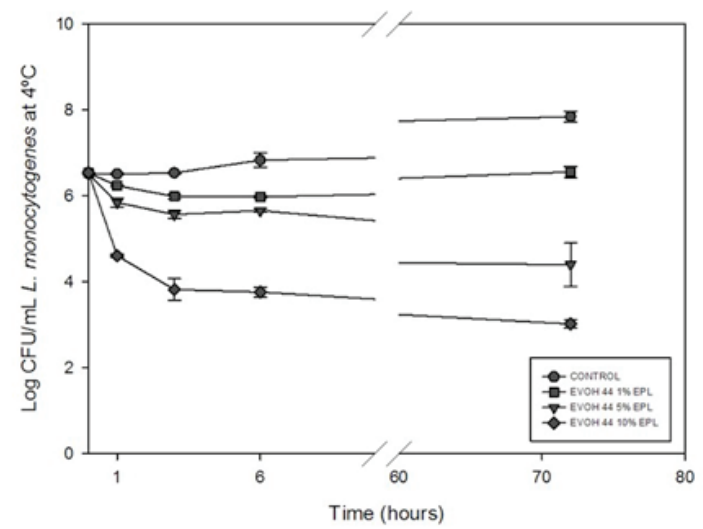

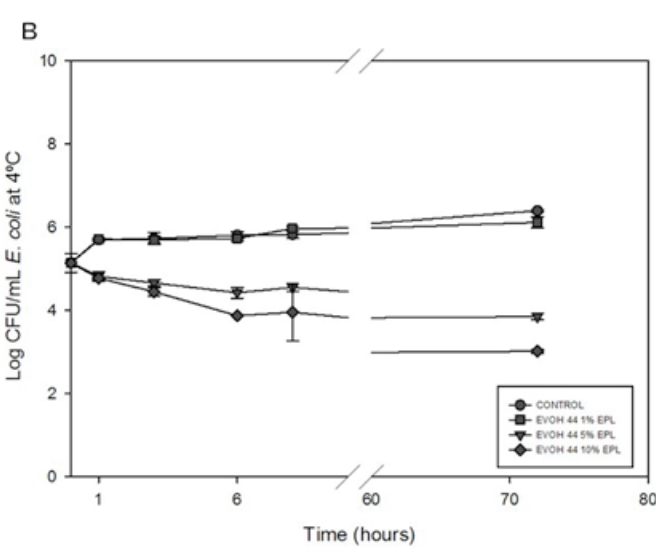

Figure 5. Growth control study with EVOH44 control, 1\%, 5\% and 10\% EPL. A) L. monocytogenes at $4^{\circ} \mathrm{C}$ and B) E. coli at $4^{\circ} \mathrm{C}$.

that the greatest bacterial inhibition was achieved at $37^{\circ} \mathrm{C}$, and films made from copolymers with lower ethylene content were more effective. However, when working with a refrigeration temperature of 4 ${ }^{\circ} \mathrm{C}$, differences in bacterial inhibition caused by both copolymers were less acute. Moreover, a slower release of EPL is expected at $4{ }^{\circ} \mathrm{C}$, which results in a limited concentration of antimicrobial in the medium, and thus a decrease in the effectiveness of the films.

\subsection{Antimicrobial activity of EVOH films containing EPL on surimi microbiota}

Once the antimicrobial effectiveness of the EVOH films had been assessed at refrigeration temperatures, a new study with real food was carried out. EVOH29 and 44 films with 10\% EPL were chosen because these films presented great antimicrobial activity. Surimi sticks were individually wrapped with these films and stored at $4{ }^{\circ} \mathrm{C}$ for 6 days. Samples without film and samples wrapped with film without EPL were prepared as controls. The samples were subjected to microbiological analysis on days 1 , 3 and 6 of refrigerated storage. The results of microbiological counts of the surimi samples are shown in Table 5. It must be pointed out that no differences were found between unwrapped samples and samples wrapped with film without EPL (data not shown).

On the first day of storage no growth of enterobacteriaceae, lactic acid bacteria, psychrotrophic bacteria, total aerobic count and Pseudomonas bacteria was observed in any sample (data not shown), and no growth of enterobacteriaceae was detected during the extended refrigerated storage period studied. No growth of these bacteria is considered as an index of fish quality, which is related to storage in ice, washing and evisceration [35]. These results confirm that the surimi samples were made under Good Manufacturing Practice (GMP), ensuring the quality of the products.

Lactic acid bacteria are commonly found in seafood products, and bacterial counts tend to increase during extended refrigerated storage. As can be seen in Table 3, lactic acid bacteria were found in the control sample after three days of refrigerated storage. EVOH films containing 10\% EPL were capable of inhibiting growth of lactic acid bacteria in surimi sticks during the period of time monitored.

Psychrotrophic bacteria are able to grow at refrigeration temperatures and responsible for the aerobic spoilage of fish stored at refrigeration [36], and in this experiment 
their proliferation was observed after the third day of storage. Bacterial growth was also observed for samples wrapped with active films: samples wrapped with EVOH29 incorporating 10\% EPL presented a $1.45 \mathrm{log}$ inhibition at the third day and a 2.16 log inhibition at the end of storage compared with the control; when wrapped with EVOH44, a 1.07 log reduction was achieved at the third day of storage and a 1.71 log reduction at the end of the storage period.

Total aerobic bacterial counts appeared in the control samples at the third day of storage (2.34 log) and the aerobic population increased by ca. 1 log at the end of the storage period. A bactericidal effect was observed when surimi sticks were wrapped with EVOH29 containing 10\% EPL during the storage time, whereas when EVOH44 films were used microbial aerobic bacterial growth was observed at the $6^{\text {th }}$ day of storage. With regard to Pseudomonas proliferation in the surimi samples, Table 3 shows that bacterial growth was detected in control samples on the third day of storage. EVOH29 films with 10\% EPL exerted total inhibition on day 3, whereas a 0.68 log reduction was achieved with EVOH44 compared with the control. On day 6 of storage, $1.43 \mathrm{log}$ and $1.00 \mathrm{log}$ reductions were found with EVOH29 and EVOH44 with 10\% EPL, respectively, compared with the control.

It has also been demonstrated in previous studies that count between $2.00 \mathrm{log}$ and 4.00 log were found in total aerobic plate and total psychrophilic bacteria [37, 38].

It is worth pointing out that no growth

Table 3. Enumeration of microbial population in surimi: Lactic acid bacteria, Psychrotrophic bacteria, Total aerobic count and Pseudomonas expressed as logarithm of colony forming units per g (Log (CFU/g)) and logarithm reduction value (LRV).

Day 3

Day 6

\begin{tabular}{|c|c|c|c|c|}
\hline & Log (CFU/mL) & LRV & $\log (\mathrm{CFU} / \mathrm{mL})$ & LRV \\
\hline \multicolumn{5}{|c|}{ Lactic acid bacteria } \\
\hline CONTROL & $3.45 \pm 0.23$ & & $3.89 \pm 0.15$ & \\
\hline EVOH29 10\% EPL & Total inhibition & 3.45 & Total inhibition & 3.89 \\
\hline EVOH44 10\% EPL & Total inhibition & 3.45 & Total inhibition & 3.89 \\
\hline \multicolumn{5}{|c|}{ Psychrotrophic bacteria } \\
\hline CONTROL & $3.09 \pm 0.14 b$ & & $5.00 \pm 0.13 b$ & \\
\hline EVOH29 10\% EPL & $1.64 \pm 0.61 a$ & 1.45 & $2.84 \pm 0.11 a$ & 2.16 \\
\hline EVOH44 10\% EPL & $2.02 \pm 0.37 a$ & 1.07 & $3.29 \pm 0.09 a$ & 1.71 \\
\hline \multicolumn{5}{|c|}{ Total aerobic count } \\
\hline CONTROL & $2.34 \pm 0.06$ & & $3.18 \pm 0.02 b$ & \\
\hline EVOH29 10\% EPL & Total inhibition & 2.34 & Total inhibition & 3.18 \\
\hline EVOH44 10\% EPL & Total inhibition & 2.34 & $1.90 \pm 0.24 a$ & 1.28 \\
\hline \multicolumn{5}{|c|}{ Pseudomonas } \\
\hline CONTROL & $3.04 \pm 0.12 b$ & & $3.63 \pm 0.03 b$ & \\
\hline EVOH29 10\% EPL & Total inhibition & 3.04 & $2.20 \pm 0.10 a$ & 1.43 \\
\hline EVOH44 10\% EPL & $2.36 \pm 0.14 a$ & 0.68 & $2.62 \pm 0.11 a$ & 1.01 \\
\hline
\end{tabular}

${ }^{a^{-c}}$ Different letters in the same column for each microorganisms indicate significant differences in antimicrobial effectiveness of different EVOH films (Turkey's adjusted analysis of variance, $P<0.05)$. 
of yeast and moulds was observed in any sample during the storage period.

It can be concluded from this experiment that the active films developed provide inhibition of lactic acid bacteria and total aerobic count, whereas the psychrotrophic and Pseudomonas counts decreased with respect to the control by the end of storage at $4{ }^{\circ} \mathrm{C}$, when the concentration of the agent on the surimi surface is expected to be higher.

\subsection{Antimicrobial activity of EVOH films incorporating EPL on surimi inoculated with L. monocytogenes and E. coli}

Surimi sticks were surface inoculated with L. monocytogenes and E. coli, wrapped with EVOH29 and EVOH44 films with 10\% EPL, and stored for 6 days at $4{ }^{\circ} \mathrm{C}$. Samples without film and samples wrapped with EVOH29 and EVOH44 films without EPL were prepared as controls. With regard to bacterial growth in control samples and in samples wrapped with EVOH with EPL, no significant differences were found. Fig. 6 shows the inhibitory effect of EVOH29 with 10\% EPL on L. monocytogenes: after 1 day of storage, a reduction of 1.76 log was observed; this value was maintained until the $3^{\text {rd }}$ day of storage and increased to 2.76 log reductions at the end of the storage period. Regarding the samples contaminated

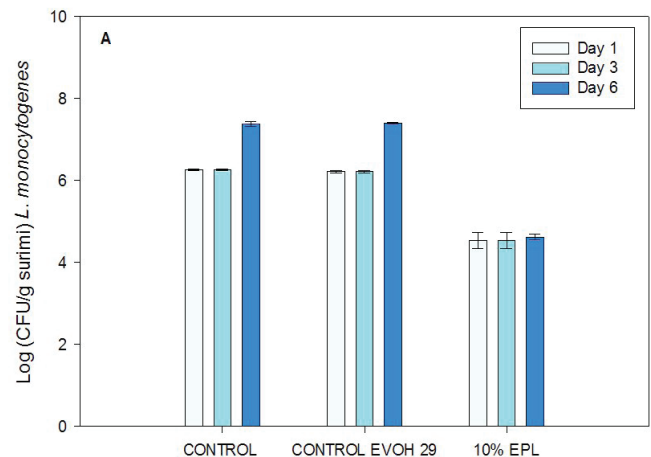

with E. coli, the reduction was ca. 1 log during the entire storage time.

Fig. 7 shows the inhibitory effect of EVOH44 with 10\% EPL against L. monocytogenes and E. coli. L. monocytogenes was reduced by ca. 1 log during the entire storage period. On the other hand, E. coli reduction increased at the end of storage, on the $6^{\text {th }}$ day of storage. The total food-borne bacteria counts of surimi wrapped with the active samples showed a significant decrease in comparison with the control sample.

Comparing the results obtained above with the in vitro test with TSB, it can be observed that a higher concentration of EPL would be necessary to produce total inhibition against L. monocytogenes and E. coli. The antimicrobial activity of the films was probably reduced because of an interaction of the antimicrobial agent with some components of the food matrix, reducing its availability to kill bacteria. Moreover, the kinetics of release and the amount of EPL released to the media may change when assays are made with a solid food instead of a liquid medium. This behaviour has also been reported in previous works. Geornaras et al. (2007) demonstrated that the antimicrobial activity of epsilon-polylysine decreased against L. monocytogenes when was tested in six food products compared with the results obtained in vitro assays ca-

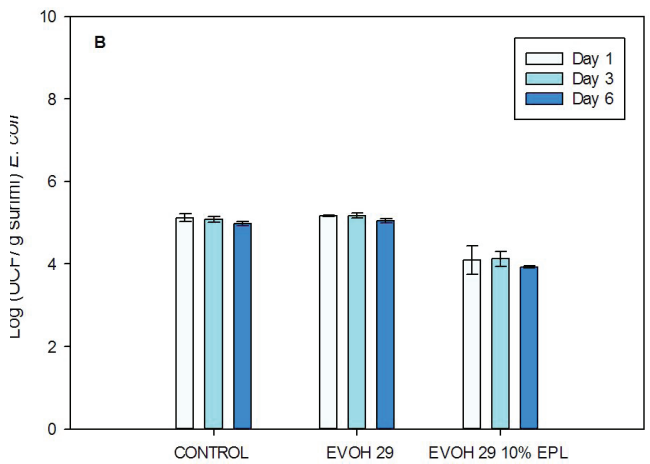

Figure 6. Antimicrobial activity of EVOH29 films with 10\% EPL on surimi sticks inoculated with (A) L. monocytogenes and (B) E. coli. 

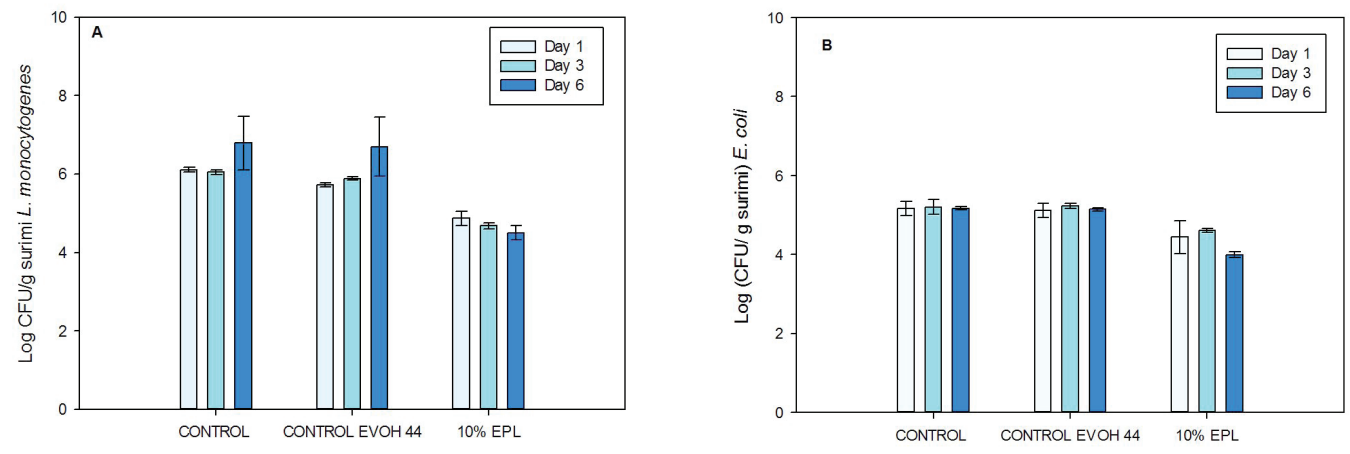

Figure 7. Antimicrobial activity of EVOH44 films with 10\% EPL on surimi sticks inoculated with (A) L. monocytogenes and (B) E. coli.

rried out in broth liquid media. The authors also showed that the antimicrobial effect of active films on surimi products was higher against $L$. monocytogenes than against $E$. coli, as it has been shown throughout this work.

The direct addition of antimicrobial agents into surimi sticks was also studied by other authors [39, 40]. Direct incorporation of the antimicrobial into the food produces an immediate reduction of bacterial populations but this may not prevent the recovery of injured cells or the growth of cells that were not destroyed by direct addition if residues of the antimicrobial are rapidly depleted [41]. Therefore, antimicrobial active films are an excellent technology to extend food shelf-life, providing a continuous antimicrobial effect on the food during extended exposure.

An inadequate consumer knowledge on how to store ready-to-eat food at home, at the right refrigerated temperature, has led to higher risks of L. monocytogenes growth [42]. L. monocytogenes and E. coli are pathogens commonly detected in ready-to-eat products because of their wide distribution in food factories, especially affecting interior surfaces of equipment that are complicated to clean, water and utensils. Thus the chances of surimi recontamination with these food-borne bacteria after post-process procedures are very high. Low temperature control during processing, shipment and storage may not be sufficient to control bacterial growth adequately. Therefore, to increase food safety and extend the shelf life of ready-to-eat surimi products during storage time, it is necessary to complement the post-processing action to control the growth of pathogens L. monocytogenes and E. coli. 


\section{CONCLUSIONS}

Films made from EVOH29 and EVOH44 copolymers incorporating several amounts of EPL were successfully developed by casting, being continuous and transparent. Their optical properties represented changes with respect to the control samples only at the higher concentration of EPL (10\%), increasing significantly but slightly the chroma. The amount of EPL capable of migrate from the copolymer films to liquid medium was quantified revealing that films possessing a lower percentage of ethylene released a greater amount of EPL. Bacterial growth studies carried out at 37 and $4{ }^{\circ} \mathrm{C}$ with L. monocytogenes and E. coli in the presence of the films incorporating EPL showed that a greater bacterial inhibition was achieved at $37^{\circ} \mathrm{C}$ and EVOH29 were more effective than EVOH44 films inhibiting bacterial growth. In vivo experiments carried out with surimi sticks inoculated with pathogen bacteria and wrapped in EVOH29 and EVOH44 with 10\% of EPL, produced a reduction in the microbial load thus increasing the microbiological shelf life of the product at refrigeration temperatures. Therefore, the results obtained in this work provide strong evidence of the antimicrobial effect of active EVOH films on the survival of $L$. monocytogenes and E. coli in vitro and inoculated into surimi sticks stored under refrigeration temperatures. It was also concluded that E. coli was more resistant against EPL than L. monocytogenes. The present study shows that active packaging is a non-thermal preservation technology which could be implemented to improve the microbiological stability of ready-to-eat surimi-derived products.

\section{Acknowledgements}

The authors acknowledge the financial support of the Spanish Ministry of Economy and Competitiveness, projects AGL2012-39920-C03-01, and fellowship funding for V. M.-G. 


\section{REFERENCES}

[1] M. Tzschoppe, A. Martin, L. Beutin, A rapid procedure for the detection and isolation of enterohaemorrhagic Escherichia coli (EHEC) serogroup O26, O103, O111, O118, O121, O145 and 0157 strains and the aggregative EHEC 0104:H4 strain from ready-to-eat vegetables, International Journal of Food Microbiology, 152 (2012) 19-30.

[2] V. Muriel-Galet, J.P. Cerisuelo, G. Lopez-Carballo, M. Lara, R. Gavara, P. Hernandez-Munoz, Development of antimicrobial films for microbiological control of packaged salad, International Journal of Food Microbiology, 157 (2012) 195-201.

[3] H.H. Huss, L.V. Jorgensen, B.F. Vogel, Control options for Listeria monocytogenes in seafoods, International Journal of Food Microbiology, 62 (2000) 267-274.

[4] R.L. Buchanan, M.P. Doyle, Foodborne disease significance of Escherichia coli O157:H7 and other enterohemorrhagic E-coli, Food Technology, 51 (1997) 69-76.

[5] P.S. Mead, P.M. Griffin, Escherichia coli O157:H7, Lancet, 352 (1998) 1207-1212.

[6] FAO, Further processing of fish. Fisheries and aquaculture department, (2005).

[7] V. Venugopal, F. Shahidi, Value-added products from underutilized fish species, Critical Reviews in Food Science and Nutrition, 35 (1995) 431-453.

[8] S. Miya, H. Takahashi, T. Ishikawa, T. Fujii, B. Kimura, Risk of Listeria monocytogenes Contamination of Raw Ready-To-Eat Seafood Products Available at Retail Outlets in Japan, Applied and Environmental Microbiology, 76 (2010) 3383-3386.

[9] K. Kaneko, H. Hayashidani, Y. Ohtomo, J. Kosuge, M. Kato, K. Takahashi, Y. Shiraki, M. Ogawa, Bacterial contamination of ready-toeat foods and fresh products in retail shops and food factories, Journal of Food Protection, 62 (1999) 644-649.
[10] J.W. Park, Surimi and surimi seafood, CRC Press, Boca Raton, FL, 2014.

[11] P. Suppakul, J. Miltz, K. Sonneveld, S.W. Bigger, Active packaging technologies with an emphasis on antimicrobial packaging and its applications, Journal of Food Science, 68 (2003) 408-420.

[12] S. Shima, H. Sakai, Polylysine produced by Streptomyces, Agricultural and Biological Chemistry, 41 (1977) 1807-1809.

[13] S. Shima, H. Matsuoka, T. Iwamoto, H. Sakai, Antimicrobial action of epsilon-poly-L-lysine. Journal Antibiotics, 37 (1984) 1449-1455.

[14] J. Hiraki, T. Ichikawa, S. Ninomiya, H. Seki, K. Uohama, S. Kimura, Y. Yanagimoto, J.W. Barnett, Use of ADME studies to confirm the safety of epsilon-polylysine as a preservative in food, Regulatory Toxicology and Pharmacology, 37 (2003) 328-340.

[15] J. Hiraki, Basic and applied studies on $\boldsymbol{\varepsilon}$-polylysine, Journal of Antibacterial Antifungal Agents Japan, 23 (1995) 349-493.

[16] J. Hiraki, $\boldsymbol{\varepsilon}$-Polylysine, its development and utilization, Fine Chemistry 29 (2000) 18-25.

[17] FDA, Agency reponse letter GRAS Notice No. GRN 00135, (2004).

[18] K.G. Zinoviadou, K.P. Koutsoumanis, C.G. Biliaderis, Physical and thermo-mechanical properties of whey protein isolate films containing antimicrobials, and their effect against spoilage flora of fresh beef, Food Hydrocolloids, 24 (2010) 49-59.

[19] S.-S. Chang, W.-Y.W. Lu, S.-H. Park, D.H. Kang, Control of foodborne pathogens on ready-to-eat roast beef slurry by epsilon-polylysine, International Journal of Food Microbiology, 141 (2010) 236-241.

[20] Y. Chang, L. McLandsborough, D.J. McClements, Cationic Antimicrobial (epsilonPolylysine)-Anionic Polysaccharide (Pectin) Interactions: Influence of Polymer Charge on 
Physical Stability and Antimicrobial Efficacy, Journal of Agricultural and Food Chemistry, 60 (2012) 1837-1844.

[21] I.U. Unalan, K.D.A. Ucar, I. Arcan, F. Korel, A. Yemenicioglu, Antimicrobial Potential of Polylysine in Edible Films, Food Science and Technology Research, 17 (2011) 375-380.

[22] V. Muriel-Galet, G. Lopez-Carballo, R. Gavara, P. Hernandez-Munoz, Antimicrobial food packaging film based on the release of LAE from EVOH, International Journal of Food Microbiology, 157 (2012) 239-244.

[23] V. Muriel-Galet, J.P. Cerisuelo, G. LopezCarballo, S. Aucejo, R. Gavara, P. HernandezMunoz, Evaluation of EVOH-coated PP films with oregano essential oil and citral to improve the shelf-life of packaged salad, Food Control, 30 (2013) 137-143.

[24] C. Lopez de Dicastillo, C. Nerin, P. Alfaro, R. Catala, R. Gavara, P. Hernandez-Munoz, Development of New Antioxidant Active Packaging Films Based on Ethylene Vinyl Alcohol Copolymer (EVOH) and Green Tea Extract, Journal of Agricultural and Food Chemistry, 59 (2011) 7832-7840.

[25] C. Lopez-de-Dicastillo, J.M. Alonso, R. Catala, R. Gavara, P. Hernandez-Munoz, Improving the antioxidant protection of packaged food by incorporating natural flavonoids into ethylenevinyl alcohol copolymer (EVOH) films, Journal of Agricultural and Food Chemistry, 58 (2010) 10958-10964.

[26] C. Lopez-de-Dicastillo, D. Pezo, C. Nerin, G. Lopez-Carballo, R. Catala, R. Gavara, P. Hernandez-Munoz, Reducing Oxidation of Foods Through Antioxidant Active Packaging Based on Ethyl Vinyl Alcohol and Natural Flavonoids, Packaging Technology and Science, 25 (2012) 457-466.

[27] S. Aucejo, R. Catala, R. Gavara, Interactions between water and EVOH food packaging films, Food Science and Technology International, 6 (2000) 159-164.
[28] E.T. Kang, K.L. Tan, K. Kato, Y. Uyama, Y. Ikada, Surface modification and functionalization of polytetrafluoroethylene films, Macromolecules, 29 (1996) 6872-6879.

[29] E. Uchida, Y. Uyama, Y. Ikada, Sorption of Low-molecular-weight anions into thin polycation layers grafted onto a film, Langmuir, 9 (1993) 1121-1124.

[30] M100-S18, Performance Standards for Antimicrobial Susceptibility Testing: Eighteenth Informational Supplement, (2008).

[31] V. Muriel-Galet, G. López-Carballo, P. Hernández-Muñoz, R. Gavara, Characterization of ethylene-vinyl alcohol copolymer containing lauril arginate (LAE) as material for active antimicrobial food packaging, Food Packaging and Shelf Life 1 (2013) 10-17.

[32] A.L. Brandt, A. Castillo, K.B. Harris, J.T. Keeton, M.D. Hardin, T.M. Taylor, Inhibition of Listeria monocytogenes by Food Antimicrobials Applied Singly and in Combination, Journal of Food Science, 75 (2010) 557-563.

[33] Y.T. Ho, S. Ishizaki, M. Tanaka, Improving emulsifying activity of epsilon-polylysine by conjugation with dextran through the Maillard reaction, Food Chemistry, 68 (2000) 449-455.

[34] M.R. Adams, M.O. Moss, Food Microbiology, The Royal Society of Chemistry Cambrigde, UK., 2008.

[35] B. Zambuchini, D. Fiorini, M.C. Verdenelli, C. Orpianesi, R. Ballini, Inhibition of microbiological activity during sole (Solea solea L.) chilled storage by applying ellagic and ascorbic acids, LWT-Food Science and Technology, 41 (2008) 1733-1738.

[36] A. Gunlu, E. Koyun, Effects of Vacuum Packaging and Wrapping with Chitosan-Based Edible Film on the Extension of the Shelf Life of Sea Bass (Dicentrarchus labrax) Fillets in Cold Storage $\left(4^{\circ} \mathrm{C}\right)$, Food and Bioprocess Technology, 6 (2013) 1713-1719. 
[37] M. Coton, C. Denis, P. Cadot, E. Coton, Biodiversity and characterization of aerobic sporeforming bacteria in surimi seafood products, Food Microbiology, 28 (2011) 252-260.

[38] R.K. Singh, A.K. Balange, Characteristics of pink perch (Nemipterus japonicus) surimi at frozen temperature, Journal of Food Processing and Preservation, 29 (2005) 75-83.

[39] J. Li, Q. Han, W. Chen, L. Ye, Antimicrobial activity of Chinese bayberry extract for the preservation of surimi, Journal of the Science of Food and Agriculture, 92 (2012) 2358-2365.

[40] H.Y. Ting, S. Ishizaki, M. Tanaka, Epsilonpolylysine improves the quality of surimi products, Journal of Muscle Foods, 10 (1999) 279 294.

[41] Y.D. Chi-Zhang, K.L. Yam, M.L. Chikindas, Effective control of Listeria monocytogenes by combination of nisin formulated and slowly released into a broth system, International Journal of Food Microbiology, 90 (2004) 15-22.

[42] P. Gambarin, C. Magnabosco, M.N. Losio, E. Pavoni, A. Gattuso, G. Arcangeli, M. Favretti, Listeria monocytogenes in Ready-to-Eat Seafood and Potential Hazards for the Consumers, International Journal of Microbiology, 2012 (2012) 497635-497635. 


\section{CHAPTER III.}

\section{DEVELOPMENT OF}

ANTIMICROBIAL FILMS

COMBINIG VOLATILE AND

NON-VOLATILE COMPOUNDS

\section{ARTICLE 7.}

ANTIOXIDANT AND ANTIMICROBIAL PROPERTIES OF ETHYLENE VINYL ALCOHOL COPOLYMER FILMS BASED ON THE RELEASE OF OREGANO ESSENTIAL OIL AND GREEN TEA EXTRACT COMPONENTS 

ANTIOXIDANT AND

ANTIMICROBIAL PROPERTIES

OF ETHYLENE VINYL ALCOHOL

COPOLYMER FILMS BASED ON

THE RELEASE OF OREGANO

ESSENTIAL OIL AND GREEN TEA

EXTRACT COMPONENTS

Virginia Muriel-Galet ${ }^{1}$, Marlene J. Cran ${ }^{2}$, Stephen W. Bigger ${ }^{2}$, Rafael Gavara*1 and Pilar Hernández-Muñoz ${ }^{1}$

Journal of Food Engineering, 2015, 149, 9-16

1 Packaging Lab, Instituto de Agroquímica y Tecnología de Alimentos, IATA-CSIC, Av. Agustín Escardino 7, 46980 Paterna, SPAIN, Phone: +34-963900022, Fax: +34-963636301.

2 Institute for Sustainability and Innovation, Victoria University, Werribee Campus, PO Box 14428, Melbourne, 8001, Australia. 


\section{ABSTRACT}

Polymer films with antioxidant and antimicrobial properties were manufactured for the active packaging of food products. Green tea extract (GTE) and oregano essential oil (OEO) were incorporated in an ethylene-vinyl alcohol copolymer (EVOH). Release studies of the main active components of the films into three food simulants, 3\% acetic acid, 10\% ethanol and $50 \%$ ethanol, were conducted at $4{ }^{\circ} \mathrm{C}$ and $23^{\circ} \mathrm{C}$. The total antioxidant activity at equilibrium was measured in the food simulants and the antimicrobial capacity of the films was tested in vitro against Listeria monocytogenes, Escherichia coli and Penicillium expansum. The results suggest that the release kinetics depend on the affinity between the active agents and the food simulants. In general, the fastest diffusion was obtained when films were exposed to 50\% ethanol and that effect was concurrent with greater antioxidant efficiencies. The films also showed microbial growth inhibition in liquid media and in vapour phases, demonstrating that the developed films show strong potential for development as active food packaging films.

Keywords: Green tea extract, oregano essential oil, ethylene vinyl alcohol copolymer, antimicrobial packaging, antioxidant packaging. 


\section{INTRODUCTION}

Traditional food packaging methods do not always provide the required shelf-life to allow a satisfactory commercialization of foods, particularly perishable fresh or minimally-processed products [1]. Active packaging with antioxidant or antimicrobial properties can improve fresh food stability and potentially offer shelf-life extension to certain foods. Current trends in active packaging include the incorporation of active natural agents into the polymeric packaging materials $[2,3]$. In these developments, the time-controlled release of such substances into the food has the potential to provide prolonged food safety and quality. Polymers are very attractive in active packaging applications since the well-established mass transport properties (permeation, sorption and migration) can constitute the mechanism of action of the active packaging system. However, such release requires certain control, especially to initiate the action at the correct time. Recently, ethylene-vinyl alcohol copolymers (EVOH) have been explored as an active inner coating on diverse substrate films [4, 5]. In these systems, the high affinity between EVOH and water, which results in severe plasticization of the copolymer when it is exposed to foods with high water activity, was used as a triggering mechanism for the film activity.

Green tea is considered to be a healthy product with its consumption linked to lower incidences of various pathological conditions due to its reported anti-inflammatory, anti-tumour, antioxidative and antimicrobial properties [6]. The chemical composition of green tea is complex and the activity of its components can vary significantly with climate and seasons. The most important bioactive constituents of green tea include polyphenols or flavonoids such as catechins, alkaloids such as caffeine, amino acids, volatiles and minerals $[6,7]$. It is known that the mixture of catechins is responsible for the high antioxidant effect of green tea, and other reports have shown that different types of catechins are responsible for its overall antimicrobial activity [8]. Due to the advantageous properties and classification as a food additive by the European Union (EU), green tea extracts (GTEs) have been incorporated in different food packages in order to extend product shelf-life based on their inherent antioxidant properties [9]. However, reports on the use of GTEs as antimicrobial agents for food-packaging applications are limited. Nevertheless, the thermal degradation of catechins is a limiting factor to be considered on active packaging applications [10].

Oregano essential oil (OEO) is recognised as a natural antimicrobial agent with a strong potential for food preservation and is classified as a food additive by the EU. Similarly to GTE, the chemical composition of OEO can vary significantly between season, climate, and geographical location. Several studies have described the wide range of antimicrobial effects of OEOs against food-borne pathogens [11, 12]. Several studies have reported the composition of OEO which commonly includes a mixture of p-cymene, a-terpinene, thymol and carvacrol with the latter two components representing the main antimicrobial constituents that can damage the outer membrane of many types of bacteria [13]. In addition to the antimicrobial characteristics, some studies have reported antioxidant effects of these compounds that protected lard products from oxidation processes $[13,14]$. The used of OEOs as food additives is limited because of their intense aroma that may impart unacceptable organoleptic properties to some food products. Further improvements to the beneficial antimicrobial and antioxidant properties with simultaneously minimizing 
any adverse sensory effects could be achieved with the combined use of these with other natural compounds. Also, the volatile character of the most relevant constituents of OEO needs to be considered in the preparation of packaging materials to obtain an efficient method of incorporation [2, 15].

The aim of this study was to develop EVOH films that simultaneously provide protection against oxidation and microbial deterioration of food products. Films were pre- pared by casting procedure which can be considered as a simulation of industrial film coating by printing procedures [4]. After the incorporation of GTE and/or OEO in EVOH, the characterization of the release of these agents into different food simulants was performed. Finally, the in vitro antioxidant activity and the antimicrobial activity of the systems against Gram-positive L. monocytogenes, Gram-negative E. coli and fungal species P. expansum were also studied.

\section{MATERIALS AND METHODS}

\subsection{Materials, Chemicals and Reagents}

Ethylene vinyl alcohol copolymer with a 29\% molar content of ethylene (EVOH29, Soarnol DT2904RBR), was kindly provided by the Nippon Synthetic Chemical Company (Osaka, Japan). Chemical agents 1-propanol, oregano essential oil (CAS No: 8007-11-2), reagent-grade absolute ethanol, acetic acid, 2,2-diphenyl-1-picrylhydrazyl (95\% free radical) and carvacrol were purchased from Sigma (Madrid, Spain). The green tea extract was supplied from Plantextrakt (The Nature Network, Baceiredo S.L., Vitoria, Spain). Caffeine, catechin, epigallocatechin were purchased from Fluka Biochemika (Barcelona, Spain). Trolox (( \pm )-6- Hydroxy-2,5,7,8tetramethylchromane-2-carboxylic acid) was purchased from Sigma (Madrid, Spain). Water was obtained from a Milli-Q Plus purification system (Millipore, Molsheim, France).

\subsection{Film Preparation}

Film samples were prepared according to a process previously reported [16] . Briefly, EVOH29 was dissolved in a 50\% v/v 1-propanol/water mixture at $50^{\circ} \mathrm{C}$. The GTE and $\mathrm{OEO}$ were added to the film-forming solu- tion at a concentration of 5\% w/w with respect to the dry polymer weight. The films were prepared by firstly spreading the solution on a flat surface with a coating bar and then evaporating the solvents with hot air. Films of EVOH29 without active compounds, with 5\% w/w GTE (EVOH29-GTE), with 5\% w/w OEO (EVOH29-OEO) and with $5 \%$ w/w of each, GTE and OEO (EVOH29GTE+OEO) were prepared. The average film thickness of the film samples was $20 \pm 2 \mu \mathrm{m}$ (individually measured before each experiment). Samples were stored under dry conditions in aluminium foil until use.

\subsection{Differential Scanning Calorimetry}

The thermal properties were determined with a Mettler Toledo Differential Scanning Calorimetry (DSC) 1 instrument. The glass transition $\left(\mathrm{T}_{\mathrm{g}}\right)$ and melting $(\mathrm{Tm})$ temperatures and the melting enthalpy $(\triangle H \mathrm{~m})$ were calculated using STAR ${ }^{\mathrm{e}}$ Evaluation Software (Mettler Toledo). ( $\triangle H \mathrm{H})$ values were corrected to account the percentage of polymer actually introduced in the pan. Film samples of EVOH29, EVOH29-GTE, EVOH29OEO, and EVOH29-GTE+OEO were dried for 1 week in a desiccator over $\mathrm{P}_{2} \mathrm{O}_{5}$ before analysis. Thermograms were obtained by 
heating samples encapsulated in $40 \mu \mathrm{L}$ crucibles from $25^{\circ} \mathrm{C}$ to $220^{\circ} \mathrm{C}$, cooling to $25^{\circ} \mathrm{C}$, and a second heating to $220^{\circ} \mathrm{C}$. All heating and cooling rates were $10^{\circ} \mathrm{C} \mathrm{min}^{-1}$.

\subsection{Optical properties}

The film color was determined using a Konica Minolta CR-400 Chroma Meter (Konica Minolta Sensing, Inc., Osaka, Japan). The films were placed on the surface of a standard white plate and three measurements were taken of each sample. The measurements were repeated in triplicate. The parameters $L^{*}$ (black (0) to white (100)), $a^{*}$ (green $(-)$ to red $\left.(+)\right)$ and $b^{*}$ (blue $(-)$ to yellow $(+))$ were obtained and the polar coordinates, the chroma $C^{*}$ and the hue angle $h^{\circ}$ calculated.

$C^{*}=\sqrt{\left(a^{*}\right)^{2}+\left(b^{*}\right)^{2}} ; h^{\circ}=\arctan \left(\frac{a^{*}}{b^{*}}\right)$

\subsection{Quantification of GTE and OEO Com- ponents}

The concentrations of epicatechin, catechin and caffeine, that are the main relevant compounds with antimicrobial and antioxidant activity of GTE, were determined using high performance liquid chromatography (HPLC). A Shimadzu GCU-20A5 HPLC instrument equipped with a $250 \times$ $4.6 \mathrm{~mm}, 5 \mu \mathrm{m}$ column and UV-visible absorbance detector set at $220 \mathrm{~nm}$ was used. The mobile phase was acetonitrile/water 10:90\% v/v containing 0.1\% phosphoric acid at $1 \mathrm{~mL} \mathrm{~min}^{-1}$ flow rate, the temperature was $23^{\circ} \mathrm{C}$ and the injection volume was $15 \mu \mathrm{L}$. The concentration of carvacrol, the major component of OEO, was determined by gas chromatography using a Shimadzu GC-2100 Plus instrument (Shimadzu, Australia) under the following conditions: DB- 5 capillary column $(30 \mathrm{~m} \times 0.32 \mathrm{~mm}$, and $0.50 \mathrm{~mm}$ ); column temperature, $80^{\circ} \mathrm{C}$ to $120^{\circ} \mathrm{C}$ at $5^{\circ} \mathrm{C} / \mathrm{min}$; injector temperature, $250{ }^{\circ} \mathrm{C}$; FID temperature, $300{ }^{\circ} \mathrm{C}$; split ratio, 1/100; carrier gas, $\mathrm{N}_{2}$; flow rate, $2.0 \mathrm{~mL} /$ min; and volume injected, $1 \mu \mathrm{L}$. Calibration for each active agent of OEO and GTE was performed by injecting known amounts of each compound into the respective HPLC or GC instruments.

\subsection{Release into Food Simulants}

The release of the active components of GTE and OEO from EVOH29-GTE+OEO into three food simulants was carried out at $4{ }^{\circ} \mathrm{C}$ and $23^{\circ} \mathrm{C}$. Food simulants $\mathrm{A}, \mathrm{B}$ and D1 were selected according to the European Regulations: A, 10\% v/v ethanol as an aqueous food simulant; B, 3\% v/v acetic acid as an acidic food simulant ( $\mathrm{pH} \leq 4.5$ ); and D1: 50\% v/v ethanol as simulant for foods with a lipophilic character. For the release experiments, $3 \mathrm{~cm}^{2}$ film samples were immersed in $5 \mathrm{~mL}$ of simulant in sealed vials. At various exposure times, films were removed from the sample and the liquid stored at refrigeration temperature in brown vial and analysed within $72 \mathrm{~h}$. The concentration of the main compounds was analysed by GC or HPLC following the procedure described in section 2.5.

\subsection{Antioxidant Activity of EVOH Films}

Once the release processes reached equilibrium, the total antioxidant activity of each film system was measured in each of the three food simulants. The antioxidant activity was measured with a standard antioxidant assay using 2,2-diphenyl-1-pricylhydrazyl (DPPH), a stable radical that absorbs at $517 \mathrm{~nm}$ [17]. The method is based on the bleaching rate of the sample and the percentage inhibition values were calculated according to the following equation:

$\%$ Inhibition $=\left(\left(A_{c}-A_{s}\right) / A_{c}\right) \times 100$

where $A_{c}$ is the control absorbance and $A_{s}$ is the sample absorbance. A previous calibration was performed with known concentrations of Trolox and the final antioxidant activity was expressed in terms of the Trolox concentration. 


\subsection{Preparation of Bacterial and Fungal Cultures}

Cultures of L. monocytogenes CECT 934 (ATCC 19114) and E. coli CECT 434 (ATCC 25922) were obtained from the Spanish Type Culture Collection (CECT, Valencia, Spain) and selected to demonstrate the antimicrobial activity of the EVOH films due to their relevance in food safety. The strains were stored in tryptone soy broth (TSB) with $20 \%$ glycerol at $-80{ }^{\circ} \mathrm{C}$ until needed. For experimental use, the stock was maintained by monthly subculture at $4{ }^{\circ} \mathrm{C}$ on slants of tryptone soy agar (TSA). To obtain early stationary phase cells, a loopful of the strain was transferred to $10 \mathrm{~mL}$ of TSB and incubated at $37{ }^{\circ} \mathrm{C}$ for $18 \mathrm{~h}$, prior to each experiment. Spores of $P$. expansum CECT 2275 were obtained from the Spanish Type Culture Collection (CECT, Valencia, Spain). Cultures of $P$. expansum were grown on potato dextrose agar (PDA) in polystyrene petri dishes for 7 days at $30^{\circ} \mathrm{C}$. The inoculum was collected upon flooding the surface of the plates with sterile peptone water and then scraping the surface with a spatula. A $10 \mathrm{~mL}$ sample of the mould culture suspension was transferred to sterile polypropylene tubes and shaken to obtain a homogenous suspension. Several dilutions were made to obtain $10^{6}$ spores $\mathrm{mL}^{-1}$. The spore count was determined using the improved Neubauer method (Bright- Line Hemacytometer, Hausser Scientific, Horshan, PA).

\subsection{Antimicrobial Activity of Films on Solid Media}

The antimicrobial activity of the prepared films was tested using the agar diffusion method. Samples of $100 \mu \mathrm{L}$ of L. monocytogenes and E. coli bacterial suspensions containing approximately $10^{7} \mathrm{CFU} \mathrm{mL} \mathrm{m}^{-1}$ were spread over a prepared TSA surface. Film disks of $2.5 \mathrm{~cm}$ in diameter were adhered to the lids of petri dishes avoiding direct contact with the microorganism. Plates were incubated at $37^{\circ} \mathrm{C}$ for $24 \mathrm{~h}$ and the diameter of the resulting inhibition zone was measured directly after the incubation period. To test the antifungal activity of the films against $P$. expansum, film disks of $9 \mathrm{~cm}$ in diameter were adhered to the lids of petri dishes. This larger film samples were used to obtain a similar concentration of compound in all the Petri dish since the mould culture was not placed in the centre. Samples of 3 $\mu \mathrm{L}$ of the mould culture suspension with $10^{6}$ spores $\mathrm{mL}^{-1}$ were inoculated in three equidistant points over PDA. Plates were incubated at $25^{\circ} \mathrm{C}$ for 12 days and the diameter of the fungal growth was measured the $3^{\text {rd }}$, $6^{\text {th }}$ and $9^{\text {th }}$ day of storage. After the $9^{\text {th }}$ day, the films were removed from the lid of the Petri dishes and the colony diameter was measured at day 12 to observe any fungicidal effect. The antimicrobial and antifungal activity was also tested on control samples. Two different controls were prepared, films without active agents (GTE and OEO) and samples without films. No differences between the control samples were found and the results are expressed as the mean values of the controls. All of the experiments were performed in triplicate.

\subsection{Antimicrobial Activity of Films in Liquid Media}

The antimicrobial activity of prepared films was tested in liquid media. Cell cultures of each microorganism in the stationary phase (optical density of 0.9 at $600 \mathrm{~nm}$ ) were diluted in TSB and incubated at $37^{\circ} \mathrm{C}$ until reaching the exponential phase (optical density of 0.2 at $600 \mathrm{~nm}$ ). At this stage, $100 \mu \mathrm{L}$ of TSB containing $10^{5} \mathrm{CFU} \mathrm{mL} \mathrm{m}^{-1}$ and $0.25 \mathrm{~g}$ of each film was placed into separate sterile tubes with $10 \mathrm{~mL}$ of TSB and were incubated at $37^{\circ} \mathrm{C}$ for $24 \mathrm{~h}$. Depending on the turbidity of the tubes, serial dilutions were performed using peptone water and plated in petri dishes with $15 \mathrm{~mL}$ of TSA culture medium. Colonies were counted after incubation at $37^{\circ} \mathrm{C}$ for $24 \mathrm{~h}$. Controls without films were also tested and the experiments were performed in triplicate. 


\subsection{Statistical Analysis}

One-way analyses of variance were carried out using the SPSS ${ }^{19} 19$ computer program (SPSS Inc., Chicago, IL, USA). Differences in pairs of mean values were evaluated by the Tukey-b test for a confidence interval of $95 \%$. Data are represented as the mean \pm standard deviation.

\section{RESULTS AND DISCUSSION}

The film casting technique described above was used to produce EVOH films containing of 5\% w/w GTE, 5\% w/w OEO and 5\% $\mathrm{w} / \mathrm{w}$ of both components (nominal concentrations). All films were transparent and without discontinuities, with an average thickness of $20 \pm 2 \mu \mathrm{m}$.

\subsection{Thermal Properties}

In order to study the effect of incorporating the active agents into EVOH29 films on the thermal properties of the base material, the samples were analysed by DSC. Table 1 shows a summary of the key thermal parameters obtained from the first heating process. The $T_{g}$ of the control film was ca. $44^{\circ} \mathrm{C}$, similar to that reported for cast films of EVOH29 [18], but $20^{\circ} \mathrm{C}$ below the value reported by the manufacturer for extruded film. This difference is attributed to the fabrication method since solvent residues trapped in the matrix can plasticize the film [19]. Although the effect is marginal, the addition of GTE and OEO slightly increased the $T_{g}$ in all the samples therefore increasing the film rigidity. Interactions between the $\mathrm{OH}$ groups of the polymer chain with $\mathrm{OH}, \mathrm{CO}$ or $\mathrm{COOH}$ chemical groups of the extract components via hydrogen bonding could potentially cause this observed effect.

Table 1 also shows a summary of the melting behaviour with all $\mathrm{Tm}$ values in the range $176.5 \pm 1^{\circ} \mathrm{C}$, which is $12^{\circ} \mathrm{C}$ lower than the manufacturer's value for extruded films. This is also due to the different fabrication process that, in turn, influences the polymer crystallization process. No significant differences were observed between samples in the $\mathrm{Tm}$ values (endotherm minimum). For the calculated melting enthalpy, only the sample containing both GTE and OEO presented a significant decrease compared to the control film. The high content of additives within the matrix may reduce the ability of the polymer chains to crystallize. Also, it should be noted that the endotherm profiles of the active films were wider than that of the control sample, indicating a more irregular crystalline

Table 1. Thermal properties obtained from DSC thermograms of EVOH film formulations. Glass transition temperature $\left(\mathrm{Tg}_{\mathrm{g}}\right)$, melting point $(\mathrm{Tm})$ and melting enthalpy $(\triangle \mathrm{Hm})$.

\begin{tabular}{rccc} 
Film & $\mathrm{T}_{\mathrm{g}} /{ }^{\circ} \mathrm{C}$ & $\mathrm{Tm}_{\mathrm{m}} /{ }^{\circ} \mathrm{C}$ & $\Delta \mathrm{Hm}_{\mathrm{m}} / \mathrm{J} \mathrm{g}^{-1}$ \\
\hline EVOH29 & $43.9 \pm 0.3^{\mathrm{a}}$ & $176.7 \pm 1.4^{\mathrm{a}}$ & $87.1 \pm 2.7^{\mathrm{b}}$ \\
\hline EVOH29-GTE+OEO & $46.0 \pm 1.1^{\mathrm{b}}$ & $175.7 \pm 0.9^{\mathrm{a}}$ & $86.0 \pm 2.2^{\mathrm{b}}$ \\
\hline EVOH29-GTE & $47.1 \pm 0.9^{\mathrm{b}}$ & $177.0 \pm 1.0^{\mathrm{a}}$ & $88.1 \pm 1.8^{\mathrm{b}}$ \\
\hline EVOH29-OEO & $45.3 \pm 1.1^{\mathrm{ab}}$ & $177.4 \pm 1.0^{\mathrm{a}}$ & $78.9 \pm 1.6^{\mathrm{a}}$ \\
\hline
\end{tabular}

Note: a, b, c indicate significant differences amongst the samples (Tukey's adjusted analysis of variance $P<0.05)$ 
Table 2. Color parameters of EVOH film formulations.

\begin{tabular}{rccccc} 
Film & $\mathbf{L}^{*}$ & $\mathbf{a}^{*}$ & $\mathbf{b}^{*}$ & $\mathbf{C}^{*}$ & $\mathbf{h}^{\mathbf{b}}$ \\
\hline EVOH29 & $94.43 \pm 0.54^{\mathrm{a}}$ & $-0.17 \pm 0.03^{\mathrm{a}}$ & $-0.16 \pm 0.06^{\mathrm{a}}$ & $0.12 \pm 0.07^{\mathrm{a}}$ & $208.4 \pm 6.19^{\mathrm{a}}$ \\
\hline EVOH29-GTE+OEO & $81.37 \pm 0.24^{\mathrm{b}}$ & $5.78 \pm 0.04^{\mathrm{b}}$ & $9.02 \pm 0.12^{\mathrm{b}}$ & $7.79 \pm 0.09^{\mathrm{b}}$ & $83.22 \pm 1.85^{\mathrm{b}}$ \\
\hline EVOH29-GTE & $83.21 \pm 0.56^{\mathrm{b}}$ & $6.79 \pm 0.06^{\mathrm{b}}$ & $8.79 \pm 0.05^{\mathrm{b}}$ & $7.56 \pm 0.05^{\mathrm{b}}$ & $84.42 \pm 2.51^{\mathrm{b}}$ \\
\hline EVOH29-OEO & $95.19 \pm 0.63^{\mathrm{a}}$ & $-0.18 \pm 0.04^{\mathrm{a}}$ & $-0.17 \pm 0.03^{\mathrm{a}}$ & $0.15 \pm 0.04^{\mathrm{a}}$ & $210.5 \pm 5.12^{\mathrm{a}}$
\end{tabular}

Note: $\mathrm{a}, \mathrm{b}$ indicate significant differences amongst the values of the same color property of the samples with the same base-copolymer (Turkey's adjusted analysis of variance $P<0.05$ ).

structure probably due to the interruptions occurred during crystallization by the presence of non-polymeric substances (data not shown).

\subsection{Optical Properties}

The color parameters of the film samples are summarised in Table 2. No significant differences in any of the measured colour parameters were found between EVOH29 and EVOH29-OEO. These films were transparent and colourless and, as expected, they exhibited values of $a^{*}$ and $b^{*}$ close to zero. Films in which GTE was incorporated were brownish in color, which is reflected by a significant increase in $a^{*}$ and $b^{*}$ and $a$ reduction in the luminosity $\left(L^{*}\right)$, the chromaticity $\left(C^{*}\right)$ and the hue angle. No significant differences were observed between EVOH29-GTE and EVOH29-GTE+OEO.

(i)

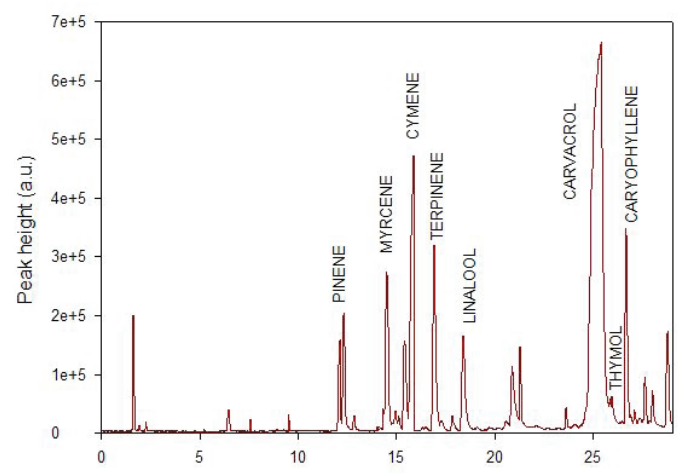

\subsection{Identification of OEO and GTE Compo- nents}

In this study, carvacrol, the main component with antimicrobial and antioxidant activity, was identified and characterized with GC using standards. Figure 1(i) shows that carvacrol is indeed the main constituent of OEO with a concentration of ca. 86\%. Solutions of GTE in alcohol were analyzed by HPLC and a typical chromatogram is shown in Figure 1(ii). The main components shown in the figure were identified using standards.

\subsection{Release into Food Simulants}

To characterize the release of the substances from the films, the solution to Fick's equations considering the boundary conditions of the experiment was used. It was

(ii)

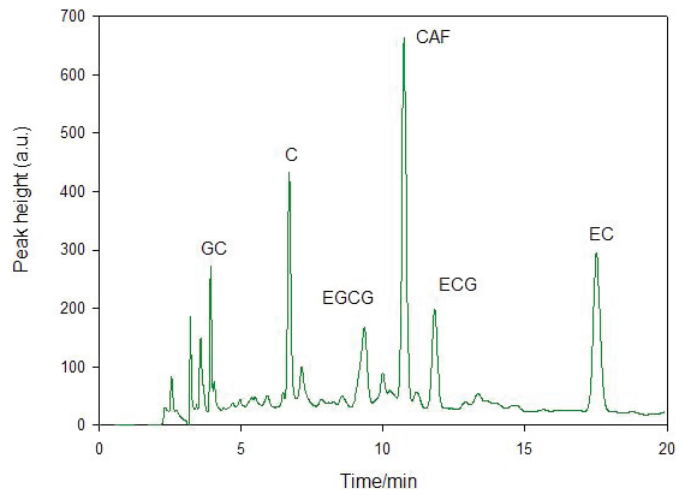

Figure 1. Chromatograms of : (i) OEO with the components: pinene, myrcene, cymene, terpinene, linanool, carvacrol, thymol and caryophyllene and (ii) GTE with main components catechin (C), caffeine (CAFF), gallic acid (GA), epigallocatechin gallate (EGCG), epigallogatechin (EGC), and epicatechin (EC). 


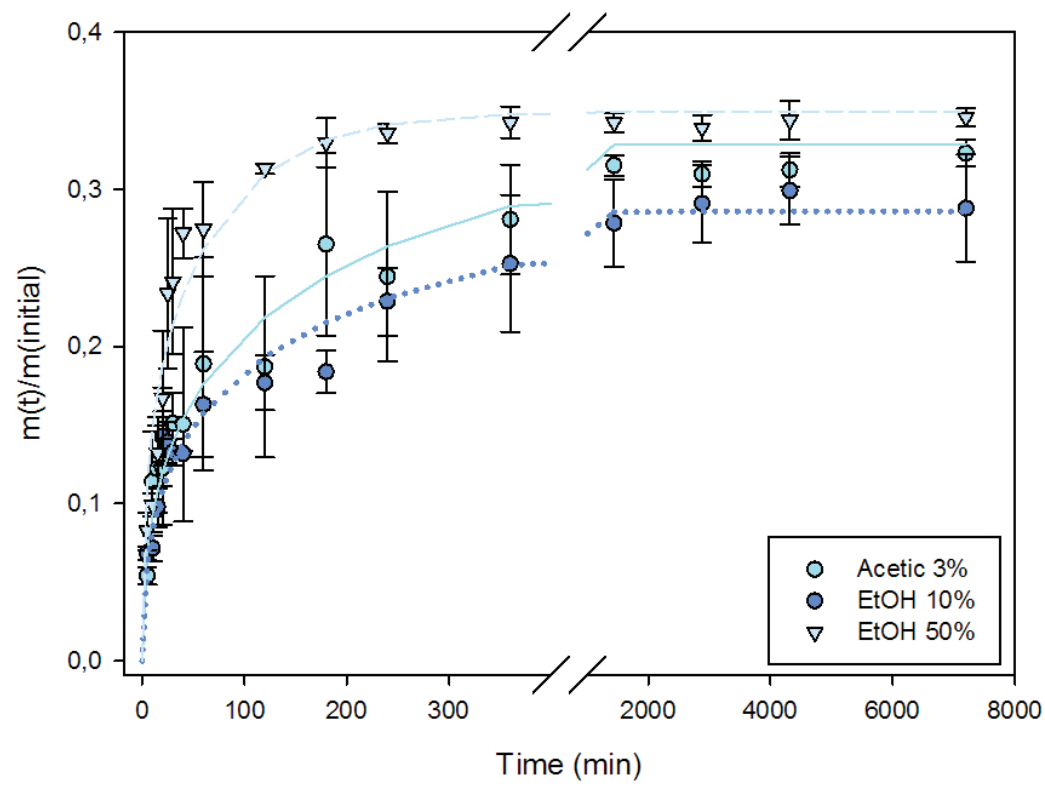

Figure 2. Release of epichatechin from EVOH-GTE+OEO films into aqueous solutions of: (i) 3\% w/w acetic acid, (ii) 10\% v/v ethanol and 50\% v/v ethanol. Symbols represent the experimental data and lines correspond to the theoretical prediction obtained with equation (2).

assumed that the films were isotropic and that the agents were homogenously distributed within the polymer matrix. Due to the drying process, a $20 \%$ loss of carvacrol was considered, value obtained in independent experiments following the procedure described elsewhere [16]. No change was considered in the content of catechins since in previous reports, the content of catechin and quercetin was not changed even when process by extrusion[20]. The film samples were thin enough so as to assume that no release of the agents takes place through the edges and that both surfaces are exposed to the simulant. The partition coefficient, $K$, defined as the ratio of active agent concentrations in the film and in the simulant at infinite time, and the diffusion coefficient, $D$, were assumed to be constant throughout the experiment. Under the conditions of the experiment, the mass, $m(t)$, of agent released from a film of thickness, $l$, at a specific time, $t$, is given by Crank (1975): $m(t)=\frac{c^{0} p V_{s} V_{p}}{V_{s}+K V_{p}}\left(1-\sum_{n-1}^{\infty} \frac{2 a(1+a)}{1+a+a^{2} q^{2} n} \exp \left(4 D q^{2} n t / \ell^{2}\right)\right)$ where $a=V_{s} /\left(K V_{p}\right)$ which represents the ratio between the mass of compound in the liquid and that in the polymer at equilibrium, $V_{s}$ and $V_{p}$ are the volumes of simulant and polymer, $\mathrm{Cp}^{0}$ is the initial concentration of the antimicrobial agent and $\mathrm{qn}_{\mathrm{n}}$ is the positive solution to the equation: $\operatorname{tg}\left(q_{n}\right)=-a q_{n}$.

The mechanism of action of films containing active agents is the release of the incorporated agents into the food product or the surrounding headspace. The extent and kinetics of this release are therefore key parameters that relate to the final antimicrobial or antioxidant efficiency of the active film. Release studies were conducted at different temperatures by exposure of the films to three established food simulants with the concentrations of the separate components determined by GC and HPLC analyses. Figure 2 shows an example of the results obtained for the release of epicatechin at 23 ${ }^{\circ} \mathrm{C}$. The data exhibit typical release profiles from a polymeric film into a liquid of limited volume as evidenced by the asymptotic 
approaches towards equilibrium values. However, it is evident from the plots that a complete release of epicatechin into any of the three tested simulants was not achieved. A similar result was obtained for the migration of each of the other compounds into each of the food simulants at either test temperature (data not shown).

The curves shown in Figure 2 were obtained from equation (3) using the $K$ and $D$ values that yielded the best fit to the experimental data. The theoretical fitted curves are in good agreement with the experimental release data. It is therefore evident that equation (3) adequately predicts the release profiles of the different film formulations. The values of $K$ and $D$ for the different sample/simulant systems are presented in Table 3. From these data, it can be observed that the simulant containing 50\% $\mathrm{V} / \mathrm{v}$ ethanol promoted the greatest amount and fastest release of all compounds as it produced the lowest $K$ and the highest $D$ values. This mixture is a good solvent for the agents incorporated in the polymer and this may explain the high release rates that were observed. In addition, this simulant might produce the highest extent of plasticization and/or swelling of the polymer matrix resulting in a faster rate of diffusion of additive molecules through a more flexible and open polymer structure. Comparing the agents, caffeine was released faster than all other compounds in all simulants, despite it having a lower relative molecular weight than carvacrol. This observation may be explained by the different molecular sizes of the two molecules as the molar volume of caffeine is $133.4 \mathrm{~mL}$ $\mathrm{mol}^{-1}$ whereas that of carvacrol is $154.2 \mathrm{~mL}$ $\mathrm{mol}^{-1}[21,22]$. It is generally accepted that the smaller the molecular size, the faster that molecule diffuses in a polymeric medium $[23,24]$.

The release was also characterized at two temperatures and given that similar $K$ values

Table 3. Values of the partition coefficient, $\mathrm{K}$, at $23^{\circ} \mathrm{C}$ and $4{ }^{\circ} \mathrm{C}$, and the diffusion coefficient, $D$, for the release of the diverse agents incorporated in EVOH29-GTE+OEO films, obtained by fitting equation (2) to the experimental release values.

\begin{tabular}{|c|c|c|c|c|}
\hline $23^{\circ} \mathrm{C}$ & Carvacrol & Epicatechin & Catechin & Caffeine \\
\hline Simulant & $K$ & $K$ & $K$ & $K$ \\
\hline $3 \% \mathrm{v} / \mathrm{v}$ acetic acid & $800 \pm 110$ & $1860 \pm 180$ & $3142 \pm 350$ & $1427 \pm 192$ \\
\hline $10 \% \mathrm{~V} / \mathrm{v}$ ethanol & $785 \pm 260$ & $2010 \pm 230$ & $2751 \pm 350$ & $1272 \pm 125$ \\
\hline \multirow[t]{2}{*}{$50 \%$ v/v ethanol } & $150 \pm 148$ & $1610 \pm 80$ & $2035 \pm 205$ & $1271 \pm 158$ \\
\hline & $\mathrm{D} \times 10^{15} / \mathrm{m}^{2} \mathrm{~s}^{-1}$ & $\mathrm{D} \times 10^{15} / \mathrm{m}^{2} \mathrm{~s}^{-1}$ & $\mathrm{D} \times 10^{15} / \mathrm{m}^{2} \mathrm{~s}^{-1}$ & $\mathrm{D} \times 10^{15} / \mathrm{m}^{2} \mathrm{~s}^{-1}$ \\
\hline $3 \% \mathrm{v} / \mathrm{v}$ acetic acid & $0.79 \pm 0.16$ & $0.38 \pm 0.07$ & $0.19 \pm 0.03$ & $2.76 \pm 1.67$ \\
\hline $10 \% \mathrm{v} / \mathrm{v}$ ethanol & $1.34 \pm 0.80$ & $0.29 \pm 0.06$ & $0.04 \pm 0.01$ & $4.92 \pm 1.10$ \\
\hline $50 \% \mathrm{v} / \mathrm{v}$ ethanol & $1.99 \pm 1.04$ & $1.12 \pm 0.10$ & $2.32 \pm 0.75$ & $2.42 \pm 0.55$ \\
\hline $4^{\circ} \mathrm{C}$ & Carvacrol & Epicatechin & Catechin & Caffeine \\
\hline Simulant & $K$ & $K$ & $K$ & $K$ \\
\hline $3 \% \mathrm{v} / \mathrm{v}$ acetic acid & $795 \pm 110$ & $2178 \pm 302$ & $4631 \pm 602$ & $1356 \pm 150$ \\
\hline $10 \% \mathrm{v} / \mathrm{v}$ ethanol & $798 \pm 128$ & $2520 \pm 380$ & $3233 \pm 404$ & $1444 \pm 221$ \\
\hline \multirow[t]{2}{*}{$50 \% \mathrm{v} / \mathrm{v}$ ethanol } & $328 \pm 118$ & $2430 \pm 255$ & $2500 \pm 187$ & $1265 \pm 303$ \\
\hline & $D \times 10^{15} / \mathrm{m}^{2} \mathrm{~s}^{-1}$ & $\mathrm{D} \times 10^{15} / \mathrm{m}^{2} \mathrm{~s}^{-1}$ & $\mathrm{D} \times 10^{15} / \mathrm{m}^{2} \mathrm{~s}^{-1}$ & $\mathrm{D} \times 10^{15} / \mathrm{m}^{2} \mathrm{~s}^{-1}$ \\
\hline $3 \% \mathrm{v} / \mathrm{v}$ acetic acid & $0.05 \pm 0.01$ & $0.04 \pm 0.01$ & $0.04 \pm 0.01$ & $0.69 \pm 0.13$ \\
\hline $10 \% \mathrm{v} / \mathrm{v}$ ethanol & $0.13 \pm 0.03$ & $0.14 \pm 0.05$ & $0.03 \pm 0.01$ & $3.29 \pm 1.16$ \\
\hline $50 \%$ v/v ethanol & $1.50 \pm 0.10$ & $0.31 \pm 0.06$ & $0.73 \pm 0.28$ & $2.25 \pm 1.26$ \\
\hline
\end{tabular}


were obtained for each compound at 4 and $23^{\circ} \mathrm{C}$, it can be suggested that temperature does not greatly influence the extent of the release process and that the enthalpy associated with this process islow. Conversely, and as expected, increasing the temperature accelerates the diffusion of molecules in the polymer matrix since $D$ is a kinetic parameter with an Arrhenius temperature dependency. Baner, 1995 published an empirical equation that approximately predicts the effect of temperature on the value of $D$. Based on this equation, the predicted ratio between $D\left(23^{\circ} \mathrm{C}\right)$ and $D\left(4^{\circ} \mathrm{C}\right)$ is ca. 10 , much higher than the results obtained in this work. It is possible that the plasticizing effect of the simulant on the polymer matrix influences the $D$ value more significantly such that the effect of temperature is reduced[25].

There are several reports in the literature describing the release processes of active substances from EVOH. Cerisuelo et al. [26] studied the release of carvacrol from EVOH films obtained by casting in a wet atmosphere and reported a $D$ value at $23^{\circ} \mathrm{C}$ of $3 \times 10^{-15} \mathrm{~m}^{2} \mathrm{~s}^{-1}$, slightly higher but close to the values obtained in this work. In that study, the atmosphere was maintained by a wet gas flow stream, which assists with the release and dispersion of the released molecules in the atmosphere, and consequently, reduces the carvacrol concentration at the film surface. In another study, catechin was incorporated into extruded EVOH films with $32 \%$ ethylene molar content and its release into $10 \% \mathrm{v} / \mathrm{v}$ aqueous ethanol solution was monitored [20]. The partition of catechin between the solvent and the polymer was ca. 3000, and the release rate was described by a $D$ value ca. $1.5 \times 10^{-15} \mathrm{~m}^{2} \mathrm{~s}^{-1}$. Both of these values are in good agreement with the results obtained in this work. Lopez de Dicastillo et al. [27] studied the release of GTE incorporated into EVOH by extrusion into several food simulants including $10 \% \mathrm{v} / \mathrm{v}$ aqueous ethanol. The release of caffeine into $10 \% \mathrm{v} / \mathrm{v}$ aqueous ethanol was also analysed in the same study and the values of $K$ and $D$ were found to be 20 and $1.5 \times 10^{-15} \mathrm{~m}^{2} \mathrm{~s}^{-1}$ respectively. Although the diffusion coefficient is in general agreement with the results of the current study, the extent of the release of caffeine differs significantly. The reason for this discrepancy is unclear at present and will require further investigation.

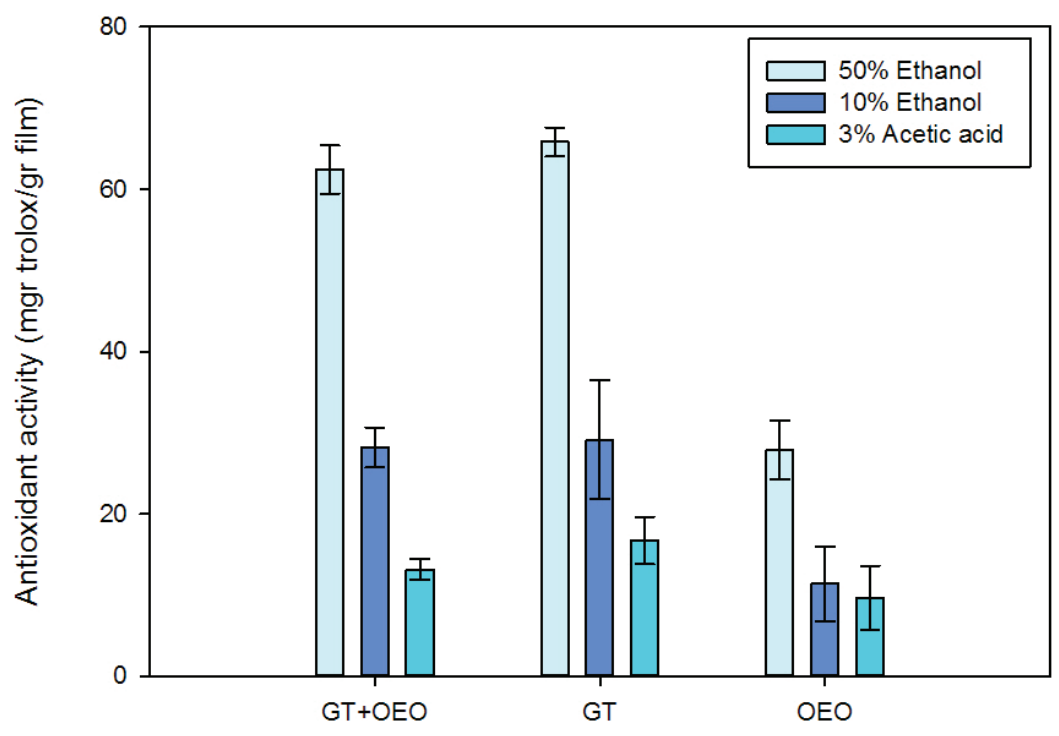

Figure 3. Antioxidant activity of food simulants after exposure to the diverse EVOH29 film samples. 


\subsection{Antioxidant Activity of EVOH Films}

The antioxidant activity of the simulant solutions following exposure to the active films was determined and Figure 3 shows the results expressed as milligrams of Trolox per gram of film. As expected, all three active samples presented antioxidant activity in excess of the control EVOH29 film that produced a null result (not included in the graph). The EVOH29-OEO film demonstrated the lowest antioxidant activity since OEO is primarily known for its antimicrobial properties. This result is in agreement with other studies that have demonstrated that OEO can present some antioxidant activity which can be also attributed to the presence of carvacrol [13]. Samples containing GTE presented antioxidant activities that were significantly higher than that of the EVOH29-OEO in all simulants and the strong antioxidant activity of GTE is derived from the presence of the diverse catechin compounds [28]. Interestingly, there were no significant differences between the EVOH29-GTE+OEO and EVOH29-GTE in any of the three simulants tested suggesting that no synergistic or additive effect was imparted in the film containing the combination of these additives. Instead, the antioxidant activities of the films containing the GTE/OEO mixture were lower even though the differences were not significant. The results of the antioxidant assay were in agreement with the release results in that the higher chemical compatibility of catechins and carvacrol with $50 \% \mathrm{v} / \mathrm{v}$ aqueous ethanol increased the migration and consequently the antioxidant activity.

\subsection{Antimicrobial Activity of EVOH Films}

The antimicrobial activity of the films against L. monocytogenes and E. coli was studied using an agar diffusion method in the vapour phase. Table 4 lists the diameter of the inhibition zone following the incubation period for each of the microorganisms that were tested. The films containing OEO showed a higher inhibitory effect against E. coli $(4.22$ and $4.41 \mathrm{~cm})$. No inhibition zone was formed against L. monocytogenes and E. coli with EVOH 29-GT.

The growth of P. expansum was evaluated by the microatmosphere method in potato dextrose agar. Petri dishes and Figure 4 shows the antifungal effect of EVOH29-GTE, EVOH29-OEO and EVOH29-GTE+OEO after 12 days of storage at $30^{\circ} \mathrm{C}$. As demonstrated in the figure, $\mathrm{EVOH}$ films containing OEO presented a strong effect against fungal growth with significant growth in the presence of films containing GTE.

Table 5 shows the growth of the colony diameters over time and again, the two films containing OEO completely inhibited the growth of $P$. expansum immediately after casting and maintained this effect during the assay. Interestingly, after film removal from the lid, no growth was observed in the dishes stored at $30^{\circ} \mathrm{C}$ for a further 7 days suggesting carvacrol produced a lethal fungicidal effect on the microorganism. In contrast, no inhibition was observed in the tests with EVOH29-GTE films. From days 9 and 12, films were no longer visible in the petri dishes and may have been solubilised in the medium.

Table 4. Inhibition zone of films on the growth of L. monocytogenes and E. coli.

L. monocytogenes

E. coli

\begin{tabular}{rcc}
\hline & Inhibition zone diameter/cm & Inhibition zone diameter/cm \\
\hline Control & Not observed & Not observed \\
\hline EVOH 29-GTE & Not observed & Not observed \\
\hline EVOH 29-GTE+OEO & $3.19 \pm 0.18$ & $4.22 \pm 0.22$ \\
\hline
\end{tabular}




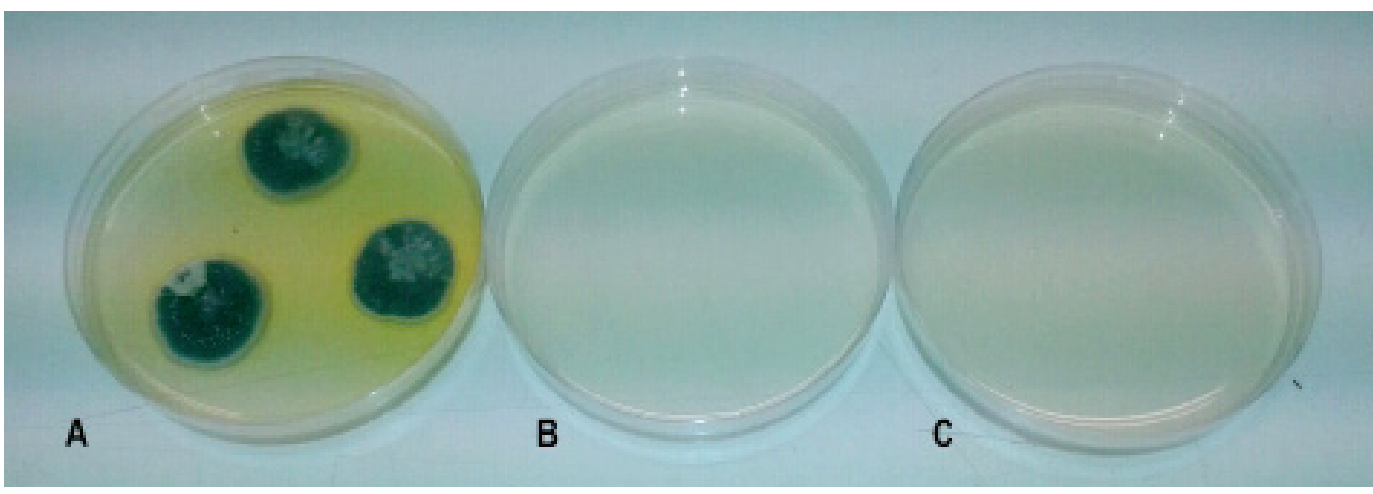

Figure 4. Antifungal effect against P. expansum for the diverse films: (A) EVOH29-GTE, (B) EVOH29$\mathrm{OEO}$, and (C) EVOH29-GTE+OEO.

Table 5. Diameter of P. expansum colony after exposure to the EVOH29 films.

Colony diameter of P. expansum/cm

\begin{tabular}{rcccc}
\hline & Day 3 & Day 6 & Day 9 & Day 12 \\
\hline Control & $1.50 \pm 0.21$ & $2.37 \pm 0.12$ & $2.45 \pm 0.16$ & $2.97 \pm 0.13$ \\
\hline EVOH29-GTE+OEO & Not observed & Not observed & Not observed & Not observed \\
\hline EVOH29-GTE & $1.73 \pm 0.04$ & $2.45 \pm 0.16$ & $2.30 \pm 0.11$ & $3.09 \pm 0.04$ \\
\hline EVOH29-OEO & Not observed & Not observed & Not observed & Not observed \\
\hline
\end{tabular}

Table 6. Antimicrobial activity of films in liquid media against L. monocygones and E. coli.

\begin{tabular}{rcc} 
& L. monocytogenes & E. coli \\
\hline & Log $(\mathrm{CFU} / \mathrm{mL})$ & Log $(\mathrm{CFU} / \mathrm{mL})$ \\
\hline Control & $8.79 \pm 0.04$ & $8.86 \pm 0.09$ \\
\hline EVOH29-GTE+OEO & Total inhibition & Total inhibition \\
\hline EVOH29-GTE & $7.54 \pm 0.01$ & $7.13 \pm 0.14$ \\
\hline EVOH29-OEO & Total inhibition & Total inhibition \\
\hline
\end{tabular}

It is well-established that carvacrol is a volatile phenolic compound with strong antibacterial properties [4, 16, 29-32]. Other authors also demonstrated that this agent is released from the film into the headspace, and acts from the vapour phase on microorganisms producing the observed antimicrobial and antifungal effect [33, 34]. Carvacrol interacts with the cell membrane, producing a distortion of the physical structure and destabilisation of the membrane, thereby increasing the fluidity and the passive permeability. In the case of GTE, the antimicrobial/antifungal constituents may require a liquid medium to be released and produce any observable effect.

The antimicrobial activity of the films in liquid media against L. monocytogenes and E. coli was investigated and Table 6 summarises the results. A total inhibition was observed in the films containing OEO with log reductions of 1.25 and 1.67 obtained for EVOH29-GTE films against L. monocytogenes and E. coli respectively. Again, films containing OEO showed a strong antimicrobial effect as was observed in the vapour phase test. This may be due to the 
plasticizing effect of water on EVOH29 and the high humidity conditions that accelerates the carvacrol release into TSB producing the observed antimicrobial effect. The same phenomenon occurred with GTE releasing into the liquid medium although, as expected, the antimicrobial effect is reduced.
Some studies have reported that GTE catechins are the compounds responsible for the antibacterial activity [8, 35] with catechins binding to the bacterial membrane and adversely affecting a number of cellular processes, such as apoptosis and mitochondrial functionality [36]. The results of the present study show little difference in the antimicrobial activity against Grampositive or Gram-negative bacteria.

\section{CONCLUSIONS}

Antioxidant and antimicrobial active films based on EVOH29 and natural agents, GTE and OEO, were successfully manufactured by casting. Thermal analysis revealed that the incorporation of the agents affected the crystalline structure of EVOH. The optical properties were such that films in which GTE was incorporated were highly colored but those containing OEO were similar to the control. The release of the active agents depended on their affinity for the food simulants that were used and the ability of the simulant to swell the polymer. In this study, the migration was greater in aqueous simulants with high ethanol content and the release of caffeine from GTE was faster than the release into the simulants of all other compounds tested. As expected, the antioxidant activity of the films containing GTE was the most effective and films containing OEO showed a strong antimicrobial activity against the tested microorganisms. Films containing GTE also inhibited the growth of L. monocytogenes and E. coli in liquid media. However, a combination of GTE and OEO in the film did not result in any synergistic or additive antimicrobial or antioxidant effect. Overall, the results suggest that the EVOH29 films with OEO or GTE agents show strong potential for further development as food packaging films. Industrial printing equipment can be used to coat different polymers films such as PP with the active EVOH layer that had been developed in this work.

\section{Acknowledgements}

The authors acknowledge the financial support of the Spanish Ministry of Economy and Competitiveness, projects AGL2012-39920-C03-01, and fellowship funding for V. M.-G. We gratefully acknowledge Mr Joseph Pelle of Victoria University, Melbourne, Australia for technical support with the GC and HPLC experiments. 


\section{REFERENCES}

[1] S. Quintavalla, L. Vicini, Antimicrobial food packaging in meat industry, Meat Science, 62 (2002) 373-380.

[2] P. Suppakul, J. Miltz, K. Sonneveld, S.W. Bigger, Active packaging technologies with an emphasis on antimicrobial packaging and its applications, Journal of Food Science, 68 (2003) 408-420.

[3] J. Gomez-Estaca, C. Lopez-de-Dicastillo, P. Hernandez-Munoz, R. Catala, R. Gavara, Advances in antioxidant active food packaging, Trends in Food Science \& Technology, 35 (2014) 42-51.

[4] V. Muriel-Galet, J.P. Cerisuelo, G. López-Carballo, S. Aucejo, R. Gavara, P. Hernández- Muñoz, Evaluation of EVOH-coated PP films with oregano essential oil and citral to improve the shelf-life of packaged salad, Food Control, 30 (2013) 137-143.

[5] V. Muriel-Galet, G. Lopez-Carballo, R. Gavara, P. Hernandez-Munoz, Antimicrobial food packaging film based on the release of LAE from EVOH, International Journal of Food Microbiology, 157 (2012) 239-244.

[6] S. Bansal, S. Choudhary, M. Sharma, S.S. Kumar, S. Lohan, V. Bhardwaj, N. Syan, S. Jyoti, Tea: A native source of antimicrobial agents, Food Research International, 53 (2013) 568-584.

[7] P.M. Davidson, J.N. Sofos, A.L. Branen, Antimicrobials in Food, Third Edition, Taylor \& Francis, 2005.

[8] Y. Hara, Green tea. Health benefits and applications, Taylor \& Francis, 2001.

[9] C. Lopez-de-Dicastillo, D. Pezo, C. Nerin, G. Lopez-Carballo, R. Catala, R. Gavara, P. HernandezMunoz, Reducing Oxidation of Foods Through Antioxidant Active Packaging Based on Ethyl Vinyl Alcohol and Natural Flavonoids, Packaging Technology and Science, 25 (2012) 457-466.

[10] R. Wang, W. Zhou, R.-a.H. Wen, Kinetic Study of the Thermal Stability of Tea Catechins in Aqueous Systems Using a Microwave Reactor, Journal of Agricultural and Food Chemistry, 54 (2006) 5924-5932.
[11] G. Klein, C. Rueben, M. Upmann, Antimicrobial Activity of Essential Oil Components Against Potential Food Spoilage Microorganisms, Current Microbiology, 67 (2013) 200-208.

[12] K. Moore-Neibel, C. Gerber, J. Patel, M. Friedman, D. Jaroni, S. Ravishankar, Antimicrobial activity of oregano oil against antibiotic-resistant Salmonella enterica on organic leafy greens at varying exposure times and storage temperatures, Food Microbiology, 34 (2013) 123-129.

[13] T. Kulisic, A. Radonic, V. Katalinic, M. Milos, Use of different methods for testing antioxidative activity of oregano essential oil, Food Chemistry, 85 (2004) 633-640.

[14] R. Amorati, M.C. Foti, L. Valgimigli, Antioxidant Activity of Essential Oils, Journal of Agricultural and Food Chemistry, 61 (2013) 1083510847.

[15] R. Efrati, M. Natan, A. Pelah, A. Haberer, E. Banin, A. Dotan, A. Ophir, The combined effect of additives and processing on the thermal stability and controlled release of essential oils in antimicrobial films, Journal of Applied Polymer Science, 131 (2014) n/a-n/a.

[16] V. Muriel-Galet, J.P. Cerisuelo, G. Lopez-Carballo, M. Lara, R. Gavara, P. Hernandez- Munoz, Development of antimicrobial films for microbiological control of packaged salad, International Journal of Food Microbiology, 157 (2012) 195-201.

[17] Y. Okada, M. Okada, Scavenging effect of water soluble proteins in broad beans on free radicals and active oxygen species, Journal of Agricultural and Food Chemistry, 46 (1998) 401- 406.

[18] V. Muriel-Galet, G. López-Carballo, P. Hernández-Muñoz, R. Gavara, Characterization of ethylene-vinyl alcohol copolymer containing lauril arginate (LAE) as material for active antimicrobial food packaging, Food Packaging and Shelf Life, 1 (2014) 10-18.

[19] C. Lopez-de-Dicastillo, J. Gomez-Estaca, R. Catala, R. Gavara, P. Hernandez-Munoz, Active antioxidant packaging films: Development and effect on lipid stability of brined sardines, Food 
Chemistry, 131 (2012) 1376-1384.

[20] C. Lopez-de-Dicastillo, J.M. Alonso, R. Catala, R. Gavara, P. Hernandez-Munoz, Improving the Antioxidant Protection of Packaged Food by Incorporating Natural Flavonoids into EthyleneVinyl Alcohol Copolymer (EVOH) Films, Journal of Agricultural and Food Chemistry, 58 (2010) 10958-10964.

[21] Chemspider, CSID:21105867, http://www. chemspider.com/Chemical-Structure.21105867. html (accessed 10:18, May 9, 2014), in, 2014.

[22] Chemspider, CSID:2424, http://www.chemspider.com/Chemical-Structure.2424.html (accessed 10:13, May 9, 2014), (2014).

[23] E. Foldes, Transport of Small Molecules in Polyolefins .3. Diffusion of Topanol Ca in Ethylene Polymers, Journal of Applied Polymer Science, 51 (1994) 1581-1589.

[24] J. Brydson, Plastics Materials 7th ed., Butterworth-Heinemann; 7 edition (November 22, 1999), 2008.

[25] S. Aucejo, C. Marco, R. Gavara, Water effect on the morphology of EVOH copolymers, Journal of Applied Polymer Science, 74 (1999) 12011206.

[26] J.P. Cerisuelo, V. Muriel-Galet, J.M. Bermúdez, S. Aucejo, R. Catalá, R. Gavara, P. Hernández-Muñoz, Mathematical model to describe the release of an antimicrobial agent from an active package constituted by carvacrol in a hydrophilic EVOH coating on a PP film, Journal of Food Engineering, 110 (2012) 26-37.

[27] C. Lopez de Dicastillo, C. Nerin, P. Alfaro, R. Catala, R. Gavara, P. Hernandez-Munoz, Development of New Antioxidant Active Packaging Films Based on Ethylene Vinyl Alcohol Copolymer (EVOH) and Green Tea Extract, Journal of Agricultural and Food Chemistry, 59 (2011) 78327840.

[28] J. Anissi, M. El Hassouni, A. Ouardaoui, K. Sendide, A comparative study of the antioxidant scavenging activity of green tea, black tea and coffee extracts: A kinetic approach, Food Chemistry, 150 (2014) 438-447.
[29] S. Burt, Essential oils: their antibacterial properties and potential appliations in foods - a review, International Journal of Food Microbiology, 94 (2004) 223-253.

[30] J. Gutierrez, C. Barry-Ryan, P. Bourke, The antimicrobial efficacy of plant essential oil combinations and interactions with food ingredients, International Journal of Food Microbiology, 124 (2008) 91-97.

[31] H.J.D. Dorman, S.G. Deans, Antimicrobial agents from plants: antibacterial activity of plant volatile oils, Journal of Applied Microbiology, 88 (2000) 308-316.

[32] M. Oussalah, S. Caillet, M. Lacroix, Mechanism of action of Spanish oregano, Chinese cinnamon, and savory essential oils against cell membranes and walls of Escherichia coli 0157:H7 and Listeria monocytogenes, Journal of Food Protection, 69 (2006) 1046-1055.

[33] A. Ben Arfa, S. Combes, L. Preziosi-Belloy, N. Gontard, P. Chalier, Antimicrobial activity of carvacrol related to its chemical structure, Letters in Applied Microbiology, 43 (2006) 149-154.

[34] A. Nostro, A. Marino, A.R. Blanco, L. Cellini, M. Di Giulio, F. Pizzimenti, A.S. Roccaro, G. Bisignano, In vitro activity of carvacrol against staphylococcal preformed biofilm by liquid and vapour contact, Journal of Medical Microbiology, 58 (2009) 791-797.

[35] P.W. Taylor, J.M.T. Hamilton-Miller, P.D. Stapleton, Antimicrobial properties of green tea catechins, Food Science and Technology Bulletin: Functional Foods, 2 (2005) 71-81.

[36] J.P.E. Spencer, H. Schroeter, G. Kuhnle, S.K.S. Srai, R.M. Tyrrell, U. Hahn, C. Rice-Evans, Epicatechin and its in vivo metabolite, 3 '-O-methyl epicatechin, protect human fibroblasts from oxidative-stress-induced cell death involving caspase-3 activation, Biochemical Journal, 354 (2001) 493-500. 


\section{CHAPTER IV.}

\section{DEVELOPMENT OF}

ANTIMICROBIAL FILMS BY

IMMOBILIZATION OF THE

BIOACTIVE AGENT ON THE

POLYMER SURFACE

\section{ARTICLE 8.}

COVALENT IMMOBILIZATION OF LYSOZYME ON

ETHYLENE VINYL ALCOHOL FILMS FOR NONMIGRATING ANTIMICROBIAL PACKAGING APPLICATIONS 



\section{COVALENT IMMOBILIZATION OF LYSOZYME ON ETHYLENE VINYL ALCOHOL FILMS FOR NON-MIGRATING \\ ANTIMICROBIAL PACKAGING APPLICATIONS}

Virginia Muriel-Galet ${ }^{1}$, Talbert, J.N. ${ }^{2}$, Pilar Hernández-Muñoz ${ }^{1}$, Rafael Gavara ${ }^{1}$ and Goddard, J.M.*2

Journal of Agricultural and Food Chemistry 2013. 61, 27, 6720-6727 


\section{ABSTRACT}

The objective of this study was to develop a new antimicrobial film, in which lysozyme was covalently attached onto two different ethylene vinyl alcohol copolymers (EVOH29 and EVOH44). The EVOH surface was modified with UV irradiation treatment to generate carboxylic acid groups, and lysozyme was covalently attached to the functionalized polymer surface. Surface characterization of control and modified films was performed using attenuated total reflectance Fourier transform infrared spectroscopy (ATR-FTIR) and dye assay. The value of protein loading after attachment on the surface was $8.49 \mathrm{\mu g}$ protein $/ \mathrm{cm}^{2}$ and $5.74 \mathrm{\mu g}$ protein/ $\mathrm{cm}^{2}$ for EVOH29 and EVOH44, respectively, after 10 min UV irradiation and bioconjugation. The efficacy of the EVOH-lysozyme films was assessed using Micrococcus lysodeikticus. The antimicrobial activity of the films was tested against Listeria monocytogenes was similar to an equivalent amount of free enzyme. The reduction was $1.08 \mathrm{log}$ for EVOH29-lysozyme, 0.95 log for EVOH44-lysozyme, and 1.34 log for free lysozyme. This work confirmed the successful use of lysozyme immobilization on the EVOH surface for antimicrobial packaging.

Keywords: Lysozyme, EVOH, Immobilization, UV irradiation, L. monocytogenes 


\section{INTRODUCTION}

Microbial growth in packaged foods represents not only a significant food safety concern, but also contributes to the increasing amount of food wasted due to microbial spoilage organisms. Antimicrobials may therefore be used in food products to inhibit or retard microbial growth in foods in order to extend product shelf life [1]. When they are added directly to food formulations, antimicrobial agents cause an immediate reduction in the bacterial populations; however, this immediate activity is often followed by a decline in activity when the concentrations of active antimicrobials decreases to values below the minimal inhibitory concentration due to degradation, interaction with food or dispersion in the food matrix. Further, antimicrobial agents may exert only limited activity against injured cells or against the growth of surviving cells [2]. Many products are subject to microbial contamination at the food surface [3], and therefore, the bulk addition of antimicrobials to such foods may be excessive to achieve the desired control. An alternative is to develop an antimicrobial active packaging system by incorporation of antimicrobial agents either throughout the bulk of the packaging material to enable controlled release of the active agent or by immobilization onto the packaging surface to provide a direct contact of the antimicrobial with the food surface. A broad range of natural compounds have been researched as antimicrobial agents for use in food packaging, such as organic acids, essential oils, peptides, enzymes, etc [4].

The incorporation of antimicrobials throughout the bulk of packaging matrices has been used to control microbial contamination by allowing for diffusion of the antimicrobial through the packaging in a time-released manner [5]. Many approaches to antimicrobial active packaging follow this approach, yet it suffers certain drawbacks: a) it is often difficult to release these antimicrobials in a controlled way to maintain the antimicrobial activity; b) the presence of the agents in the polymer matrix may lead to changes in the functional properties of the films; and c) biologic antimicrobials such as peptides and enzymes are difficult to incorporate into many packaging films due to incompatibility with the film manufacturing process (thermomechanical stress or solvent miscibility). There would therefore be both functional and regulatory advantages in an antimicrobial packaging material in which the active agent is covalently bound onto the materials surface such that it was unlikely to migrate into the food [6-8]. Modification of film surfaces by chemical or physical means followed by covalent conjugation have been used for attachment of active agents that are active when in contact with foods, yet do not migrate and are not consumed [9-13].

Lysozyme is an antimicrobial enzyme and is one of the most studied natural antimicrobial agents with packaging applications [1]. It is classified as GRAS (Generally Recognized as Safe) by the Food and Drug Administration (FDA) and as a food additive by the European Union (E 1105) with bacteriostatic, bacteriolytic and bactericidal activity [14]. It is characterized by a single polypeptide chain. The antimicrobial activity depends on the ability to hydrolyze the beta 1-4 glycosidic bonds between $\mathrm{N}$-acetylmuramic acid and $\mathrm{N}$-acetylglucosamine. These bonds are present in peptidoglycans, which comprise the $90 \%$ of Gram positive bacteria cell wall, making them very susceptible to lysozyme anti- 
microbial activity [15]. Lysozyme has been immobilized on different support using entrapment, adsorption, and surface conjugation methods $[10,16]$. However, the use of covalently immobilized lysozyme as an antimicrobial agent for food packaging applications is limited.

Ethylene-vinyl alcohol (EVOH) copolymers are approved for food contact and have been used as matrices for the development of active packaging systems. EVOH has also been shown to be heat sealable, and can be used to coat active agents onto another polymer support film (e.g. polyethylene, polypropylene) [17-21]. These copolymers are also good candidates for surface modification due to the presence of hydroxyl groups. Given the applicability of EVOH films for food packaging applications, the antimicrobial nature of lysozyme, and the limitations of current immobilization methods, the objective of this study was to develop a new antimicrobial packaging film based on the covalent attachment of lysozyme to the surface of EVOH films.

\section{MATERIALS AND METHODS}

\subsection{Materials}

Films of ethylene vinyl alcohol (EVOH) copolymers (75 $\mu$ m thick) with a 29\% ethylene molar content (EVOH29) and with a 44\% ethylene molar content (EVOH44) were kindly provided by The Nippon Synthetic Chemical Company (Osaka, Japan). Lysozyme, from chicken egg white, as lyophilized powder, $\geq 98 \%$, with about 50,000 U of protein per mg, and Micrococcus lysodeikticus, ATCC 4698, were purchased from Sigma-Aldrich (St. Louis, Mo.) Listeria monocytogenes (LM 21) FSL-J1-048 was obtained from M. Wiedmann, Cornell University.

\subsection{Film preparation}

EVOH films were cut to $1 \times 2 \mathrm{~cm}^{2}$ pieces and were sequentially cleaned by sonication in isopropyl alcohol, acetone, and deionized water (10 min per repetition). The cleaned EVOH were dried overnight over anhydrous calcium sulfate at room temperature $\left(25^{\circ} \mathrm{C}\right)$.

\subsection{Surface modification}

\subsubsection{UV irradiation}

EVOH films were irradiated, after a 5-min lamp warm-up period, in an open glass Petri dish for 1, 5, 10 and $15 \mathrm{~min}$ in a Jelight Co. model 42 UVO Cleaner (Irvine, CA), which emits $28 \mathrm{~mW} / \mathrm{cm}^{2}$ light at $254 \mathrm{~nm}$ at a distance of $2 \mathrm{~cm}$. After the treatment, the films were turned over and the other sides were exposed to UV light under the same conditions. This method was used to oxidize and create carboxylic acid functional groups on both film surfaces.

\subsubsection{Bioconjugation}

Immediately after UV treatment, a conjugation solution was prepared with $5 \times 10^{-2}$ $M$ 1-ethyl-3-(3-dimethylaminopropyl) carbodiimide (EDC) (ProteoChem, Inc. Denver, Co) and 5 X 10 $10^{-3} \mathrm{M}$ N-hydroxysuccinimide (NHS) (Fisher Scientific, Pittburgh, PA) in 0.1 M pH 5.2 2-(N-morpholino) ethanesulfonic (MES) (Fisher Scientific, Pittburgh, PA) buffer (Figure 1). Concentrations re- 
present molar excesses of 100x and 10x for EDC and NHS, respectively, compared to the determined mole quantity of surface carboxylic acid groups. EVOH films $\left(4 \mathrm{~cm}^{2}\right)$ $\mathrm{mL}$ ) were shaken in the MES conjugation buffer for 30 min at room temperature (ca. $\left.25^{\circ} \mathrm{C}\right)$. After that films $\left(4 \mathrm{~cm}^{2} / \mathrm{mL}\right)$ were placed in 0.1 M pH 7.0 MES buffer to which lysozyme was added to get a final enzyme concentration of $1 \mathrm{mg} / \mathrm{mL}$. Films were agitated in lysozyme solution for $2 \mathrm{~h}$ at room temperature, rinsed in copious amounts of deionized water and dried with purified air.

\subsection{Surface analysis}

\subsubsection{FTIR analysis}

The surface modification was studied by using ATR-FTIR spectroscopy before and after the bioconjugation on an IRPrestige-21 FTIR spectrometer (Shimadzu Scientific Instruments, Inc., Kyoto, Japan) with sample compartments and a diamond ATR crystal. Each absorbance spectrum represents 32 scans at a $4 \mathrm{~cm}^{-1}$ resolution using HappGenzel apodization, taken against a background spectrum of an empty ATR crystal. The resultant spectra were analyzed with KnowItAll Informatics System 8.1 (BioRad, Hercules, CA) and processed with SigmaPlot 12.0 (Systat Software, Inc., Chicago, IL).

\subsubsection{Quantification of surface carboxylic acids}

Toluidine blue $\mathrm{O}$ (TBO) (Fisher Scientific, Pittsburgh, PA) dye assay was used to quantify the number of available carboxylic acids according to the method described by Kang et al. [22] and Uchida et al. [23] with some modifications. TBO solution $(0.5 \mathrm{mM})$ was made in deionized water and the $\mathrm{pH}$ adjusted to 10.0 with $\mathrm{NaOH}$. Control and UV-treatment films were immersed in the TBO solution and shaken for 2 $h$ at room temperature $\left(25^{\circ} \mathrm{C}\right)$. Then, the films were rinsed 3 times with deionized water adjusted to $\mathrm{pH} 10.0$ with $\mathrm{NaOH}$ to remove non-complexed dye. To desorb the complexed dye on film surfaces, films were submerged in $50 \mathrm{wt} \%$ acetic acid solution for $15 \mathrm{~min}$. Absorbances of the acetic acid solutions were measured at $633 \mathrm{~nm}$ using a Synergy 2 microplate reader (BioTek Instruments, Winooski, VT) and compared with a standard curve made of TBO dye in 50 wt\% acetic acid solution.

\subsubsection{Analysis of protein loading on films}

Lysozyme immobilized on the surface of EVOH films was quantified using a modified version of the bicinchoninic acid assay (BCA, limit of detection (LOD) of $0.5 \mathrm{\mu g}$ /



Figure 1. Scheme of the functionalization process: Surface modification of EVOH and subsequent carbodiimide-mediated conjugation of lysozyme. 
mL). In brief, each film was submerged in $3 \mathrm{~mL}$ of BCA (Thermo Scientific, Rockford, IL) working reagent and shaken for $30 \mathrm{~min}$ at $60{ }^{\circ} \mathrm{C}$. Absorbances of developed color were measured at $562 \mathrm{~nm}$ [24, 25] using a Synergy 2 microplate reader (BioTek Instruments, Winooski, VT) and a standard curve of bovine serum albumin was used to calculate protein mass per film sample area.

\subsection{Antimicrobial activity}

\subsubsection{Lysozyme effectiveness assay}

Micrococcus lysodeikticus (Sigma-Aldrich, St. Louis, Mo) was used to assess the activity of free and immobilized lysozyme [7, 10, 26]. The antimicrobial efficacy of free and immobilized lysozyme was determined by the hydrolysis of M. lysodeikticus according to the method described by Shugar [27]. The LOD from lysozyme with $M$. lysodeikticus is $5 \mu \mathrm{g} / \mathrm{mL}$. Briefly, a decrease in absorbance at $450 \mathrm{~nm}$ of a solution of $\mathrm{M}$. lysodeikticus in buffer corresponds to antimicrobial activity. The reaction mixture was prepared by suspending $9 \mathrm{mg}$ of dried M. lysodeikticus cell in $25 \mathrm{~mL}$ of $0.1 \mathrm{M}$ potassium phosphate buffer, pH 7.0, which was diluted to a final volume of $30 \mathrm{~mL}$ with the same buffer. For the free enzyme control, $100 \mu \mathrm{g}$ of free lysozyme was kept in contact with $3 \mathrm{~mL}$ of suspended lyophilized M. lysodeikticus and shaken until a constant absorbance value was reached. This amount of free lysozyme was selected since it is in the range of bonded lysozyme on the treated film surface $(96 \mu \mathrm{g}$ on a total surface area of $4 \mathrm{~cm}^{2}$ of film). Separately, three pieces of EVOH-lysozyme immobilized films (EVOH29 and EVOH44, $4 \mathrm{~cm}^{2}$ per film considering both sides of a $1 \times 2 \mathrm{~cm}^{2}$ film) were placed in a glass tube containing $3 \mathrm{~mL}$ of suspended lyophilized M. lysodeikticus and shaken until a constant absorbance value was reached (ca. two hours). The antimicrobial efficacy of each substrate was determined by monito- ring the decrease of absorbance at $450 \mathrm{~nm}$ (BioTek Instruments, Winooski, VT), and extrapolating the linear rate to determine the unit activity per gram of protein. One unit produced a change in absorbance at $450 \mathrm{~nm}$ of 0.001 per minute at pH 7.0 at $25^{\circ} \mathrm{C}$ using $\mathrm{M}$. lysodeikticus as substrate, in a $3 \mathrm{~mL}$ suspension mixture. EVOH films treated for 10 minutes by UV irradiation was chosen as the optimal sample and used for this antimicrobial assay. Native EVOH substrates were also tested as controls. Each test was performed in triplicate.

\subsubsection{Bacterial cultures}

Listeria monocytogenes (LM 21) FSL-J1-048 was obtained from M. Wiedmann, Cornell University. L. monocytogenes was selected as a model microorganism to demonstrate antimicrobial activity of the immobilized lysozyme films because it is a Gram positive bacterium and with relevance to food safety. The strain was stored in Tryptone Soy Broth (TSB) with 20\% glycerol at -80 ${ }^{\circ} \mathrm{C}$ until needed. For experimental use, the stock was maintained by monthly subculture at $4{ }^{\circ} \mathrm{C}$ on slants of Tryptone Soy Agar (TSA). To obtain early stationary phase cells, a loopful of strain was transferred to $10 \mathrm{~mL}$ of TSB and incubated at $37^{\circ} \mathrm{C}$ for 18 h, prior to each experiment.

\subsubsection{Determination of MIC against L. mo- nocytogenes.}

The lowest concentration that inhibited the growth of the pathogen microorganism was reported as the minimum inhibitory concentration (MIC) [20]. $100 \mu \mathrm{L}$ of cell cultures of L. monocytogenes in stationary phase, with an optical density of 0.9 at $600 \mathrm{~nm}$, were diluted in $10 \mathrm{~mL}$ TSB and incubated at $37^{\circ} \mathrm{C}$ for $4 \mathrm{~h}$ until exponential phase was reached, corresponding to an optical density of 0.2 at $600 \mathrm{~nm}\left(10^{5}\right.$ CFU/mL) measured with a UV-Vis spectrophotometer using TSB as blank. $100 \mu \mathrm{L}$ of exponential phase cells were inoculated 
in tubes with $10 \mathrm{~mL}$ of TSB and $100 \mu \mathrm{L}$ of Lysozyme solutions at concentration ranging between 100 and $800 \mu \mathrm{g} / \mathrm{mL}$. A control tube without lysozyme was used as a blank. Turbidity was measured after $24 \mathrm{~h}$ of incubation. A volume of $100 \mu \mathrm{L}$ of those tubes in which there was no growth after $24 \mathrm{~h}$ of incubation was inoculated on solid medium TSA to differentiate the MIC. Tests were performed in triplicate [28].

\subsubsection{Antimicrobial activity of EVOH films with lysozyme.}

Antimicrobial activity of EVOH films with lysozyme was tested in liquid media. 100 $\mu \mathrm{L}$ of exponential phase microorganism (cultured as previously described) was inoculated into tubes with $10 \mathrm{~mL}$ of TSB. Ten films (cut into pieces of $1 \times 2 \mathrm{~cm}^{2}$ ) were placed in a glass tube containing $10 \mathrm{~mL}$ of TSB. The same amount of free lysozyme (340 $\mu \mathrm{g} / \mathrm{mL}$ ) was added to additional glass tubes with $10 \mathrm{~mL}$ TSB. Tubes were incubated with rotation at $37^{\circ} \mathrm{C}$ for $24 \mathrm{~h}$. Depending on the turbidity of the tubes, serial dilutions with peptone water were made and plated on TSA. Colonies were counted after incubation at $37^{\circ} \mathrm{C}$ for $18 \mathrm{~h}$. Results were expressed as log CFU/mL. All experiments were performed in triplicate. Tubes without films served as controls. Previously controls of EVOH films, EVOH films after UV treatment and EVOH films exposed to lysozyme without UV treatment were performed and determined to exhibit no antimicrobial activity.

\subsection{Migration testing}

A test was conducted to assure that lysozyme was not released from the film into liquid media. EVOH29-lysozyme and EVOH44-lysozyme were placed in a set of glass tube containing $3 \mathrm{~mL}$ of distilled water at room temperature and shaken for $2 \mathrm{~h}$. The amount of protein in the rinse water, as well as the antimicrobial activity of the rinse water, were determined at different time intervals by sampling and analysis through the BCA and M. lysodeikticus assays as described above. The experiments were performed in triplicate.

\subsection{Statistical analysis}

One-way analyses of variance were carried out using the SPSS $® 19$ computer program (SPSS Inc., Chicago, IL, USA). Differences in pairs of mean values were evaluated by the Tukey test for a confidence interval of $95 \%$. Data are represented as mean \pm standard deviation.

\section{RESULTS AND DISCUSSION}

As reported above, the aim of this work is to develop antimicrobial packaging materials in which lysozyme is covalently immobilized onto the surface of a polymer packaging film. A two-step procedure was carried out to attach the lysozyme (Figure 1). In the first step, EVOH was exposed to UV irradiation to generate carboxylic acids. In the second step, lysozyme was covalently attached via EDC/NHS. The surface characterization was studied with ATR-FTIR and dye assay before and after the bioconjugation. The antimicrobial efficiency of the EVOH/lysozyme films was assessed against Gram positive bacteria M. lysodeikticus and L. monocytogenes. 


\subsection{Surface analysis}

\subsubsection{Surface modification of EVOH films}

UV oxidation was used to modify the surface of EVOH films and produce primarily carboxylic acid onto the surface $[29,30]$. Following UV oxidation, ATR-FTIR was used to evaluate the changes in the polymer surface. As figure 2 shows, a new absorbance band at $1700-1725 \mathrm{~cm}^{-1}$ appeared after oxidation which is attributable to the introduction of carboxylic acid groups. An increase in the number of carboxylic acids (increment in absorbance at 1700-1725 $\mathrm{cm}^{-1}$ ) was observed with increasing the duration of the UV treatment. A qualitative comparison between films shows that the number of carboxylic acids available at the EVOH29 surface was higher than that at the EVOH44 surface (Figure 2A and 2B). EVOH copolymers are composed of two segment chains: one with hydrophilic behavior, because of the hydroxyl substituent, and the other one with hydrophobic character, coming from ethylene. EVOH29 and EVOH44 contain 29\% mol and 44\% mol ethylene, respectively. As hydroxyl groups are more susceptible to oxidation, a higher mol percentage of alcohol segments in EVOH29 (which has a higher mol percentage of hydroxyl substituent monomer than EVOH44) resulted in a higher amount of carboxylic acid on the polymer surface after UV irradiation.

\subsubsection{Quantification of surface carboxylic acids}

The TBO assay was used to quantify the amount of carboxyl groups on the surface of the EVOH29 and EVOH44 films (Figure 3). A high value was observed in the EVOH29 control samples, which would not be expected to contain surface carboxylic acid groups. It is known that EVOH copolymers are obtained by hydrolysis of ethylene-vinyl acetate copolymer and that as the molar percentage of acetate groups increases the degree of hydrolysis decreases. Therefore, this initial carboxylic acid value obtained by the TBO assay may be caused by the presence of acetate substituents. The values for both films significantly increased with the length of the treatment in both films. However, the carboxylic acid values observed for EVOH29 films after 10 and 15 min of UV treatment were not significantly different $(p>0.05)$, resulting in 70.35 and $75.54 \mathrm{nmol} / \mathrm{cm}^{2}$ respectively. A similar trend was seen for the EVOH44 samples, with values of 37.43 and $47.50 \mathrm{nmol} / \mathrm{cm}^{2}$ after 10 and $15 \mathrm{~min}$ of treatment respectively. The results in-



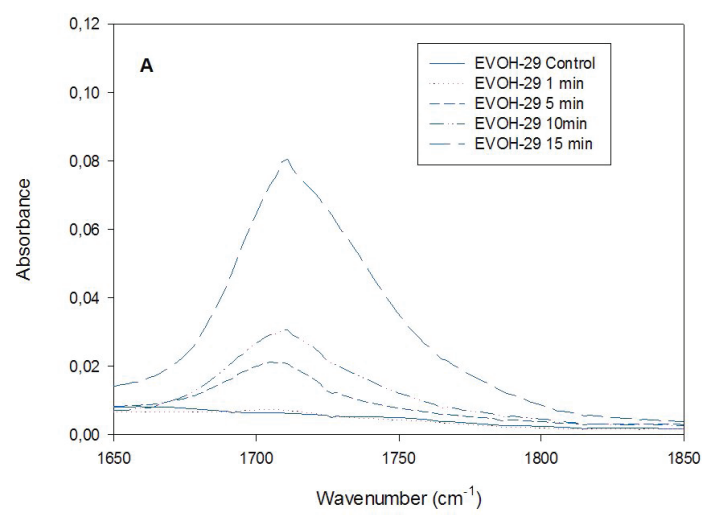
Figure 2. ATR-FTIR spectra of UV-treated EVOH29 (A) and EVOH44 (B) films in the 1650 to 1850
$\mathrm{~cm}^{-1}$ range. Spectra shown here are representative of four replicates collected from three independent films per treatment (control, 1, 5, 10 and $15 \mathrm{~min}$ ). 


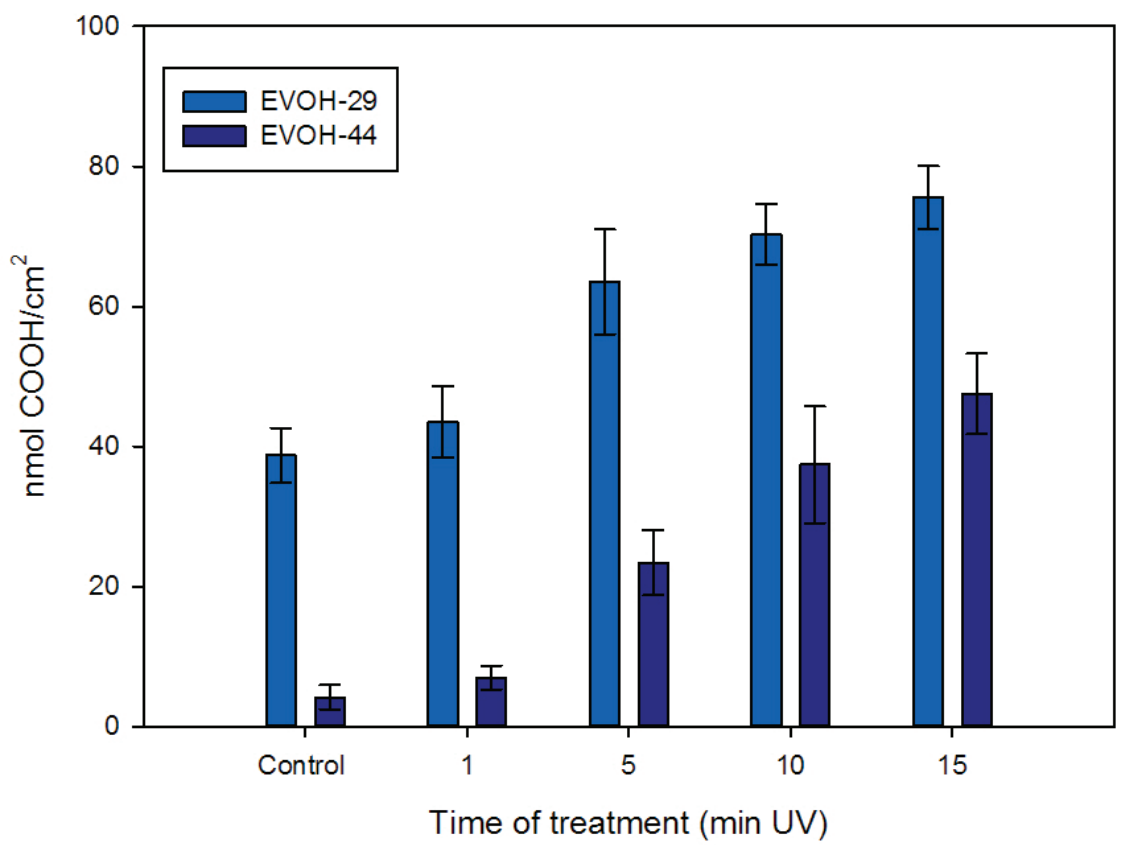

Figure 3. Available carboxylic acids surface density values obtained from TBO assay. Values are means and standard deviation of four independent films conducted on different days $(n=8)$

dicate that there were significantly more carboxyl groups on the EVOH29 than with EVOH44, which verifies the qualitative data observed with FTIR. It is likely that the EVOH29 copolymer had more carboxylic acids after UV irradiation than the EVOH44 copolymer due to the greater mol percentage of vinyl acetate monomers present in the copolymer. An increase in carboxylic acid density is valuable in that it provides a greater number of bioconjugation points for lysozyme immobilization.

\subsubsection{Lysozyme attachment to modified films}

Lysozyme was covalently attached to oxidized EVOH films using carbodiimide chemistry. The isoelectric point of the enzyme $(\mathrm{pI}=11.35)$ promotes association with the negatively charged modified film surface under conjugation conditions ( $\mathrm{pH}$ 7.0) while the EDC/NHS results in covalent attachment. After bioconjugation, ATR-FTIR spectroscopy was performed to evaluate the surface chemistry changes. Figure 4 shows the ATR-FTIR spectra of UV-treated films after the lysozyme immobilization step. Films after 1 min UV treatment were not tested as this short treatment time resulted in no significant increase in the number of carboxylic acids (Figure 3). As can be seen, a new absorption band appeared at 1550-1650 $\mathrm{cm}^{-1}$ for both EVOH films which was not present before the lysozyme addition (see Figure 2A and Figure $2 \mathrm{~B}$ ). These bands correspond to the primary and secondary amine groups of the enzyme, indicating that the lysozyme was successfully attached to the EVOH29 and EVOH44 film surfaces. The increase in absorbance at 1550-1650 $\mathrm{cm}^{-1}$ of lysozyme immobilized onto films exposed to increasing lengths of UV exposure also suggest that the amount of lysozyme immobilized increases with the density of carboxyl groups formed in film surface. 

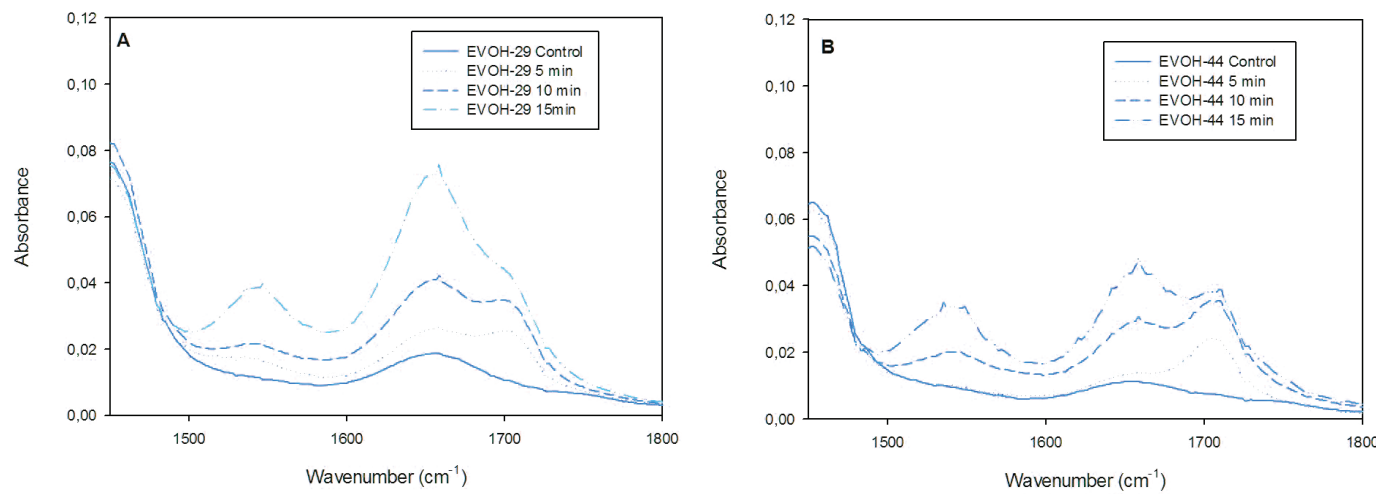

Figure 4. ATR-FTIR spectral of UV-treated films of EVOH29 (A) and EVOH44 (B) after the lysozyme immobilization step in the 1400 to $1800 \mathrm{~cm}^{-1}$ range. Spectra shown are representative of four replications collected from three independent films per UV treatment (control, 5, 10 and 15 min).

\subsubsection{Analysis of protein loading on films}

The BCA assay was performed to quantify the amount of protein on the surface of the EVOH29 and EVOH44 films. The data presented in Figure 5 for both EVOH29 and EVOH44 showed significant increases in attached protein loading with the length of UV treatment. However, no significant differences in the amount of lysozyme immobilized could be observed between
EVOH29 samples UV-treated for 10 and 15 min (8.49 and $9.69 \mu \mathrm{mg}$ protein $/ \mathrm{cm}^{2}$ respectively), in good agreement with the results of carboxylic surface density. We hypothesize that in general, the amount of protein covalently linked to the surface increases with the number of $\mathrm{COOH}$ groups. However, it is likely that there is a maximum protein immobilization density that can be achieved, beyond which the anchorage of protein molecules to the polymer surface

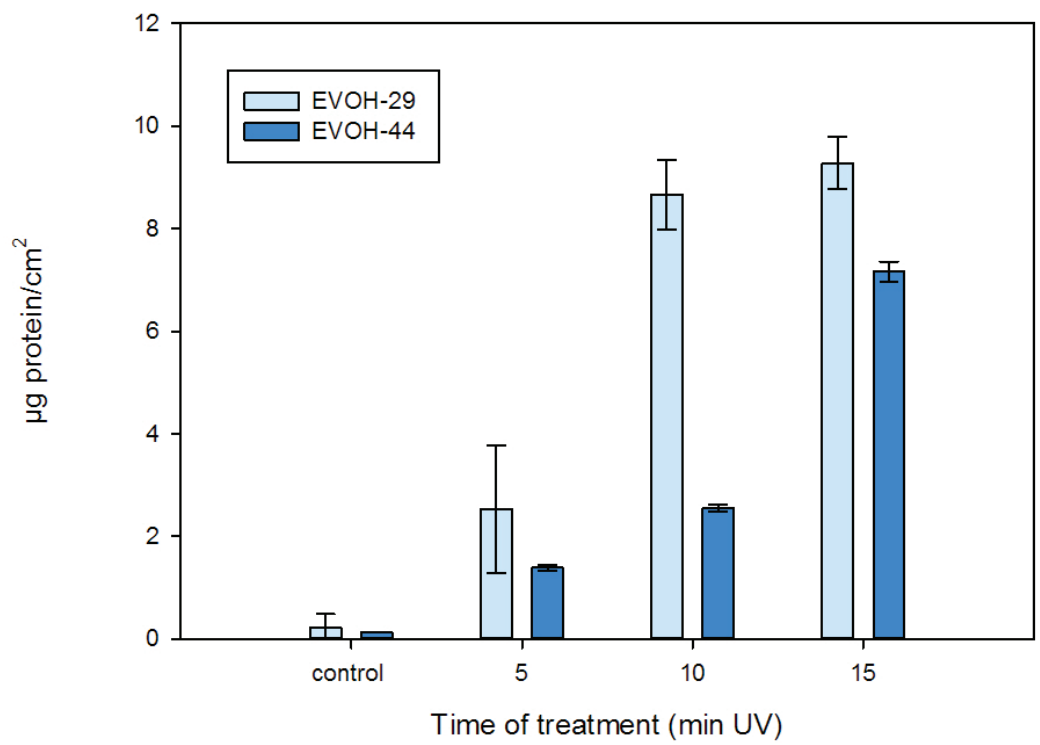

Figure 5. Protein concentration on film surface according to the BCA assay. Values are means of four independent films conducted on different days $(n=8, \pm S D)$ 
can restrict the access of other molecules to free $\mathrm{COOH}$ substituents by steric hindrance. This effect may explain the observation that while 15 minutes UV irradiation on EVOH29 samples resulted in an increase in $\mathrm{COOH}$ groups, it did not further increase the amount of immobilized protein. These results confirmed the successful lysozyme immobilization on the surface of EVOH films. Moreover, the release test confirmed that no protein was found in the liquid media (data not shown), indicating that the enzyme was strongly attached to the polymer and therefore enzyme molecules are unlikely to migrate into the solution.

\subsection{Antimicrobial activity}

\subsubsection{Efficacy of free and immobilized lyso- zyme against $M$. lysodeikticus}

Free lysozyme, as well as EVOH29 and EVOH44 films to which lysozyme was covalently attached, were put in contact with a suspension of M. lysodeikticus to quantify enzyme activity. For free enzyme activity assays, $100 \mu \mathrm{mg}$ lysozyme was added to 3
mL of suspension. Three films were used in each test tube for immobilized lysozyme activity assays. At a total surface area of $12 \mathrm{~cm}^{2}$ per tube, this corresponded to 102 $\mu \mathrm{g}$ in the 3mL suspension for the EVOH29 sample (at $8.49 \mu \mathrm{g} / \mathrm{cm}^{2}$ protein) and $69 \mathrm{mg}$ in the $3 \mathrm{~mL}$ suspension for the EVOH44 sample (at $5.75 \mu \mathrm{g} / \mathrm{cm}^{2}$ protein). The decrease in absorbance of the M. lysodeikticus suspension was monitored as a function of time to quantify the antimicrobial efficacy and enzymatic activity of the films. As can be seen in Figure 6, a clear decrease in the absorbance values was detected for both EVOH films as well as for the free enzyme. The free enzyme showed a high effectiveness against M. lysodeitkticus, with an initial activity of $1.6 \times 10^{3}$ units $/ \mathrm{mg}$ of protein. Growth inhibition progressed with exposure time. The activity of lysozyme was significantly reduced following immobilization, resulting in mean activities of 120 units/mg and 125 units/mg for lysozyme immobilized on EVOH29 and EVOH44, respectively. The loss of activity can be a consequence of the denaturation of the enzyme or of limitations to subs-



Figure 6. Effectiveness of EVOH29-Lysozyme and EVOH44-Lysozyme films, 10 min UV-treatment lysozyme immobilization, against M. lysodeikticus suspension. 
trate accessibility due to orientation, steric hindrance, or diffusion limitations [31]. Nevertheless, growth inhibition progressed with exposure time to reach similar values as the free lysozyme sample. No bacterial growth inhibition was observed when testing the migration liquid media after film removal (data not shown), which indicates that the observed efficacy is the result of direct contact with the surface attached lysozyme. This is an important distinction demonstrating the non-migratory nature of this works antimicrobial packaging film. Had lysozyme released from the film to the liquid media, inhibition would have continued after film removal. Conte et al. reported that lysozyme was not released from some active surfaces, but the films were still able to act against the bacteria when the surfaces of the lysozyme films come in contact with the suspension [7].

\subsubsection{MIC of lysozyme against L. monocyto- genes}

The bactericidal effect of lysozyme against L. monocytogenes was studied in liquid media. The lowest concentration that inhibited the pathogen microorganism was reported as the Minimum Inhibitory Concentration (MIC). There are many factors that could affect the MIC value, including temperature, inoculums size, and type of microorganisms [32]. Lysozyme at concentrations of $17 \mu \mathrm{g} / \mathrm{mL}$ in TSB inhibited the growth of L. monocytogenes. The antimicrobial properties are associated with the hydrolysis of peptidoglycan in the Gram positive bacteria cell wall [33, 34]. Lysozyme is more active against Gram positive bacteria than against Gram-negative, because their cell wall is mainly composed of peptidoglycan (90\%). In the case of Gram negative organisms, they have a greater defense system and only 5-10\% of the cell wall is constituted by peptidoglycan [35]. To improve the activity of lysozyme toward Gram-negative bacteria, it can be associated with membrane destabilizing agents
[36]. This higher resistance of Gram-negative bacteria has also been observed with other antimicrobial compounds [37, 38].

\subsubsection{Antimicrobial activity of free and im- mobilized lysozyme against L. monocyto- genes}

The antimicrobial activity of the films was tested against L. monocytogenes (Table 1 and 2). As shown in Table 1 no significant differences were observed between EVOH films, EVOH films after UV treatment and EVOH films exposed to lysozyme without UV treatment.Table 2 shows that the free enzyme (34 $\mathrm{\mu g} / \mathrm{mL}$ of lysozyme) produced a reduction of $1.34 \mathrm{log}$ in $10 \mathrm{~mL}$ TSB after $24 \mathrm{~h}$ at $37^{\circ} \mathrm{C}$ compared with the inoculated TSB control. Incubation of 10 films of EVOH29-lysozyme containing a total of $340 \mu \mathrm{g}$ of immobilized enzyme in $10 \mathrm{~mL}$ TSB resulted in a 1.08 log reduction under the same conditions. Similarly, incubation of 10 films of EVOH44-lysozyme films with a total of $230 \mu \mathrm{g}$ immobilized enzyme in $10 \mathrm{~mL}$ TSB produced a 0.95 log reduction after $24 \mathrm{~h}$ at $37^{\circ} \mathrm{C}$. No significant differences were observed between the free enzyme, EVOH29-lysozyme and EVOH44lysozyme samples, which may be due to the amount of immobilized enzyme in direct contact with the microorganisms at the film/media interface being above a minimum threshold for both EVOH films. Compared to the relative efficacy of the immobilized lysozyme films against M. lysodeikticus, the antimicrobial activity of the films against L. monocytogenes was more analogous to the free enzyme. This discrepancy may be due to the size or shape of the organisms tested, the growth phase, or diffusion restrictions as a function of media viscosity.

These results indicate that EVOH-lysozyme films (in which the enzyme lysozyme is covalently immobilized on the surface of EVOH films) can be applied to reduce the growth of Gram positive bacteria (e.g. 
Table 1. Antimicrobial effectiveness of controls films against L. monocytogenes at $37^{\circ} \mathrm{C}$ expressed as logarithm of colony forming units ( $\log (\mathrm{CFU} / \mathrm{mL})$

L. monocytogenes

\begin{tabular}{rc}
\hline & Log (CFU/mL) \\
\hline Control without film & $8.92 \pm 0.08$ \\
\hline EVOH29 & $8.75 \pm 0.03$ \\
\hline EVOH44 & $8.84 \pm 0.06$ \\
\hline EVOH29-UV treatment & $8.97 \pm 0.07$ \\
\hline EVOH44-UV treatment & $8.92 \pm 0.06$ \\
\hline EVOH29-lysozyme without UV & $9.00 \pm 0.03$ \\
\hline EVOH44-lysozyme without UV & $9.00 \pm 0.02$ \\
\hline
\end{tabular}

M. lysodeikticus and L. monocytogenes) without migration of the lysozyme from the film. While there was an observed decrease in enzymatic activity after immobilization of the enzyme on the polymeric film, it is interesting to note that the immobilized enzyme films retained similar antimicrobial activity to an equivalent amount of free enzyme over a 24 hour incubation period (1.34 log reduction for free lysozyme, 1.08 log reduction for an equivalent mass of covalently immobilized lysozyme).
Table 2. Antimicrobial effectiveness against $L$. monocytogenes at $37^{\circ} \mathrm{C}$ expressed as logarithm of colony forming units ( $\log (\mathrm{CFU} / \mathrm{mL}))$ and log reduction value (LRV).

\section{L. monocytogenes}

\begin{tabular}{rcc}
\hline & Log (CFU/mL) & LRV \\
\hline Control & $9.21 \pm 0.04$ & \\
\hline Lysozyme & $7.86 \pm 0.09$ & 1.34 \\
\hline EVOH29-lysozyme & $8.13 \pm 0.10$ & 1.08 \\
\hline
\end{tabular}

The application of these films as the internal surface of a package for direct contact with a fluid product has potential to improve stability of products without the addition (or release) of preservatives. On-going research is evaluating the effectiveness of these films against real food products at both room temperature and refrigerated temperatures to better elucidate for which food products the developed antimicrobial films will be effective.

\section{Acknowledgments}

The authors acknowledge the financial support of the Spanish Ministry of Economy and Competitiveness, projects AGL2009-08776 and AGL2012-39920-C03-01, and fellowship funding for V. M-G. We gratefully acknowledge Dr. Lynne McLandsborough for use of her microbiology laboratory facilities and Luis Bastarrachea Gutierrez for technical support in the microbiology experiments. 


\section{REFERENCES}

[1] J.H. Han, Antimicrobial food packaging, Food Technology, 54 (2000) 56-65.

[2] Y.D. Chi-Zhang, K.L. Yam, M.L. Chikindas, Effective control of Listeria monocytogenes by combination of nisin formulated and slowly released into a broth system, International Journal of Food Microbiology, 90 (2004) 15-22.

[3] J.M. Goddard, J.H. Hotchkiss, Rechargeable Antimicrobial Surface Modification of Polyethylene, Journal of Food Protection, 71 (2008) 2042-2047.

[4] A. Martyn, Z. Targonski, Antimicrobial food packagings, ZYWN.-Nauk Technology, Jakosc, 17 (2010) 33-44.

[5] P. Suppakul, K. Sonneveld, S.W. Bigger, J. Miltz, Diffusion of linalool and methylchavicol from polyethylene-based antimicrobial packaging films, Lwt-Food Science and Technology, 44 (2011) 1888-1893.

[6] A.G.M. Scannell, C. Hill, R.P. Ross, S. Marx, W. Hartmeier, E.K. Arendt, Development of bioactive food packaging materials using immobilised bacteriocins Lacticin 3147 and Nisaplin (R), International Journal of Food Microbiology, 60 (2000) 241-249.

[7] A. Conte, G.G. Buonocore, M. Sinigaglia, M.A. Del Nobile, Development of immobilized lysozyme based active film, Journal of Food Engineering, 78 (2007) 741-745.

[8] Z.X. Lian, Z.S. Ma, J. Wei, H. Liu, Preparation and characterization of immobilized lysozyme and evaluation of its application in edible coatings, Process Biochemistry, 47 (2012) 201-208.

[9] L. Hao, Z. Wang, J. Qi, S. Wang, L. Hou, J. Wu, J. Yang, Preparation of Immobilized epsilon-Polylysine PET Nonwoven Fabrics and Antibacterial Activity Evaluation, Journal of Wuhan University of Technology-Materials Science Edition, 26 (2011) 675-680.

[10] A. Conte, G.G. Buonocore, A. Bevilacqua, M. Sinigaglia, M.A. Del Nobile, Immobilization of lysozyme on polyvinylalcohol films for active packaging applications, Journal of Food Protection, 69 (2006) 866-870.

[11] J.M. Goddard, J.N. Talbert, J.H. Hotchkiss, Covalent attachment of lactase to low-density polyethylene films, Journal of Food Science, 72 (2007) E36-E41.

[12] F. Tian, Decker, E.A. and Goddard, JM. Control of lipid oxidation by non-migratory active packaging films prepared by photoinitiated graft polymerization, Journal of Agricultural and Food Chemistry, 60 (31) (2012) 7710-7718.

[13] K. Mahoney, Talbert, JN, and Goddard, JM, Effect of Polyethylene glycol Tether Size and Chemistry on the Attachment of Lactase to Polyethylene Films, Journal of Applied Polymer Science, 127 (2) (2013) 1203-1210.

[14] P.M. de Souza, A. Fernandez, G. Lopez-Carballo, R. Gavara, P. Hernandez-Munoz, Modified sodium caseinate films as releasing carriers of lysozyme, Food Hydrocolloids, 24 (2010) 300-306.

[15] J.N. Losso, Nakai, S., \& Charter, E.A, Natural food antimicrobial systems, CRC Press LLC, Boca Raton (Florida), 2000.

[16] J.V. Edwards, N. Prevost, B. Condon, K. Sethumadhavan, J. Ullah, A. Bopp, Immobilization of Lysozyme on Cotton Fabrics: Synthesis, Characterization, and Activity, Aatcc Review, 11 (2011) 73-79.

[17] C.L. de Dicastillo, C. Nerin, P. Alfaro, R. Catala, R. Gavara, P. Hernandez-Munoz, Development of New Antioxidant Active Packaging Films Based on Ethylene Vinyl Alcohol Copolymer (EVOH) and Green Tea Extract, Journal of Agricultural and Food Chemistry, 59 (2011) 7832-7840.

[18] C. Lopez-de-Dicastillo, J.M. Alonso, R. Catala, R. Gavara, P. Hernandez-Munoz, Improving the Antioxidant Protection of Packaged Food by Incorporating Natural Flavonoids into Ethylene-Vinyl Alcohol Copolymer (EVOH) Films, Journal of Agricultural and Food Chemistry, 58 (2010) 10958-10964. 
[19] C. Lopez-de-Dicastillo, R. Catala, R. Gavara, P. Hernandez-Munoz, Food applications of active packaging EVOH films containing cyclodextrins for the preferential scavenging of undesirable compounds, Journal of Food Engineering, 104 (2011) 380-386.

[20] V. Muriel-Galet, G. Lopez-Carballo, R. Gavara, P. Hernandez-Munoz, Antimicrobial food packaging film based on the release of LAE from EVOH, International Journal of Food Microbiology, 157 (2012) 239-244.

[21] V. Muriel-Galet, J.P. Cerisuelo, G. LopezCarballo, M. Lara, R. Gavara, P. HernandezMunoz, Development of antimicrobial films for microbiological control of packaged salad, International Journal of Food Microbiology, 157 (2012) 195-201.

[22] E.T. Kang, K.L. Tan, K. Kato, Y. Uyama, Y. Ikada, Surface modification and functionalization of polytetrafluoroethylene films, Macromolecules, 29 (1996) 6872-6879.

[23] E. Uchida, Y. Uyama, Y. Ikada, Sorption of low-molecular-weight anions into thin polycation layers grafted onto a film Langmuir, 9 (1993) 1121-1124.

[24] A.L. Plant, L. Locasciobrown, W. Haller, R.A. Durst, Immbolization of binding-proteins on nonprorous supports-Comparison of protein loading, activity, and stability Applied Biochemistry and Biotechnology, 30 (1991) 83-98.

[25] P.K. Smith, R.I. Krohn, G.T. Hermanson, A.K. Mallia, F.H. Gartner, M.D. Provenzano, E.K. Fujimoto, N.M. Goeke, B.J. Olson, D.C. Klenk, Measurement of protein using bicinchoninic acid, Analytical Biochemistry, 150 (1985) 76-85.

[26] G.G. Buonocore, A. Conte, M.R. Corbo, M. Sinigaglia, M.A. Del Nobile, Mono- and multilaver active films containing lysozyme as antimicrobial agent, Innovative Food Science \& Emerging Technologies, 6 (2005) 459-464.

[27] D. Shugar, The measurement of Lysozyme activity and the ultra-violet inactivation of Lysozyme, Biochimica Et Biophysica Acta, 8
(1952) 302-309.

[28] M100-S18, in: Performance standards for antimicrobial susceptibility testing: Eighteenth informational supplement, Clinical and Laboratory Standards Institute, Wayne, PA, 2008.

[29] J.A. Barish, J.M. Goddard, Topographical and Chemical Characterization of Polymer Surfaces Modified by Physical and Chemical Processes, Journal of Applied Polymer Science, 120 (2011) 2863-2871.

[30] J.P. Deng, L.F. Wang, L.Y. Liu, W.T. Yang, Developments and new applications of UV-induced surface graft polymerizations, Progress in Polymer Science, 34 (2009) 156-193.

[31] J.N. Talbert, J.M. Goddard, Enzymes on material surfaces, Colloids and Surfaces BBiointerfaces, 93 (2012) 8-19.

[32] R.J.W. Lambert, Susceptibility testing: inoculum size dependency of inhibition using the Colworth MIC technique, Journal of Applied Microbiology, 89 (2000) 275-279.

[33] P.J.P. Espitia, N.D.F. Soares, J.S.D. Coimbra, N.J. de Andrade, R.S. Cruz, E.A.A. Medeiros, Bioactive Peptides: Synthesis, Properties, and Applications in the Packaging and Preservation of Food, Comprehensive Reviews in Food Science and Food Safety, 11 (2012) 187-204.

[34] B. Masschalck, D. Deckers, C.W. Michiels, Lytic and nonlytic mechanism of inactivation of Gram positive bacteria by lysozyme under atmospheric and high hydrostatic pressure, Journal of Food Protection, 65 (2002) 1916-1923.

[35] J.N. Losso, S. Nakai, E.A. Charter, Natural food antimicrobial systems, Boca Raton (Florida): CRC Press LLC, Florida 2000.

[36] A.O. Gill, R.A. Holley, Inhibition of bacterial growth on ham and bologna by lysozyme, nisin and EDTA, Food Research International, 33 (2000) 83-90.

[37] N. Canillac, A. Mourey, Antibacterial activity of the essential oil of Picea excelsa on Listeria, 
Staphylococcus aureus and coliform bacteria, Food Microbiology, 18 (2001) 261-268.

[38] S. Harpaz, L. Glatman, V. Drabkin, A. Gelman, Effects of herbal essential oils used to extend the shelf life of freshwater-reared Asian sea bass fish (Lates calcarifer), Journal of Food Protection, 66 (2003) 410-417. 


\section{GENERAL DISCUSSION}

The findings of this Doctoral Thesis which are presented in the previous four chapters all correspond to a common objective of developing and characterizing antimicrobial packaging films based on the incorporation or attachment of naturally occurring antimicrobial compounds with the purpose of inhibiting the proliferation of microorganisms and extending the shelf life of food products.

Table 1 shows a summary of the antimicrobial agents employed, the concentration added, the methodology followed for their incorporation into EVOH, the microorganisms tested and the possible food application. Ethylene vinyl alcohol copolymer (EVOH) was chosen as the basic material for the development of antimicrobial polymer systems. Since the properties of EVOH copolymers vary considerably with the ethylene content, two commercial copolymers with extreme ethylene contents (i.e. EVOH29 and EVOH44) were selected. The hydrophilic character provided by the vinyl alcohol monomer makes the polymer sensitive to water, and this sensitivity increases with increasing contents of the monomer (decreasing ethylene contents). The sensitivity to water affects the mechanical and especially the barrier properties of EVOH films, which decrease greatly in humid environments. In order to cope with this drawback, EVOH is commonly coextruded or laminated in polyolefin materials for general purpose barrier packages. However, in this dissertation, EVOH was not selected to provide an oxygen barrier but as a polymer carrier in the form of film to provide antimicrobial effects. Accordingly, two innovative methodologies were designed to produce antimicrobial EVOH films intended for active food packaging applications, in which antimicrobial compounds - oregano essential oil, citral, ethyl lauroyl arginate, epsilon-polylysine, green tea extract and lysozyme - were incorporated. One methodology is based on incorporating the active agent in the filmforming solution; after casting, the dry EVOH matrix protects the active agents during storage and triggers their release, and hence their activity, on exposure to a humid environment (the food product). An alternative methodology for creating antimicrobial films consists in immobilizing the bioactive agent on the film surface by covalent bonding. In this case, EVOH provides a suitable chemistry (hydroxyl group) for surface modification to introduce the desired quantity of reactive functional groups (carboxylic acid group) for subsequent covalent attachment of a bioactive compound to the functionalized polymer surface. 


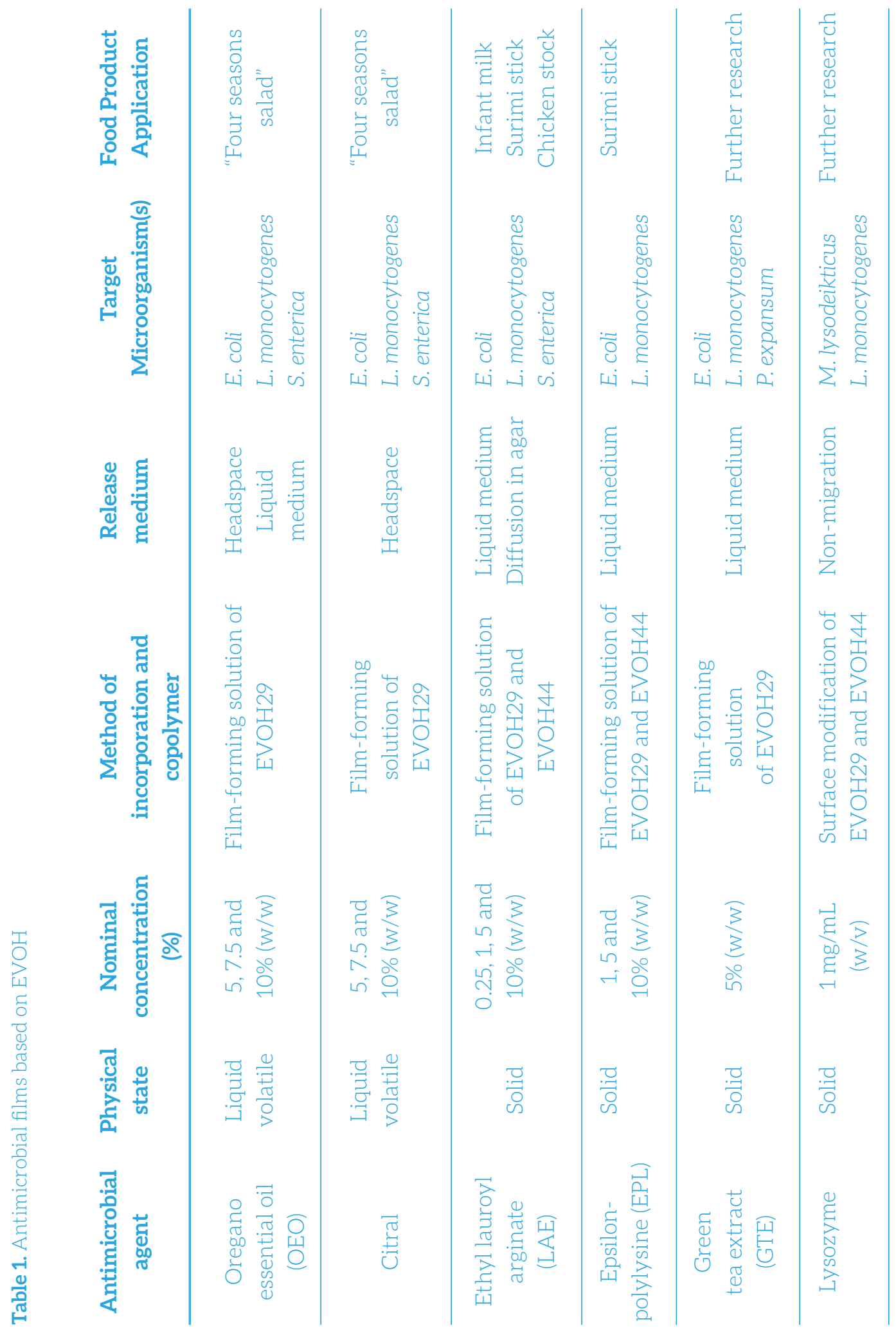


Chapter 1 examines the antimicrobial activity of EVOH29 films incorporating naturally occurring volatile compounds: oregano essential oil (OEO) and citral. The films developed were used to pack minimally processed salads, combining modified atmosphere technology (MAP) and active packaging in an attempt to extend shelf life and reduce possible microbiological risks. In the second part of the chapter the study is transferred from laboratory scale to semi-industrial scale.

Firstly, the minimum inhibitory concentrations of OEO and citral were determined in vapour phase against three pathogenic bacteria: Listeria monocytogenes, Escherichia coli and Salmonella enterica. These microorganisms were selected because they are often involved in foodborne infections and present in raw vegetables, where they arrive during growing, harvesting or postharvest handling and distribution steps [1].

OEO and citral were incorporated into the film-forming solution of EVOH29 and subsequently applied as a coating over polypropylene (PP). The EVOH29 coating had an average thickness of $3.0 \pm 0.5 \mu \mathrm{m}$. There was a partial loss of the volatile agents owing to evaporation during the coating and drying process. The loss of carvacrol, the main compound of OEO, was ca. 20\%, while citral losses reached 50\%.

Antimicrobial in vitro studies carried out in vapour phase with PP/EVOH films incorporating OEO and citral produced excellent results against the pathogenic bacteria selected, with more activity against the Gram-negative bacteria that were tested (E. coli and S. enterica). It has been demonstrated that carvacrol and citral have more affinity for the lipids of the outer membrane of Gram-negative bacteria, with the subsequent destabilization increasing the permeability of the cytoplasmic membrane and releasing ions and cellular compounds [2].

PP/EVOH antimicrobial films were used to package minimally processed salad. Regarding this type of food product, peeling, grating and shredding change minimally processed salad from a relatively stable product with a long shelf life to a perishable one that has only a short shelf life of a few days. Microbial spoilage is one of the factors that causes deterioration in products of this kind, resulting in colour degradation, texture loss and flavour changes [3]. Before packaging the salad with the antimicrobial film, it was first inoculated with the above-mentioned pathogenic microorganisms. The antimicrobial effects on the salad that were observed were lower than those obtained in in vitro studies, probably owing to agent/food matrix interactions, with subsequent loss of antimicrobial activity, and to partial sorption and diffusion of the agent in the food matrix, with a subsequent reduction of the antimicrobial concentration required in the vapour phase to ensure inhibition of microbial growth. However, the films developed provided a significant inhibition of the microbial load commonly found in salads, with a consequent extension of shelf life to 8 days. The microbial inhibition was measurable especially in the first stage of the storage period, when the concentration of the agent in the package headspace was higher and the storage temperature lower.

One factor that limits the applicability of essential oils is their impact on the odour of the food product. Therefore, sensory analyses were carried out to evaluate the odour, visual appearance and general acceptability of the salad samples. At the beginning of the storage period, the differences that the judges perceived in the odour and general acceptability of the samples depended only on the concentration of the agent (5 or 10\%) and not on the 
compound that was used (OEO or citral). Only at the end did the evaluation suggest that samples with 5\% OEO were visually preferred by the judges.

On the basis of the results obtained above - i) extension of the shelf life of minimally processed salads; ii) fresher product with better organoleptic characteristics; iii) decrease in the presence of pathogenic bacteria responsible for foodborne illness - the second part of the chapter focuses on the manufacture of active PP/EVOH films with OEO and citral in a processing plant, using gravure printing technologies, and their application to the packaging of minimally processed salad under MAP.

Industrial printing equipment was used to coat a BOPP film with the active EVOH layer that had been developed. The coating had a thickness of $1.15 \pm 0.05 \mu \mathrm{m}$ and the agent loss during the drying process was 35\% for carvacrol and 50\% for citral, similar to what occurred in the laboratory manufacture described earlier. The addition of the active EVOH coating did not noticeably affect the functional properties of the packaging substrate film, with the exception of a severe increase in the barrier properties in dry conditions. However, this effect was counteracted by the water plasticization of EVOH29 when exposed to a high-humidity environment such as that created in the interior of a bag of fresh produce. The headspace composition was measured in all the samples and, as expected, $\mathrm{O}_{2}$ was depleted and there was a corresponding increase in $\mathrm{CO}_{2}$ levels as the product breathed, without significant differences between coated and control bags, demonstrating that the presence of the coating did not influence the headspace composition during the storage period.

As mentioned previously, minimally processed salads have a reduced shelf life, the main spoilage mechanisms being initial spoilage and pathogenic microbial load, enzymatic activity and moisture loss [4, 5]. The use of the active films produced an improvement in microbial stability, especially with regard to inhibition of the growth of enterobacteria, lactic acid and psychrotrophic bacteria, and yeasts and moulds at the beginning of storage.

Sensory studies showed that release of the active agent resulted in a non-typical smell which led the judges to prefer the control samples on the first day of storage, whereas after long-term storage the samples in active bags were preferred.

From the performance analysis it can be concluded that the antimicrobial PP/EVOH films with a volatile compound produced better results throughout the storage period. The microbial count recorded for these samples was lower, they were fresher than the control samples, their overall sensory quality acceptability was marked higher than that of the control samples and they were described as having a pleasant flavour.

The potential use of EVOH films as carriers and release systems for other naturally occurring antimicrobial compounds and their effectiveness in real foods is also explored in the current dissertation. For this purpose, a second study was performed with solid antimicrobial agents, ethyl lauroyl arginate (LAE) and epsilon-polylysine (EPL), incorporated in EVOH29 and EVOH44 films, and it is reported in Chapter 2. The goal of this chapter is to evaluate the ability of EVOH films to provide continuous antimicrobial activity against the main pathogenic bacteria responsible for foodborne illness, and thus extend the microbiological shelf life of various liquid and solid foods with high water activity values. 
In the first part of the chapter, a study of the antimicrobial and functional properties of films based on EVOH29 and EVOH44 incorporating LAE is reported. LAE is one of the most potent antimicrobial agents among the new food preservatives. Before it was incorporated in EVOH films, the antimicrobial properties of LAE against the pathogenic bacteria L. monocytogenes, E. coli and S. enterica were determined. The minimal inhibitory concentrations (MIC: 7, 20, 10 ppm) and the minimal bactericidal concentrations (MBC: 12, 32, 16 ppm) of LAE against these microorganisms were determined in liquid medium and the results demonstrated that this agent is more efficient against Gram-positive bacteria.

Flow cytometry confirmed the cell damage caused by LAE, and it was observed that Gram-negative bacteria were less susceptible to the antibacterial action because they possess an outer membrane surrounding the cell wall that restricts diffusion of hydrophobic compounds through its lipopolysaccharide covering [6]. Scanning electron microscopy (SEM) was performed to investigate the LAE action mechanism. Gram-positive and Gram-negative bacteria (L. monocytogenes and E. coli) were exposed to their MBC to determine the morphological changes resulting in the membrane structure. The micrographs showed that LAE produced considerable changes in the cell envelope, confirming that membranes are the main target, producing disruption and instability of the plasma membrane without cell lysis.

Once the antimicrobial properties of LAE had been studied, the compound was added to the EVOH29 and EVOH44 film-forming solutions and the films were successfully manufactured by casting. The antimicrobial activity of the films was assessed by the agar diffusion method, and confirmed by the presence of a clear inhibition zone around the films. Films containing 5 and 10\% of LAE were also assayed for antimicrobial activity in liquid medium at $37^{\circ} \mathrm{C}$ and $4^{\circ} \mathrm{C}$. The antimicrobial activity of EVOH29 containing 5 and $10 \%$ of LAE was so high that after only 5 min of immersion in the liquid medium total inhibition of growth of L. monocytogenes, E. coli and S. enterica was achieved. In the case of EVOH44 with 5\% LAE, the growth inhibition progressed with exposure time, reaching a bactericidal effect after 90, 300 and 180 minutes against L. monocytogenes, E. coli and S. enterica, respectively. The bactericidal effect with EVOH44 and 10\% LAE was reached after 30 min against L. monocytogenes, after 180 min against E. coli and after 90 min against S. enterica. This difference between EVOH29 and EVOH44 is due to the higher hydrophilicity of EVOH29. This copolymer gains a larger amount of water, becoming severely plasticized and promoting a very fast agent release. In contrast, the diffusion of LAE in EVOH44 is slower, so that the achievement of the MBC occurs later during the exposure time.

The profiles of time-dependent release of LAE from EVOH29 and EVOH44 were studied in aqueous medium at $23{ }^{\circ} \mathrm{C}$ and $4{ }^{\circ} \mathrm{C}$. In both polymers, LAE was released in water continuously, following a profile similar to an exponential function, which tends to a maximum value. LAE was totally released from the EVOH copolymers, although the release from EVOH29 was faster at both temperatures $\left(23^{\circ} \mathrm{C}\right.$ and $\left.4{ }^{\circ} \mathrm{C}\right)$. The release from active EVOH44 films was more sustained, especially at refrigeration temperatures. These results are in agreement with the differences in the antimicrobial effect observed between the two polymers.

The optical, surface, thermal and barrier properties of the films were characterized to determine the effect of incorporating LAE on these functional properties of EVOH films as 
packaging materials. The results showed that the films were continuous and transparent and there were no important changes in their optical properties with respect to the control samples. However, the incorporation of LAE reduced the contact angle, owing to the surfactant nature of the molecule. Thermal analyses of the films revealed that in dry conditions the incorporation of the antimicrobial agent increased the intermolecular interactions, producing an antiplasticization effect, and there was an increase in the amorphous region and a deteriorated crystallinity structure with smaller crystal size. As a consequence of the smaller and more irregular crystalline phase, the barriers to water vapour and oxygen decreased.

The antimicrobial in vitro results obtained were useful to provide deeper knowledge of how EVOH29 and EVOH44 can retain LAE during film manufacture and storage and release it when they come into contact with food simulants. Next, the efficiency of the antimicrobial films was tested to ensure that the minimal inhibitory concentration of LAE was reached at the right time and was maintained throughout the shelf life of real food products. For this purpose, various food products were tested with the films that had been developed: infant milk, chicken stock and surimi sticks. They were previously inoculated with the main problematic pathogenic bacteria (L. monocytogenes, E. coli and S. enterica), and the microbial load was also determined.

The study revealed that a higher concentration of LAE is required to produce total inhibition against these pathogenic bacteria in food compared with in vitro tests, and that the efficiency of the antimicrobial films varied depending on the food matrix, being more effective in liquid food. This is related with the amount of LAE released to the medium and the release kinetics. These parameters depend on several factors, such as the water activity of the food and, consequently, the level of plasticization achieved by the film; and also the compatibility of the antimicrobial agent with the film and the food medium. A further factor to be taken into account is that in solid foods the morphological structure will also affect the diffusion of the antimicrobial agent from the surface to the centre of the matrix.

The results also demonstrated that the films developed have a great potential to be used in the design of food packages, because they can be applied as an inner coating of the packaging structure, releasing the active agent and producing great protection against contamination with an extension of the microbiological shelf life of foods. This work demonstrates that EVOH films could be used to package foods free of preservatives, ensuring their safety even after package opening at home. This packaging technology could be used as an integral part of "Hurdle Technology".

Any antimicrobial agent added to the food package for the purpose of being released into the food must be non-toxic to human health. Therefore, an in vitro gastrointestinal digestion of the food exposed to the antimicrobial films was conducted to ensure the absence of LAE. As already mentioned in the introduction, LAE degrades to N-lauroylL-arginine (LAS), and hydrolysis of it results in the production of arginine, which is converted to ornithine and urea, following acid catabolism via the urea and citric acid cycles, resulting in carbon dioxide and urea, which are excreted in the expired air and in urine, respectively [7]. 
After an in vitro gastrointestinal digestion with subsequent quantification by HPLC, LAE and LAS were not detected in any of the samples, demonstrating that the antimicrobial agent is safe and does not compromise human health.

In the second part of Chapter 2, antimicrobial films based on EVOH29 and EVOH44 incorporating epsilon-polylysine (EPL) are developed and their in vitro and in vivo activity against foodborne pathogens are assayed. Firstly, antimicrobial activity of EPL was tested before being incorporated into EVOH29 and EVOH44, and the results showed MIC values of 23 and $40 \mathrm{ppm}$, and MBC values of 70 and $90 \mathrm{ppm}$ against the pathogenic bacteria L. monocytogenes and E. coli, respectively. The antimicrobial effect of EPL is attributed to electrostatic absorption onto the cell surface of the microorganism, where it interacts with the bacterial membranes [8]. In agreement with this report, SEM images of bacteria exposed to this agent proved that there was damage to the cell membrane in both bacteria, which was more obvious in the case of L. monocytogenes, with the images showing the collapse of the bacteria.

The films with EPL were successfully developed by casting and were characterized. The films were colourless and transparent, and only at the highest EPL concentration (10\%) were there significant changes in optical properties with respect to the control samples. The amount of EPL capable of migrating from the polymer matrix was quantified, and a higher percentage of ethylene retained a greater amount of EPL.

Bacterial growth studies of L. monocytogenes and E. coli in the presence of the films were conducted at $37^{\circ} \mathrm{C}$ and $4{ }^{\circ} \mathrm{C}$. The greatest bacterial inhibition was achieved at $37^{\circ} \mathrm{C}$ and with EVOH29 films, as expected from the greater migration values. However, when working at refrigeration temperature, differences in bacterial inhibition caused by the two copolymers were less marked. The slower release of EPL at $4{ }^{\circ} \mathrm{C}$ resulted in a reduced concentration of antimicrobial in the medium, and thus a decrease in the effectiveness of the films.

Once the antimicrobial effectiveness of the EVOH films had been assessed, an in vivo study with food was carried out with the more active films. EVOH29 and EVOH44 films with 10\% of EPL were chosen to package ready-to-eat surimi sticks inoculated with pathogenic bacteria commonly detected in products of this kind, L. monocytogenes and $E$. coli $[9,10]$. In this work the microbial load of the products after opening was also studied. No growth of enterobacteriaceae was detected during the extended refrigerated storage period studied, confirming that the surimi samples were made in accordance with Good Manufacturing Practice (GMP), ensuring the quality of the products. The active films developed provided a bactericidal effect against lactic acid bacteria and total aerobic count, and the psychrotrophic and Pseudomonas counts decreased with respect to the control by the end of storage at $4{ }^{\circ} \mathrm{C}$, when the concentration of the agent on the surimi surface was higher.

The total foodborne bacteria counts of surimi wrapped with the active samples showed a significant decrease in comparison with the control sample. However, as observed before with other antimicrobial compounds, the in vivo results showed less efficiency compared with those in vitro. Higher EPL concentrations would be necessary to produce total inhibition against L. monocytogenes and E. coli. The antimicrobial activity of the films was probably reduced because of one or both of the following two reasons: a possible interac- 
tion of the antimicrobial agent with some components of the food matrix, reducing its availability to kill bacteria; a lesser surface contact between food and film, resulting in a slower release. Foods have more nutrients, lower water activity, higher salt contents, and fats or proteins that may interact with the antimicrobial agents. In addition, the release kinetics and the amount of the antimicrobial compound released to the medium change when assays are made with a solid food instead of a liquid one. Nevertheless, the films that have been developed are extremely useful because, working at a higher pathogenic bacteria level $\left(10^{5} \mathrm{CFU} / \mathrm{mL}\right)$ than that found in food products after recontamination, they still produced growth inhibition against the pathogenic bacteria.

In Chapter 3 studies on films incorporating a combination of naturally occurring antimicrobial compounds are carried out. For this purpose, liquid volatile oregano essential oil (OEO) was incorporated with green tea extract (GTE) in solid form in EVOH29 matrices. As discussed in the present dissertation, traditional packaging methods might not be sufficient to provide an extension of shelf life. Active packaging technology based on the release of a volatile antimicrobial may have some disadvantages, such as loss of the volatile antimicrobial compound during film manufacture and storage or the intense aroma that is inherently associated with these agents and that could cause an undesirable modification of the organoleptic properties of the food. In the case of the incorporation of non-volatile compounds, surface contact between food and packaging that allows migration of the compounds to the food is required; therefore its use is limited to semi-solid or liquid foods, where the contact is excellent, or to vacuum packaging of solids. In this chapter we have explored a combination of volatile and non-volatile antimicrobial compounds, an optional system that merges the beneficial antimicrobial effects of the two agents and may reduce the amount of each antimicrobial that is required in comparison with the amount needed when used alone. Furthermore, these films can be used for a larger number of foods with different characteristics, liquid, semi-solid and solid, releasing the active compounds into the food product or the surrounding headspace.

Cast films based on EVOH containing 5\% w/w of GTE, 5\% w/w of OEO and 5\% w/w of both components were manufactured. The films were all transparent and without discontinuities, and the control and OEO-containing films were colourless, while those containing GTE extract had a brownish colour. Thermal analyses demonstrated that the addition of GTE and OEO produced a slight increase in film rigidity and caused an irregular crystalline structure with more crystals of smaller size. The kinetics of the release of the main compounds of GTE (epicatechin, caffeine, catechin) and OEO (carvacrol) into three food simulants was characterized at $23^{\circ} \mathrm{C}$ and $4{ }^{\circ} \mathrm{C}$, since the release process is a key parameter for the efficiency of the active film. The simulant containing 50\% (v/v) ethanol promoted the highest and fastest release of all the compounds, owing to the higher plasticization of the polymer matrix, which resulted in faster diffusion of all the additive molecules through a more open and flexible polymer structure.

Taking advantage of the known antioxidant properties of GTE and OEO [11, 12], the antioxidant capacity of the food simulants after being exposed to each active film was determined. All the active samples were antioxidant, but the samples with GTE had double the antioxidant activity of those with $\mathrm{OEO}$, as could be expected from the high concentration of various catechins that constitute the extract. No synergistic or additive effect was found. The higher chemical compatibility of catechins and carvacrol with 50\% ethanol increased migration and, therefore, antioxidant activity. The antimicrobial activity of the 
films demonstrated that carvacrol can be released from the film into the atmosphere, and acts on microorganisms from the vapour phase, producing an antimicrobial and antifungal effect. The same films tested in liquid media were able to release carvacrol owing to the plasticization of EVOH29 in the presence of water. In the case of the samples containing GTE, activity against the pathogenic bacteria was only observed in liquid media, and this activity was lower than with OEO. As with the antioxidant activity, no synergistic effect was noticed in their antimicrobial activity.

As is described in the first three chapters, active EVOH29 and EVOH44 films manufactured by casting have potential for further development as food packaging films. In all the developments described, antimicrobial agents were easily incorporated into the film, the agent kept its activity and its release resulted in the expected antimicrobial effect. However, other antimicrobial substances such as bacteriocins or enzymes are difficult to incorporate into packaging films because of their incompatibility with the film manufacturing process (thermo-mechanical stress or solvent miscibility) [13], and their large molecular size would produce limited release. Moreover, the ideal paradigm for active packaging would be that the antimicrobial agent inhibits microbial growth without being released from the film. One solution that has been explored is the use of a technique of immobilization on the food/packaging interface. The proposal is that these films should be applied as the internal surface of a package in which direct contact between the inner layer and the food produces an improvement in microbiological food stability without the addition (or release) of additives.

Chapter 4 describes the use of EVOH copolymers as substrates for covalent attachment of lysozyme to the film surface. The purpose of this active packaging strategy is that the film exerts an antimicrobial effect by direct contact with the surface of the food product, avoiding release of the preservative to it. EVOH copolymers are good candidates for this purpose because of the presence of hydroxyl groups in their chemical structure, facilitating film surface modification prior to linkage of the antimicrobial. Accordingly, the films were exposed to UV irradiation for different times to oxidize hydroxyl groups to carboxylic acids. Infrared spectroscopy revealed that an absorbance band (1700-1725 $\mathrm{cm}^{-1}$ ) attributable to the introduction of carboxylic acid groups built up after oxidation. An increase in the number of carboxylic acids was observed with increasing duration of the UV treatment. Comparison between copolymers showed that the number of carboxylic acids available on the EVOH29 surface was higher than on EVOH44, owing to the higher mol percentage of alcohol segments. An increase in carboxylic acid density is desirable because it provides a greater number of bioconjugation points for lysozyme immobilization.

Lysozyme was covalently attached to oxidized EVOH films using carbodiimide chemistry. After immobilization, a new infrared absorption band $\left(1550-1650 \mathrm{~cm}^{-1}\right)$ was observed for both EVOH films. These bands correspond to the primary and secondary amine groups of the enzyme, indicating that the lysozyme was successfully attached to the EVOH29 and EVOH44 film surfaces. In general, the amount of protein covalently linked to the surface increases with the number of carboxylic acid groups. However, it is likely that there is a maximum protein immobilization density that can be achieved, beyond which the anchorage of protein molecules to the polymer surface would hinder access of other molecules to free carboxylic acid substituents by steric hindrance. 
The efficacy of the free enzyme and the immobilized lysozyme was tested, using a suspension of Micrococcus lysodeikticus. The decrease in absorbance of the suspension was monitored as a function of time, and a decrease in enzymatic activity after immobilization of the enzyme on the polymeric film was observed. The loss of activity could be a consequence of denaturation of the enzyme or of limitations to substrate accessibility. However, growth inhibition reached values similar to those of the free enzyme at the end of the assay.

The EVOH-lysozyme films were applied to reduce the growth of L. monocytogenes without migration of lysozyme from the film. No significant differences were found between the free lysozyme and the EVOH-lysozyme films, probably owing to the amount of immobilized enzyme in direct contact with the microorganism at the film/medium interface. These antimicrobial films have the advantage of not adding preservatives to the food product. 


\section{REFERENCES}

[1] M. Abadias, J. Usall, M. Anguera, C. Solson, I. Vinas, Microbiological quality of fresh, minimally-processed fruit and vegetables, and sprouts from retail establishments, International Journal of Food Microbiology, 123 (2008) 121-129.

[2] S. Burt, Essential oils: their antibacterial properties and potential appliations in foods - a review, International Journal of Food Microbiology, 94 (2004) 223-253.

[3] R. Ahvenainen, New approaches in improving the shelf life of minimally processed fruit and vegetables, Trends in Food Science \& Technology, 7 (1996) 179-187.

[4] M.I. Barriga, G. Trachy, C. Willemot, R.E. Simard, Microbial changes in shredded iceberg lettuce stored under controlled atmospheres Journal of Food Science, 56 (1991) 1586-\&.

[5] S.A. Valencia-Chamorro, L. Palou, M.A. del Rio, M.B. Perez-Gago, Antimicrobial Edible Films and Coatings for Fresh and Minimally Processed Fruits and Vegetables: A Review, Critical Reviews in Food Science and Nutrition, 51 (2011) 872-900.

[6] E. Rodriguez, Seguer J, Rocabayera X, M. A., Cellular effects of monohydrochloride of L-arginine, N-lauroyl ethylester (LAE) on exposure to Salmonella typhimurium and Staphylococcus aureus, Journal of Applied Microbiology, 96 (2004) 903-912.
[7] D.R. Hawkins, X. Rocabayera, S. Ruckman, R. Segret, D. Shaw, Metabolism and pharmacokinetics of ethyl N-alpha-lauroyl-L-arginate hydrochloride in human volunteers, Food and Chemical Toxicology, 47 (2009) 2711-2715.

[8] S. Shima, H. Matsuoka, T. Iwamoto, H. Sakai, Antimicrobial action of epsilon-poly-L-lysine Journal of Antibiotcs., 37 (1984) 1449-1455.

[9] S. Miya, H. Takahashi, T. Ishikawa, T. Fujii, B. Kimura, Risk of Listeria monocytogenes Contamination of Raw Ready-To-Eat Seafood Products Available at Retail Outlets in Japan, Applied and Environmental Microbiology, 76 (2010) 3383-3386.

[10] J.W. Park, Surimi and surimi seafood, CRC Press, Boca Raton, FL, 2014.

[11] R. Amorati, M.C. Foti, L. Valgimigli, Antioxidant Activity of Essential Oils, Journal of Agricultural and Food Chemistry, 61 (2013) 1083510847.

[12] S. Bansal, S. Choudhary, M. Sharma, S.S. Kumar, S. Lohan, V. Bhardwaj, N. Syan, S. Jyoti, Tea: A native source of antimicrobial agents, Food Research International, 53 (2013) 568-584.

[13] J.N. Talbert, J.M. Goddard, Enzymes on material surfaces, Colloids and Surfaces B-Biointerfaces, 93 (2012) 8-19. 



\section{CONCLUSIONS}

1. The experimental studies on the antimicrobial activity of oregano essential oil (OEO), citral, ethyl lauroyl arginate (LAE), epsilon-polylysine (EPL), green tea extract (GTE) and lysozyme demonstrate that all these agents present adequate antimicrobial effect against the selected pathogen microorganisms, and therefore they are well suited to be used as preservatives for the development of active food packaging materials and could be valid alternatives to synthetic food preservatives.

2. Films with different concentration of the antimicrobial agent were successfully manufactured by casting. OEO, citral, LAE, EPL and GTE were added directly to the film forming solution of ethylene vinyl alcohol copolymers (EVOH29 and EVOH44). Functional properties of obtained films were not relevantly affected by the incorporation of the antimicrobial agents. The release of the active agents depended on their affinity for the food simulants that were used and the ability of the simulant to swell the polymer.

3. EVOH films with $\mathrm{OEO}$ and citral presented excellent antimicrobial properties against Listeria monocytogenes, Escherichia coli and Salmonella enterica, being with more activity against the Gram negative. EVOH coated PP films manufactured by casting and by gravure printing at industrial scale were used to pack minimally-processed salad under MAP. All antimicrobial films presented promissing results throughout the storage period of the salad. Indeed, the active-packaged samples recorded lower microbial counts than the control samples, were fresher and their overall quality sensorial acceptability was marked higher and described as having a pleasant flavor.

4. The antimicrobial activity of EVOH29 and EVOH44 films containing LAE were tested against Listeria monocytogenes, Escherichia coli and Salmonella enterica, showing better results against Gram positive bacteria. EVOH29 films presented greater antimicrobial capacity than EVOH44 films due to their higher hydrophilicity and, as a consequence of this, the quicker release of LAE into the tested food simulant. The developed films also reduced the native microflora and the pathogen microorganisms in different food matrixes (infant milk, chicken stock and surimi sticks) extending their shelf life.

5. The release of $\varepsilon$-polylysine from the $\mathrm{EVOH}$ films to an aqueous liquid medium was only partial, being greater from EVOH29 films than from EVOH44. In spite of this limited release, the films inhibited the growth of Escherichia coli and to a large extent Listeria monocytogenes, in that medium. In vivo experiments showed that the active films reduced the microbial loads in surimi sticks at refrigeration temperatures, thus increasing their shelf life.

6. EVOH29 films containing separately or a mixture of OEO and GTE exposed to aqueous simulants presented a partial release which was greater in the simulants with higher ethanol content. Films containing GTE presented the highest antioxidant activity while films containing OEO showed the strongest antimicrobial activity against Listeria mono- 
cytogenes and Escherichia coli. Although the essential oil and the extract presented antimicrobial and antioxidant activity, the combination of GTE and OEO in the films did not result in any synergistic or additive antimicrobial or antioxidant effect.

7. $\mathrm{EVOH}$ (EVOH29 and EVOH44) provided an adequate chemistry (hydroxyl group) for surface modification to introduce desired quantity of reactive functional groups (carboxylic acid group) for the posterior covalent attachment of lysozyme to the functionalized polymer surface.

8. Lyzozyme functionalized EVOH films can be applied to reduce the growth of Gram positive bacteria (L. monocytogenes) without migration of the lysozyme from the film. The immobilized enzyme films retained similar antimicrobial activity to an equivalent amount of free enzyme over a 24 hour incubation period in an aqueous food simulant.

9. Finally, EVOH29 and EVOH44 incorporated with antimicrobial compounds could be applied as an inner coating of a functional packaging structure, releasing the active agent or acting by direct contact, thus, reducing the addition of preservatives to food products. These actions have been shown to provide an effective protection against contamination with a potential increment of the microbiological shelf life of minimally-process salad, infant milk, surimi sticks and chicken stock. In addition, EVOH films could be used to package foods free of preservatives, ensuring their safety even after package opening at home. This packaging technology could be used as an integral part of "Hurdle Technology" in food processing. 

